EDWARD MEIRELLES DE OLIVEIRA

\title{
Sistema Único de Saúde (SUS): contradições determinadas pelo desenvolvimento das forças produtivas da sociedade
}

\author{
Versão corrigida
}

Tese apresentada ao Departamento de Psicologia da Faculdade de Filosofia, Ciências e Letras de Ribeirão Preto da Universidade de São Paulo, como parte dos requisitos para obtenção do grau de Doutor em Ciências.

Área de Concentração: Psicologia

Orientador: Prof. Dr. Marco Antonio de Castro Figueiredo 
Autorizo a reprodução e divulgação total ou parcial deste trabalho, por qualquer meio convencional ou eletrônico, para fins de estudo e pesquisa, desde que citada a fonte.

Oliveira, Edward Meirelles de

Sistema Único de Saúde (SUS): contradições determinadas pelo desenvolvimento das forças produtivas da sociedade. Ribeirão Preto, 2015.

209 p. : il. ; $30 \mathrm{~cm}$

Tese de Doutorado, apresentada à Faculdade de Filosofia, Ciências e Letras de Ribeirão Preto/USP. Área de concentração: Psicologia.

Orientador: Figueiredo, Marco Antonio de Castro.

1. Saúde. 2. Reificação. 3. Intencionalidade. 4. Mercantilização. 
Nome: Oliveira, Edward Meirelles de

Título: Sistema Único de Saúde (SUS): contradições determinadas pelo desenvolvimento das forças produtivas da sociedade.

Tese apresentada ao Departamento de Psicologia da Faculdade de Filosofia, Ciências e Letras de Ribeirão Preto da Universidade de São Paulo para obtenção do título de Doutor em Ciências. Área de Concentração: Psicologia.

Aprovado em:

1

Banca Examinadora

Prof. Dr. (a)

Instituição:

Assinatura:

Prof. Dr. (a)

Instituição:

Assinatura:

Prof. Dr. (a)

Instituição:

Assinatura:

Prof. Dr. (a)

Instituição:

Assinatura:

Prof. Dr. (a)

Instituição: Assinatura: 



\section{DEDICATÓRIA}

Aos meus pais, Célio Rodrigues de Oliveira e Zulena Alves Meirelles, que apesar das dificuldades da vida, me ensinaram os verdadeiros valores do ser humano, fundamentais na direção da solidariedade, responsabilidade pessoal e social.

À Ivonete Helena Rocha, companheira de sonhos, de lutas e de vida, que trouxe para minha existência e para este trabalho, uma cumplicidade amorosa e enriquecedora nas reflexões e nas vivências, contribuindo para nosso devir como pessoas mais inteiras e por uma humanidade mais justa e solidária.

Aos meus interlocutores em cada um dos municípios visitados, sem os quais simplesmente não haveria esta tese. Sem sombra de dúvidas, este trabalho pertence a vocês. Infelizmente, por questões de sigilo ético firmado, não posso agradecê-los nominalmente por todo valioso tempo que lhes tomei.

A toda população brasileira que tem financiado meus estudos. Que os resultados e desdobramentos desta tese possam contribuir para o fortalecimento do SUS como Política Pública de Saúde universal e resolutiva. 



\section{AGRADECIMENTOS}

A DEUS pela minha vida, pela benção de mais esta importante conquista e pela oportunidade de evolução ao lado de pessoas especiais que, com muito amor, me auxiliam a crescer.

Ao professor Dr. Marco Antonio de Castro Figueiredo, querido Marquinho, orientador-amigo e amigo-orientador, com o qual a convivência me impôs transformações. Que com seu jeito permeado de afeto, competência, sensibilidade e segurança, demonstra diariamente que é possível um projeto de trabalho ético e comprometido com qualidade em ensino, pesquisa e extensão, com vistas ao atendimento das necessidades de vida das pessoas. Agradeço a oportunidade de convivência, aprendizado, bem como as perspectivas de parcerias em projetos futuros, contribuindo para nosso devir por uma "síntese necessária".

À $C A P E S$, pelo fomento concedido em forma de bolsa de doutorado.

Aos docentes da pós-graduação e funcionários da Faculdade de Filosofia, Ciências e Letras de Ribeirão Preto, particularmente, aqueles do Departamento de Psicologia, em especial às queridas Jacqueline Corrêa e "Nalinha” Almeida Silva, pelo carinho e amizade.

A todos os funcionários da Casa de Hospedes da Prefeitura do Campus de Ribeirão Preto, pela acolhida, cuidado e carinho, em todos os momentos que necessitei. Em especial, à querida Shirlene Marciano Ingisa.

A todos meus familiares, que sempre me incentivaram e têm acompanhado minha trajetória de vida.

Às queridas Luana Rodrigues de Oliveira Tosta e Elisangela Aparecida Felipe pelo carinho e auxilio nas transcrições das entrevistas e sugestões nas análises.

Aos amigos, Ederson Bisinoto, Flávio J. da Costa, Jéssica S. Veronez, José Brigagão Junior, Juliana Brigagão, Elisangela A. Felipe, Ivana C. Leite Cunha, Cristiano Arantes, Tatiane Mota e a todos os funcionários da Superintendência Municipal de Saúde de Sacramento (gestão 2009-2012) que dividiram comigo, no fazer saúde, intensos momentos de luta, nervosismo, tristeza, anomia, mas também de alegria, superação, esperança, confiança e certeza de missão cumprida. Muito obrigado por me acolherem e acreditar!

À querida amiga, Tânia Maluf, apoiadora COSEMS Uberaba, pela presteza, disponibilidade e solicitude às demandas dos Secretários Municipais de Saúde da região, bem como, às desse estudo. 
Aos amigos sempre presentes: Samuel Sá Marques, Bergson Evangelista dos Santos e Samira Alessandra Reis.

À querida amiga Patricia Magnabosco, hoje Prof. ${ }^{a}$ Dr. $^{a}$ da UFU, com quem teci profícuas parcerias acadêmicas durante o doutorado e expectativas de trabalhos futuros.

Aos membros da banca de qualificação, Prof. ${ }^{a}$ Dr. $^{a}$ Rosana Freitas Arantes e Prof. ${ }^{a}$ Dr. ${ }^{a}$ Maria do Carmo Gullaci Grimarães Caccia-Bava, que aceitaram avaliar meu trabalho e agregaram imenso valor a ele com suas valiosas sugestões e indicações bibliográficas.

Em nome da Prof. ${ }^{a}$ Dr. ${ }^{a}$ Sonia Regina Pasian, agradeço a todos aos membros da Comissão de Bolsas do Programa de Pós-graduação em Psicologia, pelo aprendizado e parceria.

Ao amigo e companheiro, Haroldo da Silva Santana, que com jeito "paraense/mineiro" deu a tônica de movimento na minha vida profissional e em todos os processos envolvidos nos meus trabalhos de mestrado e doutorado.

Aos irmãos, da "Grande Família Marco Antonio", Lícia Barcelos, Lupércio Oliveira, Marina Simões, Rosana Mumic, Ana Alayde Pichelli, Dário Teófilo, Joana Felipa, Bruna Griolli, Cíntia Yuri, Laura Marangoni e Tatiana Garcia, pelo carinho, orientações, amizade, companheirismo e pelas parcerias futuras que espero compor com vocês.

Aos amigos da Pós-graduação, Anelisa Vaz de Carvalho, Gislaine Gasparin Nobile e Leandro Amorim Rosa, pelo carinho com que me acolheram e confiança que sempre depositaram.

A toda Família Figueiredo: Cláudio, Sérgio, Eduardo (Dudu), Henrique, Marcio e, especialmente, à Silvia, pela paciência, principalmente com meu orientador, presteza, disponibilidade, acolhimento, carinho e amizade.

A toda Família Rocha: Dona Neuza, "Zirinho”, Arcisio, Rita, Murilo, “Zaninho”, Dila, Bebel, Gabriel, Deiber e Bruna, pela acolhida, torcida, carinho e paciência na reta final deste trabalho.

À prestativa e cuidadosa Maria Cristina M. Ferreira, funcionária da Biblioteca Central do Campus da USP de Ribeirão Preto, pela revisão e adequação deste trabalho às normas do Programa de Pós-Graduação em Psicologia. 
À Ivonete Helena Rocha e Elisangela Aparecida Felipe, por acolherem minhas angustias na fase final deste trabalho, bem como pelas contribuições críticas e auxílio nas revisões.

Aqui, gostaria de tecer um agradecimento muito especial à Elisangela Aparecida Felipe e a Ivana Candida Leite Cunha, primeiro, por continuarem acreditando e defendendo juntamente comigo que com compromisso pessoal e social o SUS é viável; segundo, por terem me "empurrado" para o doutorado; terceiro, pelo privilégio e oportunidade de ter partilhado com vocês o aprendizado contínuo na luta pela constituição de um serviço público de saúde universal, resolutivo e em defesa da vida dos usuários.

A todos, muito obrigado! 



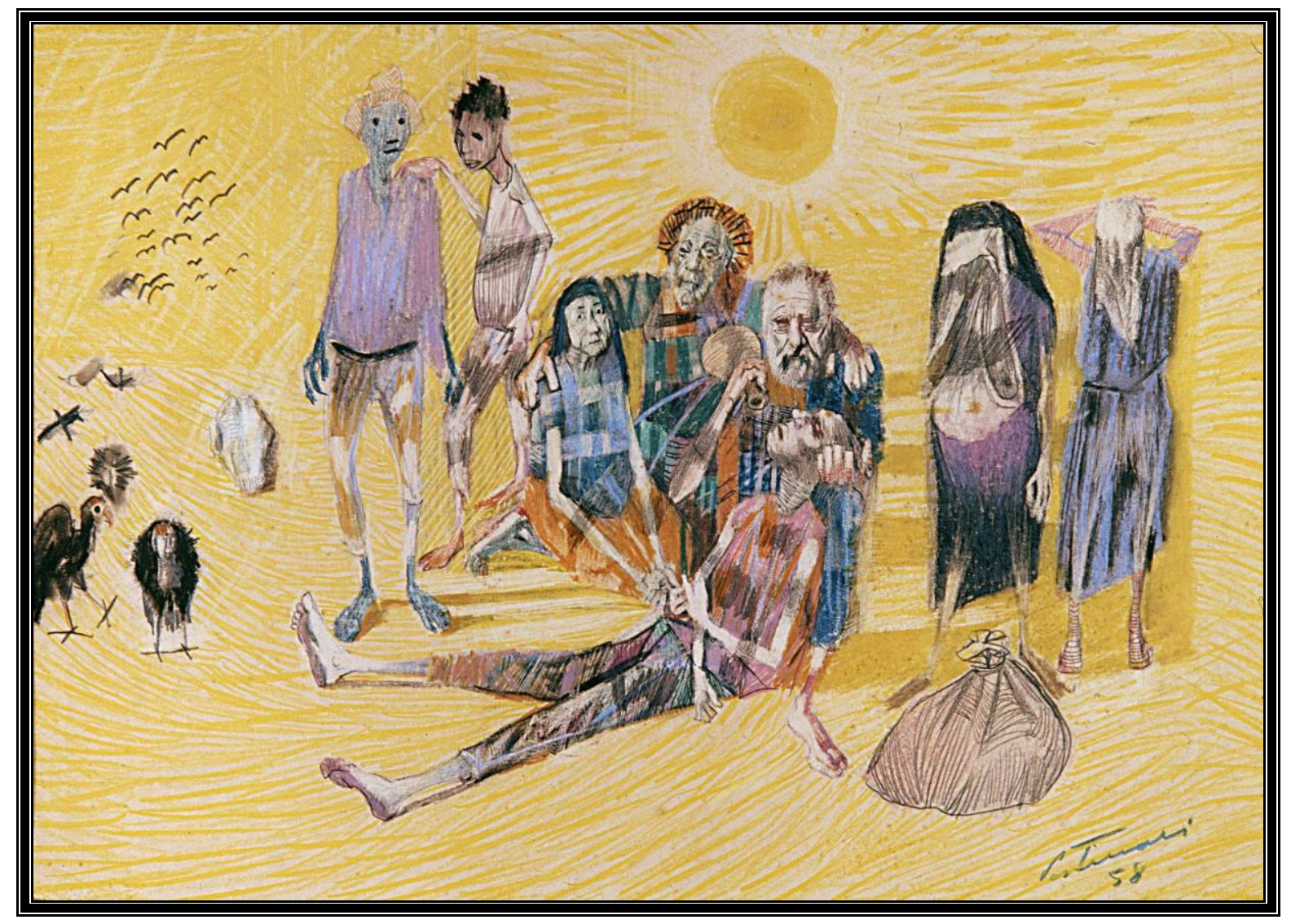

A pintura que ilustra esta tese é Grupo com Homem Doente ${ }^{1}$, do pintor Cândido Portinari (1903-1962), datada de 1958. O artista retratou em suas obras o cotidiano do povo brasileiro, suas condições de vida e trabalho e os problemas sociais do país: questões convergentes com minha tese de doutorado, em que tratarei das contradições determinadas pelas relações sociais de produção ao Sistema Único de Saúde (SUS). Agradeço ao Prof. João Candido Portinari e ao Projeto Portinari pela honra em poder utilizar a imagem desta obra de inegável beleza e expressividade para ilustrar minha tese.

"Estou com os que acham que não há arte neutra. Mesmo sem nenhuma intenção do pintor, o quadro indica sempre um sentido social"

Cândido Portinari

\footnotetext{
${ }^{1}$ Candido Portinari. (1958). Grupo com Homem Doente, FCO: 1689, CR: 4352, Desenho a lápis de cor/papel 27 x $38 \mathrm{~cm}$. Reprodução autorizada por João Candido Portinari (Anexo A). Imagem do acervo do Projeto Portinari. Recuperada em 05 de dezembro de 2014, de http://www.portinari.org.br/\#/acervo/obra/1689
} 

"Uma coisa é pôr ideias arranjadas, outra é lidar com país de pessoas, de carne e sangue, de mil-e-tantas misérias... Tanta gente - dá susto de saber - e nenhum se sossega: todos nascendo, crescendo, se casando, querendo colocação de emprego, comida, saúde, riqueza, ser importante, querendo chuva e negócios bons..."

João Guimarães Rosa, Grande Sertão: Veredas 



\section{RESUMO}

Oliveira, E. M. (2015). Sistema Único de Saúde (SUS): Contradições determinadas pelo desenvolvimento das forças produtivas da sociedade. Tese de Doutorado, Faculdade de Filosofia, Ciências e Letras de Ribeirão Preto, Universidade de São Paulo, Ribeirão Preto, SP.

A naturalização do caráter mercantil da saúde no Brasil possui estreita vinculação com sua história. Antes do Sistema Único de Saúde (SUS), a saúde não era um direito de todos, muito menos uma responsabilidade do Estado e estava restrita a uma parcela da população trabalhadora que pagava para garantir esse benefício. Desde o século passado já se priorizava a saúde privada em detrimento de uma oferta de serviços públicos que abrangesse todas as camadas sociais. Tal fato traduz o processo de reificação e mercantilização da saúde. Esse estudo teve como objetivo analisar os determinantes sócio-históricos mais gerais ligados à questão da saúde como mercadoria e seus reflexos sobre o SUS. A pesquisa foi desenvolvida com 27 participantes, nove secretários de saúde, nove usuários conselheiros municipais de saúde e nove usuários do SUS, distribuídos em nove municípios da Macrorregião Triângulo Sul do estado de Minas Gerais. Para coleta dos dados foram realizadas entrevistas individuais seguindo procedimentos de evocação, enunciação e averiguação. As gravações das entrevistas filmadas ou áudio-gravadas foram transcritas integralmente. A análise das entrevistas foi processada via identificação de conteúdos ex post facto para definição de categorias e unidades temáticas, relacionadas ao processo de reificação da saúde. Tais resultados foram analisados sob a perspectiva do materialismo histórico e dialético. Três categorias temáticas, uma para cada segmento dos entrevistados, agruparam alguns determinantes ligados ao objetivo do trabalho: A) Racionalidades do Sistema Único de Saúde (secretários de saúde), em que foram reunidos conteúdos referentes aos elementos de enfrentamento para a provisão do direito à saúde, apontando racionalidades e intencionalidades que orientam a atuação dos sujeitos no fazer saúde. B) Racionalidades do Controle Social (conselheiros de saúde), relacionada à identificação de processos psicossociais implicados na constituição da identidade com a política pública de saúde e com a memória da luta de classes. C) Relatos de vidas marcadas pela reificação (usuários do SUS), em que os conteúdos referem os conflitos sociais que causam dor, sofrimento e humilhação cotidiana para dezenas de milhões de brasileiros. A análise dos depoimentos nos permitiu identificar que o processo de reificação da saúde pode ser considerado determinante, tanto para a desestruturação do Sistema Único de Saúde, como para a perda da subjetividade e cidadania dos indivíduos. As atividades reificadas em saúde podem ser enfrentadas a partir da formulação de estratégias de organização com a comunidade, cuja síntese realizada com os usuários, permite identificar critérios de enfrentamento com base no cotidiano, dentro do processo saúde/doença.

Palavras-chave: Saúde. Reificação. Intencionalidade. Mercantilização. 



\begin{abstract}
Oliveira, E. M. (2015). Unified Health System (SUS): Contradictions determined by the development of the productive forces of society. Tese de Doutorado, Faculdade de Filosofia, Ciências e Letras de Ribeirão Preto, Universidade de São Paulo, Ribeirão Preto, SP.
\end{abstract}

The naturalization of the mercantile character of health in Brazil has close ties with its history. Before the Unified Health System (SUS), health was not a right for everyone, let alone a state responsibility and was restricted to a portion of the working population that paid to ensure that benefit. Since the last century the private health is prioritized at the expense of a public service offering covering all social strata. This fact reflects the process of reification and commodification of health. This study aimed to analyze the broader socio-historical factors linked to the issue of health as a commodity and its impact on the SUS. The research was conducted with 27 participants, nine health secretaries, nine municipal health counselors users and nine SUS users, distributed in nine municipalities of the Macroregion South Triangle of Minas Gerais. For data collection were carried out individual interviews following evocation procedures, enunciation and verification. Recordings of filmed or audio-recorded interviews were transcribed in full. Data analysis was processed by the ex post facto content identification for the definition of categories and topics related to the process of reification of health. These results were analyzed from the perspective of historical and dialectical materialism. Three themes, one for each segment of respondents, grouped some determinants linked to the objective of the study: A) rationalities of the Unified Health System (health secretaries), in which contents have been gathered regarding the coping elements for the provision of the right to health, pointing rationality and intentions that guide the actions of individuals in making health. B) rationalities of social control (health counselors), related to identification of psychosocial processes involved in the formation of identity with the public health policy and with the memory of the class struggle. C) Reports of lives marked by reification (SUS users), in which the contents related social conflicts that cause pain, suffering and daily humiliation to tens of millions of Brazilians. The analysis of testimonies allowed us to identify that the health reification process can be considered decisive for both the disruption of the SUS, as for the loss of subjectivity and citizenship of individuals. The reified in health activities can be addressed from the formulation of organizational strategies with the community, whose synthesis performed with users, identifies coping criteria based on the daily life within the health/disease process.

Keywords: Health. Reification. Intentionality. Commodification. 



\section{LISTA DE FIGURAS}

Figura 1 - Mapa da Macrorregião assistencial Triângulo Sul e respectivas Microrregiões

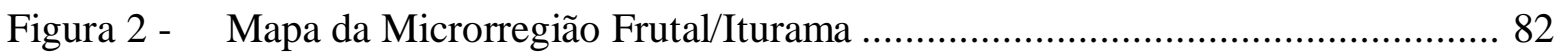

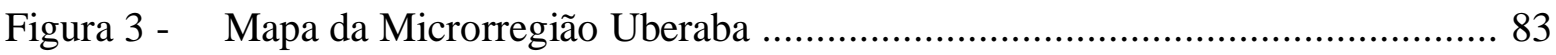

Figura 4 - $\quad$ Mapa da Microrregião Araxá ….................................................................... 83

Figura 5 - $\quad$ Mapa de localização dos municípios selecionados para o estudo ................... 84

Figura 6 - Organograma de distribuição dos sujeitos participantes do estudo por município, Microrregião e segmento que representam

Figura 7 - Quadro de etapas dos procedimentos de Análise de Conteúdo do Material transcrito nas entrevistas

Figura 8 - Perfil sociodemográfico dos secretários de saúde participantes do estudo

Figura 9 - Organograma demonstrativo das unidades temáticas da Categoria 1 - Racionalidades do SUS

Figura 10 - Perfil sociodemográfico dos usuários conselheiros participantes do estudo

Figura 11 - Organograma demonstrativo das unidades temáticas da Categoria 2 - Racionalidades do Controle Social

Figura 12 - Perfil sociodemográfico dos usuários participantes do estudo. 148 



\section{LISTA DE TABELAS}

Tabela 1 - População residente estimada por municípios, microrregiões e Macrorregião Triângulo Sul, Minas Gerais, 2014

Tabela 2 - Cobertura da Estratégia Saúde da Família (ESF) e População SUS Dependente nos municípios participantes do estudo, Minas Gerais, 2010 87

Tabela 3 - Estrutura de Saúde da Família implantada e Teto para implementação/credenciamento de equipes na APS em cada município participante do estudo, Minas Gerais, 2010.

Tabela 4 - Distribuição dos Leitos Hospitalares e Complementares em cada município participante do estudo, Minas Gerais, 2015

Tabela 5 - Número de médicos cadastrados no Cadastro Nacional de Estabelecimentos de Saúde (CNES) para cada município participante do estudo, Minas Gerais, 2015

Tabela 6 - Demandas judiciais da Macrorregião Triângulo Sul atendidas pelo Núcleo de Redes de Atenção à Saúde, Minas Gerais, 2013 



\section{SUMÁRIO}

INTRODUÇÃO 25

CAPÍTULO 1 - REIFICAÇÃO E SAÚDE 39

1.1. O processo de reificação da saúde: coisificação global da vida. 41

1.2. O mercado: pretensão de caminho exclusivo e universal ...... 48

1.3. A saúde como mercadoria: de elemento da vida humana a produto que deve ser consumido no mercado 51

1.4. Direito à Saúde no Brasil: fetiche frente a prevalência da lógica do mercado

CAPÍTULO 2 - PERCURSO METODOLÓGICO 77

2.1. Caracterização do estudo ....................................................................................... 79

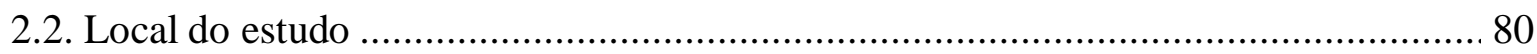

2.2.1. Algumas características dos serviços de saúde dos municípios participantes e da Macrorregião .................................................................... 86

2.3. Os participantes do estudo ............................................................................... 91

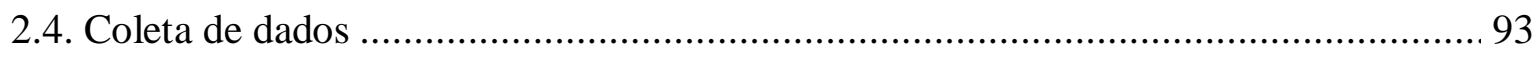

2.4.1. A realização do trabalho de campo .................................................................... 95

2.5. Questões éticas para realização do estudo .................................................................. 98

2.6. Análise de conteúdo e tratamento dos dados ........................................................... 98

CAPÍTULO 3 - RESULTADOS E REFLEX̃̃ES..................................................... 103

3.1. Perspectivas apontadas por Secretários Municipais de Saúde

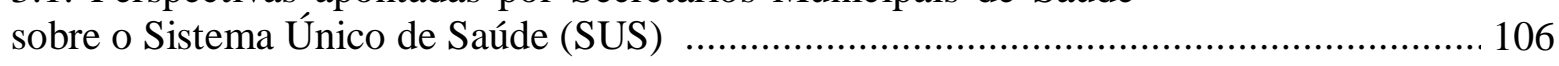

3.1.1. Caracterização dos Secretários Municipais de Saúde (Gestores do SUS) ............... 106

3.1.2. Categoria 1 - Racionalidades do Sistema Único de Saúde ...................................... 109

3.1.2.1. Universalidade Regulada ........................................................................... 110

3.1.2.2. Desigualdade Social via Dicotomia Público/Privado .......................................... 118

3.1.2.3. Judicialização da Saúde: "Desigualdade injusta" ................................................. 126

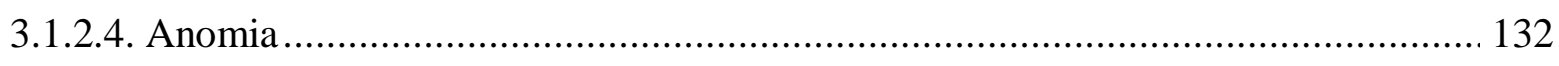

3.2. Perspectivas apontadas pelos usuários Conselheiros Municipais de Saúde sobre o Sistema Único de Saúde (SUS) ......................................... 136

3.2.1. Caracterização sociodemográfica dos Conselheiros Municipais de Saúde (Representantes dos Usuários) ………………………………...... 136 
3.2.2. Categoria 2 - Racionalidades do Controle Social ................................................ 138

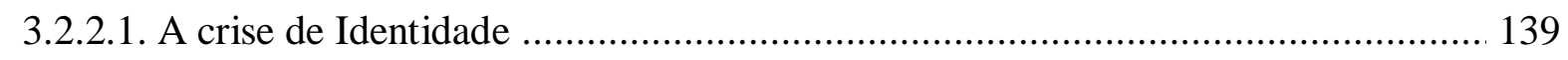

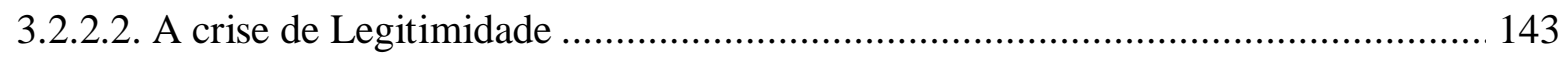

3.3. Perspectivas apontadas pelos Usuários sobre o Sistema Único de Saúde (SUS) ........ 147

3.3.1. Caracterização sociodemográfica dos Usuários .................................................. 147

3.3.2. Categoria 3 - Relatos de vidas marcadas pela reificação ....................................... 149

ALGUMAS CONSIDERAÇÕES FINAIS.......................................................... 155

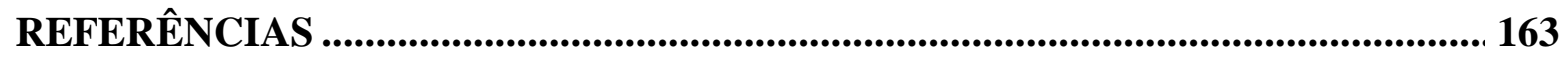

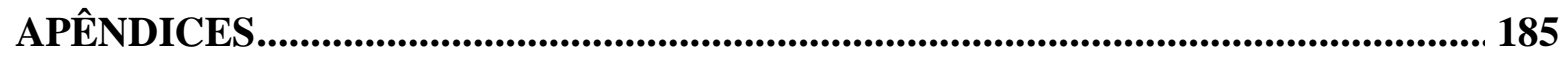

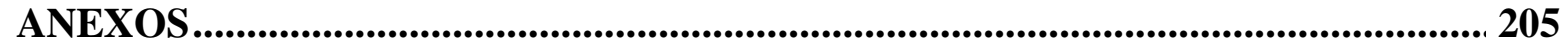


INTRODUÇÃO 



\title{
O despertar para o problema: na primeira pessoa do singular.
}

\author{
"Vamos bordando a nossa vida, sem conhecer \\ por inteiro o risco; representamos o nosso papel, \\ sem conhecer por inteiro a peça. De vez em \\ quando, voltamos a olhar para o bordado já feito \\ e sob ele desvendamos o risco desconhecido; ou \\ para as cenas já representadas, e lemos o texto, \\ antes ignorado. E é então que se pode escrever - \\ como agora faço - a 'história',” ...
}

Magda Soares, Metamemória-memórias: travessia de uma educadora

Essa pesquisa enquadra-se no campo de estudos da saúde coletiva e objetiva analisar os determinantes sócio-históricos mais gerais ligados à saúde como mercadoria e os reflexos dessa racionalidade sob o Sistema Único de Saúde.

Não tenho dúvidas de que o que somos seja resultado de nossa práxis, na qual provamos a verdade, nos encontramos e atuamos enquanto sujeitos históricos do tipo "que, de vez em quando, volta a olhar para o bordado já feito e sob ele desvenda o risco desconhecido" sobre as ideias e a realidade. Por conseguinte, a atuação em saúde exige não só uma boa formação teórica, mas também a vivência. A vivência pode significar a afirmação ou negação do processo formativo para se atuar em saúde e/ou subsidiar novos referenciais, os quais esperamos que sejam no sentido de se aproveitar a aprendizagem informal, acumulada pela experiência no cuidado com os pacientes/usuários.

Antes de tudo esta tese tem relação direta com minha dissertação de mestrado (E.M. Oliveira, 2009), estudo em que abordamos os determinantes sócio-históricos do cuidado na Estratégia Saúde da Família sob a perspectiva de usuários da área rural. Se no mestrado o tema da dissertação foi abordado sem uma maior compreensão das categorias da "crítica da economia política" enunciada pela tradição marxista, nesta tese procurou-se utilizar algumas dessas categorias para elaborar uma crítica à prática em saúde subordinada de forma direta às relações de produção e fundamentada na determinação das relações reificadas da ordem do capital. 
Desta forma, imaginar-se-ia que esta tese fosse fruto do aprofundamento do estudo que teve início no mestrado, mas é muito mais do que isso, pois se trata de uma tentativa de sistematizar inquietações impostas por todo um conjunto de relações sociais de produção, que no campo da saúde pode ser sentida por qualquer pessoa da nossa sociedade.

O trabalho que ora iniciamos fundamenta-se na síntese de vivências realizadas no plano da saúde, enquanto enfermeiro, na coordenação da Seção de Vigilância Epidemiológica, como membro de uma Equipe da Estratégia Saúde da Família Rural e, ainda, como Secretário de Saúde de uma pequena cidade no interior do estado de Minas Gerais. Nessa perspectiva, interessa recuperar um pouco da trajetória profissional que me levou a desenvolver este estudo, assinalando algumas noções reificadas presentes neste processo, não sem antes destacar aos leitores a impossibilidade de expressar em detalhes, na exposição aqui apresentada, todas as relações sociais presentes nestas vivências realizadas no plano da saúde.

Em 2003, após ter sido aprovado em concurso público, assumi no município de Sacramento/MG, minha terra natal, a função de Coordenador da Seção de Vigilância Epidemiológica. Com muita disposição para iniciar minha vida profissional fui acolhido e apadrinhado pela querida Isabel dos Reis Camargo, naquela época, enfermeira e gestora do Sistema Único de Saúde (SUS) daquela cidade, que me atribuiu total autonomia e confiança para recomeçar um trabalho de reestruturação da Seção de Vigilância Epidemiológica. Trabalho este iniciado por outra enfermeira, Ivana Candida Leite da Cunha, que naquele momento estava encarregada da estruturação do serviço de Saúde Mental no município, ambas, exemplo de profissionalismo e competência técnica, com quem teci minhas primeiras parcerias em minha vida profissional. Aqui não posso deixar de citar dois grandes amigos e apoiadores na tarefa de reestruturação da vigilância, o educador em saúde Bergson Evangelista dos Santos e a fiscal sanitária, Diolinda Maria Pereira; graças a eles o nosso trabalho frente à Vigilância Epidemiológica de Sacramento foi reconhecido, por três anos consecutivos, pela antiga Diretoria Regional de Saúde (DRS) de Uberaba.

A atuação na Seção de Vigilância Epidemiológica me colocaria, já bem no início da minha vida profissional, diante de inquietações que me acompanham desde então e que, creio eu, me acompanharão por toda minha vida profissional e pessoal.

Para exemplificar algumas dessas inquietações podemos citar a prevalente naturalização biomédica da doença como objeto - objetivo - das ações de vigilância epidemiológica, quase sempre não levando em consideração os determinantes sócio-históricos do processo saúde/doença. Tal naturalização oculta os processos que constituem os problemas de saúde e determina uma ação policialesca/reducionista de "controlar" e quantificar doenças, 
óbitos e agravos de notificação compulsória, com foco na composição de mapas, consolidados e relatórios ao final de cada semana epidemiológica, mês ou ano.

Outro tipo de problema particularmente inquietante, vivenciado no período em que trabalhei na Seção de Vigilância Epidemiológica, foi o reforço de processos de discriminação e estigmatização social de sujeitos "identificados" ou "supostamente identificados" nas categorizações acerca do HIV/AIDS. Infelizmente naquele período tive que conviver e lutar contra insistente solicitação de um grupo de dentistas do serviço de saúde que acreditavam que eu era obrigado a oferecer-lhes uma lista de nomes de "pacientes" com "HIV/AIDS" para que eles pudessem se "proteger".

Neste contexto, havia também alguns profissionais médicos que acreditavam que a partir da sorologia positiva qualquer atendimento ou tratamento que estes pacientes necessitassem deveriam ocorrer apenas no município de referência terciária, ou seja, na cidade de Uberaba a $78 \mathrm{~km}$ da residência dos pacientes. Como disse um desses profissionais médicos ao dar o diagnóstico positivo do primeiro exame (denominado de Elisa) a uma gestante: "a partir de agora minha filha! Eu não lhe ponho mais a mão, seu tratamento é todo em Uberaba".

Uma análise, hoje, um pouco mais madura demonstra, a meu ver, que um conjunto de reificações orientadas pelo capital se encontram na base destas inquietações e das futuras que apresentarei nesta introdução. Sem avançar, por hora, no detalhamento desta dimensão da saúde reificada, diremos apenas que estas inquietações se tratam de reificações uma vez que ocultam as relações sociais e representam a determinação dos fenômenos econômicos sobre o enfrentamento do processo saúde/doença, sobre os corpos enfermos ou saudáveis, sobre o conhecimento científico e etc. Na saúde reificada o ser humano (também reificado) apresentase como objeto físico privado de qualidades pessoais ou individuais, torna-se coisa, reifica-se. Transforma-se em uma mercadoria.

Por sorte, e indispensáveis ao enfrentamento dessas inquietações/reificações vivenciadas por mim no início de minha vida profissional, em 2003, vieram trabalhar em Sacramento dois outros profissionais, da mesma forma que eu, com muito entusiasmo e mil ideias na cabeça. Um era o Dr. Haroldo da Silva Santana, médico, com várias experiências comunitárias em seu currículo, que experimentava e me permitiu experimentar a saúde como define Wong-Un (2002), "uma forma de criação poética, uma transcendência e uma oportunidade constante de aprendizados metarracionais". Santana, impulsionado por conhecimento e intuições, faz do seu atuar profissional como médico o exercício terno da 
criação de emoções positivas e conhecimentos engajados junto aos denominados "Outros Comunitários", tão diversos, tão ricos e tão pouco reconhecidos.

A outra profissional era Elisangela Aparecida Felipe, assistente social, que se tornou uma grande amiga e companheira de luta no Conselho Municipal de Saúde de Sacramento. Com seu conhecimento e empenho pelas causas sociais, me ofereceu uma visão mais abrangente, inspirada em uma atuação em nível dos determinantes da saúde ou determinantes de vida das pessoas, me enriqueceu e me permitiu um distanciamento da arrogância do saber biomédico, apesar de muitas e constantes recaídas.

Com esses dois profissionais mais que uma parceria, construímos uma aliança, nosso primeiro trabalho em conjunto foi uma análise do perfil de saúde baseado no Sistema de Informações sobre Mortalidade em Sacramento. Surgiu, então, a ideia da constituição de um grupo de estudos, onde uma vez por semana nos reuníamos para estudar e discutir outros trabalhos e temas relacionados à sociologia, antropologia, ciências sociais, etc.

Logo em seguida, Santana assumiu a sua função como médico da Estratégia Saúde da Família (ESF) rural, afinal esse era o propósito da gestão municipal ao trazê-lo para Sacramento. Após o reconhecimento da área e microáreas que compunham a ESF rural, Santana nos propôs um trabalho a exemplo do "Saúde no Mato", projeto executado em Carbonita/MG, que se iniciou quando ele atuava como médico naquela cidade. O "Saúde no Mato" consistia na ida dos alunos do Internato em Saúde Coletiva da Faculdade de Ciências Médicas de Minas Gerais (FCMMG), também conhecido como Internato Rural, para determinada comunidade rural e lá permanecendo por 3 a 6 dias, visitando todos os domicílios da comunidade e promovendo assistência à saúde aos que encontravam.

Sem dúvidas, Elisangela e eu aceitamos prontamente o desafio e dessa forma, mas com uma formatação diferente, surgiu a "Vivência Rural". Naquele primeiro momento contávamos com o apoio de Jaqueline Demeterco, enfermeira da equipe rural da ESF, mas que por suas razões não permaneceu conosco nas atividades da zona rural e passou a atender em uma das equipes urbanas da ESF. Para seu lugar, aprovada em concurso público, assumiu a enfermeira Samira Alessandra Reis. Com ela, formamos o que alguns apelidaram de "Quarteto Fantástico" - com bastante exagero, é claro! Vale destacar que Samira se mostrou, além de grande amiga e companheira nesta caminhada, mais um exemplo memorável de competência técnica, de amor à profissão, aos usuários do SUS e ao próprio SUS.

Mas, para o que estava por vir, faltava o tempero especial e esse nos foi dado pelo empenho e aliança com as agentes comunitárias de saúde que conseguiram fazer com que as comunidades rurais, em número de seis, coincidentes com as microáreas, nos reconhecessem 
como iguais. Com certeza, sem Dona Maria Graças Silva, Sandra Santana, Vicentina, Ana Maria, Dona Maria Batista Araújo, Lúcia Delgado e Rosana Silva a "Vivência Rural" não teria acontecido.

Na Vivência Rural, a equipe da ESF visitava todas as casas, percorrendo a pé e pernoitando nas comunidades de Santa Bárbara, Bananal, Quenta Sol, Jaguarinha, Desemboque e Sete Voltas, convivendo em cada comunidade por três a sete dias. Tratava-se de manter corações e mentes abertos à realidade, dispostos a entender, a partir da reflexão e do debate interno à equipe, mas também da interação e da discussão com a comunidade, o modo de andar a vida daquelas pessoas e a relação com o adoecer.

Nas visitas, a conversa abordava a vida da família, os afazeres diários e suas dificuldades, as expectativas sobre o futuro, a situação social e a de saúde das pessoas da casa. A conversa era conduzida por qualquer um dos profissionais ou às vezes por todos, como em uma conversa habitual. A ideia principal era conhecer todas as famílias, o ambiente doméstico e de trabalho, as relações sociais e o espaço geográfico para prover uma assistência à saúde de forma mais adequada e humanizada, rompendo, pelo menos em parte, com as reificações do cuidado em saúde.

Na Vivência, por meio da "Agenda da Saúde", buscava-se democratizar o espaço público com incentivo ao exercício do controle social dos serviços públicos e a construção de sujeitos com responsabilidade social, enquanto coletividade organizada na luta por seus direitos. A equipe considerava não somente os grupos institucionalmente organizados, mas buscava também compreender o universo simbólico dos grupos sociais que compunham a população rural. A “Agenda” era elaborada em reunião com a comunidade e composta por demandas suscitadas pelos moradores, que posteriormente eram apresentadas ao Poder Público para as providências necessárias, sendo acompanhada pela comunidade organizada em associações comunitárias.

A atuação na Vivência demandou um enorme esforço por parte de toda a equipe de saúde: médico, enfermeiros, assistente social, auxiliares de enfermagem e agentes comunitários, posto que os limites de nossas formações não concebem o cotidiano das pessoas com suas linhas de fuga, reificações e relações com a saúde, como elemento na atuação das equipes. A voz, o espaço de expressão e a ação conjunta com os usuários abriu a oportunidade para a elaboração de novas prioridades, como a busca por uma compreensão mais integrada das necessidades humanas, com seus desdobramentos familiares e comunitários.

Como no trabalho de Rozemberg e Minayo (2001), observamos que as expectativas iniciais de diagnóstico e intervenções puramente biomédicas foram modificadas ao longo do 
processo de atendimento da equipe que tinha a função terapêutica de ampliar a compreensão da experiência para além dos limites da "objetivação científica" ou, de acordo com nosso referencial teórico, “das relações sociais reificadas na sociedade contemporânea”.

Dessa forma constatamos que, em muitos momentos, os processos de "aquisição" da saúde acabavam tendo seus pontos de resolução em outros níveis como: na Previdência Social (INSS); nas parcerias com o Sindicato Rural e EMATER; nos programas Minas Sem Fome e Luz Para Todos; nas Secretarias de Assistência Social, Agricultura e Obras, respectivamente com a conquista de benefícios como: o Benefício de Prestação Continuada (BPC) ${ }^{2}$, na disponibilidade de tratores para o arado da terra, na construção e reforma de casas para prevenção do barbeiro transmissor da doença de chagas, na manutenção das estradas, pontes e mata-burros; na reativação das Associações Comunitárias; na participação tanto da equipe quanto dos usuários nos Conselhos de Saúde, de Assistência Social, da Criança e do Adolescente e de Desenvolvimento Rural ou até mesmo no Poder Judiciário.

Os resultados deste trabalho não demoraram a aparecer! Além de reconhecido pela população o trabalho foi duas vezes premiado, uma pelo Polo de Capacitação Permanente da Universidade Federal de Minas Gerais (UFMG), com o prêmio de Qualidade na Atenção Básica e outra pelo Ministério da Saúde com o prêmio David Capistrano, da política nacional de Humanização do SUS, este último, destinando 50.000 reais à Secretaria de Saúde de Sacramento para investimentos na Vivência Rural.

Infelizmente, toda esta nossa atuação na Vivência acabou nos tornando visíveis, inclusive, em um ambiente que nós não frequentávamos, o da política partidária. Em 2005, instaurou-se pelo candidato vencedor das eleições realizadas no ano anterior, um processo de desmobilização do trabalho e perseguição dos profissionais, o que nos levou (Elisangela, Samira, Santana e eu), um ano após a posse deste prefeito, ou seja, no final do ano de 2005, a pedirmos demissão de nossos cargos e seguir novos caminhos fora de Sacramento.

Particularmente, comecei a ministrar aulas para o curso de enfermagem no Centro Universitário do Planalto de Araxá, a 78 km de Sacramento, concomitantemente Santana e eu ingressamos no mestrado, ele no Departamento de Medicina Social da Faculdade de Medicina de Ribeirão Preto - USP e eu no Departamento de Psicologia e Educação da Faculdade de Filosofia Ciências e Letras de Ribeirão Preto da mesma instituição, sob os cuidados zelosos

\footnotetext{
${ }^{2}$ O BPC é um benefício da Assistência Social que foi instituído pela Lei Orgânica da Assistência Social LOAS. Desvinculado de contribuição à Previdência Social, trata - se do pagamento de um salário mínimo a idosos acima de 65 anos e a pessoas portadoras de deficiência física ou mental, que não tenham condições de prover sua própria subsistência ou de tê-la provida por sua família.
} 
do Professor Dr. Marco Antonio de Castro Figueiredo, querido Marquinho, quem havíamos conhecido durante o desenvolvimento dos trabalhos da Vivência Rural.

Em nossas dissertações, Santana e eu optamos por trabalhar com os moradores da zona rural de Sacramento que haviam participado da Vivência Rural e que reivindicavam a continuidade daquele trabalho. Tal situação nos levou, agora sim, a frequentar e atuar no ambiente da política partidária de Sacramento. Nesse sentido, filiei-me ao Partido Verde (PV) que apoiou o candidato do Partido do Movimento Democrático Brasileiro (PMDB), que poucos meses antes das eleições de outubro de 2008 contava apenas com 9\% das intenções de votos, mas que, em campanha memorável, deslocara as oligarquias que se revezavam no poder local havia décadas.

Neste processo participei ativamente como candidato a vereador, apoiado por Santana, Elisangela, Samira, Patricia Magnabosco e Ivana. Não ganhei como vereador, mas após as eleições fui convidado a assumir a Secretaria Municipal de Saúde de Sacramento, trabalho que iniciei dia primeiro de janeiro de 2009, juntamente com a ansiedade em terminar meu mestrado e em relação aos desafios que estavam por vir. É claro que para essa empreitada convidei Santana, Samira, Elisangela e Ivana, mas por motivos diversos, apenas Elisangela e Ivana aceitaram. Assim, iniciamos nossa gestão com muitas expectativas e esperanças, objetivando a "revitalização" da ESF e o fortalecimento da Atenção Primária a Saúde na cidade de Sacramento.

Foi no interior do trabalho como gestor do SUS que afloraram de maneira contundente inquietações, dúvidas e contradições que levaram a este ensaio. Contar com detalhes as histórias de todas as relações sociais presentes na vivência da gestão da saúde em Sacramento no período de 2009 a 2011 não seria possível. Desta maneira, apresentarei, aos leitores, algumas dificuldades e desafios da gestão do SUS, expressões da triste relação social que perpassa a política pública de saúde subordinada de forma direta às relações de produção ${ }^{3}$, onde tudo é mercadoria.

\footnotetext{
${ }^{3} \mathrm{O}$ materialismo histórico define relações de produção como as relações que se estabelecem entre proprietários dos meios de produção e os produtores diretos em um processo de produção determinado. Tais relações podem ser mútuas de cooperação, de submissão ou de um tipo de relações que signifique transição entre as formas assinaladas. Ou seja, são os vínculos que se estabelecem entre os homens na produção e reprodução da vida material. As relações de produção não podem ser separadas das forças produtivas, que são todas as forças que resultam da combinação dos elementos do processo de trabalho sob relações de produção determinadas. As relações de produção e as forças produtivas existem conjuntamente em indissolúvel unidade e formam, em conjunto, o modo de produção (Hahn \& Kosing, 1983; Triviños, 1987). Desta forma, a compreensão marxiana da sociedade e de suas transformações é feita tomando-se por base a dinâmica das relações materiais. Como afirma Marx, 1982 (citado por Hahn \& Kosing, 1983): "na produção social da sua vida, os homens entram em determinadas relações, necessária, independentes da sua vontade, relações de produção que correspondem a uma determinada etapa de desenvolvimento das suas forças produtivas materiais. A totalidade destas relações
} 
A primeira das dificuldades a ser enfrentada pela nossa equipe gestora foi promover uma luta constante e, em vários momentos, uma ruptura da ideia naturalizada de saúde voltada para atender aos anseios políticos, fosse dos vereadores, do prefeito, de outros secretários municipais, de deputados, dos empresários que haviam financiado as campanhas dos candidatos "vitoriosos" e até mesmo da população. Sem sombra de dúvidas esta ideia de gestão casuística da saúde foi um dos nossos grandes problemas no ano de 2009 e em menor intensidade, mas não menos importante, um problema constante durante toda a gestão.

A demagogia e promiscuidade na barganha pelo voto, tanto por parte de grande número de candidatos, quanto por parte de muitos eleitores, é algo no mínimo absurdo. Como tudo na ordem do capital reifica-se e vira mercadoria, nas eleições de 2008, os candidatos que ofereceram alguma vantagem antes das eleições e/ou algo para após as eleições (como exames, medicamentos, cirurgias, encaminhamentos, etc.), queriam, naquele momento, uma vez eleitos, "pagar" suas promessas. Para isso, procuravam a secretaria municipal de saúde com maços de receitas médicas e pedidos de exames, solicitando liberação/autorização dos mesmos.

Não havia distinção entre serviço público ou privado na origem dos pedidos e os mesmos eram diversificados como por exemplo: cintilografia de corpo inteiro para fazer check up médico, cirurgias plásticas, histerectomias, cirurgias de cataratas, medicamentos fornecidos ou não pelo SUS, exames diagnósticos para os mais variados tipos de doenças, etc.

Minha equipe e eu estávamos decididos a não ceder a esta gestão casuística naturalizada. Com o apoio dos profissionais da Secretaria de Saúde e do Conselho Municipal de Saúde, respondíamos tecnicamente a todas essas demandas políticas. A orientação era a mesma: todos que quisessem utilizar o SUS deveriam passar por consulta na ESF de seu bairro para avaliação ou reavaliação do médico, acompanhamento, tratamento e seguimento do fluxo conforme princípios do SUS. Deixávamos sempre claro aos usuários que eles não precisavam de intermediários para exercerem seu direito à saúde. Desta forma fazíamos frente à prática da gestão casuística e proporcionávamos ênfase no papel coordenador da ESF na formatação da Rede Assistencial de Saúde do município.

Sem dúvidas mexemos em um vespeiro, não agradei meus pares, prefeito, vereadores, secretários e parcela da população que esperava recompensa pelo seu voto. Paguei este preço, jurídica e política, e à qual correspondem determinadas formas de consciência social. O modo de produção da vida material é que condiciona o processo de vida social, política e espiritual” (p. 136). 
mas acredito que foi menos caro para mim do que para os outros, especialmente minha família e amigos mais próximos. Em consequência fui convocado, mais de uma vez, a dar explicações ao plenário da Câmara Municipal de Sacramento e nesta casa avaliado como muito técnico e pouco político (na minha opinião um elogio). Pelo prefeito e outros secretários fui "acusado" de não ser "companheiro". Acredito que naquele momento só não fui retirado do cargo por falta de substituto. Entretanto, as críticas arrefeceram quando os serviços começaram a funcionar adequadamente, as queixas dos usuários reduziram e a saúde do município começou a ser bem avaliada nas avaliações da Secretaria de Estado, do Ministério da Saúde por meio do Programa Nacional de Melhoria do Acesso e da Qualidade da Atenção Básica (PMAQ) e pelo Índice FIRJAN de Desenvolvimento Municipal (IFDM).

Outro grande problema enfrentado por nossa gestão foi a dificuldade em contratar profissionais médicos, tanto para os plantões no Pronto Atendimento da Santa Casa, quanto para a ESF, especialmente para a equipe que realizava os atendimentos na área rural. Eram, e ainda são, vários os fatores para esta dificuldade que, dentre outros, podemos citar: a indisponibilidade de médicos generalistas no mercado de trabalho de maneira geral e em maior proporção nos períodos em que ocorrem as provas para as residências médicas; a “subvalorização" para o mercado médico das residências em Saúde da Família ou áreas afins; a incapacidade financeira e jurídica do município para pagar o valor de mercado ou para atender exigências feitas por alguns destes profissionais no momento da contratação, como redução da carga horária para estudos ou pagamento de aluguel (o que poderíamos chamar de auxílio moradia); a concorrência ou o leilão entre os municípios para conseguir este profissional, ou seja, "quem pagar mais leva" e desta forma os munícios mais pobres não conseguem este profissional ou os perdem para os municípios mais ricos, os quais acabam "gastando/investindo" cada vez mais para manter esses profissionais em seus territórios; por fim, em nossa opinião, a mais importante das dificuldades e fundamental para a alta rotatividade deste profissional, destacamos a ausência de um plano nacional de cargo, carreira e salários e a prevalência de contratos precários no exercício da função.

Nogueira (2010) relata que a pressão pela contratação de médicos e a falta deste profissional para o mercado de trabalho vem acarretando um custo de legalidade administrativa. $\mathrm{O}$ autor ainda destaca que mais de $50 \%$ dos recursos humanos da estratégia de saúde da família são mantidos mediante contratos precários e que em municípios de pequeno e médio porte, a fim de serem atraídos e mantidos em seus postos de trabalhos, os médicos costumam receber remuneração que supera a do prefeito. Dois fenômenos que caracterizam situações irregulares. 
Infelizmente para "resolver" esse problema, garantir a assistência médica e manter salários que superem o do prefeito, Sacramento não foi exceção e como tantos outros municípios fomos "obrigados" a licitar uma cooperativa médica para prestar serviços.

Desde 2002/2003, um grupo de médicos residentes na cidade insistem em atuar como autônomos de uma cooperativa profissional, não participando de concursos ou processos seletivos realizados pela prefeitura (uma vez que os salários via concurso são muito inferiores aos da cooperativa). Tal fato, vem, "historicamente" na cidade, obrigando os prefeitos a abrir um processo de licitação para contratação de cooperativa profissional que oferte a melhor proposta para prestação dos serviços médicos nas diversas especialidades. Como via de regra nunca houve outras cooperativas concorrentes no certame, esta cooperativa dos médicos residentes na cidade de Sacramento vem prestando serviços desde então.

Nessa perspectiva, como alerta Menicucci (2010), a política assistencial, em vez de expandir a rede pública, acolheu os interesses da cooperativa médica ao privilegiar a prestação privada dos serviços, mesmo com a responsabilidade e o financiamento públicos. Nesse sentido, a ação governamental se tornou instrumental aos interesses capitalistas, condicionada às preferências das classes dominantes, ou, em outras palavras, voltada para abrigar os interesses capitalistas do setor. Para a mesma autora, vista como uma atividade econômica, a produção de serviços torna-se, com a ação estatal, um espaço importante para a acumulação capitalista, pela integração entre o Complexo Médico Industrial Financeiro e o Estado.

Nesse contexto, dentre muitas outras, ainda podemos destacar como dificuldades vivenciadas na gestão do SUS Sacramento: a questão dos planos de saúde que invadem os serviços públicos, com a criação da dupla porta de entrada; a intensa judicialização da saúde por pessoas que utilizam o sistema de desembolso direto e/ou que são detentores de planos de saúde em busca de serviços "complementares" aos serviços de seus planos privados; a intensa judicialização da saúde estimulada por grupos econômicos da região e direcionada à incorporação de tecnologias no SUS; a grande dificuldade em operar os parâmetros assistências da Programação Pactuada Integrada (PPI) diante a insuficiência de recursos financeiros e também da Rede Assistencial própria ou prestadora de serviços na região, bem como pelas deficiências no Sistema de Regulação.

Falar em saúde, após tais vivências, passou a não ser mais falar apenas sobre a enfermagem e seus limites como especialidade, sobre as ações de Vigilância em Saúde; sobre a Estratégia Saúde da Família ou sobre a Gestão/Administração dos serviços públicos de 
saúde, mas também, a respeito das bases materiais de manutenção da vida e de um Sistema Único de Saúde, que necessita ser consolidado como política pública universal e resolutiva.

Assim, o objetivo geral desta tese foi, sob a perspectiva dos secretários municipais de saúde, conselheiros municipais de saúde (representante dos usuários) e usuários do SUS, analisar os determinantes sócio-históricos mais gerais ligados à saúde como mercadoria e os reflexos dessa racionalidade sob o Sistema Único de Saúde na Macrorregião Triângulo Sul do Estado de Minas Gerais. Os objetivos específicos voltaram-se para: A). Identificar como os processos de reificação e mercantilização da saúde interferem na gestão da Política Pública de Saúde dos municípios e da região. B). Examinar a prática da participação social no contexto da saúde subordinada de forma direta às relações de produção, ou seja, de que forma os sujeitos do estudo estão incorporados aos processos de gestão ou cogestão dos serviços de saúde e sua influência nos processos decisórios. C). Identificar os reflexos dos processos de reificação e mercantilização da saúde na Atenção à Saúde aos usuários do SUS.

A perspectiva teórica adotada neste trabalho permite amparar e desenvolver a tese de que a saúde, no Brasil, é um problema de Saúde Pública, não enquanto disfunção social, mas por ser expressão das contradições determinadas pelo desenvolvimento das relações de produção da sociedade, onde tudo é relacionado enquanto mercadoria.

O trabalho que ora apresentamos representa um pequeno passo em direção à ruptura com os laços que nos prendem à ideologia e a uma prática em saúde reificada, que pela sua impossibilidade de atingir a dinâmica social para transformá-la, não pode mais ser desempenhada sem ser negada ou superada a partir das contradições que ela própria encerra. 
CAPÍTULO 1 - REIFICAÇÃO E SAÚDE 

Este capítulo fundamenta o nosso trabalho, constituindo-se no referencial teórico para a crítica à prática da saúde fundamentada na determinação das relações reificadas. Desta forma, realizaremos breve discussão sobre o processo de reificação da saúde à luz, principalmente, de Karl Marx (1818-1883), Friedrich Engels (1820-1895) e Georg Lukács (1885-1971). Limitando o recorte, discutirei sobre a saúde enquanto categoria histórica em uma sociedade de consumo, midiatizada e globalizada. Com base na dialética do materialismo histórico frente às imposições das relações sociais de produção, tratarei da trajetória das Políticas Públicas de Saúde no Brasil, do início da ação estatal aos dias atuais, desvendando alguns momentos determinantes para a concepção, que se tem na atualidade, de saúde vista como mercadoria.

\subsection{O processo de reificação da saúde: coisificação global da vida}

"A desvalorização do mundo humano aumenta em proporção direta com a valorização do mundo das coisas"

Karl Marx, Manuscritos Econômico-Filosóficos

Para uma teoria do fenômeno da reificação da saúde, faz-se indispensável a definição e abordagem de alguns termos a ele fortemente associados como recursos de um mesmo fenômeno; ideologia, hegemonia, alienação, fetiche da mercadoria e naturalização.

Marx e Engels (2007) afirmam que a consciência humana é determinada pelas condições concretas de nossa existência, ou seja, ela é histórica e social. "Não é a consciência que determina a vida, mas sim a vida que determina a consciência" (p. 94). Desta forma, as representações que os indivíduos em sociedade criam para si mesmos "são uma expressão consciente - real ou ilusória - de suas verdadeiras relações e atividades, de sua produção, de seu intercâmbio, de sua organização social e política” (Marx \& Engels, 2007, p. 93).

Por conseguinte, o conceito de ideologia aparece em Marx, inicialmente, como equivalente de ilusão, falsidade, realidade enviesada, consciência equivocada que põem a realidade de cabeça para baixo (Löwy, 1991; Marx \& Engels, 2007). Não obstante, o conceito 
de ideologia ganhou significados diferentes na história do marxismo, podendo, então, ser redefinida como "ideias da classe dominante", que não seriam outra coisa que não a “expressão ideal das relações materiais dominantes, as mesmas relações materiais dominantes apreendidas como ideias; portanto, a expressão das relações que fazem de uma determinada classe a classe dominante, ou seja, as ideias de sua dominação" (Marx \& Engels, 2007, p. 47).

Bobbio, Matteucci e Pasquino (1998) destacam que em seu dinamismo psicológico:

A Ideologia como falsa motivação é análoga ao conceito psicanalítico de 'racionalização', com o qual se designa, precisamente, a elaboração de motivos fictícios para as próprias ações ou para os próprios comportamentos, cujos moventes reais permanecem inconscientes. Mas diferentemente do conceito de racionalização, o conceito de Ideologia tem natureza social, porque diz respeito aos comportamentos coletivos e não aos individuais; e, mais especificamente, os comportamentos coletivos que se instauram numa situação de poder. Segue-se que as crenças, às quais se pode atribuir o caráter da Ideologia, são também crenças coletivas, que encobrem ou mascaram os verdadeiros moventes da conduta, a nível do grupo ou do agregado social, e não a nível do indivíduo. Esta formulação da específica natureza social da Ideologia é claramente uma generalização do ponto de vista de Marx: ...que a Ideologia como falsa motivação se insere explicitamente nas relações de dominação do homem sobre o homem [itálicos nossos] (p. 595).

Somente se levarmos em conta o advento e a natureza do Estado moderno, "com a característica básica de unidade territorial dotada de um poder soberano" Dalari (1998a, p. 29), é que poderemos, nos termos clássicos, compreender a função implícita ou explícita da ideologia, ou seja, “a tentativa para fazer com que o 'ponto de vista particular da classe' que exerce a dominação (política, econômica, cultural, etc.) apareça para 'todos' os sujeitos sociais e políticos como 'universal' e não como interesse particular de uma classe determinada" (Chaui, 2000a, p. 19).

$\mathrm{Na}$ realidade, é a partir de uma análise profunda da formação social das ideologias, especialmente em A Ideologia Alemã, que Marx e Engels (1998) revolucionaram a teoria política. Pela primeira vez na história das ideias políticas, o Estado deixou de ser conceituado como entidade representativa dos interesses gerais e comuns da sociedade, sendo vinculado aos interesses de determinada classe social, isto é, aos interesses da classe dominante; no caso da sociedade capitalista, os interesses da burguesia (Marx \& Engels, 1998); fazendo do Estado moderno apenas um comitê para gerir os negócios comuns de toda a sociedade civil burguesa (Marx \& Engels, 2001). Para Althusser (1980),

a tradição marxista é peremptória: o Estado é explicitamente concebido... como aparelho repressivo. $\mathrm{O}$ Estado é uma «máquina» de repressão que, permite às classes dominantes (no século XIX à classe burguesa e à «classe» dos proprietários de terras) assegurar a sua dominação sobre a classe operária para a submeter ao processo de extorsão da mais-valia (quer dizer, à exploração capitalista) (p. 31). 
Gramsci, vivendo em um contexto histórico diferente, considera que para compreender a complexidade das sociedades de capitalismo avançado, torna-se necessário a ampliação da visão de Estado para além da esfera da superestrutura responsável pela coerção e manutenção da dominação da classe operária por meio da força. Para isso, distingue na totalidade da superestrutura duas dimensões, organicamente ligadas, a sociedade política e sociedade civil, que compõem a sua concepção de Estado ampliado (Coutinho, 2007). Tal fato é expresso em uma carta enviada a sua cunhada (Tatiana), em 7 de setembro de 1931. Nesta carta, Gramsci, ao abordar seu estudo sobre os intelectuais italianos escreve:

Este estudo leva também a certas determinaçons do conceito de Estado, que é entendido habitualmente como Sociedade política (ou até como aparato coercitivo para enquadrar a massa popular, segundo o tipo de produçom e a economia de um momento dado) e nom como um equilíbrio da Sociedade política com a Sociedade civil (ou hegemonia de um grupo social sobre a inteira sociedade nacional, exercida através das organizações chamadas privadas, como a igreja, os sindicatos, as escolas etc.) e precisamente na sociedade civil, nomeadamente, operam os intelectuais (Benedetto Croce, por exemplo, é umha espécie de papa laico e é um instrumento mui eficaz de hegemonia, mesmo se de quando em vez pode nom concordar com este ou aquele governo etc.) (Gramsci, 2011, p. 264).

Nesse contexto, um ponto convém ser mencionado, a saber, o da relação entre ideologia e o conceito gramsciano de hegemonia, no dinâmico entrelaçamento de duas esferas societárias, a sociedade civil e a sociedade política (Estado). Pela acepção conferida aos termos, por Gramsci (1980) e citados por M. Martins (2008):

'Sociedade civil', configura o conjunto de aparelhos e estruturas sociais, que buscam dar
direção intelectual e moral à sociedade, o que determina a hegemonia cultural e política de
uma das classes sobre o conjunto da sociedade; e a sociedade política, uma extensão da
sedimentação ideológica promovida pela sociedade civil, que se expressa por meio dos
aparelhos e atividades coercitivas do Estado, visando adequar as massas à ideologia e à
economia dominante [itálicos nossos] (p. 83).

A concepção de sociedade civil foi a base para Gramsci demonstrar que a classe dominante mantém o poder não apenas mediante a coerção, mas, também, por meio do consenso, ou seja, pela hegemonia. Tendo os intelectuais assumido neste processo papel fundamental em difundir e conservar a concepção do mundo que atende aos interesses da classe dirigente ou grupo dominante.

Os intelectuais são os 'prepostos' do grupo dominante para o exercício das funções subalternas da hegemonia social e do governo político, isto é:

1) do consenso 'espontâneo' dado pelas grandes massas da população à orientação impressa pelo grupo fundamental dominante à vida social, consenso que nasce 
'historicamente' do prestígio (e, portanto, da confiança) obtido pelo grupo dominante por causa de sua posição e de sua função no mundo da produção;

2) do aparelho de coerção estatal que assegura 'legalmente' a disciplina dos grupos que não 'consentem', nem ativa nem passivamente, mas que é constituído para toda a sociedade na previsão dos momentos de crise no comando e na direção, nos quais desaparece o consenso espontâneo [itálicos nossos] (Gramsci, 2001, pp. 2021).

Embora Gramsci (2001, p. 20), utilize como conceito de sociedade civil "o conjunto de organismos designados vulgarmente como "privados", com distinção conceitual do termo em relação ao utilizado por Marx e Engels (1998, p. 33), qual seja, “o conjunto das relações materiais dos indivíduos dentro de um estágio determinado de desenvolvimento das forças produtivas", o filósofo italiano não "perde de vista o papel determinante da estrutura, ainda que no interior de uma concepção dialética da relação entre estrutura e superestrutura" (Liguori, 2003, p. 178, citado por A.A. Ferreira, 2006, p. 34). Nesse sentido, tal distinção não significa uma ruptura; pelo contrário, suas análises assinalam os elementos materiais responsáveis pela difusão da ideologia dominante. "A hegemonia gramscista é a primazia da sociedade civil sobre a sociedade política" (Portelli, 1977, p. 65, citado por Alves, 2010, p. 74). Para Gramsci, conquistar a hegemonia significa conseguir que a ideologia de determinado grupo social, por meio do consenso ou coerção, torne-se a direção intelectual e moral para a sociedade em determinado momento histórico.

Em $O$ Capital, a teoria marxista conduz à desmistificação do fetiche da mercadoria, indispensável ao entendimento do conceito de ideologia, de onde se desvenda:

O caráter alienado de um mundo em que as coisas se movem como pessoas e as pessoas são dominadas pelas coisas que elas próprias criam. Durante o processo de produção, a mercadoria ainda é matéria que o produtor domina e transforma em objeto útil. Uma vez posta à venda no processo de circulação, a situação se inverte: o objeto domina o produtor. $\mathrm{O}$ criador perde $\mathrm{O}$ controle sobre sua criação e o destino dele passa a depender do movimento das coisas, que assumem poderes enigmáticos. Enquanto as coisas são animizadas e personificadas, o produtor se coisifica. Os homens vivem, então, num mundo de mercadorias, um mundo de fetiches. Mas o fetichismo da mercadoria se prolonga e amplifica no fetichismo do capital.

O capital se encarna em coisas: instrumentos de produção criados pelo homem. Contudo, no processo de produção capitalista, não é o trabalhador que usa os instrumentos de produção. Ao contrário: os instrumentos de produção - convertidos em capital pela relação social da propriedade privada - é que usam o trabalhador. Dentro da fábrica, o trabalhador se torna um apêndice da máquina e se subordina aos movimentos dela, em obediência a uma finalidade - a do lucro - que lhe é alheia. O trabalho morto, acumulado no instrumento de produção, suga como um vampiro (a metáfora é de Marx) cada gota de sangue do trabalho vivo fornecido pela força de trabalho, também ela convertida em mercadoria, tão venal quanto qualquer outra [itálicos nossos] (Marx, 1996, p. 34). 
Marx designava por fetiche uma "ideologia espontânea" que essencialmente teria por meta ocultar o fato de que o lucro tem sua origem exclusivamente na mais-valia. Assim, o fetichismo constituiria um engodo, ilusão ou consciência equivocada e participaria da autojustificação da sociedade capitalista (Bottomore, 2001; Jappe, 2014).

O fetiche recupera o processo de alienação ${ }^{4}$ com base no desenvolvimento históricoeconômico específico da sociedade capitalista. Para Marx (1996):

A alienação era vista enquanto processo da vida econômica. O processo por meio do qual a essência humana dos operários se objetivava nos produtos do seu trabalho e se contrapunha a eles por serem produtos alienados e convertidos em capital (p. 9).

Mészáros (1978, p. 132, citado por Netto, 1981, p. 73), assevera que "sem uma teoria da alienação é impossível pensar a problemática do fetichismo". Netto destaca que, para Marx:

O 'fetichismo é uma modalidade de alienação'. Todavia, quando a concretização histórica alcançada pela sua reflexão a partir de 1857-1858 permite-lhe colocar integralmente o problema do fetichismo, a teoria da alienação torna-se um complexo teórico-critico que passa a abarcar um amplo conjunto categorial onde desempenhará papel-chave a noção de 'reificação $o^{5}$ ' [itálicos nossos] (p.73).

De acordo com Resende (1992, p. 156, citado por Crocco, 2009, p. 50), o que há de específico neste processo é "o predomínio da coisa, do objeto sobre o sujeito, o homem; é a inversão entre a verdade do processo pelo que ele aparenta ser em sua forma imediata. E nisto se aproximam os conceitos de alienação, fetichismo e reificação".

Em História e Consciência de Classe, Lukács (1974) extrai do conceito de fetichismo da mercadoria, a teoria do fenômeno da reificação. Para o autor, a análise da mercadoria, ou melhor, "do caráter fetichista da mercadoria como forma de objetividade" (p. 98) e o comportamento do sujeito que lhe está reificado são "os problemas centrais, estruturais da sociedade capitalista em todas as suas manifestações vitais" (p. 97). O autor ainda acrescenta que somente com a solução do enigma da 'estrutura' da mercadoria seria "possível descobrir,

\footnotetext{
4 "Processo pelo qual alguém ou alguma coisa é obrigado a se tornar outra coisa diferente daquilo que existe propriamente no seu ser" (Chiodi, 1965, citado por Bottomore, 2001, p. 20).

5 "É o ato (ou resultado do ato) de transformação das propriedades, relações e ações humanas em propriedades, relações e ações de coisas produzidas pelo homem, que se tornaram independentes (e que são imaginadas como originalmente independentes) do homem e governam sua vida. Significa igualmente a transformação dos seres humanos em seres semelhantes a coisas, que não se comportam de forma humana, mas de acordo com as leis do mundo das coisas" (Bottomore, 2001, p. 314).
} 
na estrutura da relação mercantil, o protótipo de todas as formas de objectividade e de todas as formas correspondentes de subjectividade na sociedade burguesa" (p. 97). Para Lukács (1974), a essência da estrutura mercantil se estabelece na reificação, ou seja:

No facto de uma ligação, uma relação entre pessoas, tomar o caráter de uma coisa, e ser, por isso, de uma 'objetividade ilusória' que, pelo seu sistema de leis próprio, aparentemente rigoroso, inteiramente fechado e racional, dissimula todo e qualquer traço da sua essência fundamental: a relação entre homens (p. 97). Deste fenômeno estrutural fundamental há que reter, antes do mais, o que faz com que o homem se oponha à sua própria actividade, ao seu próprio trabalho, com algo de objectivo, independente dele e que o domina pelas suas leis próprias, estranhas ao homem. Isto verifica-se tanto no plano objectivo como no plano subjectivo. 'Objectivamente', surge um mundo de coisas acabadas e de relações entre coisas (o mundo das mercadorias e do seu movimento no mercado) [itálicos nossos] (pp.100-101).

De acordo com Lukács (1974), se seguirmos o caminho da divisão social do trabalho, dominada pela mecanização progressiva, das formas mais elementares de produção até a indústria moderna, observaremos uma crescente eliminação das propriedades qualitativas humanas e individuais do trabalhador. O retalhamento do processo de trabalho em operações parciais abstratamente racionais, em proporção sempre crescente, destrói a relação entre o trabalhador e o produto como totalidade, reduzindo seu trabalho a uma função específica, mecânica e repetitiva.

“A mecanização, expressa na fragmentação do trabalho e na racionalização de seus processos em operações parciais, não é somente uma realidade material, mas também espiritual, pois introduz na subjetividade do trabalhador os mesmos processos reificados da produção industrial" (Crocco, 2009, p. 52).

Com a moderna decomposição 'psicológica' do processo de trabalho (sistema de Taylor), esta mecanização racional penetra até à 'alma' do trabalhador: até as suas propriedades psicológicas são separadas do conjunto da sua personalidade e objectivadas em relação a esta para poderem ser integradas em sistemas racionais especiais e reduzidas ao conceito calculador (Lukács, 1974, p. 102).

Há que se denunciar a efetiva redução do trabalhador a um espectador indefeso frente à naturalização dos fenômenos econômicos e seu status de dependência total destes. Para M.A. Figueiredo (1989):

A fragmentação do trabalho fragmenta o trabalhador: criando o fetiche de que na produção as características e particularidades humanas são as 'fontes de erro', suscetíveis de mensuração e controle, negando ao homem sua real posição no trabalho, que é a sua condição de agente no processo. Coloca o trabalhador de tal maneira diante de um sistema que funciona independente dele, que o submete às suas leis 'naturais' e inquestionáveis e transforma a sua atividade numa rotina que acaba integrando até sua personalidade (p. 25). 
Ou seja, ocorre uma naturalização das relações que são eminentemente sociais, como relações entre "coisas". Crocco (2009) e Lukács (1974) destacam que frente a este processo produtivo estranhado, a universalidade da categoria mercantil e o processo de mecanização/fragmentação do trabalho promovem a percepção de uma realidade insuperável, baseada na troca abstrata. A atividade do trabalhador perde o seu caráter de ativo para se tornar uma atitude "contemplativa", que se manifesta como um sistema acabado e fechado, reduzindo o espaço e o tempo a um mesmo denominador. A questão já não é qualidade; a quantidade decide.

Com a universalidade da categoria mercantil, esta relação altera-se radical e qualitativamente. $O$ destino do operário passa a ser o destino geral de toda a sociedade, uma vez que a generalização desse destino é a condição necessária para que o processo de trabalho nas empresas se modele segundo esta norma.... É, pois absolutamente necessário que o conjunto da satisfação das necessidades da sociedade se desenrole sob a forma de tráfico mercantil. Quer isto dizer, contudo, que o princípio da mecanização e da possibilidade racional de tudo calcular deve abarcar o conjunto das formas de manifestação da vida. Os objetctos que correspondem à satisfação das necessidades não aparecem já como produtos do processo orgânico da vida de uma comunidade, mas como objetos isolados cuja posse ou não posse depende de cálculos racionais [itálicos nossos] (Lukács, 1974, pp. 105-106).

Em síntese, "o destino do trabalhador que se torna universal para toda a sociedade é o processo que transforma tudo em valor-de-troca. A reificação está presente no trabalho e na consciência do indivíduo e na totalidade da sociedade dominada pela mercadoria” Crocco (2009, p. 53). De acordo com Lukács (1974), o capitalismo moderno atua no sentido de "substituir por relações racionalmente reificadas as relações originais em que eram mais transparentes as relações humanas" [itálicos nossos] (p. 106).

A atividade em saúde não foge às consequências da reificação/naturalização. A decomposição do trabalho em saúde leva à decomposição do processo de cuidado: profissionais e usuários perdem sua integridade psicológica, submetidos a um destino inelutável, uma vez que seu destino é o devir de toda a sociedade. A atividade em saúde substituiu o foco das relações entre homens pela abordagem das relações reificadas do capitalismo avançado. A atividade humana integrada foi substituída pela medicina baseada em evidências, analisada experimentalmente e associada às mercadorias enquanto resposta a sintomas de um corpo biológico retalhado, em um mundo mecânico, com leis próprias, naturais e independentes do sujeito. O estudo dos fenômenos humanos integrados foi substituído pelo estudo das respostas imediatas às causas biológicas das doenças, ao ambiente e ao mercado. 
A atuação em Saúde, de um modo geral, carrega consigo contradições determinadas pelo desenvolvimento das forças produtivas da sociedade, que baniu e vem gradativamente eliminando o componente humano do trabalho, desvitalizando a relação profissionalpaciente/família. O avanço tecnológico não deixa alternativas para o profissional de saúde; a objetivação do tratamento é o reflexo da dicotomia entre o conhecimento técnico e a competência social, comum na formação e que coloca o profissional frente às questões características de sua especialidade. A formação profissional, direcionada por esta lógica objetiva, prioriza a competência técnica em detrimento da sensibilidade social e neste universo reificado a racionalidade clínica prevalece (M.A. Figueiredo, 2003, p. 1).

Na atividade em saúde, a concepção de especialidades como qualidade total do fazer, naturalmente expressando significados conforme a posição social do seu proponente no processo produtivo, estreita-se, enquanto movimento, ao fetiche da mercadoria, ganhando um sentido comprometido e articulado a interesses do sistema social produtor de mercadorias, processo esse reificado pelos valores da sociedade capitalista (Puccini \& Cecílio, 2004).

Segundo Lefèvre (1991) e Vianna (2002), a saúde historicamente adaptou-se à lógica do mercado e aparece hegemonicamente, na prática reificada, como mercadoria, podendo ser vendida e comprada, naturalmente a um custo elevado. Ela toma forma de bens de consumo que aparecem como propiciadores de saúde; a propaganda que o diga:

Golden Cross é Saúde. (Para quem?);

Hepatovis é a saúde de seu fígado. (Cadê o resto?);

Apracur pra curar; pra curar, Apracur. (Apracur está doente?);

Tomou Doril, a dor sumiu. (E a origem, onde está?).

Nesse sentido, a saúde (reificada) passa de condição preliminar natural do ser humano bem formado para uma mercadoria passível de ser adquirida no mercado de bens de consumo (Lefêvre, 1991).

\subsection{O mercado: pretensão de caminho exclusivo e universal}

De acordo com Marx (1996),

a circulação de mercadorias é o ponto de partida do capital. Produção de mercadorias e circulação desenvolvida de mercadorias, comércio, são os pressupostos históricos sob os quais ele surge. Comércio mundial e mercado mundial inauguram no século XVI a moderna história da vida do capital [itálicos nosso] (p. 267). 
Para Ianni (2001), "na base da internacionalização do capital estão a formação, o desenvolvimento e a diversificação do que se pode denominar "fabril a global"” (p. 57). Segundo o autor, "o mundo transformou-se na prática em uma imensa e complexa fábrica, que se desenvolve conjugadamente com o que se pode denominar "shopping center global'" (p. 57). A nova divisão internacional do trabalho e da produção, envolvendo o fordismo, o neofordismo, o toyotismo, a flexibilização e a terceirização, amplamente potencializados pela disseminação e generalização dos meios de comunicação e rede mundial de computadores, concretiza a globalização do capitalismo, em termos geográficos e históricos.

Mészáros (2011) assevera que "a 'globalização"6, muito idealizada em nossos dias, na realidade, significa o desenvolvimento necessário de um sistema internacional de dominação e subordinação" [itálicos nosso] (p. 111) e destaca a instituição de um sistema "duplo padrão':

Em casa (ou seja, nos países "metropolitanos" ou "centrais" do sistema do capital global), um padrão de vida bem mais elevado para a classe trabalhadora - associado à democracia liberal e, na "periferia subdesenvolvida", um governo maximizador da exploração, implacavelmente autoritário (e, sempre que preciso, abertamente ditatorial), exercido diretamente ou por procuração (Mészáros, 2011, p. 111).

De acordo com Ianni (2001), “em um nível mais do que evidente, o principal tecido da aldeia global tem sido o mercado, a mercantilização universal, no sentido de que tudo tende a ser mercantilizado, produzido e consumido como mercadoria" [itálicos nossos] (p. 126).

É assim que a metáfora da 'mão invisível', idealizada pelo liberalismo clássico nos horizontes do Estado-nação, ressurge idealizada pelo neoliberalismo nos horizontes da globalização. Aos poucos, as produções e reproduções da cultura de massa em escala mundial criam a ilusão de uma universalização das condições e possibilidades do mercado e da democracia, do capital e da cidadania (Ianni, 2001, p. 133).

Para Mayer (2006), o neoliberalismo, enquanto generalização das forças do mercado na 'ordem do capital', foi e é uma reação teórica e política veemente contra o Estado intervencionista e de bem-estar social. Segundo Iamamoto (1999), o Estado seria responsabilizado por todas as mazelas que afetam a sociedade; sua intervenção é denunciada como destruidora da liberdade dos cidadãos e da vitalidade da concorrência e, em contrapartida, aparece o 'mercado santificado' como baluarte da eficiência e da competência para gerir os caminhos da humanidade.

\footnotetext{
6 “Tendência que emana da natureza do capital desde o seu início” (Mészáros, 2011, p. 111)
} 
Hinkelammert (1989) destaca que "esta pertença da humanidade ao capital, esta servidão em relação ao capital, é o centro de toda a ideologia burguesa” (p. 196).

Esta ênfase nos direitos concretos à vida desemboca, portanto, numa crítica da ideologia burguesa. Esta celebra exatamente o capital ou o mercado como o grande doador da vida. Ela parte desta pertença da humanidade ao capital, sem fundamentá-la, e constata, por conseguinte, que finalmente já ninguém pode viver sem o capital. Como o capital domina todas as fontes da vida, ninguém pode chegar à vida a não ser através do capital. Quanto mais total for o mercado e o capital, tanto mais parece o capital ser o doador da vida. A doutrina neoliberal do mercado total nos apresenta isso como seu resultado. O capital dá trabalho, o capital dá renda, o capital dá desenvolvimento, e sem o capital não há trabalho, nem renda nem desenvolvimento. O capital parece ser a fonte verdadeira de toda a humanidade, sendo também a liberdade. Onde o capital não dá trabalho ou renda ou desenvolvimento, ali há escassez de capital. Por isso se deve fomentar a acumulação de capital, para que haja vida. Quanto mais capital, mais vida. Não pode haver vida sem esta pertença ao capital. A tarefa básica do homem é, portanto, conservar a confiança do capital. Onde o capital perde esta confiança, ocorre a fuga e, com ele, fogem todas as fontes da vida. Por isso há de se organizar a economia em função do mercado total para que o capital volte a encontrar sua confiança e regresse. Com ele regressam as fontes da vida. Do ponto de vista desta ideologia burguesa, faz falta, precisamente, manter e aprofundar a situação de exploração para que haja-garantia de vida [itálicos nossos].

Por fim, não poderíamos concluir este breve tópico sem uma alusão, bem sucinta, à

“' mercadificação' global da vida”, ou seja,

à aplicação crescente de critérios de mercado a aspectos da vida humana em sociedade, que não têm nenhuma relação direta com a produção e distribuição de bens materiais. Em termos genéricos, é o que se vem chamando de 'expansão do domínio da economia' ou, numa linguagem mais crítica, porém ambígua, de 'imperialismo da economia'. Em termos mais específicos, trata-se de uma concepção mercadológica, por exemplo, da criação de consensos, da tomada de decisões coletivas, da educação, da saúde e da própria religião (Assmann, 1989, p. 248). 


\title{
1.3. A saúde como mercadoria: de elemento da vida humana a produto que deve ser consumido no mercado
}

\author{
"A fome é a fome, mas a fome que se satisfaz com \\ carne cozinhada, comida com faca e garfo, não é \\ a mesma fome que come a carne crua, servindo- \\ se das mãos, das unhas, dos dentes. Por \\ conseguinte, a produção determina não só o \\ objeto do consumo, mas também o modo de \\ consumo, e não só de forma objetiva, mas \\ também subjetiva. Logo, a produção cria o \\ consumidor" \\ Karl Marx, Introdução à crítica da economia \\ política
}

Apesar do trocadilho, podemos dizer que a saúde, no Brasil, é um problema de Saúde Pública, não enquanto disfunção social, mas por ser expressão das contradições determinadas pelo desenvolvimento das relações de produção da sociedade, onde tudo vira mercadoria.

Lefèvre (1995, p. 139) coloca que:

A saúde faz parte daquele conjunto de sentidos que são eminentemente vagos, imprecisos e, ao mesmo tempo, muito carregados de valorações positivas, passíveis de intenso investimento libidinal. Por isso, saúde é um tipo especial de nome, na medida em que o ato social de nomeação que ela expressa acaba tendo o sentido adicional de "dar corpo", concretude e materialidade à utopia, nomeando o inominável ou, no registro psicológico, dando forma ao objeto de desejo.

Ora, neste particular Lefèvre $(1991,1995,1997)$ desvenda o processo de reificação da saúde, na medida em que a palavra/coisa 'saúde' passa a ser associada a coisas mais materiais, ou seja, objetos investidos de saúde como: alimentos saudáveis, suplementos alimentares, vitaminas, medicamentos, cintos de segurança, airbags, ambulâncias, exames, equipamentos de ultrassom, ressonância magnética, mamógrafos, etc. Para o autor, tais “"coisas', por sua vez, produzem e reproduzem - evidentemente se compradas, já que são mercadorias - 'saúde mesmo', isto é, estados concretamente atestáveis de bem estar" análogos como: transporte adequado e seguro de um paciente grave para um centro de maior concentração tecnológica; 
alívio da dor de cabeça; potência sexual; energia para realização de performances escolares ou esportivas e muitos outros. Ou seja, “'Saúde’ mais-que-real, que se manifesta nos corpos e mentes concretas dos indivíduos, motoristas, esportistas, professores, alunos, pacientes, vestibulandos, todos, em última e decisiva instância, consumidores de 'Saúde"” [itálicos nossos] (Lefèvre, 1995, p. 139).

A saúde é expropriada da sua condição de premissa existencial do ser humano para ser 'apenas' recuperada e recuperável num mercado de bens de consumo, onde se transforma em uma necessidade jamais satisfeita. Pois, assim como a fome, deve ser sempre (re)satisfeita cotidianamente com mais e novas mercadorias, deixando eclipsada a dimensão das relações humanas (Lefêvre, 1991).

A saúde e a doença são, dicotomicamente, reduzidas aos seus aspectos puramente biológicos. Nega-se, assim, a subjetividade do "paciente" e se desconsideram as questões sócio-históricas do processo saúde/doença. Desta forma, através deste reducionismo biológico,

a sociedade de consumo, ao mesmo tempo em que promove, por todos os seus canais de comunicação, a ideia de que qualquer sofrimento, qualquer dor, qualquer estado, enfim, que fuja daquilo que ela institui como padrão, inclusive estético, constitui algo insuportável para o indivíduo; por outro lado, oferece a solução mágica, na ponta dos dedos: os comprimidos (Pierce, 1975, citado por Lefèvre, 1983, p. 502).

Com efeito, nas formações sociais capitalistas modernas, qualquer produto, mercadoria ou serviço aparece, socialmente, investido do sentido ou significado que lhe confere o senso comum, ou seja, de coisa "benéfica" (o que incluí todas as inúmeras mercadorias "propiciadoras de saúde"), que aparece como "solução" imediata de uma situação ou estado maléfico prévio ou como recurso preventivo ao risco do surgimento de estados ou situações como a doença, a morte, o baixo desempenho escolar, sexual, o envelhecimento, etc. (Lefêvre, 1983, 1991).

U. Beck (1992, citado por Bauman, 1997, p. 228) destaca que no curso da modernização passamos da "sociedade industrial" à fase da "sociedade de risco", na qual "a lógica da produção de riqueza gradativamente se substitui pela lógica da evitação de risco sendo agora a principal questão: como se podem prever, minimizar, dramatizar ou desafiar os riscos e os perigos sistematicamente produzidos como parte da modernização?” [Itálicos nossos].

Para Giddens (2002), “a modernidade é uma cultura do risco (...) [de modo que] o conceito de risco se torna fundamental para a maneira como tanto os leigos quanto os 
especialistas organizam o mundo social" [itálicos nossos] (p. 11). Para o autor, o mundo o qual ele chama de "alta modernidade" é apocalíptico, porque introduz riscos que gerações anteriores não tiveram que enfrentar e assevera: "viver no universo da alta modernidade é viver num ambiente de oportunidade e risco, concomitantes inevitáveis de um sistema orientado para a dominação da natureza e para a feitura reflexiva da história" (p. 104). Giddens alerta: há uma implicação tácita, mas difundida na descrição da "sociedade de risco", de que "o universo dos eventos futuros está aberto para ser moldado pela intervenção do homem - dentro de limites que, tanto quanto possível, são regulados pela aferição do risco" [itálicos nossos] (p. 104).

O monitoramento regular e detalhado dos riscos para a saúde, oferece um excelente exemplo, não apenas da reflexividade rotineira em relação ao risco extrínseco, mas da interação entre sistemas especializados e o comportamento leigo em relação ao risco. Especialistas médicos e outros pesquisadores produzem os materiais a partir dos quais são estudados os perfis de risco. Mas esses perfis não são mais um segredo dos peritos. A população em geral está consciente deles, ainda que muitas vezes de maneira vaga, e de fato a medicina e outras agências se dão ao trabalho de pôr suas descobertas ao alcance dos leigos. Os estilos de vida seguidos pela população como um todo são influenciados pela recepção dessas descobertas, embora normalmente existam diferenças de classe na alteração dos padrões de comportamento, com os grupos profissionais e mais educados na liderança. Mas o consenso da opinião informada - se existir tal consenso - pode mudar mesmo enquanto as mudanças de estilo de vida que provocaram anteriormente estiverem sendo adotadas. Não nos esqueçamos de que o hábito de fumar foi alguma vez defendido por setores da profissão médica como relaxante; e se dizia que a carne vermelha, a manteiga e o creme eram importantes para construir corpos saudáveis [itálicos nossos] (Giddens, 2002, p. 114).

Bauman (1997), por sua vez, desvenda o que o pretenso curto-circuito entre "reflexividade" e "detalhamento de risco" deixa de ver, a "verdade no assunto", ou seja,

os interesses poderosos que, na sociedade de consumo orientada pelo mercado, devem surgir em torno de toda ansiedade, pânico ou medo, capazes de se desenvolverem como 'pontos-devenda' no esforço contínuo de comerciar artigos pensados para o consumo individual. $O$ valor comercial potencial do medo do risco é infinito. Pode-se embarcar em jogo de qualquer tamanho (ou seja, em qualquer volume de venda) em função de pavores, engenhosamente fomentados, perante riscos de saúde... Combater riscos é agora grande negócio altamente lucrativo - e continuamos a ouvir com frequência que também é, como se espera, autoperpetuador: curas oferecidas a perigos que vemos (ou nos são mostrados, ou somos incitados a imaginar) criam normalmente perigos que não vemos (ou não nos mostraram, ou nos impediram de imaginar)... Para manter bem lubrificadas as rodas do mercado consumidor, é preciso constante suprimento de novos perigos bem propalados. E os perigos, de que se precisa, devem ter capacidade de se traduzir em demanda do consumidor: esses perigos são 'feitos na medida' para o combate privatizado de riscos. Pode-se concluir que a maneira como se institucionalizou a administração do risco na sociedade de consumo permite o desdobramento da reflexividade não tanto como instrumento de liberdade individual, de controle do destino, ou de 'colonização do futuro', mas como dispositivo para refundir a ansiedade pública em lucros de corporações, ajudando a desviar os interesses públicos do próprio mecanismo perpetuador do perigo [itálicos nosso] (p. 233). 
Na percepção, de Bauman (1997), Giddens (2002) e Giddens e Pierson (2000), os "perigos coletivamente produzidos" ou "riscos fabricados" ou, ainda, "incertezas fabricadas" são "descarregados" nos mundos privatizados das vítimas individuais e traduzidos como realidades que devem ser enfrentadas individualmente (Compre! Compre! Compre.). Há, ao ver de Bauman (1997), uma pré-seleção e um pré-processamento dos riscos, "de sorte que a consciência de perigos vem junto com a intimação da censura ao indivíduo por continuar a exposição ao risco e da responsabilidade individual de evitar o risco" [itálicos nossos] (p. 231). O autor destaca que as estatísticas médicas são um bom exemplo deste ponto de vista, pois implicam, sem necessidade de ulterior argumento e sem oferecer objeção sensata, que virtualmente tudo o que se pode fazer para minimizar os riscos à saúde repousa nas próprias mãos da pessoa consciente da saúde.

Para Bakhtin (2006, p. 36),

a consciência adquire forma e existência nos signos criados por um grupo organizado no curso de suas relações sociais. Os signos são o alimento da consciência individual, a matéria de seu desenvolvimento, e ela reflete sua lógica e suas leis. A lógica da consciência é a lógica da comunicação ideológica, da interação semiótica de um grupo social. A realidade dos fenômenos ideológicos é a realidade objetiva dos signos sociais. As leis dessa realidade são as leis da comunicação semiótica e são diretamente determinadas pelo conjunto de leis sociais e econômicas.

A esse respeito Lefêvre (1997, p. 5), esclarece:

Para a linguística e para a semiótica, o significante é o aspecto ou dimensão material do signo; já o significado representa a parte ideal ou emocional deste signo. Assim, a saúde pode ser vista como um signo cujo significante é o nome 'saúde' e cujo significado é o desejo de 'saúde'. Saúde e seus correlatos, enquanto significantes, nomeiam, concentram, canalizam e, em termos foucaltianos, 'disciplinam', o desejo, por natureza, disperso, volátil, descontraído, indisciplinado, incivilizado, bruto. Assim fazendo, ensejam e viabilizam sua venda.

Com efeito, sob a insígnia da saúde (reificada) torna-se possível vender "o que se quer", seja pela "expansão da carência de saúde"; seja para "solução imediata de um estado maléfico"; ou para "evitação de risco"; correção de "desvio de padrão"; por estética; pela boa forma; para emagrecer; para engordar; pelo bom desempenho sexual, físico e/ou mental; pelo bom funcionamento do seu intestino; pelo medo ou por uma longa vida (de consumo), etc.

Outra verdade no assunto é o papel da publicidade na sociedade capitalista. A manipulação planejada da informação e da comunicação promove comportamentos de consumo, ou seja, a propaganda é a alma do consumo. A esse respeito, A. Nascimento (2007) 
destaca, por exemplo, que a propaganda possui papel fundamental no aumento do consumo de medicamentos, ou melhor, de qualquer mercadoria.

É o que afirma Giddens (2002, p. 182): “o estabelecimento de padrões regulares de consumo, promovidos pela propaganda e outros métodos, torna-se central para o crescimento econômico. Em todos esses sentidos, a mercantilização influencia o projeto do eu e o estabelecimento de estilos de vida".

Como esclarece Bauman (2008a), na alta modernidade, a criação de necessidades está tomando o lugar da regulamentação normativa, a "propaganda substitui a doutrinação ideológica e a sedução ocupa o lugar do policiamento e da coerção" (p. 92). A maior parte da população está, assim, integrada à sociedade contemporânea em seu papel de consumidora; tal integração, entretanto, só se mantém enquanto as carências excederem os níveis de satisfações atuais. Ou seja, na sociedade de consumo, "a promessa de satisfação só permanece sedutora enquanto o desejo continua 'insatisfeito'; mais importante ainda, quando o cliente não está 'plenamente satisfeito'”' [itálicos do autor] (Bauman, 2008b, p. 63).

Em consequência, os indivíduos não necessitam ser reprimidos em seus impulsos naturais, muito menos na tendência a subordinar seu comportamento ao princípio do prazer; eles não precisam ser vigiados, nem policiados. Tal função foi assumida pelo mercado ${ }^{7}$. "Os indivíduos se submetem voluntariamente ao prestígio da propaganda e, assim, não necessitam de qualquer crença 'legitimadora'. Sua conduta se torna manejável, previsível, e, portanto, não ameaçadora, pela multiplicação de necessidades, e não pelo enrijecimento das normas" (Bauman, 2010, p. 227).

A experiência transmitida pela mídia é parte importante de tudo isso. Os meios de comunicação de massa rotineiramente apresentam modos de vida aos quais - deixam implícito - todos deveríamos aspirar; os estilos de vida dos mais prósperos são, de uma forma ou de outra, exibidos à vista de todos e retratados como dignos de imitação. Mais importante, porém, e mais sutil, é o impacto das narrativas que a mídia traz. Aqui não há necessariamente sugestão de um estilo de vida a ser desejado; em vez disso, desenvolvem-se estórias de modo a criar uma coerência narrativa com a qual o leitor ou espectador possa identificar-se (Giddens, 2002, p. 184).

Para Weber (1995, p. 153), pensar a comunicação de modo estratégico é “ingressar no universo fascinante de uma cultura estética, marcada por imagens, estruturas, tecnologia e especialistas preparados para gerar produtos e informações passíveis de assimilação por todos os segmentos da sociedade que, a cada dia, melhor os compreende e assimila”. Processo este

\footnotetext{
${ }^{7}$ Pela transformação da tecnologia da informação em objeto de consumo privado, a sociedade 'vigilante' foi substituída, como sugere Attali (1981 citado por Bauman, 2010, p. 227), por uma sociedade 'autovigilante'.
} 
inevitável e irreversível, que tem por objetivo informar e solicitar uma atitude das pessoas. "A exposição das pessoas aos meios de comunicação, de alguma forma, lhes municia de uma crítica sobre o 'feio' e o 'bonito' das comunicações veiculadas. E isto não tem nenhuma relação com o analfabetismo ou singularidades regionais".

A esse respeito, Baudrillard $(1991,2011)$ concentra-se mais diretamente sobre o tema do consumo e sua ligação com os meios de comunicação de massa, destacando o predomínio da linguagem da propaganda, da sedução, do poder de convencimento da publicidade, como o mais notável meio de comunicação de massas da nossa época. Para o autor, a generalização dos fait divers ${ }^{8}$ edificados pelos mass media ${ }^{9}$ caracteriza o reino do "pseudo-acontecimento" e a "sociedade de consumo", que retalham o real fabricando um sistema de leitura do mundo transformado em sistema de signos.

O acontecimento bruto surge como permuta, não como material de troca. Só se torna 'consumível' depois de filtrado, retalhado e reelaborado ${ }^{10}$ por toda uma cadeia industrial de produção - os mass media. Opera-se em toda extensão da vida cotidiana um imenso processo de simulação, à imagem dos 'modelos de simulação' a que se aplicam as ciências operacionais e cibernéticas. 'Fabrica-se' um modelo pela combinação dos rasgos ou elementos do real; fazse lhe causar determinado acontecimento, estrutura ou situação futura e tiram-se conclusões táticas, a partir das quais se atua sobre a realidade. A verdadeira realidade é abolida e volatilizada em proveito da neo-realidade do modelo materializado pelo próprio meio de comunicação [itálicos do autor] (Baudrillard, 2011, p. 164).

Desta maneira, consegue-se "um universo onde existe cada vez mais informação e cada vez menos sentido" (Baudrillard, 1991, p. 103). Processo este associado, de acordo com Lefèvre (1995, p. 145), aos “"holdings midiáticos"ll de alcance planetário, capazes de colocar no mercado, com eficiência e eficácia crescentes, mensagens e discursos altamente funcionais na sua missão de racionalizar motivações e interesses individuais e coletivos, fazendo-os desaguar em comportamentos de consumo" [itálicos do autor].

8 Termo francês que significa fatos diversos, que representa escândalos, crimes, curiosidades, fatos estereotipados, drama passional, política, guerra, economia, ciência, entretenimento e bizarrices (Barthes, 1991). Ou seja, pode ser caracterizado como sinônimo de imprensa sensacionalista.

${ }^{9}$ Designação genérica, em inglês, dos meios, veículos e canais de comunicação, como, por exemplo, internet, jornal, revista, rádio, televisão, outdoor, etc. Pode ser utilizado apenas media, redução do termo em inglês mass media. Em português: mídias.

10 De acordo com Baudrillard (1991), trata-se da mesma operação que executa a maquiagem do rosto: substituição sistemática dos traços reais, mas discordantes, por um feixe de mensagens abstratas e coerentes, a partir de elementos técnicos e de um código de significação impostos (o código de "beleza").

11 As holdings são sociedades não operacionais que tem seu patrimônio composto de ações de outras companhias. São constituídas ou para o exercício do poder de controle ou para a participação relevante em outras companhias, visando nesse caso, constituir a coligação. Quando exerce o controle, a holding tem uma relação de dominação com as suas controladas, que serão suas subsidiárias ou afiliadas (Carvalhosa, 2009, 14). 
Para V.C. Oliveira (1995), do ponto de vista da linguagem, os meios de comunicação buscam tornar claras as mensagens, tanto com o objetivo de evitar ambiguidades interpretativas, quanto em aumentar o coeficiente de comunicabilidade com os públicos. Contudo, essa dimensão estética e pedagógica não significa necessariamente uma preocupação em democratizar as informações, e sim garantir determinadas interpretações, eliminando ambiguidades e subjetividades humanas presentes no processo comunicacional.

Ao organizar acriticamente sua produção discursiva submetendo-a a lógica da economia de mercado, que reflete os interesses particulares e políticos do sistema produtivo, os meios de comunicação - com destaque para televisão e internet - acabam promovendo um modelo de saúde e de assistência médica reducionista com viés marcadamente biológico, sem contudo colocar em pauta qualquer discussão sobre os desafios sócio-históricos que se interpõem à construção de uma política pública de saúde universal, resolutiva, efetiva e eficiente, em um pais de infindáveis carências sociais, desigualdades e exclusões (Lefèvre, 1983, 1987, 1995, 1997; V.C. Oliveira, 1995; Rondelli, 1995).

É a isto que Thomas (1975, p. 88, citado por Capra, 1982, pp. 133-134) se refere, quando afirma que:

Ao ver televisão, temos a impressão de vivermos acuados, sob um risco total, cercados por todos os lados de micróbios sedentos de seres humanos, escudados contra a infecção e a morte graças unicamente a uma tecnologia química que nos permite continuar a matá-los antes que nos invadam. Somos convencidos a pulverizar desinfetantes por toda parte.... Aplicamos antibióticos potentes em arranhões leves e vedamo-los com tirinhas de plástico. O plástico é o novo protetor; embrulhamos os copos já de plástico dos hotéis em mais plástico e selamos os assentos dos sanitário como se fossem segredos de Estado, depois de esparzi-los com luz ultravioleta. Vivemos num mundo onde os micróbios estão tentando sempre atingir-nos, despedaçar-nos célula por célula, e só continuamos vivos às custas da diligência e do medo.

Promove-se, por parte dos mídias, o mito das tecnologias em saúde, enquanto uma promessa miraculosa para aliviar o sofrimento humano, curar o mal estar-social, melhorar o ambiente, estender a capacidade comunicacional das pessoas ou indicar formas de cuidar do corpo e combater doenças como realizações de interesse público. Contudo, não se nomeia ou se identifica a voz que o promove, como por exemplo, o complexo industrial-farmacêutico, de serviços ou de equipamentos médicos que, direta ou indiretamente, estão relacionados com a saúde. É assim que a mitificação das tecnologias em saúde se caracteriza como uma estrutura de comunicação que universaliza o particular e abole a complexidade das coisas, com a finalidade de naturalizar o seu significado, promovendo o consumo e projeção individual (V.C. Oliveira, 1995). 
Contudo, o próprio V.C. Oliveira (1995) alerta:

os mídias não são responsáveis sozinhos pela construção deste imaginário que fantasia a importância do desenvolvimento tecnológico. A escola e a própria ciência, entre outras instituições da modernidade, são igualmente responsáveis por difundir uma falsa ideia de que, para todo e qualquer problema, há uma solução tecnológica. Quer o problema seja de natureza política, psicológica ou ecológica, a primeira reação dos governos e dos institutos científicos é abordá-lo aplicando ou desenvolvendo alguma nova tecnologia (p. 29).

[...] torna-se evidente que o discurso dos mídias desloca o problema da tecnologia para a dimensão da novidade, isto é, as tecnologias e as técnicas passam a ser tratadas como algo novo, que supostamente amplia a capacidade de se lidar com os problemas humanos, sociais e naturais (p. 31).

É também a esta questão que se refere Giddens (1991), em sua obra As Consequências da Modernidade, quando alerta que todos nos tornamos vítimas do fascínio pela tecnologia, ou seja, um dos traços principais das implicações globalizantes do industrialismo é a difusão mundial das tecnologias de máquina. O impacto do determinismo tecnológico é claramente não limitado à esfera de produção, mas afeta muitos aspectos da vida cotidiana, bem como influencia o caráter genérico da interação humana com o meio ambiente material. Somos levados a crer que "a tecnologia determina a natureza do nosso sistema de valores e de nossas relações sociais, em vez de reconhecer que é justamente o inverso, isto é, que são nossos valores e relações sociais que determinam a natureza da tecnologia" (V.C. Oliveira, 1995, p. $30)$.

Para Rondelli (1995), a televisão, por exemplo, privatiza o tema saúde, ou seja, "toma algo que é do interesse público como objeto de contornos a serem oferecidos pelos interesses privados, não só aqueles da televisão, mas daqueles outros, também privados, organizados em torno da mídia, agenciando-a como o espaço onde se amplificam outros discursos aliados" (p. 46). Ou seja, a mídia trata as questões de saúde a partir dos seus próprios critérios de relevância, que não coincidem com os anseios de uma política pública de saúde equânime e universal.

V.C. Oliveira (1995) salienta que, se sintonizarmos a televisão no programa Fantástico, da rede Globo, perceberemos como sutilmente surge a razão autoritária da tecnologia, naturalizada no fomento ao consumo, travestida a partir da dicotomia entre o certo e o errado.

A doença aparece como errado, o desvio, o aspecto negativo da vida; a saúde como o certo. O discurso é tão envolvente e convincente que não deixa nada para se discutir ou pensar. E é curioso notar que tanto o combate à doença como a promoção da saúde estão sempre relacionados a alguma aparelho tecnológico, a alguma invenção ou ao desenvolvimento de uma nova técnica, os quais sempre vêm acompanhadas da voz competente de um expert (uma 
voz fundante), que pode ou adquiriu o direito de interpelar e/ou informar o público sobre a solução dos problemas de saúde e de outras coisas (p. 35).

De sorte que o programa Globo Repórter, também da rede Globo, que frequentemente toma algumas doenças como tema de relatos dramáticos - "entrevistando pessoas afetadas, especialistas que explicam o mal e as possibilidades de evita-lo ou de curá-lo, as possíveis consequências avassaladoras para a humanidade e o despreparo da medicina para resolvê-lo tão cedo" (Rondelli, 1995, p. 42) - vai ao ar, normalmente, às sextas feiras à noite, tendo assim, menor audiência. Pois, já é mais que suficiente aos usuários e gestores da área da saúde terem que "enfrentar" a Febre do Fantástico. Doença transmissível, que se caracteriza por grande número de usuários do Sistema Único de Saúde que, nas primeiras horas das segundas-feiras, procuram às Secretarias de Saúde, tamanha "eficácia simbólica" dessas matérias, para solicitar - ou exigir seu direito - aos procedimentos ou medicamentos, que na maioria das vezes nem aprovados para consumo humano estão, mas tendo sido noticiados como possível solução ou prevenção de um mal, igual ao que eles estão sentindo, torna-se absurdo, passível de denúncia ao judiciário, qualquer negativa de tal procedimento ou medicamento por parte do serviço público.

São vários os programas que trazem elaborações discursivas sobre a saúde. Tais programas como os exemplificados anteriormente empregam "os recursos da imagem gerada pela câmera televisiva que disseca corpos, cirurgias, trabalho e angústias da equipe médica, explicações sobre doenças, prognósticos, diagnósticos e comportamento dos familiares, fazendo dos relatos fontes de ação pedagógica e de histórias dramáticas e espetacularizadas" (Rondelli, 1995, p. 43).

Aproveitando o ensejo de comemoração dos 50 anos da rede Globo, momento em que dirigimos a atenção para os meios de comunicação, podemos observar que houve, nas últimas décadas, um extraordinário aperfeiçoamento técnico dos meios de se traduzir a vida em imagens, até ser possível, como no momento atual, dominar toda a extensão da vida social. A análise mais cuidadosa da relação entre os meios de comunicação e a saúde, com escopo na forma como o discurso televisivo se apropria da saúde, da doença, da tecnologia, do risco, do medo e do corpo, demonstra que estes aparecem como elementos importantes de muitos e diversificados investimentos de consumo.

Baudrillard (2011) e Debord (2003) afirmam que, desta forma, o sistema social em que vivemos possui a capacidade de integrar em si mesmo a sua própria negação, através do processo de simulação, dos produtos do espetáculo. Tudo é absorvido pelo sistema. Tudo é 
incorporado aos objetivos do mercado e apresentado de forma fantástica pelo mundo do espetáculo.

A partir desta breve descrição e análise da transformação da saúde em mercadoria, em uma sociedade capitalista, globalizada e virtualizada, podemos inferir que na modernidade, a tecnologia, a informática, a globalização, os meios de comunicação, a simulação e o espetáculo, aparecem como lugar de amplificação do conceito de reificação em Lukács (1974), não se conseguindo ver nada além da mercadoria.

\title{
1.4 Direito à saúde no Brasil: fetiche frente a prevalência da lógica do mercado
}

\author{
"No conceito moderno, saúde é um direito \\ fundamental do cidadão, que gera, também, para \\ ele e para a coletividade onde vive, obrigações $e$ \\ deveres de participação"
}

Hélio Pereira Dias, Direito Sanitário

Brasil, 2015: a "crise" do sistema de saúde brasileiro está presente em nosso cotidiano e pode ser constatada por qualquer pessoa da nossa sociedade através de fatos amplamente conhecidos e divulgados por diversos meios de comunicação: prontos-socorros lotados com pacientes pelo chão, ausência de redes assistências e de prestadores de serviços, epidemia de dengue, longas filas de espera, falta de leitos, carência de equipamentos, medicamentos e profissionais (especialmente médicos), falta de estrutura física, (sub)financiamento, precarização do trabalho, privatizações, etc.

Problemas semelhantes na assistência à saúde do país já aconteciam nos idos anos 70, quando teve início o processo de reforma do sistema de saúde brasileiro, mais conhecido como Reforma Sanitária. Também naquela época a população brasileira já sofria com as longas filas, falta de medicamentos, falta de leitos, pacientes pelo chão dos prontos-socorros, doenças que reemergiam sem controle (meningite, sarampo, cólera, difteria, tuberculose, etc.), desnutrição; alcoolismo, altas taxas de mortalidade infantil, falta de vigilância sanitária, maustratos sofridos por pacientes psiquiátricos nos hospitais especializados e a falta de acesso da 
população ao mínimo de assistência à saúde (Baptista, 2005; Bertolli Filho, 2002; Finkelman, 2002).

Apesar da convergência nas denúncias, é consenso na literatura que o cenário que compõe o pano de fundo dessas duas fases da saúde pública no Brasil é bastante diferente. Como principal diferença destaca-se o reconhecimento de que a inscrição do Sistema Único de Saúde (SUS) no texto constitucional, em 1988, representou uma importante inflexão no padrão de intervenção do Estado na questão saúde. Antes do SUS, a saúde não era um direito de todos, muito menos uma responsabilidade do Estado e estava restrita a uma parcela da população trabalhadora que pagava para garantir esse benefício, em uma espécie de seguro social privado (Baptista, 2005; Bertolli Filho, 2002; Finkelman, 2002; Mendes, 1999; Senna, A.M. Costa, \& L.N. Silva, 2010).

Deste modo, para a compreensão da propalada “crise” do sistema público de saúde no Brasil, faz-se necessário o resgate dos determinantes sócio-históricos das políticas de saúde, com enfoque a partir do início da intervenção do Estado, desvendando alguns momentos decisivos à própria concepção de saúde que se tem na atualidade.

No século passado, o sistema de saúde brasileiro transitou do "sanitarismo campanhista" (final do século XIX até 1965) para o "modelo médico-assistencial privatista", chegando, no final dos anos 80, ao modelo plural, hoje vigente, que inclui, como subsistema público de saúde, o SUS (Mendes, 1994, 1999).

As primeiras iniciativas de intervenção do Estado no setor saúde se deram entre o final do século XIX e primeiras décadas do século XX, no bojo da economia capitalista exportadora cafeeira, pautadas em um modelo de assistência médica voltado para "campanhas sanitárias" de forte cunho repressor, destinadas a combater as epidemias urbanas e, mais tarde, as endemias rurais (Baptista, 2005; Bertolli Filho, 2002; Bravo, 2006; Finkelman, 2002; Luz, 1991; Mendes, 1994, 1999; Sarreta, 2009).

Por todo período em que a economia brasileira esteve dominada pelo modelo agroexportador, "o que se exigia do sistema de saúde era, sobretudo, uma política de saneamento dos espaços de circulação das mercadorias exportáveis e a erradicação ou controle das doenças que poderiam prejudicar a exportação" (Mendes, 1999, p. 58).

Segundo Luz (1991), com o modelo sanitarista campanhista" "consolidou-se uma estrutura administrativa de saúde centralista, tecnoburocrática, corporativista e ligada a um corpo médico em geral proveniente da oligarquia de origem agrária que dominou a Primeira

12 "Modelo, de inspiração norte-americana, mas importado de Cuba, tornou-se um dos pilares das políticas de saúde no Brasil e no continente americano em geral" (Luz, 1991, pp. 78-79). 
República” (p. 79). Os serviços eram estabelecidos em uma relação vertical, "com imposição de normas e segregação social, em que os técnicos detinham o saber científico e desconsideravam o conhecimento popular, principalmente dos pobres e dos negros, considerados incapazes de compreender as causas das doenças ou de ter direitos" (Sarreta, 2009, p. 134).

$\mathrm{Na}$ década de 20, o Estado brasileiro sofria mais agudamente a crise do padrão agroexportador capitalista. Os países importadores tornavam-se cada vez mais exigentes com a qualidade dos produtos e as epidemias prejudicavam as relações econômicas do país, fazendo com que companhias de navegação evitassem os portos brasileiros (Baptista, 2005; N.R. Costa, 1985).

Além das inúmeras revoltas populares, do crescimento da massa trabalhadora urbana, composta em grande medida, como se sabe, por mão de obra estrangeira, das greves sucessivas, das epidemias, dos movimentos anarquistas e comunistas pressionando por ações mais efetivas do Estado na atenção à saúde, entrou um outro elemento em jogo no complexo causal dos acontecimentos dos anos 20, a saber, a pressão dos países capitalistas centrais sobre os periféricos "no sentido de que todos, em bloco, enfrentassem mais ativamente a problemática social e trabalhista nos marcos do capitalismo. Ou seja, rompendo com a postura liberal frente a estas questões, onde, como no Brasil, ela ainda imperava" (J.A.A. Oliveira \& Teixeira, 1985, p. 49).

Foi a partir destes movimentos que, em 1923, promulgou-se a chamada Lei Elói Chaves (Decreto n. 4.682, de 24/01/1923), que regulamentava a criação das Caixas de Aposentadorias e Pensões (CAPs) para algumas organizações trabalhistas mais atuantes política e financeiramente, como os ferroviários, marítimos e estivadores. Observa-se que estas categorias de trabalhadores, além de mais combativas, eram também estratégicas para a economia do país e diretamente ligadas ao processo de produção e reprodução de mercadorias, no cerne de um modelo econômico agroexportador fortemente assentado na monocultura cafeeira (Baptista, 2005; Behring \& Boschetti, 2009; Bravo, 2006; Mendes, 1994; J.A.A. Oliveira \& Teixeira, 1985).

No que diz respeito à abrangência das Caixas de Aposentadorias e Pensões dos anos 20, vale destacar que a Lei Elói Chaves deveria ser aplicada para todos os trabalhadores, mas de acordo com o Conselho Nacional de Secretários de Saúde [CONASS] (2011a):

Para que fosse aprovada no Congresso Nacional, dominado na sua maioria pela oligarquia rural, foi imposta a condição de que esse benefício não seria estendido aos trabalhadores rurais. Fato que, na história da previdência do Brasil, perdurou até a década de 1960, quando 
foi criado o Funrural. Assim a lei foi aprovada, contemplando somente o operariado urbano (p. 13).

As CAPs eram organizadas por empresas privadas, administradas e financiadas por empresários e trabalhadores, em uma espécie de seguro social que tinha como atribuição central, permanente e obrigatória, a assistência médica. Nem toda empresa oferecia a possibilidade de formação de uma CAPs, de modo que só os grandes estabelecimentos tinham condições de formá-las e mantê-las (Baptista, 2005; Bravo, 2006; CONASS, 2011a; Mendes, 1994; Sarreta, 2009). De acordo com J.A.A. Oliveira e Teixeira (1985), o estado em nada contribuía financeiramente e não tinha responsabilidade na administração dessas Caixas, sua atuação restringiu-se à legalização de uma organização que já funcionava de maneira informal desde 1910 e, quando necessário, na mediação de possíveis conflitos de interesse.

Note-se que com a Lei Elói Chaves de 1923, emergiram, para uma pequena parcela dos trabalhadores do país, as primeiras práticas sistemáticas de assistência à saúde. Até aquele momento, no Brasil, havia apenas, uma atuação eventual, efetivada de maneira repressiva em situações de saneamento e epidemias em centros urbanos. Assim, o "Direito à Saúde” estava restrito, nesse período, à condição de categorias de trabalhadores segurados, diga-se de passagem, um seguro privado (Baptista, 2005).

Em 1929 a crise mundial afeta a economia da indústria cafeeira no Brasil. As condições de pobreza e a falta de trabalho determinam o êxodo da população rural para as cidades. A Revolução de 1930 afasta do poder os fazendeiros de café de São Paulo, provocando o fim do sistema político da Primeira República (1889-1930). Ocorre um realinhamento das elites no poder. Com o gaúcho Getúlio Vargas no governo, inicia-se o processo de maior intervenção do Estado na sociedade e na economia (Baptista, 2005; CONASS, 2011a).

A partir de então, de acordo com Fiori (1995, p. 59),

movido pelas necessidades da crise ou das pressões corporativas, apoiado na argumentação keynesiana e sustentado pelas social-democracias, o Estado redefiniu suas funções e reorganizou-se institucionalmente. Envolveu-se crescentemente na manutenção de níveis de investimento compatíveis com as exigências de emprego e consumo das populações, na sustentação de expectativas estáveis, na negociação das margens de lucro, na alavancagem das fronteiras tecnológicas e, sobretudo, depois de 1945, na promoção maciça de políticas de bemestar e promoção social.

Ou seja, o Estado assume ativamente o papel de regulador da economia e começa a dar maior prioridade e incentivo a indústria. "Investe nas áreas de siderurgia, energia e 
transportes, implantando uma infraestrutura produtiva, absorvendo a mão-de-obra advinda do campo e alavancando a economia nacional" (Baptista, 2005, p. 18).

No plano social, compreendendo a conjuntura de ascendência e hegemonia do Estado populista, observa-se a estatização da previdência social. As antigas CAPs são substituídas gradualmente pelos Institutos de Aposentadoria e Pensões (IAPs). Nesses institutos, os trabalhadores eram organizados por categorias profissionais, não mais por empresas. O Estado passa a ter responsabilidade no financiamento e principalmente na administração dos IAPs (Cohn, 2002, 2005; CONASS, 2011a; Finkelman, 2002; J. A.A. Oliveira \& Teixeira, 1985).

Da mesma forma como ocorreu com as CAPs, os institutos, criados a partir dos anos 30, favoreceram camadas de trabalhadores urbanos mais aguerridas em seus sindicatos e fundamentais para a economia agroexportadora até então dominante. O primeiro instituto criado foi o dos Marítimos (IAPM), em 1933 e o último o dos Ferroviários e Empregados em Serviços públicos (IAPFESP), em 1953 (Finkelman, 2002; Luz, 1991; Mendes, 1994; Sarreta, 2009).

No que diz respeito à abrangência dos Institutos de Aposentadorias e Pensões, pretendeu-se "estender para um maior número de categorias do operariado urbano os seus benefícios, como forma de 'antecipar' reivindicações destas categorias e não proceder uma cobertura mais ampla" (Bravo, 2006, p. 5). Os trabalhadores que não contribuíssem com os Institutos estavam excluídos do sistema de proteção e consequentemente sem assistência à saúde. Portanto, estavam excluídos os trabalhadores rurais, os profissionais liberais, os que exerciam atividades informais, aqueles cujas ocupações não tivessem sido reguladas por lei, bem como os pobres e os desempregados, ou seja, todos aqueles que não se encontravam habilitados a usufruir os serviços oferecidos pelos IAPs. Para esses grupos, a assistência médica era prestada pelo atendimento de caridade e filantrópico, mantido pela igreja (Baptista, 2005; CONASS, 2011a; Sarreta, 2009).

De acordo com J.A.A. Oliveira e Teixeira (1985), no período dos IAPs, o modelo previdenciário brasileiro, principalmente, entre os anos 30 e 45, foi orientado por uma lógica "intencionalmente contencionista", determinada pelo rápido crescimento da massa trabalhadora inserida e maior preocupação com a acumulação de capital do que com a ampla prestação de serviços. Para os autores, pela análise da legislação previdenciária da época é possível observar o deslocamento da assistência médico-hospitalar de uma posição central para uma função secundária e restritiva. A legislação dos IAPs, ao contrário do período das CAPs, procurou demarcar bem a diferença entre "Previdência" e "Assistência Social", definindo limites orçamentários máximos para as despesas com assistência médico-hospitalar 
e farmacêutica e criando a prática de convênios com instituições privadas para a compra de serviços médico-hospitalares.

Assim, a Previdência Social, graças ao "regime de capitalização" implantado com os IAPs, foi se transformando, aos poucos, em uma sócia privilegiada do Estado e das empresas estatais, como um elemento importante para um dos projetos econômicos centrais do governo no período, ou seja: o apoio à industrialização (Mendes, 1994; J.A.A. Oliveira \& Teixeira, 1985).

No que diz respeito à assistência à saúde, para o período, observa-se que a ação do Estado formalizava uma distinção institucional entre duas áreas: de um lado a saúde pública, de caráter preventivo, conduzida por meio de campanhas do Ministério da Educação e Saúde; do outro, a assistência médica, de caráter curativo, conduzida por ações da previdência social por meio dos IAPs. Tal dualidade marcaria definitivamente as ações de saúde no Brasil (CONASS, 2011a; Sarreta, 2009).

Para Luz (1991), até a primeira metade do século XX, podemos observar:

Centralismo, verticalismo e autoritarismo corporativo, do lado da saúde pública; clientelismo, populismo e paternalismo, do lado de instituições de previdência social, incluindo as de atenção médica. ...traços que configuram o perfil autoritário que ainda hoje caracteriza, em grande parte, o conjunto das instituições de saúde pública e dos sistemas de decisões em política de saúde no Brasil (pp. 79-80).

Note se que, o período de 1945 a 1964, foi marcado por grandes mudanças. O Brasil vivencia um rápido processo de industrialização, que determina o deslocamento do polo dinâmico da economia para os centros urbanos, gerando uma grande massa operária que necessitava ser atendida pelo Sistema de Saúde. O importante, já não era sanear os espaços, mas atuar sobre o corpo do trabalhador, mantendo e restaurando sua capacidade produtiva (Mendes, 1994).

O sanitarismo campanhista já não correspondia às necessidades de uma economia industrializada. Desta forma, sob influência norte-americana, "observou-se um movimento simultâneo de crescimento da atenção médica da Previdência Social e de esvaziamento progressivo das ações campanhistas que acabou por levar à conformação e hegemonização, na metade da década de 60, do modelo médico-assistencial privatista" [itálicos nossos] (Mendes 1999, p. 59).

A política de saúde que se expande nessa fase é a de ampliação do âmbito de ação da Previdência Social, que sob a influência norte-americana e forte centralidade administrativa, 
imprime uma concepção de planejamento em saúde, no sentido de efetivar investimentos priorizando a iniciativa privada, seguindo o modelo de saúde norte-americano ${ }^{13}$.

De acordo com Sarreta (2009), no período dos IAPS as reformas e construções de hospitais com tecnologia de alto custo abriram espaço para o fortalecimento da indústria farmacêutica e de equipamentos hospitalares, representando o privilegiamento do setor privado e da assistência médica, de caráter curativo, conduzida por ações da previdência social. Bravo (2006) destaca, que a partir dos anos 50, a estrutura para atendimento hospitalar já estava montada e indicava a formação das empresas médicas: "A corporação médica ligada aos interesses capitalistas do setor era, no momento, a mais organizada e pressionava o financiamento através do Estado, da produção privada, defendendo claramente a privatização" (p. 5) [itálicos nossos]. Entretanto, apesar das pressões, de acordo com a autora, a assistência médica previdenciária até 1964 foi fornecida basicamente pelos serviços próprios dos Institutos de Aposentadorias e Pensões.

Sublinha-se que, o conceito chave que permite entender o sistema de proteção social instituído entre 1930 e 1964, seja o de "cidadania regulada”, cujas raízes encontram-se em um sistema de estratificação ocupacional definido por norma legal, em que "a cidadania está embutida na profissão o os direitos do cidadão restringem-se aos direitos do lugar que ocupa no processo produtivo, tal como reconhecido por lei. Tornam-se pré-cidadãos, assim, todos aqueles cuja ocupação a lei desconhece" (V.G. Santos, 1979, p. 75).

O período a seguir compreende os vinte anos de ditadura militar (1964-1984), que se caracterizou pelo controle do Congresso Nacional e do Poder Judiciário, negação violenta dos direitos civis e políticos, forte censura, ausência de eleições, centralização administrativa, repressão e tortura aos opositores do governo, considerados subversivos por lutarem, de forma armada ou não, pela derrubada dos sistemas autoritários e sua substituição pelo governo democrático e/ou socialista (Bertolli Filho, 2002; Cohn, 2005; Faleiros, 2000; Ministério da Saúde, 2006b).

${ }^{13}$ O capítulo escrito por Noronha e Ugá (1995) “é dedicado à análise do caso paradigmático do modelo de sistema de saúde baseado no seguro-privado, ardorosamente defendido, a partir dos anos 80, por importantes atores sociais como a panaceia para a organização da atenção da saúde em vários países” (p. 177). Atualmente no Brasil, o modelo americano, é novamente defendido pelo atual presidente da Câmara, o deputado Eduardo cunha (PMDB-RJ), que desarquivou a PEC 451/2014, de sua autoria. Na prática, esta PEC obriga as empresas a pagarem planos de saúde privados para todos os seus empregados, retirando do Estado a responsabilidade de oferecer saúde como direito universal e transferindo tal responsabilidade para o setor privado. As consequências da aprovação desta PEC, caso ocorra, serão com certeza devastadoras ao SUS e ao direito universal à saúde. É no mínimo lamentável, que no Brasil ainda prosperem teses já condenadas na pátria exemplar do neoliberalismo econômico. 
Na primeira parte deste período, ou seja, de 1964 a 1974, que coincide, com o "milagre econômico brasileiro", de acordo com Luz (1991), se estabeleceu no Brasil uma política de saúde diferente em relação aos dois modelos anteriores, caracterizada por uma síntese nova e perversa, que reorganizou os traços institucionais do "sanitarísmo campanhista" (oriundo da Primeira República) e os do "modelo curativo da atenção médica previdenciária" (do período populista), em uma estratégia de medicalização social sem precedentes na história do país.

"A medicalização da vida foi imposta, tanto na Saúde Pública quanto na Previdência Social. O setor saúde precisava assumir as características capitalistas, com incorporação das modificações tecnológicas ocorridas no exterior” (Bravo, 2006, p. 6). “A saúde passou então a ser vista como um bem de consumo. Especificamente, um bem de consumo "médico", [itálicos nossos] (Luz, 1991, p. 82).

Nesse período, a primeira ação significativa no sistema de previdência brasileiro ocorreu em 1966 com a unificação e concentração dos IAPs em uma única estrutura, o Instituto Nacional de Previdência Social (INPS) ${ }^{14}$. O INPS concentrou todas as contribuições previdenciárias do país, permitindo uma uniformização dos benefícios que, nos IAPs, eram bastante diferenciados (Baptista, 2005; CONASS, 2011a; Sarreta, 2009). “A criação do INPS foi o momento institucional de consolidação do modelo médico-assistencial privatista" (Mendes, 1999, p. 59).

Segundo J.A.A. Oliveira e Teixeira (1985), o modelo de assistência médica implantado, com a criação do INPS, foi o de privilegiamento do produtor privado dos serviços de saúde, cujas características marcantes foram:

a) A extensão da cobertura previdenciária de forma a abranger a quase totalidade da população urbana e ainda parte da população rural (p. 207);

b) A orientação da política nacional de saúde para o privilegiamento da prática médica curativa, individual, assistencialista e especializada, em detrimento de medidas de saúde pública, de caráter preventivo e de interesse coletivo (p. 208);

c) A criação de um complexo-médico-industrial, responsável pelas elevadas taxas de acumulação do capital das grandes empresas monopolistas internacionais na área de produção de medicamentos e de equipamentos médicos (p. 209);

\footnotetext{
14 Vale destacar que o processo criação do INPS, com incorporação, centralização e uniformização dos benefícios não se deu sem a resistência daqueles contribuintes de institutos com mais benefícios. Com a unificação, a assistência dos institutos mais ricos podia também ser usufruída pelos contribuintes de outros institutos, que contribuíam com valores menores e que não recebiam uma assistência de boa qualidade em seus institutos de origem. Tal fato ocasionou uma migração de pacientes de alguns institutos para outros, gerando superlotação de alguns hospitais, filas, demora no atendimento e insatisfação geral (Baptista, 2005). Para Mendes (1994), delineava-se, o processo que se consolidaria na década de 80 como "universalidade excludente" das políticas de saúde.
} 
d) O desenvolvimento de um padrão de organização da prática médica orientada em termos da lucratividade do setor saúde propiciando a capitalização da medicina e privilegiamento do produtor privado destes serviços (pp. 214-215).

Seguindo esta lógica, até 1974, a política proposta pelo INPS levou a inclusão de novas categorias profissionais no sistema (trabalhadores rurais, empregadas domésticas e autônomos), a cada nova categoria inclusa o Estado respondia ao aumento da demanda com a contratação de serviços privados, fortalecendo o "complexo médico-empresarial". Generalizou-se a demanda social por consultas médicas como resposta às graves condições de saúde e elegeu-se a medicina hospitalar como sinônimo de cura e de restabelecimento da saúde individual e coletiva. A saúde pública, historicamente relegada a segundo plano, tornou-se uma máquina ineficiente e conservadora, cuja atuação restringia-se a campanhas de baixa eficácia. Com o financiamento da Previdência Social, observa-se a intensificação de construções e reformas de inúmeras clínicas e hospitais privados; concomitantemente ocorre a multiplicação de faculdades particulares de medicina por todo o país (Baptista, 2005; CONASS, 2011a; Luz, 1991).

A este respeito, Luz (1991) destaca:

Assistimos também ao desenvolvimento de um ensino médico desvinculado da realidade sanitária da população, voltado para a especialização e a sofisticação tecnológica e dependente das indústrias farmacêuticas e de equipamentos médico-hospitalares. Assistimos, finalmente, à consolidação de uma relação autoritária, mercantilizada e tecnificada entre médico e paciente e entre serviços de saúde e população (p. 82).

Note-se que o subsistema de saúde hegemônico era o 'privado contratado' com a Previdência Social, que cobria os beneficiários daquela instituição. Este subsistema cresceu induzido por 'políticas de terceirização' da atenção médica que criaram um mercado cativo na área da Previdência Social. De tal forma que, no período de 1969 a 1984, os leitos privados subiram de 74.543 para 348.225 , um crescimento da rede privada de $467 \%$, conformador de um sistema de atenção hospitalocêntrico [itálicos nossos] (Mendes, 1994, 1999).

Entretanto, em 1975, o modelo econômico implantado pela ditadura militar entra em crise. Os trabalhadores com baixos salários, contidos pela política econômica e pela repressão, passam a conviver com a inflação, dívida externa acentuada, desemprego e suas graves consequências sociais, como aumento da marginalidade, das favelas, da desnutrição e da taxa de mortalidade infantil. Com o fim do "milagre econômico" o sistema de proteção social entra em colapso (CONASS, 2011a; Finkelman, 2002; Sarreta, 2009) e o modelo médicoassistencial privatista - representado na época por sua organização símbolo, o Instituto 
Nacional de Assistência Médica e Previdência Social (INAMPS), criado em 1977 - começa a mostrar suas mazelas:

a) A prática médica dominante, a flexneriana, baseada nos aspectos curativos reabilitadores, não era capaz de alterar os perfis de morbimortalidade;

b) Os custos crescentes desse modelo inviabilizavam sua expansão;

c) A ausência de critérios para compra de serviços dos hospitais privados era incompatível com uma ação racionalizadora da rede privada;

d) $\mathrm{O}$ modelo dual ${ }^{15}$ gerava superposições, descoordenações e ausência de controle (S.F. Teixeira, 1989, citado por Mendes, 1994, p. 31).

Todos esses efeitos e consequências fizeram emergir, entre 1975 e início dos anos 80, uma grande insatisfação popular em relação à "política de saúde da ditadura". Nesse contexto, sindicatos das diversas categorias profissionais da saúde, principalmente, médicos, acadêmicos, cientistas e tecnocratas progressistas debatiam em seminários e congressos nacionais e internacionais as epidemias, as endemias e a degradação da qualidade de vida do povo. Este movimento pela transformação do setor saúde fundiu-se com outros movimentos sociais - compreendendo associações de moradores de bairros e favelas, movimentos de mulheres, sindicatos, Igreja e partidos políticos progressistas - que tinham em comum a luta pelos direitos civis e sociais percebidos como dimensões imanentes à democracia. Em um contexto de luta política entre projetos sanitários alternativos ${ }^{16}$, os serviços de saúde se tornaram o foco da crise do modelo de política social vigente (Escorel, D.R. Nascimento, \& Edler, 2005; Luz, 1991; Mendes, 1994, 1999).

Finkelman (2002) resume assim o que caracteriza o final da década de 70 até metade dos anos 80:

A crise econômica teve duplo efeito. Por um lado, agravou a distribuição da renda e a qualidade de vida da população, o que aumentou as necessidades de atenção à saúde; por outro, diminuiu as receitas fiscais e as contribuições sociais, com impacto sobre o volume de recursos destinados à saúde. Nesse cenário, consolidou-se no país o movimento pela Reforma Sanitária, cujas principais bandeiras eram: 1) a melhoria das condições de saúde da população; 2) o reconhecimento da saúde como direito social universal; 3) a responsabilidade

\footnotetext{
${ }^{15}$ Para Mendes (1994), enquanto o Programa de Pronta Ação (PPA) financiava a ampliação do atendimento de urgência a toda a população, abrindo um mercado cativo para o setor privado; o Fundo de Apoio ao Desenvolvimento Social (FAS) garantia uma expansão física adicional com recursos subsidiados para também atender ao setor privado, especialmente no incremento da área física hospitalar de serviços de alta densidade tecnológica. Desta forma, o setor privado “fornecedor de serviços de saúde” era duplamente beneficiado.

${ }^{16}$ Estavam em disputa três grandes projetos políticos na sociedade (concebendo projeto político como conjunto de crenças, interesses e concepções que orientam a ação política dos sujeitos): 'o projeto autoritário', 'o projeto neoliberal' e o 'projeto democrático-participativo'. No Brasil, a partir da queda do regime militar, a disputa permaneceu de forma mais intensa entre o projeto neoliberal e o democrático-participativo. As características de ambos podem ser encontradas nos embates políticos, econômicos e sociais que se seguem no fim do século XX até a atualidade (Dagnino, Olvera, \& Panfichi, 2006, citados por Borlini, 2010).
} 
estatal na provisão das condições de acesso a esse direito; 4) a reorientação do modelo de atenção, sob a égide dos princípios da integralidade da atenção e da equidade; 5) a reorganização do sistema com a descentralização da responsabilidade pela provisão de ações e serviços.

A construção de sólida aliança política em torno dessas teses foram legitimadas, em 1986, na VIII Conferência Nacional de Saúde (CNS). As sete primeiras conferências haviam sido eventos técnicos, com presença seletiva de especialistas, em sua maioria vinculados ao Ministério da Saúde e à problemática sanitária de responsabilidade dessa agência. A VIII CNS não só ampliou a participação de outros segmentos técnicos, sobretudo da previdência social, como incluiu ampla representação de usuários dos serviços de saúde (p. 246).

A discussão sobre os caminhos e diretrizes da reforma sanitária continuaram ao longo dos anos de 1987 e 1988, envolvendo grupos de esquerda, contra aqueles conservadores neoliberais. As divergências eram nítidas, não apenas entre esses grandes setores de base, mas também entre os grupos de esquerda, que competiam muitas vezes por posições e situações de controle dentro do aparelho de Estado, permitindo, em diversos momentos, que assuntos de vocação particular orientassem os de vocação geral e de interesse público (Luz, 1991).

Ao mesmo tempo ocorria a discussão da Assembleia Nacional constituinte, que apesar de incorporar um conjunto de conceitos, princípios e diretivas extraídos da prática corrente e hegemônica, tomaria como base o relatório da VIII CNS para propor uma nova lógica organizacional referida pela reforma sanitária. Assim, o Sistema Único de Saúde (SUS) foi finalmente aprovado e inscrito na Constituição Federal de 1988 (Baptista, 2005; Mendes, 1994).

Desta forma, ao contrário do que a expressão "Sistema Único" dá a entender, no final dos anos 80, consolidou-se, com a criação do SUS, um sistema plural e segmentado de saúde, composto por três subsistemas: o subsistema público único e universal - SUS, o subsistema de atenção médica supletiva e o subsistema de desembolso direto, sendo os dois últimos, sistemas privados de saúde (Mendes, 1994, 1999, 2001).

Para Mendes (1994, p. 47), “o texto da saúde na Constituição, apesar de suas ambiguidades, representou um avanço considerável, refletindo a correlação de forças presentes na sociedade brasileira e permitindo a continuidade da luta política entre os projetos neoliberal e da reforma sanitária".

No texto constitucional, a saúde insere-se em um contexto mais amplo da política pública, o da seguridade social, que conforme artigo 194 da Constituição Federal, "compreende um conjunto integrado de ações de iniciativa dos Poderes Públicos e da sociedade, destinadas a assegurar os direitos relativos à saúde, à previdência e à assistência social" [itálicos nossos] (Constituição da República Federativa do Brasil, 1988, p. 115). Para Baptista (2005), a definição do modelo de seguridade social no Brasil significou a 
formulação, pela primeira vez na história do país, de uma estrutura de proteção social abrangente, justa, equânime e democrática, que rompe definitivamente com o padrão político excludente/regulado dos períodos anteriores.

Com sua constitucionalização, a saúde passava a ser, conforme artigo 196 da constituição: “direito de todos e dever do Estado, garantido mediante políticas sociais e econômicas que visem à redução do risco de doença e de outros agravos e ao acesso universal e igualitário às ações e serviços para sua promoção, proteção e recuperação" [itálicos nossos] (Constituição da República Federativa do Brasil, 1988, pp. 116-117).

Vale destacar que, embora a saúde faça parte do Sistema de Seguridade Social, ao lado da Previdência e da Assistência Social, a mesma possui características próprias, pois se pauta pelo princípio da universalidade, com pretensão de atender a todos os cidadãos. De outra forma, a previdência social se baseia na contribuição com filiação obrigatória, já a assistência social requer carência de recursos, ainda que independente de qualquer contribuição. Nesse seguimento, a saúde se constitui em ações e serviços disponibilizados a toda e qualquer pessoa sem exigência de contraprestação (Serrano, 2012).

Com efeito, com a Constituição Cidadã, conquistava-se o direito à participação e pela primeira vez em décadas, falava-se na definição de um sistema protetor com garantia do direito à saúde integral.

No relatório da VIII Conferência Nacional de Saúde, que serviu de referência na discussão da Assembleia Nacional Constituinte em 1987/88, definiu-se:

Saúde como Direito - em seu sentido mais abrangente, a saúde é a resultante das condições de alimentação, habitação, educação, renda, meio ambiente, trabalho, transporte, emprego, lazer, liberdade, acesso e posse da terra e acesso a serviços de saúde. É, assim, antes de tudo, o resultado das formas de organização social da produção que podem gerar grandes desigualdades nos níveis de vida.

Direito à saúde - significa a garantia, pelo Estado, de condições dignas de vida e de acesso universal e igualitário às ações e serviços de promoção, proteção e recuperação de saúde, em todos os seus níveis, a todos os habitantes do território nacional, levando ao desenvolvimento pleno do ser humano em sua individualidade (Ministério da Saúde, 1986, p. 4).

A constitucionalização do SUS como garantia institucional fundamental determina que a efetivação do direito à saúde deveria "conformar-se aos princípios e diretrizes pelos quais foi constituído, estabelecidos primordialmente pelos artigos 198 a 200 da Constituição Federal, dos quais se destacam a unidade, a descentralização, a regionalização, a hierarquização, a integralidade e a participação da comunidade" (Sarlet \& M.F. Figueiredo, 2009, p. 37). 
A partir da constitucionalização do subsistema público de saúde em 1988, iniciaram-se os debates e as negociações em torno da lei regulamentadora deste subsistema. Conhecida como Lei Orgânica da Saúde (LOS 8.080), esta lei visava regulamentar e definir com maior nível de detalhamento os objetivos e atribuições do SUS, aprofundando o debate das questões do financiamento, da participação do setor privado, da descentralização, regionalização, hierarquização do sistema e da participação popular (Baptista, 2005; CONASS, 2011a, 2011b).

Após 390 dias de tramitação no Congresso Nacional, em 19 de setembro de 1990, a lei 8.080 foi parcialmente aprovada, sofrendo vetos do então presidente Fernando Collor de Mello, principalmente, nos aspectos relativos ao financiamento, participação popular, organização da estrutura ministerial e da política de cargos e salários (Baptista, 2005).

Tal fato desencadeou intensa reação de entidades da sociedade civil, levando a aprovação, em 28 de dezembro de 1990, da Lei 8.142, que complementaria a Lei 8.080/90, dispondo sobre a participação da comunidade na gestão do SUS e sobre as transferências intergovernamentais de recursos financeiros (Baptista, 2005; Mendes, 1999).

Com efeito, pelo conjunto das Leis 8.080, de 19 de setembro de 1990 e 8.142, de 28 de dezembro de 1990, estava regulamentado o Sistema Único de Saúde brasileiro. A Lei 8.080/90, “dispõe sobre as condições para a promoção, proteção e recuperação da saúde, a organização e o funcionamento dos serviços correspondentes e dá outras providências" (CONASS, 2011b, p. 42). Já a Lei 8.142/90, “dispõe sobre a participação da comunidade na gestão do Sistema Único de Saúde (SUS) e sobre as transferências intergovernamentais de recursos financeiros na área da saúde e dá outras providências” (CONASS, 2011b, p. 61).

Essas duas Leis, denominadas em conjunto de Lei Orgânica da Saúde (LOS), baseadas nos preceitos constitucionais, determinam os princípios e diretrizes do SUS, dos quais destacamos: universalidade, equidade ${ }^{17}$, integralidade (como princípios doutrinários); descentralização, regionalização, hierarquização, resolubilidade, complementariedade do setor privado e participação popular (como princípios organizativos) (CONASS, 2011b; Ministério da Saúde, 1990).

\footnotetext{
${ }^{17}$ Vale destacar que o conceito de equidade em saúde foi incorporado posteriormente a promulgação do SUS e não figura em nenhum dos textos do arcabouço legal (Constituição da República Federativa do Brasil de 1988, Lei 8.080/90 e Lei 8.142/90). O conceito é representado na Lei 8.080/90 pelo princípio IV do art. $7^{\circ}$ : "igualdade da assistência à saúde, sem preconceitos ou privilégios de qualquer espécie" (CONASS, 2011b, p. 45). Entretanto o termo é melhor conceituada como o combate às desigualdades, como um princípio para se fazer justiça social, ou seja, canalizando maior atenção e recursos aos que mais necessitam (Escorel, 2008).
} 
No que se refere à participação popular, a Lei Orgânica da Saúde 8.142/90, estabelece duas formas de participação da comunidade na gestão do SUS: as 'Conferências' e o 'Conselhos de Saúde'. As Conferências são fóruns amplos, onde se reúnem, a cada 4 anos, representantes dos vários seguimentos sociais: usuários do SUS (em maior ou menor intensidade), profissionais de saúde, representantes do governo, prestadores de serviços de saúde, parlamentares, membros do judiciário e outros, para "avaliar a situação de saúde e propor as diretrizes para a formulação da política de saúde nos níveis correspondentes" (CONASS, 2011b, p. 61).

Os Conselhos de saúde são órgãos $\operatorname{colegiados}^{18}$, de caráter permanente e deliberativo, compostos por representantes do governo, prestadores de serviços, profissionais de saúde e usuários do SUS, atuando na formulação de estratégias, no controle e na fiscalização da execução da política de saúde, inclusive em seus aspectos financeiros (CONASS, 2011b; Ministério da Saúde, 2001).

De acordo com o Ministério da Saúde (2001),

com a participação da comunidade na gestão do SUS estabelece-se uma nova relação entre o Estado e a Sociedade, de forma que as decisões do Estado sobre o que fazer na saúde terão que ser negociadas com os representantes da sociedade, uma vez que eles são quem melhor conhecem a realidade de saúde das comunidades. Por isso a participação social é entendida como uma das formas mais avançadas de democracia [itálicos nossos] (p. 81).

Previa-se a democratização das ações de saúde por meio da participação dos usuários nos conselhos e conferências, o controle social autorizava a influência da população na "gestão"19 do SUS e possibilitava as ações do Estado na direção dos interesses da coletividade (Sarreta, 2009).

Entretanto, o que vai caracterizar fundamentalmente as políticas de saúde na década de 90, é o seu desenvolvimento em um contexto de profunda crise econômica e sua coincidência com o processo de redemocratização e liberalização da economia, marcados pelo fenômeno da Globalização, o qual determina mudanças importantes nas relações sociais (Fiori, 1990; Ministério da Saúde, 2006b; Sallum Júnior, 2003).

${ }^{18}$ Conforme deliberação da IX Conferência Nacional de Saúde, a Resolução CNS no 33/92 define a constituição dos Conselhos com a seguinte composição: $50 \%$ de usuários, $25 \%$ de trabalhadores de Saúde e $25 \%$ de governo e prestadores de serviços (Guizardi et al., 2004; Ministério da Saúde, 1992, 2002).

19 A gestão ou ação administrativa pressupõe o desenvolvimento de um processo que envolve as funções planejamento, organização, direção e controle, segundo os preceitos do direito e da moral, visando ao bem comum (CONASS, 2011c). Nos municípios, os gestores são as Secretarias Municipais de Saúde ou as Prefeituras, sendo responsáveis pelas mesmas, os respectivos Secretários Municipais de Saúde e Prefeitos (Ministério da Saúde, 1990). 
Assiste-se ao redirecionamento do papel do Estado, influenciado pelo processo de ajuste neoliberal. No entanto, é na segunda metade dos anos 90 que praticamente se completa o projeto mais acabado (e neoliberal) de "Reforma do Estado" 20 , caracterizada pela ampliação do assistencialismo e do clientelismo, por um esvaziamento da estratégia reformista e pelo desmonte da capacidade orçamentária e administrativa de intervenção do Estado no campo social (Behring, 2008; Bravo, 2006; Cordeiro, 2001; Finkelman, 2002; Noronha \& Soares, 2001; Sallum Júnior, 2003).

De acordo com Sallum Júnior (2003), o governo tratou de construir novas formas de regulamentar o mercado, seguindo um sistema multifacetado de ideias, cujo denominador comum era o neoliberalismo. Para o autor, as características centrais desse ideário podem ser assim resumidas:

O Estado deveria transferir quase todas as suas funções empresariais para a iniciativa privada; teria que expandir suas funções reguladoras e suas políticas sociais; as finanças públicas deveriam ser equilibradas e os incentivos diretos às companhias privadas seriam modestos; haveria também restrição aos privilégios existentes entre os servidores públicos; e o país deveria intensificar sua articulação com a economia mundial, embora dando prioridade ao Mercosul e às relações com os demais países sul-americanos (p. 44).

Ocorre desta maneira a "contrarreforma" do Estado sugerida pelos neoliberais, voltada aos interesses do mercado, compatível com os ideais econômicos, na contramão dos anseios democráticos e progressistas, que, definitivamente, inviabilizaram o pleno desenvolvimento dos princípios do SUS e da Seguridade Social (Behring, 2008; Borlini, 2010; Bravo, 2006; Cordeiro, 2001; Noronha \& Soares, 2001; Sallum Júnior, 2003).

A partir da contrarreforma, inicia-se uma tendência à desresponsabilização do Estado em relação à política social, sendo esta repassada gradativamente a um suposto "setor público não estatal" (também chamado de Terceiro Setor) representado pelas organizações sociais, ONGs e entidades filantrópicas, seguindo o trinômio neoliberal: privatização, focalização e descentralização (Behring, 2008; Behring \& Boschetti, 2009; Mendes, 1994; Montaño, 2010; Noronha \& Soares, 2001).

“Assim, no plano das políticas sociais, reforma passa a significar a revisão radical do acesso a certos bens sociais requeridos pela efetivação dos direitos sociais, em benefício do império da racionalidade e da globalização das economias nacionais" (Elias, s.d., p. 3).

\footnotetext{
${ }^{20}$ Behring (2008), destaca o uso indevido ou "apropriação indébita" (p. 128) do termo reforma pelos adeptos da corrente neoliberal, vez que o Estado desenvolvimentista, em tempos de hegemonia do neoliberalismo na condução das políticas econômicas, teria que ser reformado no sentido contrário às mudanças propostas pela constituição de 1988. Nesse sentido, uma verdadeira contrarreforma, tendo em vista o objetivo de assegurar a hegemonia do projeto neoliberal.
} 
"O cidadão, sujeito de direitos, passou a contribuinte-cliente, com pouca voz e nenhum voto nas agências reguladoras e pouco poder nos conselhos. A defesa da competitividade foi o eixo do discurso oficial e da legislação aprovada" (Ministério da Saúde, 2006b, p. 161).

Para Sarreta (2009):

O que se observa é a mercantilização da vida e da saúde determinada pela conjuntura econômica, o poder do mercado fortalece cada vez mais a hegemonia do capital. Esse movimento de mercantilização repercute na saúde e confronta diretamente com as propostas do SUS e, do mesmo modo, contribuiu para a transformação dos espaços políticos em espaços de mercantilização: onde tudo tem preço e compra quem pode (pp. 86-87).

No que diz respeito ao Sistema Único de Saúde brasileiro, podemos afirmar que o neoliberalismo teve influência direta na sua concepção e organização e, também tem influência sob os muitos interesses que envolvem a implementação das políticas de saúde ou ausência delas, aproximando-se ou distanciando-se dos usuários, para servir aos setores ligados à saúde privada (dentro da qual se destacam a indústria farmacêutica, a de equipamentos médicos e dos planos de saúde).

Em síntese, sem negar avanços, podemos observar que a trajetória de 27 anos do SUS é marcada por tensões entre as agendas da reforma sanitária e a da reforma do Estado de inspiração neoliberal, a qual têm orientado sua implementação. Salta aos olhos, a distância entre a "imagem-objetivo" projetada pela reforma sanitária e a atual realidade do Sistema Único de Saúde. Contrapõem-se desta maneira, a imagem de um sistema de saúde universal, equânime, resolutivo, com participação e controle social; à situação presente em que vivenciamos um SUS subjugado pela ideologia neoliberal, que não garante universalidade, que abre cada vez mais espaço ao mercado, que mantém um controle social fragilizado e cuja conquista do Direito à Saúde é um processo inacabado.

Nesse sentido, o Direito à Saúde no Brasil, historicamente se vê obrigado a curvar-se à soberania do mercado. Isso porque, o processo sócio-histórico de tentativa de afirmação de um sistema de saúde universal, equânime e resolutivo, se contrapõe aos anseios de um mercado implacável, que vê na atividade em saúde um setor altamente rentável e que pretende tudo comercializar. 
CAPÍTULO 2 - PERCURSO METODOLÓGICO 

Neste capítulo, abordaremos o percurso metodológico, ou seja, a caracterização do estudo, o local, os sujeitos, a técnica utilizada para coleta de dados, as questões éticas para realização do estudo e os procedimentos para análise de conteúdo.

\subsection{Caracterização do estudo}

"Neutralidade é uma postura farsante, por
ingenuidade ou por esperteza. Neutralidade é
truque, é golpe do cientista que pretende viver
tranquilamente à sombra do poder, sem "dor de
consciência”. Escamoteia sua condição histórica
de ator político, muito privilegiado numa
sociedade pobre de recursos e de saber
especializado"

Pedro Demo, Metodologias Cientificas em

Ciências Sociais

A busca da compreensão do objeto em foco circunscreve-se no campo da abordagem qualitativa (Minayo, 1998). Portanto, efetivamos um estudo exploratório (Triviños, 1987) de recorte empírico que buscou, sob a perspectiva dos entrevistados, examinar os determinantes sócio-históricos mais gerais ligados à saúde como mercadoria e os reflexos dessa racionalidade sob o Sistema Único de Saúde na Macrorregião Triângulo Sul/MG.

Esse tipo de abordagem permite um aprofundamento do tema proposto, considerando que o objeto investigado pertence a uma realidade ligada ao mundo dos significados, motivos, aspirações, crenças, valores e atitudes resultantes da ação humana objetiva, apreendidos por meio do cotidiano, da vivência e da explicação das pessoas que vivenciam determinadas situações não mensuráveis por uma fórmula numérica (Demo, 1995; Minayo, 1998; Piovesan \& Temporini, 1995; Pope \& Mays, 2005; Triviños, 1987).

Segundo Pope e Mays (2005), um dos pontos fortes da abordagem qualitativa é estudar as pessoas em seu ambiente natural, em seu próprio território e da interação entre elas, em sua própria língua, com seus próprios termos. 
O presente estudo é coerente nesta direção, uma vez que a temática e o objeto de investigação são frutos da vivência e interação dos sujeitos no processo de implementação do Sistema Único de Saúde, especialmente em um contexto descentralizado, regionalizado, hierarquizado e complexo como é o caso da saúde. O trabalho desenvolvido enfatiza a relação entre os Secretários de Saúde, Conselheiros Municipais de Saúde e os Usuários do Sistema Único de Saúde, subsidiada na análise do cotidiano local e regional da promoção da saúde.

Assim, encontramos na abordagem qualitativa o caminho para desenvolver esta investigação, na medida em que tal perspectiva dá abertura à apreensão da complexidade presente no campo da Saúde e permite trabalhar o objeto deste estudo com fundamentos que exigem a incorporação do “'significado' e da 'intencionalidade' como inerentes aos atos, às relações, e às estruturas sociais, sendo essas últimas tomadas tanto no seu advento quanto na sua transformação, como construções humanas significativas” (Minayo, 1998, p.10).

\subsection{Local do estudo}

Para Minayo (1998), "nada pode ser intelectualmente um problema, se não tiver sido em primeira instância, um problema da vida prática” (p. 90). Nesse sentido, com base na síntese de vivências realizadas no plano da saúde enquanto enfermeiro e ex-Secretário de Saúde de Sacramento/MG, pude observar empiricamente e reiteradamente, que as tentativas de implementação de um Sistema Único de Saúde universal, integral, equânime e resolutivo naquele município eram atravessadas por atributos presentes no processo de gestão nacional, estadual, regional e local, bem como pelas relações sociais de produção na região e em especial às da área de saúde.

Deste ponto de vista, posso afirmar, principalmente para os municípios de pequeno e médio porte e para alguns de grande porte populacional, que não há como organizar um sistema público de saúde local sem o estabelecimento de alianças com diversos atores intermunicipais e interestaduais envolvidos com a questão saúde. Por tanto, para este trabalho, o exame da prática em saúde, fundamentada na determinação das relações reificadas da ordem do capital, só poderia ser realizado considerando a dinâmica de uma região de saúde e sua imbricação com os arranjos da política pública de saúde, da política econômica e mecanismos institucionais operando nas relações intermunicipais e intergovernamentais da região. 
Desta forma, partindo da experiência vivenciada pelo doutorando e pela relativa proximidade desta região em relação à cidade de Ribeirão Preto $(170 \mathrm{~km})$, local de vínculo institucional do pesquisador, adotamos como lócus de estudo para essa pesquisa a Macrorregião Triângulo Sul do estado de Minas Gerais.

Em Minas, desde 2003, o Plano Diretor de Regionalização da Saúde (PDR/MG) é um dos componentes do projeto estruturador denominado "Regionalização da Atenção à Saúde", que integra o plano de governo do Estado. A construção do Plano Diretor de Regionalização (PDR) definiu espaços assistenciais regionais apenas dentro dos limites territoriais do Estado, embora seja de conhecimento geral a existência de fluxos assistenciais entre as Unidades Federadas. Portanto, a distribuição e delimitação dos espaços regionais do PDR mineiro estão embasadas em um modelo de atenção à saúde detalhado em uma tipologia de serviços, organizada conforme diferentes níveis de densidade tecnológica e agregação dos serviços que requerem economia de escala, mas desconsidera a regionalização ou pactuação entre unidades federadas, ou seja, entre estados (Malachias, Leles, \& Pinto, 2010).

Considerado como instrumento de planejamento e gestão, o PDR objetiva direcionar a descentralização com vistas à promoção de maior e adequada acessibilidade dos usuários, considerando os princípios da integralidade, equidade e economia de escala (Pestana, Tavares Júnior \& Mendes, 2009; Secretaria de Estado da Saúde de Minas Gerais [SES], 2012). De acordo com a Secretaria de Estado da Saúde de Minas Gerais, o propósito de um PDR da saúde é construir um dos pilares para estruturação e descentralização dos sistemas de cogestão e organização dos serviços de saúde em redes, tendo em vista possibilitar o direcionamento equitativo da implementação das políticas públicas de saúde. O PDR, portanto, estabelece uma base territorial e populacional para o cálculo das necessidades, da priorização na alocação dos recursos e da descentralização programática e gerencial (Malachias et al., 2010; Pestana et al., 2009; SES, 2012).

Com este objetivo, o espaço territorial mineiro dos 853 municípios foi recortado em 76 microrregiões e em 13 macrorregiões de saúde, de acordo com os princípios de economia de escala, qualidade e acesso (Malachias et al., 2010). Nesse sentido, o trabalho de campo que orientou esse estudo foi realizado em nove municípios que integram a Macrorregião Triângulo Sul (Figura 1), que de acordo com PDR é composta por 27 municípios divididos em três microrregiões, Frutal e Iturama (Figura 2), Uberaba (Figura 3) e Araxá (Figura 4). A população total da macrorregião estimada pelo Instituto Brasileiro de Geografia e Estatística [IBGE] (2014) foi de 752.948 mil habitantes. A macro possui uma área territorial de 35.534,7 $\mathrm{Km}^{2}$ e apresenta uma densidade demográfica de 21,18 habitantes $/ \mathrm{km}^{2}$. 


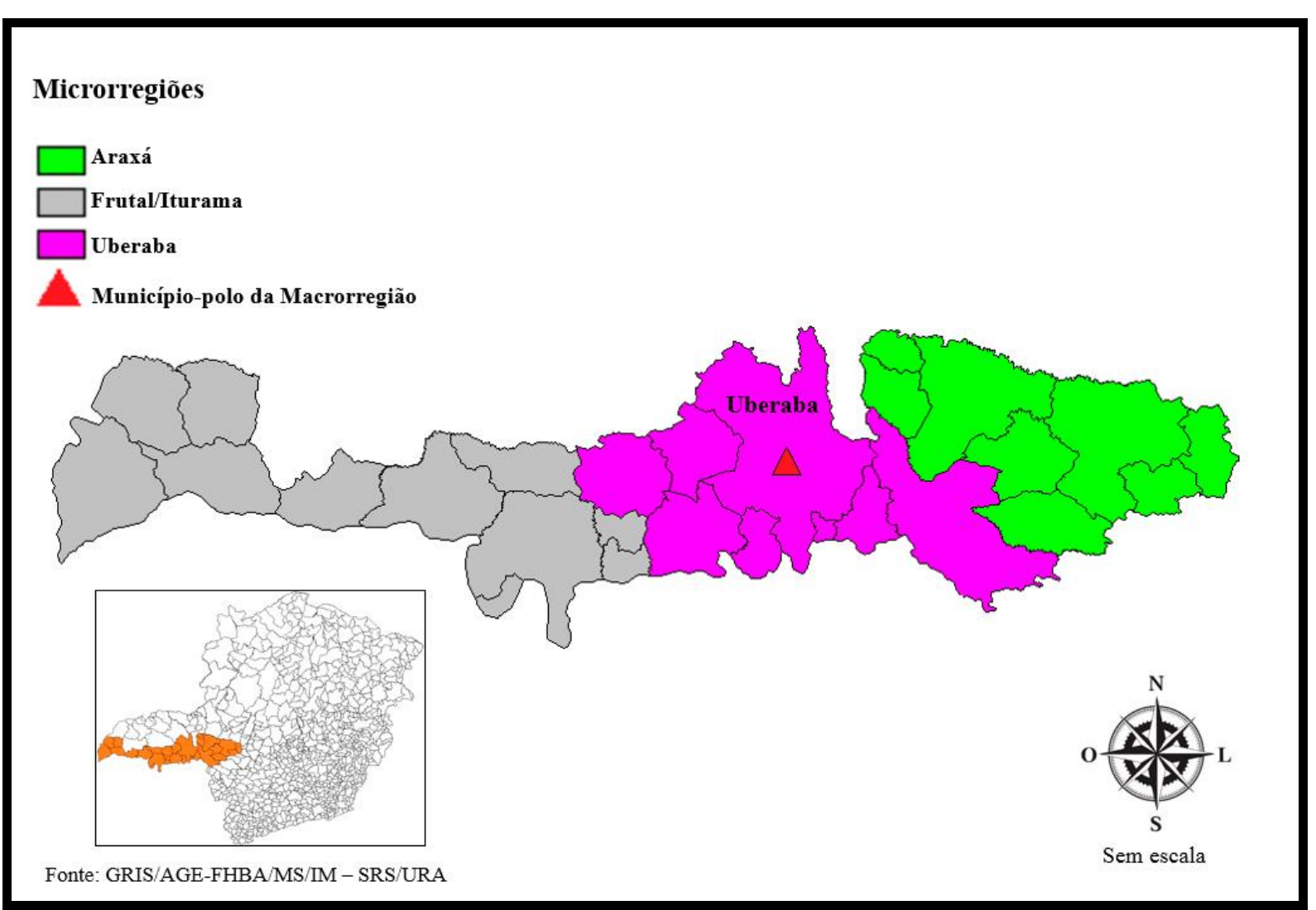

Figura 1. Mapa da Macrorregião assistencial Triangulo Sul e respectivas Microrregiões

$\square$ Municípios-polo da Microrregião

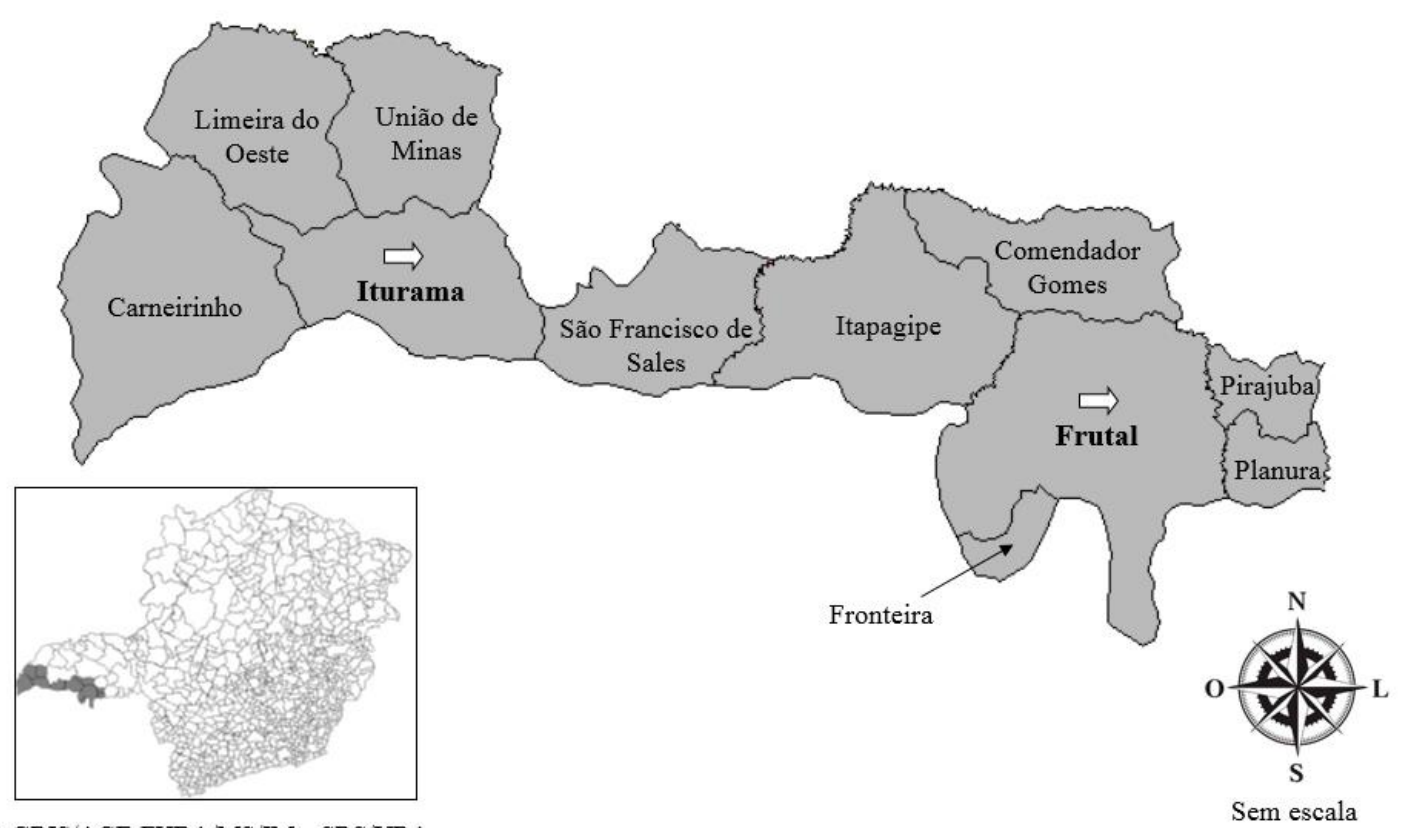

Fonte: GRIS/AGE-FHBA/MS/IM - SRS/URA

Figura 2. Mapa da Microrregião Frutal/Iturama 


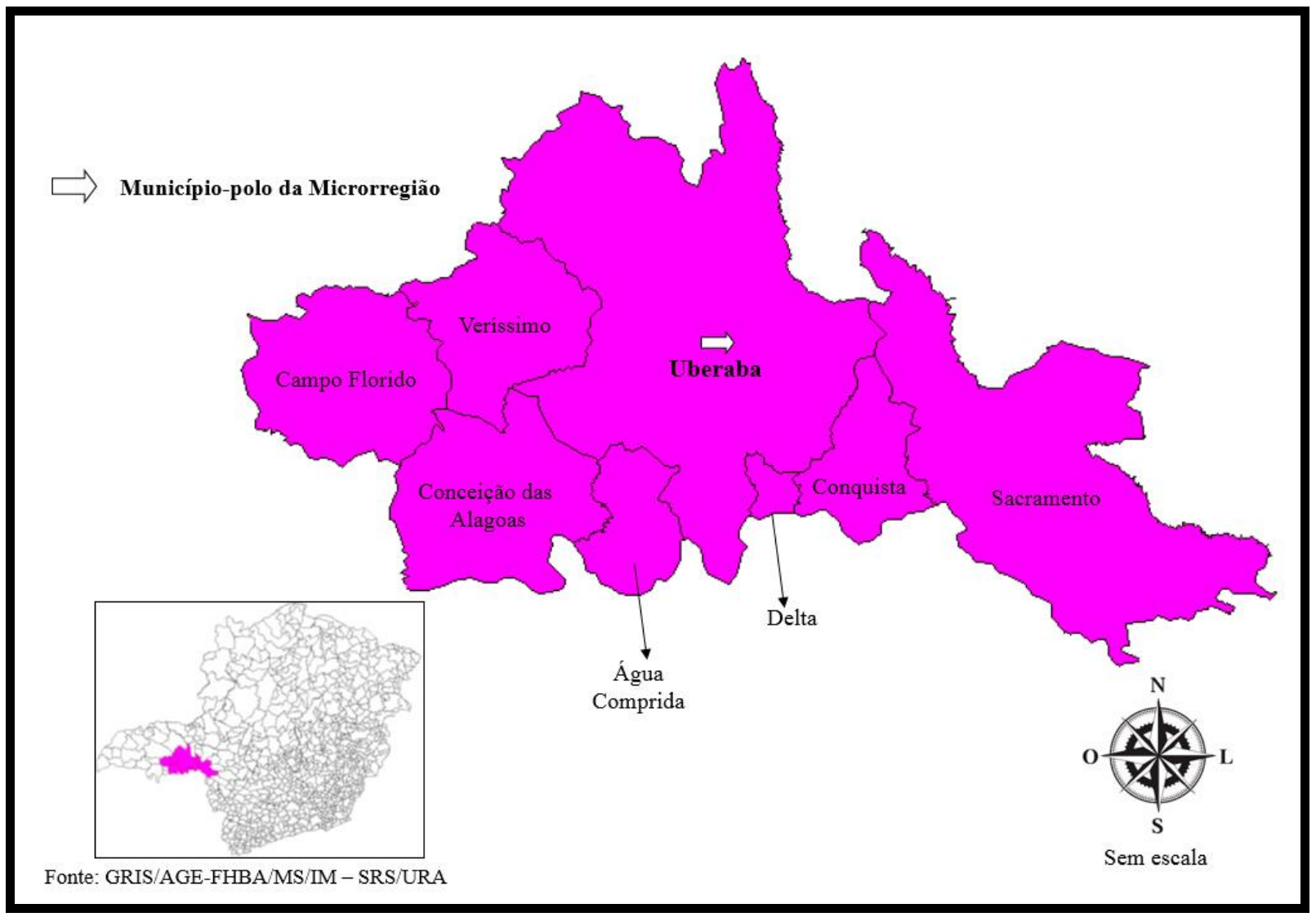

Figura 3. Mapa da Microrregião Uberaba

$\square$ Município-polo da Microrregião

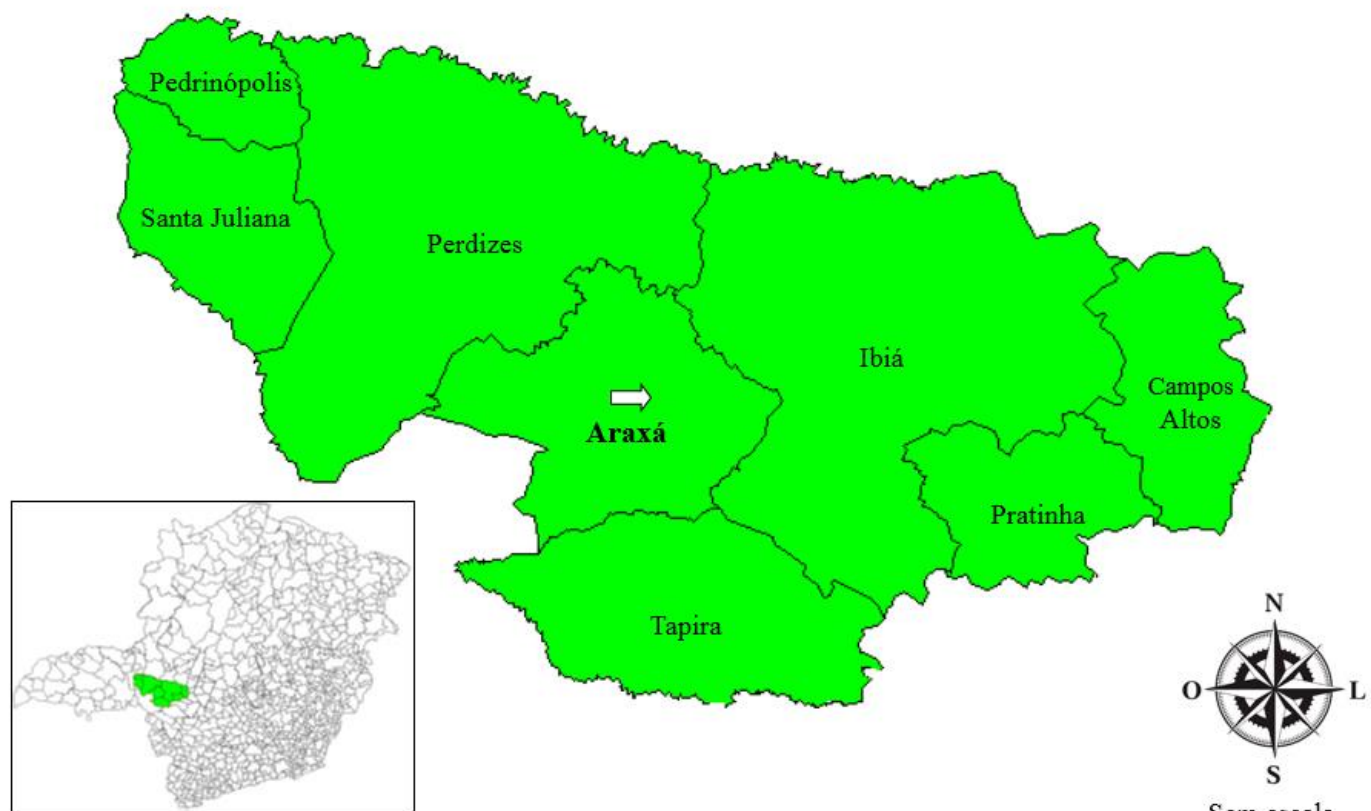

Fonte: GRIS/AGE-FHBA/MS/IM - SRS/URA

Sem escala

Figura 4. Mapa da Microrregião Araxá 
Em cada microrregião foram selecionados para o estudo o maior município em relação ao parâmetro populacional, um de médio porte e o de menor porte populacional, totalizando três municípios por micro e nove na macrorregião. Como o SUS se organiza de maneira regionalizada e hierarquizada, por níveis de complexidade assistencial, nossa escolha dos municípios se justifica por representar, em cada micro, os fluxos assistenciais ordenados entre os municípios, tanto do de baixa complexidade para o de alta ou vice e versa. Ou seja, esses municípios possuem características do todo ao qual pertencem, assim, por meio do estudo de suas determinações seria possível abordar a totalidade assistencial do SUS na região.

Consideramos, conforme IBGE (2011), municípios de médio porte aqueles com população entre 10.000 e 50.000 habitantes. Como em cada micro havia mais de um município nesta condição, fizeram parte de nosso estudo aqueles municípios sorteados por micro, dentre aqueles pertencentes ao parâmetro populacional acima especificada.

Dessa forma, após sorteio em cada microrregião dos municípios de médio porte, definiu-se os municípios participantes de nosso estudo (Figura 5), sendo eles, na Microrregião de Frutal/Iturama: Frutal (maior), Planura (médio porte) e Comendador Gomes (menor); na Microrregião de Uberaba: Uberaba (maior), Conceição das Alagoas (médio porte) e Água Comprida (menor); na Microrregião de Araxá: Araxá (maior), Ibiá (médio porte) e Pratinha (menor).

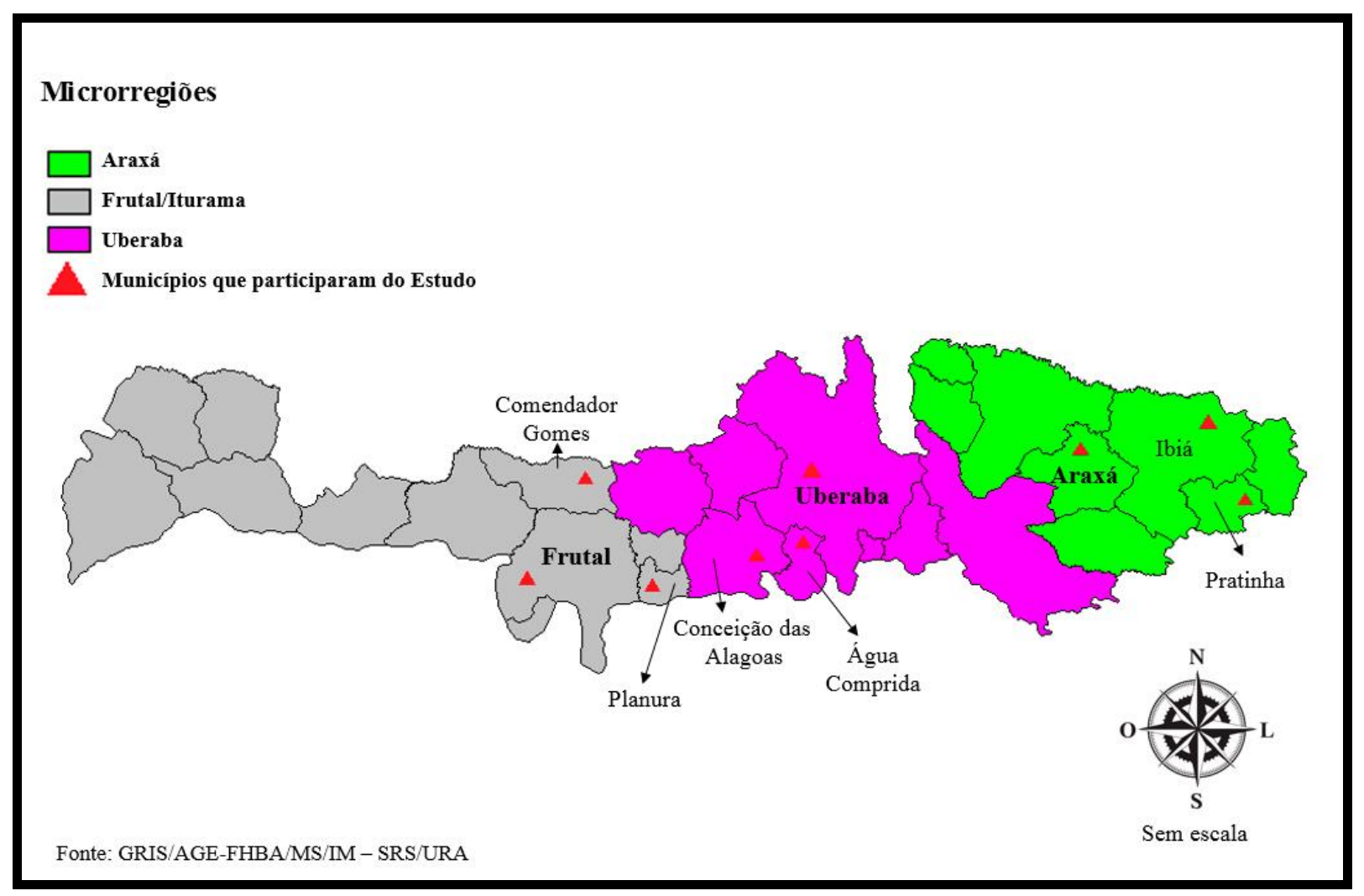

Figura 5. Mapa de localização dos municípios selecionados para o estudo 
$\mathrm{Na}$ Tabela 1 podemos observar a população residente em cada município e em sua respectiva microrregião.

Tabela 1

População residente estimada por municípios, microrregiões e Macrorregião Triângulo Sul, Minas Gerais, 2014

\begin{tabular}{|c|c|c|}
\hline Município/Microrregião & Pop/Total/Município & Pop/Total/Microrregião \\
\hline Carneirinho $(M F I)$ & 9.939 & \\
\hline Comendador Gomes (MFI)* & $3.105^{*}$ & \\
\hline Fronteira (MFI) & 16.036 & \\
\hline Frutal $(M F I)^{*}$ & $57.269 *$ & \\
\hline Itapagipe (MFI) & 14.645 & \\
\hline Iturama $(M F I)$ & 37.277 & 172.945 \\
\hline Limeira do Oeste (MFI) & 7.327 & \\
\hline Pirajuba (MFI) & 5.396 & \\
\hline Planura $(M F I) *$ & $11.355^{*}$ & \\
\hline São Francisco de Sales (MFI) & 6.110 & \\
\hline União de Minas (MFI) & 4.486 & \\
\hline $\operatorname{Araxá}(M A) *$ & $101.136^{*}$ & \\
\hline Campos Altos (MA) & 15.078 & \\
\hline Ibiá $(M A) *$ & $24.613 *$ & \\
\hline Pedrinópolis (MA) & 3.638 & \\
\hline Perdizes (MA) & 15.484 & 180.620 \\
\hline Pratinha $(M A) *$ & $3.485 *$ & \\
\hline Santa Juliana (MA) & 12.702 & \\
\hline Tapira (MA) & 4.484 & \\
\hline Água Comprida $(M U) *$ & $2.067 *$ & \\
\hline Campo Florido (MU) & 7.562 & \\
\hline Conceição das Alagoas (MU)* & $25.588 *$ & \\
\hline Conquista $(M U)$ & 6.860 & \\
\hline Delta $(M U)$ & 9.280 & 399.383 \\
\hline Sacramento (MU) & 25.432 & \\
\hline Uberaba $(M U)^{*}$ & $318.813 *$ & \\
\hline Veríssimo $(M U)$ & 3.781 & \\
\hline Total/Macrorregiãao & 752.948 & 752.948 \\
\hline
\end{tabular}

Legenda: MFI (Micro Frutal/Iturama), MA (Micro de Araxá) e MU (Micro de Uberaba). *Municípios que fizeram parte do estudo.

Fonte: IBGE (2014). 
Vale destacar que na Microrregião Uberaba não foi necessário realizar sorteio para o município de médio porte. Nesta região apenas dois municípios se enquadravam na especificação de parâmetro populacional definida anteriormente, mas como o pesquisador deste estudo ocupou o cargo de Secretário Municipal de Saúde do município de Sacramento até o dia 30 de agosto de 2011, optamos por excluir este município do sorteio para que não incorrêssemos em nenhum viés ético-metodológico, ficando desta forma, na Microrregião de Uberaba, apenas o município de Conceição das Alagoas, elegível para participar do estudo como município de médio porte.

\title{
2.2.1. Algumas características dos serviços de saúde dos municípios participantes e da Macrorregião
}

De acordo Malachias et al. (2010), o Plano Diretor de Regionalização da Saúde de Minas define:

\begin{abstract}
Macrorregião de Saúde - base territorial de planejamento da atenção terciária à saúde que engloba microrregiões de saúde (e seus municípios) em função da possibilidade de oferta e acesso a serviços de saúde ambulatoriais e hospitalares de maior densidade tecnológica: Alta Complexidade (AC) nos termos da Tabela do Ministério da Saúde (MS) - SIA e SIH (p. 64).

Polo Macrorregional - Município de maior densidade populacional da macrorregião, com estrutura de equipamentos urbanos e de saúde, de maior densidade tecnológica e que requer escala para cerca de 1.500 .000 habitantes; que exerce força de atração para micros circunvizinhas, polarizando todas ou a maioria das micros da macrorregião. Os municípios polo macro acumulam também a função de polo micro (p. 87).

Polo Microrregional - Município que recebe maior frequência absoluta e relativa de referência dos residentes na microrregião para os serviços ambulatoriais e hospitalares; oferta o maior percentual de clínicas/procedimentos do elenco ou da Carteira de Serviços Microrregional; de maior população e desenvolvimento atual e potencial, com capacidade de fixação de RH do nível assistencial (p. 65).
\end{abstract}

Posto isto, apresentamos neste espaço, algumas informações a fim de realizar uma breve caracterização da rede assistencial dos municípios participantes do estudo, bem como da Macrorregião de saúde.

Na tabela 2 observa-se a cobertura da Estratégia Saúde da Família (ESF) e a população “SUS dependente". 
Tabela 2

Cobertura da Estratégia Saúde da Família (ESF) e População SUS Dependente nos municípios participantes do estudo, Minas Gerais, 2010

\begin{tabular}{ccccc}
\hline \hline Município & $\begin{array}{c}\text { População } \\
\text { IBGE-2010 }\end{array}$ & $\begin{array}{c}\text { Pop. SUS } \\
\text { Dependente } \\
(\%)\end{array}$ & $\begin{array}{c}\mathbf{N}^{\mathbf{0}} \text { de Equipes } \\
\text { no Município } \\
(\mathbf{n})\end{array}$ & $\begin{array}{c}\text { Cobertura } \\
(\%)\end{array}$ \\
\hline \hline Frutal & $\mathbf{5 3 . 4 6 8}$ & $\mathbf{8 0 , 7 7}$ & $\mathbf{8}$ & $\mathbf{5 1 , 6 2}$ \\
Planura & 10.384 & 86,87 & 3 & 99,67 \\
Comendador Gomes & 2.972 & 97,03 & 1 & 100 \\
Araxá & & & & \\
Ibiá & 93.672 & 82,29 & 14 & 51,56 \\
Pratinha & 23.218 & 91,95 & 6 & $\mathbf{8 9 , 1 5}$ \\
& 3.265 & 97,47 & 1 & 100 \\
Uberaba & 295.988 & 79,66 & 50 & $\mathbf{5 8 , 2 8}$ \\
Conceição das Alagoas & 23.043 & 87,7 & 7 & 100 \\
Água Comprida & 2.025 & 97,32 & 1 & 100 \\
\hline \hline
\end{tabular}

Fonte: IBGE (2010a) e SES (2013).

A análise da tabela permite identificar baixa cobertura da ESF nos municípios polo de Macro e Microrregião.

São muitos os fatores que dificultam a implantação de equipes da ESF em municípios de médio e grande porte. F. Campos, Aguiar e V.B. Oliveira (2002) destacam alguns destes fatores como: os impactos na força de trabalho em saúde ativa, ou seja, a baixa aderência ao trabalho na ESF pelos profissionais residentes nestes municípios, especialmente os médicos, seja em virtude de uma formação pregressa privilegiadora da especialização ou subespecialização, seja em decorrência de terem que mudar um processo de trabalho já consolidado e conflitante com a proposta da ESF; os autores também destacam como Portela e Ribeiro (2011), a presença de uma rede de serviços de saúde diversificada e complexa, que pode estar competindo com a consolidação e estruturação da ESF e, por fim, relatam as dificuldades advindas da urbanização desordenada, como a de manutenção de equipes da ESF atuando em áreas sob o domínio de forças paralelas ao poder legalmente constituído, alicerçadas pelo tráfico de drogas e armas. 
Vale esclarecer que a expressão "População SUS Dependente", na Tabela 2, já há algum tempo está sendo vinculada à cobertura da ESF nos municípios. Na verdade, está é uma maneira reificada de naturalizar a "universalidade excludente", pois significa que quando em um determinado território o percentual da População SUS Dependente é baixo, ou seja, muitas pessoas têm planos de saúde, alega-se que este é um território de baixa vulnerabilidade social, de baixo risco e que, portanto, precisa de menor atenção do poder público.

Na Tabela 3 é possível observar, pelo menos em teoria, a possibilidade de expansão (calculada com base em parâmetros populacionais) do número de equipes e do número de Agentes Comunitários de Saúde (ACS) em cada município.

Tabela 3

Estrutura de Saúde da Família implantada e Teto para implementação/ credenciamento de equipes na APS em cada município participante do estudo, Minas Gerais, 2010

\begin{tabular}{|c|c|c|c|c|c|c|}
\hline \multirow[b]{2}{*}{ Município } & \multirow[b]{2}{*}{$\begin{array}{l}\text { População } \\
\text { IBGE/2010 }\end{array}$} & \multicolumn{5}{|c|}{ Teto e Credenciamento APS: UBS + ESF } \\
\hline & & $\begin{array}{c}\mathrm{N}^{0} \text { de } \\
\text { Unidades } \\
\text { de Saúde } \\
\begin{array}{c}\text { Implanta } \\
\text { das }\end{array}\end{array}$ & $\begin{array}{c}\text { Teto de } \\
\text { ESF/ESB } \\
\text { Para } \\
\text { Implanta } \\
\text { ção }\end{array}$ & $\begin{array}{c}\mathbf{N}^{0} \text { de ESF } \\
\text { Credencia } \\
\text { das no } \\
\text { Ministério }\end{array}$ & $\begin{array}{c}\text { ACS } \\
\text { Credencia } \\
\text { dos }\end{array}$ & $\begin{array}{c}\text { Teto de } \\
\text { Implant } \\
\text { ação } \\
\text { ACS }\end{array}$ \\
\hline Frutal & 53.468 & 15 & 22 & 8 & 56 & 135 \\
\hline Planura* & 10.384 & - & - & - & - & - \\
\hline Comendador & 2.972 & 2 & 1 & 1 & 7 & 7 \\
\hline Araxá & 93.672 & 20 & 39 & 14 & 123 & 237 \\
\hline Ibiá & 23.218 & 7 & 10 & 10 & 40 & 58 \\
\hline Pratinha* & 3.265 & - & - & - & - & - \\
\hline Uberaba & 295.988 & 35 & 125 & 60 & 420 & 748 \\
\hline Conceição & 23.043 & 10 & 10 & 7 & 41 & 59 \\
\hline Água Comprida & 2.025 & 2 & 1 & 1 & 4 & 5 \\
\hline
\end{tabular}

APS - Atenção Primária à Saúde; UBS - Unidade Básica de Saúde; ESF - Equipes de Saúde da Família; ESB - Equipes de Saúde Bucal; ACS - Agentes Comunitários de Saúde.

* Os dados de Planura e Pratinha não estavam disponíveis.

Fonte: SES (2013) 
Na Tabela 4, observa-se a distribuição dos leitos hospitalares dentre os municípios e na Tabela 5, o número de médicos cadastrados no Cadastro Nacional de Estabelecimentos de Saúde (CNES) em cada município participante do estudo.

Tabela 4

Distribuição dos Leitos Hospitalares e Complementares em cada município participante do estudo, Minas Gerais, 2015

\begin{tabular}{|c|c|c|c|c|c|c|c|}
\hline \multirow{2}{*}{ Município } & \multirow{2}{*}{$\begin{array}{l}\text { População } \\
2014\end{array}$} & \multicolumn{3}{|c|}{$\begin{array}{c}\text { Leitos Hospitalares } \\
\text { Gerais }\end{array}$} & \multicolumn{3}{|c|}{$\begin{array}{c}\text { Leitos Complementares } \\
\text { (UTI) }\end{array}$} \\
\hline & & Total & SUS & $\begin{array}{l}\text { Não } \\
\text { SUS }\end{array}$ & Total & SUS & $\begin{array}{l}\text { Não } \\
\text { SUS }\end{array}$ \\
\hline Frutal & 57.269 & 80 & 41 & 39 & - & - & - \\
\hline Planura & 11.355 & - & - & - & - & - & - \\
\hline Comendador & 3.105 & - & - & - & - & - & - \\
\hline Araxá & 101.136 & 257 & 182 & 75 & 19 & 17 & 2 \\
\hline Ibiá & 24.613 & 29 & 28 & 1 & - & - & - \\
\hline Pratinha & 3.485 & - & - & - & - & - & - \\
\hline Uberaba & 318.813 & 1008 & 632 & 376 & 137 & 67 & 70 \\
\hline Conceição & 25.588 & 21 & 21 & - & - & - & - \\
\hline Água Comprida & 2.067 & - & - & - & - & - & - \\
\hline
\end{tabular}

Fonte: CNES/DATASUS ${ }^{21}$; IBGE (2014).

UTI - Unidade de Terapia Intensiva

${ }^{21} \mathrm{http}: / / \mathrm{cnes}$. datasus.gov.br/Mod_Ind_Tipo_Leito.asp?VEstado=31\&VMun=317010 
Tabela 5

Número de médicos cadastrados no Cadastro Nacional de Estabelecimentos de Saúde (CNES) para cada município participante do estudo, Minas Gerais, 2015

\begin{tabular}{cc}
\hline \hline Município & Médicos Cadastrados no CNES \\
\hline Frutal & 95 \\
Planura & 8 \\
Comendador & 2 \\
Araxá & 175 \\
Ibiá & 37 \\
Pratinha & 5 \\
& \\
Uberaba & 853 \\
Conceição das Alagoas & 37 \\
Água Comprida & 2 \\
\hline \hline Total & 1214 \\
\hline \hline
\end{tabular}

Fonte: CNES/DATASUS ${ }^{22}$; IBGE (2014)

Em que pese o aparente alto número de leitos e de médicos, de acordo com a SES (2013), é prevalente, nos municípios da Macrorregião de saúde, a não atualização rotineira e contínua do CNES, que é a base operacional de planejamento das políticas de saúde regional e dos sistemas de informação, fato que dificulta o conhecimento da rede assistencial existente e não nos permite ter segurança na exatidão desses números.

Ainda de acordo com a SES (2013), dentre outras dificuldades, observa-se na região:

Fragmentação e desarticulação das redes de atenção à saúde, com fluxo assistencial desorganizado, inclusive nas situações de urgência e emergência, levando à população a deslocar-se para os municípios-polo das regiões em busca de atendimento, com consequente impacto financeiro e desperdício de recurso;

A realidade assistencial das redes psicossocial, de saúde bucal, de cuidados a pessoa com deficiência, de oftalmologia social, de urgência e emergência e viva vida, aquém do panorama ideal;

Credenciamentos pouco resolutivos junto ao SUS de prestadores que não cumprem integralmente o papel assistencial assumido mediante termo de compromisso/termo de metas/plano operativo anual;

A existência de muitos hospitais de pequeno porte, pouco resolutivos e com baixa capacidade de incorporação tecnológica;

Frequentes queixas de Gestores municipais relacionadas a dificuldades de atendimentos (consultas/exames) e/ou transferência de pacientes aos prestadores de média/alta complexidade (pp. 13-14).

\footnotetext{
${ }^{22}$ http://cnes.datasus.gov.br/Mod_Ind_Profissional_com_CBO.asp
} 
Por fim, de acordo com a SES (2013, p. 14), “a dificuldade dos municípios em prestar assistência integral à saúde da população, gera um aumento considerável de demandas judiciais" [itálicos nossos], como pode ser observado na tabela abaixo.

Tabela 6

Demandas judiciais da Macrorregião Triângulo Sul atendidas pelo Núcleo de Redes de Atenção à Saúde, Minas Gerais, 2013

\begin{tabular}{cccccccc}
\hline \hline & \multicolumn{3}{c}{ Medicamentos } & \multicolumn{5}{c}{ Procedimentos } \\
\cline { 2 - 7 } Ano & Mandados & $\begin{array}{c}\text { Ofício da } \\
\text { Promotoria }\end{array}$ & Solicitações & Mandados & $\begin{array}{c}\text { Ofícios da } \\
\text { Promotoria }\end{array}$ & Solicitações & Total \\
\hline \hline 2011 & 47 & 179 & 100 & 345 & 7 & 7 & 685 \\
2012 & 84 & 120 & 230 & 465 & 9 & 9 & 917 \\
Total & 131 & 299 & 330 & 810 & 16 & 16 & 1602 \\
\hline \hline
\end{tabular}

Fonte: SES (2013).

\subsection{Os Participantes do estudo}

Conforme citado anteriormente, com a Constituição de 1988, a participação da comunidade passa a ser um dos requisitos fundamentais para a implantação e consolidação do Sistema Único de Saúde (SUS). Em 1990, as publicações das Leis 8.080 e 8.142 determinam a institucionalização e regulamentação da participação popular e do Controle Social na gestão do SUS.

De acordo com Bispo Júnior, Messias e Sampaio (2006),

a concepção de gestão do SUS é essencialmente participativa e democrática. Nenhum gestor é senhor absoluto da decisão; ele deve ouvir a população e submeter suas intenções e ações à análise da sociedade para que, com base em uma avaliação coletiva, o conselho de saúde possa decidir qual a melhor política a ser implementada (p. 250).

Nessa perspectiva, em que pese a importância de se levar em consideração as experiências dos profissionais de saúde, dos prestadores de serviços, dos prefeitos, bem como de outros atores para a construção coletiva da prática de organização e planejamento dos serviços públicos de saúde, neste estudo, interessou-nos priorizar o ponto de vista de Secretários Municipais de Saúde, de Conselheiros Municipais de saúde (representantes dos 
usuários) e de Usuários do Sistema Único de Saúde, dada a relevância desses segmentos na engenharia institucional do SUS.

Cumpre salientar que um objeto científico nunca é passível de elucidação exaustiva no espaço cronológico e acadêmico de uma tese ou dissertação. Assim, para cumprir as exigências temporárias desse processo acadêmico, destacamos que a não inclusão de outros sujeitos sociais na análise deste estudo como os diversos profissionais da área da saúde, prefeitos, etc., não foi um esquecimento e sim uma opção metodológica, ou em outros termos, uma limitação do estudo.

A amostra, na abordagem qualitativa, não tem seu significado mais usual, de representatividade estatística (Pope \& Mays, 2005). Ela está mais ligada à significação e a capacidade que os sujeitos têm em oferecer informações confiáveis e relevantes sobre o tema em estudo (Duarte \& Barros, 2006).

Para Minayo (1998), o importante é que a amostra contenha e espelhe certas dimensões do contexto, algumas delas em contínua construção histórica. Como consequência, a amostragem qualitativa de acordo com a autora privilegia os sujeitos sociais que detêm os atributos que o investigador pretende conhecer e considera-os em número suficiente para permitir uma certa reincidência das informações.

Margarete Sandelowski (1995, citada por Turato, 2003, p. 361) traz uma observação elementar quanto o tamanho da amostra:

é a que permite - em virtude de não ser muito grande - a profundidade e a análise orientada para o caso, que é uma marca de todos os inquéritos qualitativos, e que resulta - em virtude de não ser muito pequena - em uma nova e rica tecida compreensão da experiência.

Desta forma, nossa amostra foi composta por 27 sujeitos, maiores de 18 anos, distribuídos conforme Figura 6 e intencionalmente selecionados pelo pesquisador em função de sua importância aos objetivos do estudo. 


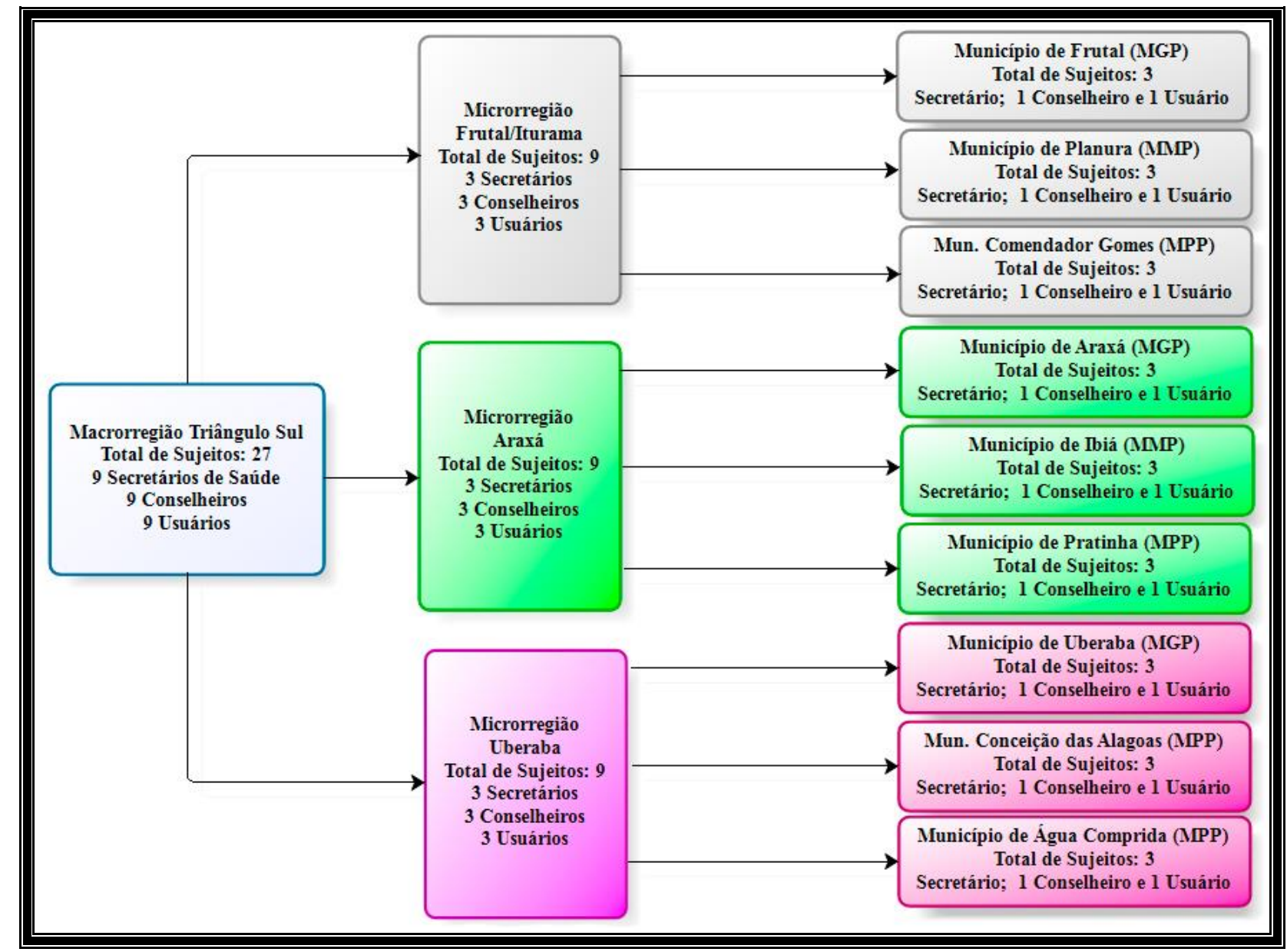

MGP - Município de Grande Porte populacional; MMP - Município de Médio Porte e MPP - Município de Pequeno Porte.

Figura 6. Organograma de distribuição dos sujeitos participantes do estudo por município, Microrregião e segmento que representam

\subsection{Coleta de dados}

Utilizamos como técnica de coleta de dados a entrevista semiestruturada, que de acordo com Triviños (1987) parte de certos questionamentos básicos, apoiados em pressupostos, que interessam à pesquisa, e que, em seguida, oferecem amplo campo de interrogativas, fruto de novos pressupostos que vão surgindo à medida que se recebem respostas do informante. "Desta maneira, o informante, seguindo espontaneamente a linha de seu pensamento e de suas experiências dentro do foco principal colocado pelo investigador, começa a participar na elaboração do conteúdo da pesquisa” (p. 146). 
Esta linha de raciocínio segue o que orientam Lüdke e André (1986) ao mencionarem que, neste tipo de entrevista, "o entrevistado discorre sobre o assunto proposto baseado nas informações que ele detém e que no fundo é a verdadeira razão da entrevista” (p. 33).

Desta forma, adotamos a técnica de entrevista semiestruturada desenvolvida por M.A. Figueiredo (1998) que preconiza a realização de etapas sucessivas, para minimizar a indução de conteúdos nas entrevistas. Com esta configuração, as entrevistas foram realizadas em dois momentos: um primeiro visando à aproximação com os participantes via rapport $^{23}$ e um segundo, onde se realizava a entrevista individual conforme procedimentos de evocação/enunciação/verificação, ambos descritos a seguir:

Rapport: momento inicial onde foram discutidas informações sobre a participação e as condições relevantes sobre a entrevista como a adesão espontânea, o Termo de Consentimento Livre e Esclarecido, a garantia de sigilo, autorização para filmar ou áudio-gravar a entrevista, a devolução dos resultados e o esclarecimento de dúvidas. Neste momento, também foram coletadas algumas informações para uma breve caracterização sociodemográfica (de cada seguimento dos sujeitos), abordando os seguintes aspectos: idade, sexo, estado civil, ocupação atual (para os não secretários de saúde), anos de estudo, formação, tempo de formação superior, curso de pós-graduação, área de conhecimento da pós-graduação, média salarial, há quanto tempo tem envolvimento com as questões da gestão do SUS, teve experiência anterior em algum cargo de gestão ou administração de serviços públicos, acúmulo de função, qual o vínculo empregatício (somente para os secretários), há quanto tempo é conselheiro (somente para os conselheiros) e por qual motivo procurou a unidade de saúde (apenas para os usuários).

1. Evocação: após o rapport, pedia-se à pessoa entrevistada que refletisse, por determinado tempo, sobre o que considerava mais importante no funcionamento/organização do SUS em seu município.

"Antes de iniciarmos nossa entrevista, gostaria que você pensasse, por alguns instantes, sobre os aspectos positivos e negativos do serviço Público de Saúde, o SUS. Procure pensar em tudo que você acredita importante, tanto coisas que podem ser positivas

\footnotetext{
23 "O rapport pode ser definido como um sentimento consciente de acordo, simpatia, confiança e responsividade mútua entre uma pessoa e outra" (Campbell, 1996, p. 607 citado por Turato, 2003, p. 327). Em uma linguagem comum, trata-se de "quebrar o gelo"; e na entrevista significa o momento em que pesquisador e entrevistado, após estudarem-se (involuntariamente) por alguns minutos, firmam um canal aberto e amigável em que transcorrerá uma interlocução mais espontânea (Turato, 2003).
} 
como negativas. Vou dar um tempo para você pensar, em silêncio, sobre isso e, quando terminar me avise". Certo?

2. Enunciação: após o entrevistado manifestar estar pronto para começar, o mesmo recebia lápis e papel e as seguintes instruções:

"Por favor, escreva agora, com suas próprias palavras, o quê de mais importante, tanto coisas que podem ser negativas como positivas, você pensou sobre o que pedi. Procure escrever da forma mais simples que puder" (Nos casos de dificuldades para a pessoa entrevistada redigir sua resposta, o entrevistador anotava ipsis litteris a narrativa do informante).

3. Averiguação: uma vez recolhidos os enunciados dos sujeitos, o entrevistador iniciava a entrevista propriamente dita, que consistia na verificação e discussão dos conteúdos evocados na primeira fase. A partir desse momento, o pesquisador informava que a entrevista estaria sendo gravada (filmada ou áudio-gravada, dependendo da autorização), mas que poderia ser interrompida a qualquer momento.

"Iremos, agora, conversar sobre o que você pensou e escreveu. Como já havíamos combinado, esta parte da conversa será gravada, de forma que fique mais fácil, e eu não esqueça alguns detalhes importantes do que você me disser. Caso haja alguma parte que você não queira que eu grave, pode me avisar, que eu interrompo a gravação até que você me autorize continuar gravando. Se você deixar, gostaria de fazer algumas anotações, nos momentos em que não estivermos gravando, essas anotações serão utilizadas somente após sua avaliação e permissão para usá-las”.

Iniciava-se então uma conversa sobre cada ponto levantado pelo entrevistado e, à medida que surgiam dúvidas ou que a ideia não ficava clara, o entrevistador solicitava complementações com o objetivo de elucidar a opinião do entrevistado.

\subsubsection{A realização do trabalho de campo}

O trabalho de campo foi desenvolvido em diversos momentos, tendo início em outubro de 2011, quando o projeto deste estudo, antes de ser encaminhado ao Comitê de Ética 
em Pesquisa da FFCLRP-USP, foi apresentado, avaliado e aprovado em reunião ordinária do Conselho dos Secretários Municipais de Saúde de Uberaba (COSEMS - Uberaba). Estavam presentes 22 gestores de um total de 27 da Macrorregião Triângulo Sul. Após reunião, o Termo de Autorização para Coleta de dados foi assinado pelo presidente do colegiado.

O segundo momento do desenvolvimento do trabalho de campo ocorreu no período de junho de 2012 a outubro de 2013, quando retomamos o contato com os Gestores, via COSEMS. Foi realizada uma breve reapresentação do projeto, destacando os municípios selecionados para participarem do estudo, os procedimentos de seleção dos municípios e sujeitos, bem como os procedimentos para o desenvolvimento das entrevistas em cada município. Todos os gestores dos municípios selecionados estavam presentes e reiteraram o aceite em participar do estudo. Desta forma, foram coletados os contatos dos gestores que participariam do estudo, bem como definidas algumas datas para realização das primeiras entrevistas, que se iniciariam, de acordo com a disponibilidade dos gestores.

A partir deste momento a maior dificuldade do trabalho de campo foi obter horário na complicada agenda de cada um dos Secretários de Saúde, demandando uma série de (re)agendamentos até o término da coleta de dados. Contribuiu para esta dificuldade o atravessamento do trabalho pelo pleito eleitoral das eleições municipais de 2012.

Em virtude das eleições, houve mudança de cinco secretários de saúde do grupo previamente selecionado, sendo que dois já haviam sido entrevistados. Os três novos gestores foram contatados durante reunião do COSEMS no início do ano de 2013, colocados a par do processo da pesquisa em andamento desde 2011 e convidados a participar do estudo. Todos os três aceitaram prontamente o convite.

Apesar das dificuldades com os agendamentos, (re) agendamentos e mudanças de gestores, a receptividade dos informantes em todos os municípios foi muito boa e o pesquisador não encontrou maiores dificuldades para a realização da pesquisa. Todas as entrevistas foram filmadas, com o consentimento dos entrevistados, sendo que apenas um dos sujeitos não permitiu a filmagem, mas consentiu que a entrevista fosse áudio-gravada, opção disponibilizada pelo pesquisador aos sujeitos durante o rapport.

Para a realização das entrevistas nos municípios foi necessário que o pesquisador se hospedasse em cada um deles por dois dias. O contato e as entrevistas eram iniciados sempre pelo Secretário Municipal de Saúde, que posteriormente, a pedido do pesquisador, indicava o Conselheiro Municipal de Saúde mais atuante para ser entrevistado ou como referido por um dos Secretários: “...o mais chato? O mais Cricri?” (S6.MMP). 
Após a indicação, o próprio Secretário auxiliava no contato e convite ao Conselheiro para participar do estudo. Na maioria das vezes disponibilizava-se a sala, na própria Secretaria de Saúde, em que comumente ocorriam as reuniões do Conselho para que a entrevista fosse realizada. No momento do rapport, eram esclarecidos ao conselheiro os objetivos da pesquisa e os procedimentos para a entrevista. Em apenas um município a entrevista ocorreu em sede própria do conselho, uma casa alugada pela Secretaria de Saúde para este fim.

Via de regra, no primeiro dia em cada município, realizava-se a entrevista com o Secretário Municipal de Saúde pela manhã e com o Conselheiro no período da tarde. Os melhores dias para as entrevistas eram quintas e sextas-feiras, dias em que as demandas das secretarias e unidades de saúde eram menores e não concorriam com as reuniões da Comissão Intergestores Regional (CIR), da Comissão Intergestores Regional Ampliada (CIRA) ou do COSEMS, que aconteciam entre segunda e quarta-feira, normalmente no início de cada mês, na cidade de Uberaba.

O segundo dia era reservado para a entrevista com o usuário, o pesquisador procurava o Secretário de Saúde que indicava uma Unidade de Saúde, em que houvesse a possibilidade de se entrevistar um usuário que estivesse aguardando por atendimento ou que já havia recebido o atendimento e apresentasse condições, disponibilidade e interesse em participar do estudo.

Ao chegar à unidade indicada, após apresentações e breve explicação da pesquisa aos funcionários, era solicitado uma sala em que houvesse condições de realizar a entrevista e montagem do equipamento de filmagem. Em todas as unidades a sala oferecida foi um consultório médico que não estava sendo utilizado no momento. Feito isso, abordava-se os usuários na sala de espera, foram poucas as negativas para participar do estudo, pelo contrário, sempre encontrávamos mais de um usuário querendo participar, mas frisávamos que a nossa necessidade era de apenas um sujeito. Nestes casos, em consenso com os usuários interessados definia-se o entrevistado. Era comum, aguardar o usuário ser atendido para depois realizarmos a entrevista, o que sem sombra de dúvidas era mais conveniente ao usuário. No rapport, eram esclarecidas dúvidas sobre a pesquisa e os procedimentos para a entrevista.

Vale ressaltar que os dados foram coletados em uma única entrevista com cada participante. Para a coleta, foram percorridos pelo pesquisador, aproximadamente $3.846 \mathrm{~km}$. Em média as entrevistas duravam cerca de uma hora e dez minutos, com exceção ao grupo dos gestores em que as entrevistas duraram em média duas horas. Tal fato deve-se as inúmeras interrupções que aconteciam durante as entrevistas, ora pela necessidade de assinar 
algum documento, ora para atender ao prefeito, ora para atender aos vereadores, ora para atender ao contador ou secretário de governo e em alguns momentos para atender ao oficial de justiça.

\subsection{Questões éticas para realização do estudo}

Ressaltamos que pelas características do presente estudo, foram observadas todas as normatizações da Comissão Nacional de Ética em Pesquisa - CONEP, presentes na resolução do Conselho Nacional de Saúde (CNS) n 466, de 12 de dezembro de 2012, que revoga, em 13 de junho de 2013, a resolução do CNS nº 196/96 e suas complementares.

O Estudo foi apresentado e aprovado pelo Colegiado dos Secretários Municipais de Saúde (COSEMS - Uberaba), sendo assinado o Termo de Autorização para Coleta de Dados pelo seu presidente (APÊNDICE A).

O projeto de pesquisa deste estudo e os Termos de Consentimento Livre e Esclarecido (ANEXO B e APÊNDICES B e C) foram submetidos e autorizados pelo Comitê de Ética em Pesquisa (CEP) da Faculdade de Filosofia, Ciências e Letras de Ribeirão Preto da Universidade de São Paulo (FFCLRP-USP).

A coleta de dados teve início somente após a aprovação pelo Comitê de Ética em Pesquisa da Faculdade de Filosofia, Ciências e Letras de Ribeirão Preto e pelo Colegiado dos Secretários Municipais de Saúde da Macrorregião de Uberaba, local onde a pesquisa foi realizada. No momento de realização das entrevistas foram esclarecidas individualmente a cada sujeito todas as informações sobre os objetivos e procedimentos da pesquisa, também foi assinado o Termo de Consentimento Livre e Esclarecido, que assegura o anonimato das informações pessoais, a participação voluntária e o compromisso de que as informações fornecidas seriam utilizadas em trabalhos científicos.

\subsection{Análise de conteúdo e tratamento dos dados}

Esta etapa partiu da análise de conteúdo dos depoimentos emitidos pelos participantes nas entrevistas, que foram filmadas ou áudio-gravadas (com filmadora digital) e transcritas integralmente, preservando todas as características dos depoimentos dos participantes. 
Hoje o dilema dos que trabalham com análises qualitativas é de superar os esquemas interpretativos formais (à la Berelson) ou o funcionalismo (à la Malinowski) em busca de uma teoria dialética capaz de conter os conteúdos intrinsecamente conflitivos e antagônicos de nossa realidade social. A Abordagem que mais se coaduna à interpretação consistente dos dados é a marxista, na medida em que ela se propõe a captar o movimento, as contradições e os condicionamentos históricos (Minayo, 1998, p. 230).

De acordo com Minayo (1998), enquanto o materialismo histórico representa o caminho teórico que aponta a dinâmica do real na sociedade, a dialética refere-se ao método de abordagem deste real. Para a autora, a dialética

esforça-se para entender o processo histórico em seu dinamismo, provisoriedade e transformação. Busca apreender a prática social empírica dos indivíduos em sociedade (nos grupos e classes sociais), e realizar a crítica das ideologias, isto é, do imbricamento do sujeito e do objeto, ambos históricos e comprometidos com os interesses e as lutas sócias de seu tempo (p. 65).

A postura interpretativa dialética, busca apreender o movimento dos fenômenos sociais, negando sua imediaticidade, entendendo-os como em um constante movimento. Assim, tudo que existe é tomado como em movimento, nada no mundo está imóvel, tudo está sujeito ao movimento da história humana ou natural (Löwy, 1991; Triviños, 1987). Esse movimento/desenvolvimento de um sistema material é desencadeado e impulsionado por contradições internas, isto é, pelo choque de várias forças e tendências que estão ativas em determinando fenômeno. Ou seja, a contradição, que se apresenta na realidade objetiva, seria a fonte e a força motriz do movimento perpétuo dos fenômenos (Löwy, 1991; Triviños, 1987; Hahn \& Kosing, 1983), sendo o maior exemplo desta, a "luta de classes decorrente da insanável contradição do sistema capitalista: o caráter social da produção versus apropriação privada do resultado do trabalho" (Skalinski \& Praxedes, 2003, p. 306). "A luta de classes é, porém, a mais importante força motriz direta do movimento e desenvolvimento histórico de qualquer sociedade de classes" (Hahn \& Kosing, 1983, p. 68).

Tendo em vista os princípios do movimento perpétuo e das contradições que são próprias de qualquer sistema material, podemos afirmar que existe uma dependência mútua, uma interação entre todos os aspectos das coisas e dos fenômenos, sendo o objeto da dialética o desvelamento dessas interações e de suas contradições internas fundamentais a fim de que se possa compreender a dinâmica dos fenômenos (Löwy, 1991; Skalinski \& Praxedes, 2003; Hahn \& Kosing, 1983). Dentro dessa concepção, nenhum fenômeno pode ser adequadamente compreendido se isolado do contexto em que está inserido ou em simples decomposição de seus elementos constituintes (Löwy, 1991). Destarte, torna-se importante 
situar os dados levantados dentro do quadro histórico a partir do qual foram extraídos. Negligenciando-se esse procedimento, não é possível uma correta apreensão do concreto, pois este seria tomado como uma mera soma de dados parciais. Ao contrário, o que o método dialético busca é produzir sínteses de abstrações, investigando a totalidade concreta da realidade, analisando cada fenômeno social como inserido dentro dessa totalidade. Com isso, busca-se captar os fenômenos como concretudes históricas, e não como fatos em si ou apenas ideias sobre os fatos [itálicos nossos] (Skalinski \& Praxedes, 2003, p. 306).

Portanto, de acordo com Minayo (1998) a epistemologia marxiana toma como centro da análise "a prática social, a ação humana e a considera como resultado de condições anteriores, exteriores, mas também como práxis. Isto é, o ato humano que atravessa o meio social conserva as determinações, mas transforma o mundo sobre as condições dadas” (p. 232).

Disso resulta inclusive, a impossibilidade de juízos neutros na construção do conhecimento e assim sendo, para a epistemologia materialista-histórico-dialética não basta constatar como as coisas funcionam nem estabelecer conexões superficiais entre fenômenos. Trata-se de não se perder de vista o fato histórico fundamental de que vivemos numa sociedade capitalista, produtora de mercadorias, universalizadora do valor de troca, enfim, uma sociedade essencialmente alienada e alienante que precisa ser superada (L. Martins, s.d., p. 16).

Sem dúvidas, a natureza deste trabalho pede uma abordagem dialética marxista, pois entendemos que o objeto deste estudo faz parte de um processo sócio-histórico, em transformação e contraditório, que compõe um todo orgânico e que não pode ser entendido isoladamente. Com esta perspectiva, a prática do Sistema Único de Saúde foi investigada empiricamente e sua análise realizou-se através da crítica das ideologias naturalizadas nas visões dos sujeitos.

A análise qualitativa foi processada com base em procedimentos desenvolvidos por M.A. Figueiredo (1998), que destacam conteúdos temáticos identificados ex post facto (APÊNDICE D) a partir de sínteses fundamentadas em análises sucessivas, realizadas em diferentes etapas descritas abaixo e ilustradas ao final (Figura 7).

Primeira Fase: Realizada sobre as transcrições das entrevistas, nesta fase a junção é feita partindo de conteúdos comuns, dentro de uma mesma entrevista. Compreende as seguintes etapas:

A. Leitura Inicial: é feita uma série de leituras em profundidade, para identificar trechos preliminares, ligados às Categorias Temáticas de conteúdos evocados.

B. Marcação: são selecionados alguns trechos, destacando os conteúdos inscritos nas Categorias Temáticas, além de outros, julgados significantes. 
C. Corte: os trechos destacados são, então, retirados do texto.

D. Notação: observações marginais são feitas sobre cada trecho, localizando-o no contexto das entrevistas e na literatura pertinente

E. Primeira Junção: os trechos são dispostos, por pessoa, em protocolo de análise.

F. Organização: tais observações marginais devem servir como referencial para organização dos dados numa segunda junção, onde serão agrupados os trechos de todos os entrevistados, considerando uma mesma Categoria Temática.

Segunda Fase: feita a partir da Segunda Junção refere se a conteúdos comuns às várias entrevistas, compreendendo etapas similares à primeira fase:

G. Leitura Inicial: compreende uma série de leituras em profundidade, onde são identificados alguns trechos preliminares, agora por Categoria Temática.

H. Organização: tais trechos são agrupados e classificados por subcategorias, ou seja, em conformidade com conteúdos específicos na mesma Categoria Temática.

I. Notação: tomando um protocolo semelhante ao da fase anterior, as notações são ampliadas e relacionadas, entre si, dentro de uma mesma Categoria Temática.

J. Redação Final: baseado na segunda notação é realizado a redação definitiva.

\begin{tabular}{|c|c|}
\hline \multirow{6}{*}{$\begin{array}{c}\text { PRIMEIRA FASE }{ }^{24} \\
\text { (Sujeitos) }\end{array}$} & A. LEITURA INICIAL \\
\hline & B. MARCAÇÃO \\
\hline & C. CORTE \\
\hline & D. PRIMEIRA JUNÇÃO \\
\hline & E. NOTAÇÃO \\
\hline & F. ORGANIZAÇÃO \\
\hline \multicolumn{2}{|c|}{ SEGUNDA JUNÇÃO (PRIMEIRA SÍNTESE) } \\
\hline \multirow{4}{*}{$\begin{array}{l}\text { SEGUNDA FASE }{ }^{25} \\
\text { (Conteúdos) }\end{array}$} & G. LEITURA INICIAL \\
\hline & H. ORGANIZAÇÃO \\
\hline & I. NOTAÇÃO \\
\hline & J. REDAÇÃO FINAL \\
\hline
\end{tabular}

Figura 7. Quadro de etapas dos procedimentos de Análise de Conteúdo do Material transcrito nas entrevistas

\footnotetext{
${ }^{24}$ Conteúdos relacionados a várias Categorias, do mesmo sujeito ou mesmo grupo.

${ }^{25}$ Conteúdos de vários sujeitos ou vários grupos, em uma mesma Categoria.
} 
CAPÍTULO 3 - RESULTADOS E REFLEXÕES 

Nesta seção, além de breve caracterização sociodemográfica dos sujeitos, serão apresentadas e discutidas categorias temáticas identificadas a partir dos depoimentos expressos durante as entrevistas realizadas. Tais categorias apontam os focos de interesse e os posicionamentos dos entrevistados em relação ao enfrentamento do processo saúde/doença, frente uma saúde expressão da triste relação social da hegemonia da mercadoria.

Para melhor organização, analisaremos os resultados obtidos, separadamente, por grupos de sujeitos e na ordem em que foram realizadas as entrevistas em cada município, ou seja, primeiro a percepção dos Secretários Municipais de Saúde, após a dos Conselheiros Municipais de Saúde (sempre representantes dos usuários) e, por último, a percepção dos Usuários.

Os depoimentos que apoiam as análises realizadas foram codificados, garantindo o anonimato dos participantes e permitindo a identificação de subgrupos (dentro de cada grupo) conforme parâmetros populacionais dos municípios de residência dos sujeitos. Nesse sentido, utilizamos para identificar os Secretários Municipais de Saúde a letra S, os Conselheiros a letra $C$ e os Usuários a letra $U$. Para identificação do contingente populacional dos municípios utilizamos, respectivamente, as seguintes combinações: MGP (Município de Grande Porte); MMP (Município de Médio Porte) e MPP (Município de Pequeno Porte).

Ao final da combinação de letras, acrescentamos o número do item que identifica os recortes nos quadros síntese (APÊNDICE D). Desta forma, o código S.MGP-1.1 representa o recorte do depoimento de um Secretário Municipal de Saúde, gestor do SUS em um município de grande porte populacional, sendo este recorte, localizado na posição 1.1 dos quadros síntese e assim sucessivamente para cada grupo de sujeitos.

Sob a perspectiva do materialismo histórico e dialético, a síntese da análise de conteúdos dos depoimentos obtidos via entrevistas, permitiu a identificação ex post facto de três Categorias Temáticas, uma para cada segmento dos entrevistados, sendo elas: Categoria 1 - Racionalidades do Sistema Único de Saúde (Secretários Municipais de Saúde); Categoria 2 - Racionalidades do Controle Social (Conselheiros Municipais de Saúde) e Categoria 3 - Relatos de vidas marcadas pela reificação (Usuários do SUS). Tais categorias, por sua vez, se desdobraram em Unidades Temáticas, dispostas em organogramas, apresentadas e discutidas em itens subsequentes. Vale destacar que apesar de academicamente discutidas em separado, as unidades temáticas de cada categoria são, com certeza, imanentes entre si e foram apresentadas e discutidas a partir de sua emersão nas entrevistas. 
3.1. Perspectivas apontadas por Secretários Municipais de Saúde sobre o Sistema Único de Saúde (SUS)

\subsubsection{Caracterização dos Secretários Municipais de Saúde (Gestores do SUS)}

Na figura a seguir, apresentamos o perfil sociodemográfico do segmento estudado, considerando: idade, sexo, estado civil, formação, pós-graduação, tempo de serviço público, carreira/especialização, tempo como secretário de saúde, população do município e salário. 


\begin{tabular}{|c|c|c|c|c|c|c|c|c|c|c|c|}
\hline \multicolumn{2}{|c|}{ Participantes } & \multirow{2}{*}{$\begin{array}{c}\text { Idade } \\
72\end{array}$} & \multirow{2}{*}{$\begin{array}{c}\text { Sexo } \\
\text { M }\end{array}$} & \multirow{2}{*}{$\begin{array}{c}\begin{array}{c}\text { Estado } \\
\text { Civil }\end{array} \\
\text { Casado }\end{array}$} & \multirow{2}{*}{$\begin{array}{c}\text { Formação } \\
\text { Medicina }\end{array}$} & \multirow{2}{*}{$\begin{array}{c}\text { Pós-Graduação } \\
\begin{array}{c}\text { Pós-Doutorado em } \\
\text { Bioquímica }\end{array}\end{array}$} & \multirow{2}{*}{$\begin{array}{c}\begin{array}{c}\text { Tempo de } \\
\text { Serviço } \\
\text { Público }\end{array} \\
51 \text { anos }\end{array}$} & \multirow{2}{*}{$\begin{array}{c}\begin{array}{c}\text { Funcionário de } \\
\text { carreira? } \\
\text { Especificação }\end{array} \\
\text { Sim. } \\
\text { Docente } \\
\text { Universitário }\end{array}$} & \multirow{2}{*}{$\begin{array}{c}\begin{array}{c}\text { Tempo } \\
\text { como } \\
\text { Secretário }\end{array} \\
\\
4 \text { anos }\end{array}$} & \multirow{2}{*}{$\begin{array}{c}\begin{array}{c}\text { População } \\
\text { do } \\
\text { Município+ }\end{array} \\
295.988 \text { hab. }\end{array}$} & \multirow{2}{*}{$\begin{array}{c}\text { Salário de } \\
\text { Secretário } \\
\text { R } \$ \\
8.000,00\end{array}$} \\
\hline 1 & S.MGP & & & & & & & & & & \\
\hline 2 & S.MGP & 57 & M & Casado & $\begin{array}{l}\text { Engenharia } \\
\text { Mecânica }\end{array}$ & $\begin{array}{c}\text { Esp. em } \\
\text { Administração e em } \\
\text { Ciências Políticas. }\end{array}$ & 27 anos & Não. & $\begin{array}{l}2 \text { anos e } \\
\text { meio }\end{array}$ & 93.672 hab. & $\begin{array}{c}\mathrm{R} \$ \\
7.000,00\end{array}$ \\
\hline 3 & S.MGP & 49 & $\mathrm{~F}$ & Casada & Direito & $\begin{array}{l}\text { Esp. em Direito } \\
\text { Médico e da Saúde }\end{array}$ & 35 anos & $\begin{array}{c}\text { Sim. } \\
\text { Auxiliar de Saúde }\end{array}$ & 08 meses & 53.468 hab. & $\begin{array}{c}\mathrm{R} \$ \\
6.000,00\end{array}$ \\
\hline 4 & S.MMP & 42 & M & Solteiro & Enfermagem & $\begin{array}{l}\text { Esp. em Unidade de } \\
\text { Terapia Intensiva }\end{array}$ & 15 anos & Não. & 4 anos & 23.218 hab. & $\begin{array}{c}\mathrm{R} \$ \\
7.000,00\end{array}$ \\
\hline 5 & S.MMP & 48 & $\mathrm{~F}$ & Casada & $\begin{array}{l}\text { Gestão } \\
\text { Pública }\end{array}$ & $\begin{array}{l}\text { Esp. em Adm. de } \\
\text { Serviços Públicos de } \\
\text { Saúde }\end{array}$ & 27 anos & $\begin{array}{c}\text { Sim. } \\
\text { Téc. de Enfermagem }\end{array}$ & 6 anos & 23.043 hab. & $\begin{array}{c}\mathrm{R} \$ \\
3.500,00\end{array}$ \\
\hline 6 & S.MMP $†$ & 41 & $\mathrm{~F}$ & Casada & Administração & $\begin{array}{l}\text { Esp. em Planejamento } \\
\text { e Gestão }\end{array}$ & 18 anos & $\begin{array}{c}\text { Sim. } \\
\text { Assessor } \\
\text { Administrativo }\end{array}$ & $\begin{array}{l}4 \text { anos e } \\
\text { meio }\end{array}$ & 10.384 hab. & $\begin{array}{c}\mathrm{R} \$ \\
4.000,00\end{array}$ \\
\hline 7 & S.MPP & 37 & $\mathrm{~F}$ & Casada & $\begin{array}{c}\text { Técnico em } \\
\text { Contabilidade }\end{array}$ & Não se aplica & 06 anos & $\begin{array}{c}\text { Sim. } \\
\text { Oficial de } \\
\text { Administração }\end{array}$ & 08 meses & 3.265 hab. & $\begin{array}{c}\mathrm{R} \$ \\
4.000,00\end{array}$ \\
\hline 8 & S.MPP $†$ & 37 & $\mathrm{~F}$ & Casada & Psicologia & Esp. em Acupuntura & 14 anos & $\begin{array}{c}\text { Sim. } \\
\text { Psicóloga }\end{array}$ & $\begin{array}{l}2 \text { anos e } \\
\text { meio }\end{array}$ & 2.972 hab. & $\begin{array}{c}\mathrm{R} \$ \\
3.000,00\end{array}$ \\
\hline 9 & S.MPP & 32 & $\mathrm{~F}$ & $\begin{array}{l}\text { União } \\
\text { Estável }\end{array}$ & $\begin{array}{l}\text { Terceiro grau } \\
\text { incompleto } \\
\text { (Veterinária) }\end{array}$ & Não se aplica & 7 anos & $\begin{array}{c}\text { Sim. } \\
\text { Recepcionista }\end{array}$ & 07 meses & 2.025 hab. & $\begin{array}{c}\mathrm{R} \$ \\
3.600,00\end{array}$ \\
\hline
\end{tabular}

+ IBGE, 2010a; † Ano de referência 2013; Possui Plano Privado de Saúde; † Iniciando, em 2013, segundo mandato à frente da Secretaria Municipal de Saúde.

Figura 8 - Perfil sociodemográfico dos secretários de saúde participantes do estudo 
Observa-se no quadro acima que 44,5\% dos secretários estão entre 40 e 50 anos; $33,3 \%$ entre 30 e 40;11,1\% entre 50 e 60 e outros 11,1\% acima de 60 anos. Em relação à proporção de gênero, foi verificado prevalência do sexo feminino $(66,7 \%)$. Quanto ao estado civil, $77,8 \%$ declararam-se casados; $11,1 \%$ em união estável e $11,1 \%$ solteiro.

No que diz respeito à formação profissional, não houve prevalência de graduação específica, sendo cada um graduado em uma área distinta. Em relação a pós-graduação, prevaleceram as relacionadas à área de Administração/Gestão (44,4\%).

Sete $(77,8 \%)$ dos entrevistados são funcionários de carreira (concursados), com média de tempo de trabalho no Serviço Público de 22,2 anos, mínimo de seis e máximo de 51 . O período como Secretário de Saúde variou entre o mínimo de sete meses ao máximo de seis anos, com média de dois anos e nove meses. Dos nove sujeitos entrevistados, dois $(22,2 \%)$ permaneceram no cargo de Secretário Municipal de Saúde após o pleito eleitoral de 2012.

Considerando a remuneração de Secretário Municipal de Saúde, ano-calendário 2012, os valores variaram entre $\mathrm{R} \$ 3.000,00$ e $\mathrm{R} \$ 8.000,00$, com média bruta (sem descontos) de $\mathrm{R} \$$ 5.122,00 de rendimentos.

Cinco $(55,6 \%)$ dos Secretários participantes do estudo manifestaram ter planos privados de saúde, três por meio de um plano familiar vinculado às empresas onde os cônjuges trabalham e dois por opção, via aquisição direta com as operadoras de planos de saúde. Destes dois, um manifestou utilizar exclusivamente o plano de saúde por acreditar não ser justo que detentores de planos de saúde utilizem o SUS. Os demais declararam utilizar os planos de saúde, o SUS e o sistema de desembolso direto, uma vez que seus convênios cobrem apenas procedimentos básicos, oferecendo descontos mínimos para a maioria dos procedimentos, tendo um deles destacado:

Sabe por que às vezes as pessoas que têm planos de saúde procuram o SUS? Porque o Sistema Público de Saúde às vezes e com frequência resolve muito mais os problemas deles do que os planos de saúde (S.MGP).

Dos quatro sujeitos que não têm plano privado de saúde, um manifestou vontade em adquirir, os outros manifestaram acreditarem no SUS e não acreditarem que os planos privados ofereçam grandes vantagens em relação ao Serviço Público de Saúde, por isso, preferem o SUS e/ou o subsistema de desembolso direto. 


\subsubsection{Categoria 1 - Racionalidades do Sistema Único de Saúde}

"Talvez nossa reflexão deva começar por aí: pelo fato de que nossa sobrevivência está ameaçada"

Sebastião Salgado, Exxodos

Não há dúvidas que estamos diante da "saúde como região institucional do sistema social, especializada em oferecer produtos e serviços para os organismos afetados e afetáveis por processos mórbidos" (Lefèvre, 1991, p. 48).

O que se está tentando neste trabalho é examinar os determinantes sócio-históricos mais gerais ligados à questão da saúde como mercadoria e a função simbólica desta racionalidade, a qual determina o funcionamento do SUS como instrumento do processo de reificação da saúde e da vida.

Nesse sentido, na categoria depreendida dos discursos dos Secretários Municipais Racionalidades do Sistema Único de Saúde - foram reunidos conteúdos referentes aos elementos de enfrentamento para a provisão do direito à saúde (Figura 9), apontando racionalidades e intencionalidades que orientam a atuação dos sujeitos no fazer saúde, bem como para os desafios em garantir um sistema público de saúde universal, democrático e resolutivo, que confronte a racionalidade reificada do atual sistema de saúde.

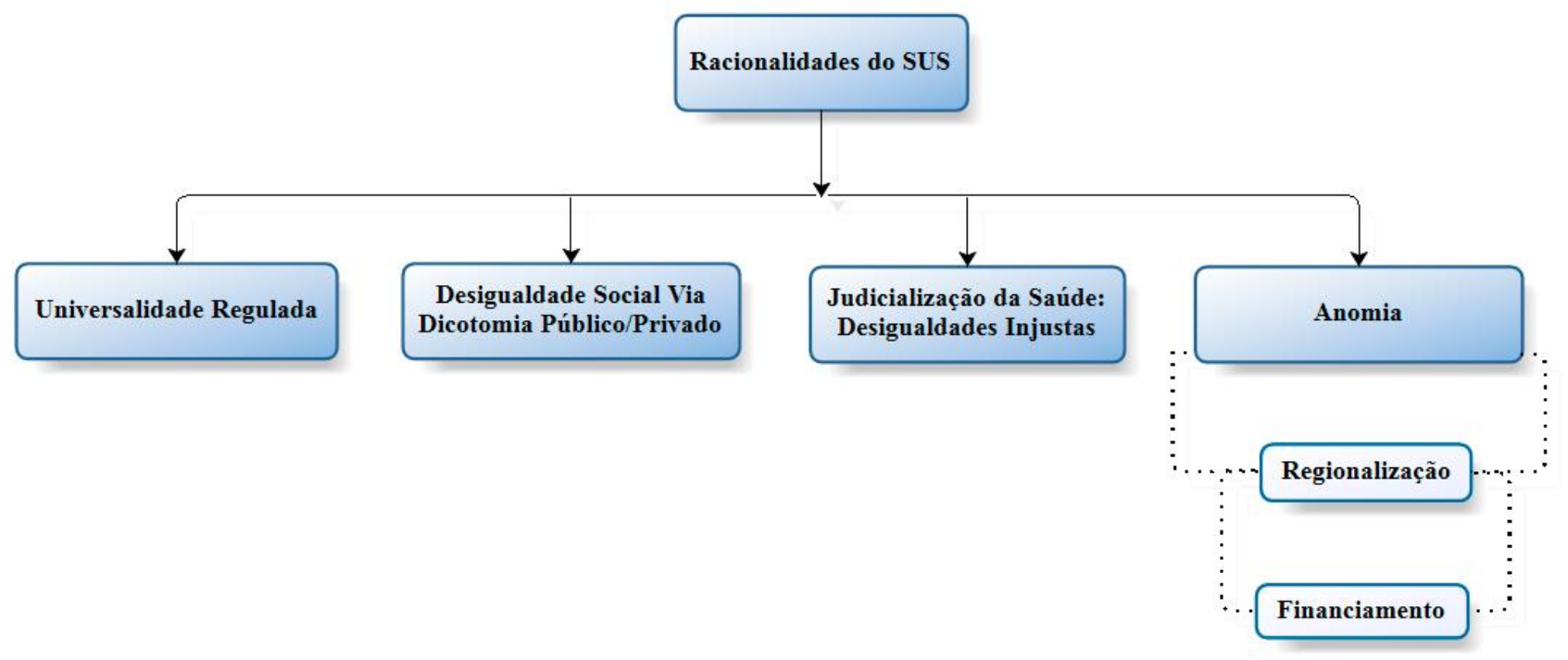

Figura 9 - Organograma demonstrativo das unidades temáticas da categoria 1, Ribeirão Preto, 2015 


\subsubsection{Universalidade Regulada}

O contexto político, social e institucional brasileiro, desde as últimas décadas do século passado, tem sido marcado pelo processo de redefinição do papel do Estado, a partir da universalização dos direitos de cidadania ${ }^{26}$, descentralização e democratização da gestão das políticas públicas (Rocha, 2009). Neste contexto, após a intensa luta social pelo direito à saúde, conhecida como "Movimento Sanitário"27, a Saúde foi, em 1988, consagrada pela primeira vez, na Constituição Federal Brasileira, como direito universal, sendo dever do Estado garanti-lo.

O fato é que o Sistema Único de Saúde brasileiro, tem raízes históricas nas lutas sociais das décadas de 70 e 80, representando no texto constitucional uma importante inflexão no padrão de intervenção do Estado na questão saúde. Antes do SUS, a saúde não era direito de todos e muito menos dever do Estado; estava restrita à parcela da população que contribuía para garantir esse benefício, em uma espécie de seguro social. Assim, um dos primeiros princípios concretizados para garantir o direito à saúde foi a universalização da atenção, passando toda população a ter direito constitucional e incondicional de acesso aos serviços de saúde previdenciários próprios ou contratados (Baptista, 2005; Bertolli Filho, 2002; Finkelman, 2002; Giovanella \& Fleury, 1996; Mendes, 1999; Rocha, 2009; Senna et al., 2010).

Esta breve introdução indica a centralidade que o acesso ao atendimento e recursos do SUS adquire para a análise das políticas públicas de saúde no Brasil. Tal centralidade também foi explicitada nas evocações dos gestores entrevistados no presente estudo, sendo a universalidade do acesso ao sistema público de saúde, apesar das contradições, o aspecto positivo mais importante evocado pela maioria deles, independente do porte populacional do seu município.

\footnotetext{
${ }^{26}$ Buscando os atributos do termo, Janoski (1998 apud L. Vieira, 2001), agrupa perspectivas encontradas em diversos dicionários - legal, normativa e das ciências sociais -, considerando esta última mais apropriada a uma possível reconstrução de uma teoria da cidadania, que seria: "A pertença passiva e ativa de indivíduos em um Estado-nação com certos direitos e obrigações universais em específico nível de igualdade” (p. 36). Nos dizeres de Dalari (1998b): "A cidadania expressa um conjunto de direitos que dá à pessoa a possibilidade de participar ativamente da vida e do governo de seu povo. Quem não tem cidadania está marginalizado ou excluído da vida social e da tomada de decisões, ficando numa posição de inferioridade dentro do grupo social" (p. 14).

${ }^{27}$ Como já citamos anteriormente, o Movimento Sanitário tinha propostas concretas, sendo a primeira delas: a saúde como direito de todos os cidadãos. Independente de classe social ou inserção no mercado de trabalho, não se poderia excluir ou discriminar qualquer cidadão do acesso à assistência pública de saúde.
} 
Eu considero o SUS o melhor plano universal que nós temos. Melhor plano do mundo, considerando o aspecto social! Porém já está na hora de repensarmos o SUS (S.MGP-1.1).

O aspecto mais positivo do SUS é que ele atende a todos (S.MPP-1.2).

O mais importante no SUS é a universalidade, a equidade e a integralidade (S.MGP-1.3).

Dentre os aspectos positivos também tem a universalidade que ao mesmo tempo eu sou contra, foi bom! Mas por outro lado eu sou contra (S.MMP-1.4).

Para Matta (2007, citado por Matta, 2008, p. 467), “a universalidade é o princípio que organiza e dá sentido aos demais princípios e diretrizes do SUS na garantia do direito à saúde de forma integral, equânime, descentralizada e com participação popular” [itálicos nossos].

No entanto, "sabe-se que as normas constitucionais, especialmente aquelas voltadas à garantia de direitos fundamentais sociais ${ }^{28}$ pecam pela (in)efetividade, e que o projeto encartado pelo texto constitucional de um Estado Social não consegue se impor em plenitude" (Rosa \& Marcellino Junior, 2011, p. 48), atropelado pelas políticas neoliberais que se tornaram hegemônicas a partir da década de 90.

Não há dúvidas de que a discussão dos direitos sociais emerge das contradições impostas pelas relações produtivas da sociedade (Telles, 1998). Na saúde brasileira, tais contradições podem ser identificadas dentro do processo de reificação da saúde e seus desdobramentos como: a mercantilização do direito à saúde; denúncias diárias de irregularidades; filas anuais para realização de exames, consultas com especialistas ou procedimentos de média e alta complexidade; falta de estrutura, equipamentos e/ou pessoal; subfinanciamento do sistema; falta de medicamentos; obtenção de privilégios; judicialização do setor; privatizações, terceirizações e quarteirizações de serviços e etc.

Neste contexto, frente às incertezas dos tempos que correm, a falta de perspectivas de melhorias importantes a curto e médio prazo, dada a reificação da saúde e seus desdobramentos, é fator inquietante, não apenas pelo sofrimento humano imediato que representa, mas pela proposição de soluções que signifiquem retrocesso em direitos fundamentais sociais, em níveis já alcançados e garantidos.

\footnotetext{
${ }^{28}$ Para Manzini Covre (2002), os direitos fundamentais sociais "dizem respeito ao atendimento das necessidades humanas básicas, sendo todos aqueles que devem repor a força de trabalho, sustentando o corpo humano alimentação, habitação, saúde, educação etc. Dizem respeito, portanto, ao direito ao trabalho, a um salário decente e, por extensão, ao chamado salário social, relativo ao direito a saúde, educação, habitação, etc.” (p.14). A Constituição Federal de 1988 define e lista os direitos sociais em seu Título II, Dos Direitos e Garantias Fundamentais, Capítulo II, a partir do artigo $6^{\circ}$.
} 
Eu acho que a universalidade deveria ser direcionada, você não tem condições financeiras, tudo bem. Se tem! Você teria que aguardar, não sei se eu estou conseguindo me expressar (S.MMP-1.5).

Há um grande erro na origem, a partir do momento em que se diz: a saúde é direito de todos e dever do Estado, então o bacana que é milionário pode também requerer um atendimento? (S.MGP-1.6).

Pela análise destas locuções podemos observar que, mesmo após vinte e sete anos de criação do SUS, a universalidade de acesso ao atendimento e recursos do Sistema Único de Saúde ainda enfrenta obstáculos para sua efetivação como direito. Apesar de assegurada constitucionalmente, na percepção de parte dos gestores, em especial, dentre aqueles dos municípios de grande e médio porte, a universalidade da saúde oscilou entre o direito incondicional e a condicionalidade do direito, regulada pelo aspecto socioeconômico.

Observar-se que os reflexos da naturalização da forma social da saúde, enquanto mercadoria no capitalismo moderno faz com que os indivíduos deixem de reconhecer o direito à saúde como processo sócio-histórico, passando a reconhecê-lo como elemento reificado de mero negócio.

De acordo com P.L.P. Santos (2013), "Tal fenômeno esconde uma profunda modificação de valores que na prática, denotam enfraquecimento do conceito de cidadania, do próprio modelo de bem-estar e também da Constituição" (p. 2).

Eu acho que deveria haver uma limitação, sei lá! 10 salários mínimos! para tirar esses bacanas do processo (do SUS), isso baseado em quê? No imposto de renda. O bacana que tem grana! "Bicho! aqui não". Eu acho que isso é fundamental para a sobrevivência do SUS (S.MGP-1.7).

Mendes (2001) destaca que não são raras as justificativas de exclusão do SUS de pessoas que podem pagar por serviços ou planos de saúde, por "um suposto, aparentemente, magnânimo: que, ao se instituírem sistemas específicos para quem pode pagar, sobrariam mais recursos públicos para dar uma melhor atenção aos pobres" (p. 59).

A concepção de reserva dos serviços privados para as classes média e alta, liberando recursos públicos para cuidar dos pobres, não é comprovada pela literatura internacional. $\mathrm{Na}$ 
verdade, o que ocorre quando se naturaliza a "universalidade excludente" ${ }^{29}$ do sistema de saúde é, exatamente, o inverso. Assim, ao se criar serviços distintos para os pobres, dada desorganização social e baixa vocalização política desta "clientela", tais serviços tenderão a sofrer com a escassez crônica de recursos e baixa qualidade da assistência (Comisión Económica para América Latina y el Caribe [CEPAL], 2000; Londoño \& Frenk, 1997; Musgrove, 1996).

O modelo de proteção à saúde norte-americano é ilustrativo deste argumento, uma vez constituído por dois programas públicos destinados a clientelas distintas, com níveis de cobertura e sistemas de financiamento diferenciados. Trata-se dos famosos programas Medicaid e Medicare ${ }^{30}$, aprovados em 1965 (Noronha \& Ugá, 1995). Enquanto o primeiro apresenta pior qualidade e menor financiamento por configurar-se como um sistema exclusivo para os pobres, o segundo concebido sob o espirito de um programa geral, garante melhor financiamento e qualidade ao "envolver idosos de diferentes estratos sociais, o que o torna mais suscetível às pressões de grupos sociais mais organizados, especialmente, os segmentos de classe média que dele fazem parte" (Emanuel, 2000, citado por Mendes, 2001, p. 60).

De acordo com Mendes (2001), no Brasil, esse argumento poderia explicar diferenças na eficácia relativa entre programas de saúde pública. Comparando o Programa de controle da AIDS com o Programa de Controle da Hanseníase, o autor destaca que o bom desempenho e resultados satisfatórios do primeiro, certamente, "explicam-se por que a clientela desse programa envolve segmentos de classe média, com alta vocalização política e capazes de conseguir aprovação rápida de uma lei, no Congresso Nacional, que garanta medicamentos e financiamento adequados ao programa” (p. 60). O segundo, dirigido às clientelas quase exclusivamente pobres, historicamente relegadas ao segundo plano, não apresenta o mesmo desempenho, sujeitando inúmeras pessoas à endemia secular, que deveria ter sido erradicada, há muito tempo, no país.

29 Cabe, aqui, esclarecer o conceito de "universalidade excludente". A universalização consagrada na constituição de 1988, consolidava a tendência de políticas redistributivas defendidas pela reforma sanitária, onde se pretendia a inclusão de todos os cidadãos aos benefícios do Sistema Público de Saúde. Porém, a expansão da universalização do sistema de saúde, acompanhada de mecanismos de racionamento, como a queda na qualidade dos serviços, concomitantemente, foi expulsando do subsistema público segmentos sociais de camadas médias e do operariado mais qualificado. Desse modo, o mandamento constitucional é reinterpretado na prática social não como "universalismo inclusivo" - expressão de cidadania plena - mas como um "universalismo excludente", que garante incorporação ao sistema público de segmentos mais carentes e expulsão das camadas mais privilegiadas (Mendes, 1994).

${ }^{30}$ Para mais informações acessar: U.S. Department of Health and Human Services, Centers for Medicare and Medicare Services. Medicare and you 2015. Recuperado em 30 de Janeiro de 2015, de http://www.medicare.gov/Pubs/pdf/10050.pdf 
O sistema segmentado de saúde, naturalizado no discurso de parte dos gestores entrevistados, é caracterizado por segregar diferentes clientelas em nichos institucionais singulares, apresentando, como característica fundamental, a distinção entre pobres e a população com poder aquisitivo para obter planos de saúde, por meio de seus empregadores ou desembolso direto (Londoño \& Frenk, 1997; Mendes, 2001, 2013).

Dentro do SUS, o aspecto mais importante é o atendimento. Principalmente às pessoas de baixa renda, àquelas que realmente no passado nós rotulávamos de indigentes. Para essas pessoas, o SUS veio resolver um problema seríssimo no país, para esse pessoal, eu realmente aceito o SUS como universal (S.MGP-1.8).

De bom! Eu vejo que é um modelo que é exemplo no mundo, que veio contribuir muito pósConstituição Federal de 1988, trouxe um rumo para a saúde no país, principalmente para as pessoas carentes, de menos recursos, menor renda, que não tinham assistência e viviam de favores das Santas Casas, na época nem era INAMPS (S.MGP-1.9).

Eu sou bem mais velha que você, antigamente ou você tinha o INPS ou o Fundo Rural, se você pagasse você consultava. Então eu acho que tinha que ser direcionado. Se você trabalha em uma empresa particular, você contribui com o "INPS", é descontado no salário do meu marido quase $R \$ 500,00$ né? Então? Porque todo mundo não pode pagar de acordo com seu nível econômico? Contribuir de acordo com seu grupo (S.MMP-1.10).

Os Estados Unidos não adotam um sistema público de saúde com cobertura universal. É exemplo emblemático de modelo segmentado, "baseado no seguro-saúde privado", em que os indivíduos são responsáveis por adquirir seu próprio seguro-saúde, com maioria obtendo cobertura por meio de seus empregadores. As exceções são os programas financiados pelo governo e já citados anteriormente, o Medicare e o Medicaid (Noronha \& Ugá, 1995; "Q\&A", 2010; Sanchez \& Ciconelli, 2012).

Estudos e avaliações do sistema segmentado de saúde americano (DeNavas-Walt, Proctor, \& Smith, 2010, 2011; McKinsey Global Institute, 2007, 2008; Noronha \& Ugá, 1995; O’Hara \& Day, 2014; “Q\&A”, 2010; Starr, 1992) têm verificado diversos problemas, dentre os quais podemos destacar: ser um sistema caro e ineficaz, no qual, em 2007, foram investidos cerca de US\$2,2 trilhões em assistência médica, o equivalente a 16,2\% do Produto Interno Bruto (PIB) norte-americano, quase o dobro da média dos outros países da Organização para a Cooperação e Desenvolvimento Econômico (OCDE), sem, contudo, apresentar resultados superiores; sofre o fenômeno da indução da demanda pela oferta, o que aumenta seus custos e a quantidade de procedimentos desnecessários; o acesso é extremamente desigual e depende da pessoa ter um emprego ou condições financeiras; o tipo de cobertura, ou seja, a qualidade do seguro-saúde, varia com o tipo de emprego, não sendo a mesma para um executivo e um trabalhador da construção civil; é o empregador quem escolhe 
o plano de saúde e não o empregado; empregos em tempo parcial e trabalho autônomo não qualificam os indivíduos para o seguro-saúde; esposas e filhos nem sempre estão cobertos ou estão parcialmente protegidos; em casos de separação ou divórcio a perda de cobertura do seguro dos dependentes é um problema frequente; quando alguém sem seguro ou com cobertura inadequada fica doente, é obrigado a pagar suas despesas médicas com recursos próprios; estima-se que metade de todas as falências pessoais nos EUA sejam, pelo menos em parte, resultado de despesas médicas ${ }^{31}$; a perda do emprego significa perda do seguro-saúde, em 2009, 26,1\% dos americanos experimentaram pelo menos um mês sem cobertura de seguro-saúde.

Somando-se a estas questões as tendências modernas de terceirizações e precarização das relações de trabalho, o impacto negativo na assistência à saúde dos sistemas segmentados baseados no seguro-saúde privado vinculados ao emprego será, com certeza, ainda maior (Mendes, 2001).

As dificuldades acima apontadas fizeram com que os problemas do sistema de saúde americano constituíssem, mais uma vez, um dos blocos temáticos centrais das eleições presidenciais norte-americana de 2008 e prioridade doméstica do presidente Barack Obama, culminando, em março de 2010, com a reforma do sistema de saúde, que, de acordo com o presidente, permitirá, em 10 anos, reduzir o déficit federal em 100 bilhões de dólares, ter uma saúde mais acessível e seguradoras mais responsáveis. Tornando obrigatório a todos os americanos comprar um seguro-saúde e ilegal às seguradoras negar cobertura a clientes com doenças pré-existentes (“Q\&A”, 2010; “US healthcare law”, 2011).

Entretanto, apesar de mais uma reforma do sistema de saúde, os censos norteamericanos estimaram que no ano de 2010; 49,9 milhões de pessoas nos Estados Unidos estavam sem seguro-saúde, enquanto em 2009 eram 49 milhões e em 2008; 46,3 milhões (DeNavas-Walt et al., 2010, 2011; “Q\&A”, 2010).

Nesta angulação, as fragilidades do principal modelo segmentado de saúde do mundo, determinadas, principalmente, por ser "baseado no seguro-saúde privado", pela cobertura insuficiente, segregação de clientelas, alto custo e ineficiência na prestação de serviços, que, nas palavras de Navarro (1990, citado por Noronha \& Ugá, 1995, p. 212), "têm raiz no caráter privado e lucrativo da medicina americana", demonstram que este sistema não pode ser

\footnotetext{
${ }^{31}$ A realidade do sistema de saúde norte-americano e o drama vivenciado pela sua população com relação aos serviços de saúde é registrado pelo polêmico diretor americano Michael Moore no filme SICKO de 2007. Disponível em: https://www.youtube.com/watch?v=VoBleMNAwUg
} 
naturalizado como referência de modelo de saúde em contraposição ao SUS, como se pode depreender dos recortes anteriores do discurso de parte dos gestores entrevistados.

A proposta naturalizada de exclusividade do SUS para os pobres e do sistema suplementar de planos privados de saúde para os ricos reproduz a fragmentação da própria sociedade, negligenciando a principal causa das desigualdades, ou seja, a luta de classes. Trata-se de uma reificação, que nega as relações sociais (econômicas, políticas, ideológicas e culturais) e o caráter sócio-histórico de construção do Direito à Saúde, sendo, de acordo com Brito, Miranda, S.I.T. Ferreira, S. Campos e Nunes (2011), funcional a ordem do Estado burguês, na medida que restringe a igualdade apenas ao seu aspecto formal, colocando a perspectiva universalista cada dia mais distante de sua efetivação.

De acordo com Mendes (1994), o discurso neoliberal naturalizado centra, no mandamento constitucional da universalização, a causa principal das dificuldades na área da saúde, sendo expressivo desta posição o enunciado abaixo:

Assim! A universalidade foi boa num certo ponto, mas ela sobrecarregou o SUS, que é novo, tá começando agora. Então! Essa demanda grande, você ficar na fila muito tempo esperando vaga com o especialista, é por isso! Porque deixou ao livre acesso da população. Então, eu acho que deveria ter uma contribuição. Por mais que a gente já pague os impostos, eu acho que deveria (S.MMP-1.11).

Concordamos com Medici e F. Oliveira (1991, citados por Mendes, 1994), quando asseveram:

Este tipo de mensagem, formulada ideologicamente pelos liberais e veiculada amplamente pela mídia de massa, encontra grande receptividade na sociedade, porque, de um lado, tem por detrás de si o fenômeno mais geral da pandemia neoliberal e, de outro, porque vem acompanhada de denúncias sobre o indiscutível "caos da saúde" (p. 101).

Nesse sentido, está aberto o campo para que, mecanicamente, se efetive a receita infalível do neoliberalismo para a saúde, ou seja, a privatização (Mendes, 1994).

Em síntese - "com o suposto, aparente, magnânimo: que, ao se excluírem as pessoas que podem pagar por serviços privados de saúde, sobrariam mais recursos públicos para dar melhor atenção aos pobres" - o que se percebeu das entrevistas com os gestores foi a adoção do comportamento reificante individualista que ocasiona a naturalização de um sistema segmentado de saúde, em que prevalece o estigma do Sistema Único de Saúde exclusivo para as pessoas carentes.

Com base em pressupostos neoliberais, o debate sobre a Universalidade ou Universalidade Regulada dos serviços públicos de saúde desenvolve certas manifestações, 
aparentemente, favoráveis a um sistema de saúde mais justo e de "cobertura universal" (Organização Mundial da Saúde [OMS], 2010a, 2013). Entretanto tais manifestações, como o canto da sereia, seduzem-nos e nos chamam irreflexivamente para as profundezas da mercantilização da saúde.

Por trás da proposta de "cobertura universal de saúde" ou "novo universalismo", defendida pela Fundação Rockefeller e pelo Banco Mundial e que se tornou central no planejamento das políticas internacionais da Organização Mundial da Saúde (OMS, 2010a, 2010b, 2013), supostamente favorável ao direito de todos e aos serviços públicos de saúde, "esconde-se a forma mais insidiosa de defesa dos interesses privados que enxergam a saúde como mero negócio" (Diretoria Nacional do Cebes, 2014, p. 194).

A fórmula da 'cobertura universal de saúde' aparece de forma mais crua no documento publicado pela Fundação Rockefeller 'Mercados futuros de saúde: uma declaração da reunião em Bellagio'. Esse documento resultou de encontro promovido pela Fundação, em 2012, defendendo abertamente que uma parcela crescente da população de diversos países está disposta a pagar por serviços de saúde e que poderosos atores do mercado se propõem a investir para que países de renda média e baixa adotem sistemas de saúde baseados na lógica do seguro (Diretoria Nacional do Cebes, 2014, p. 195).

Esta proposta segmenta a população de acordo com seu poder aquisitivo, ficando a cargo do Estado apenas a responsabilidade pela saúde dos mais vulneráveis, o que fortaleceria a desigualdade social dentro das sociedades (A. Antunes \& Mathia, 2014). Para Noronha (2013), a "cobertura universal de saúde" é a formula para misturar conceitos, confundir objetivos e abandonar princípios.

Com estas apreciações, nossa convicção e de que se faz premente a necessidade de reforçar iniciativas democratizantes e universalizantes do direito à saúde, em uma abordagem dialética da vida cotidiana ${ }^{32}$, viabilizando processos de desconstrução crítica das armadilhas do caráter privativo e lucrativo da saúde reificada que se apresenta, na atualidade, hegemonicamente como mercadoria.

32 Para R.L.C. Antunes (2009), "é central a recorrência ao universo da vida cotidiana, quando se quer transcender do âmbito e da ações próprias da consciência espontânea, contingente, mais próximas da imediatidade, para as formas de consciência mais dotadas de valores emancipados, livres e universais" (p. 166). 


\subsubsection{Desigualdade Social via Dicotomia Público/Privado}

"O difícil não é evitar a morte, mas evitar que ela seja injusta"

Sócrates

Estamos em um processo avançado de desestruturação do SUS como possibilidade, uma vez que ele nunca se consolidou, reflexo da ideologia neoliberal hegemônica e da naturalização da saúde como mercadoria.

Como já citamos anteriormente, apesar do arcabouço jurídico-constitucional, não se pode falar em um Sistema Único e articulado de Serviços de Saúde. É mais apropriado falar em três subsistemas de saúde: o subsistema público (representado pelo SUS), o Subsistema de Atenção Médica Supletiva e o Subsistema de Desembolso Direto (os dois últimos, sistemas privados) que, lado a lado e de maneira concorrente, tentam atender às demandas e necessidades de saúde da população brasileira (Mendes, 1999, 2001, 2013).

Em seus 27 anos de existência, o SUS vem enfrentando uma disputa desigual contra o sistema privado de saúde, o qual conta, historicamente, com subsídios fiscais; compras de serviços pelo Estado, proporcionando-lhe manutenção de um mercado cativo e amplo apoio social, viabilizado por um "poderoso marketing veiculado pela mídia, apontando com insistência 'insatisfatória qualidade dos serviços públicos' e alardeando enfaticamente a 'eficiência dos planos privados de saúde', que captam clientes advindos do processo de 'universalização excludente”' (G.R. Silva, 1995, p. 16).

São inúmeros os problemas advindos da dicotomia público/privado, o setor privado vê na saúde reificada um negócio a ser explorado, seja na prestação de serviços, seja por meio da venda de mercadorias propiciadoras de saúde como medicamentos, planos de saúde, procedimentos, exames, etc. Nesse sentido, o setor privado não só concorre, mas invade a esfera pública, produzindo e reproduzindo iniquidades, pelos diferenciais que os três subsistemas apresentam em relação ao acesso quantitativo e qualitativo aos serviços de saúde.

Quantas pessoas têm plano de saúde e deixam de usar seu plano de saúde para usar o SUS? É justo? É o problema da universalidade! Como o SUS é universal essas pessoas se sentem no direito de usar o SUS (S.MGP-1.12). 
Estão tentando desestruturar o SUS e deixar o plano de saúde entrar. Isso seria um contrassenso. Eu vejo pela UNIMED, não sei se esse é um problema geral, mas a UNIMED aqui não vive sem o SUS, ela suga o SUS. Vou te dar um exemplo que eu sei de perto aqui, a UNIMED funciona bem por quê? Porque o município paga o plantonista na Santa Casa e esse mesmo plantonista atende a UNIMED. Se o município não pagar o plantonista, não tem atendimento de UNIMED na Santa Casa. O cara (o médico) não vai lá pra receber só o valor que o convênio paga (S.MGP-1.13).

O sujeito começa a fazer um tratamento particular por um plano de saúde, um tratamento de hemodiálise, de câncer, por exemplo! O plano não dá suporte, aí o sujeito já vem pro SUS. Então se o sujeito fez todo o tratamento particular! Por que ele não paga uma taxa? Por que na hora do alto custo, da alta complexidade, ele corre para o SUS? Não! Então o sujeito teria que contribuir com isso, porque aí você vai passar na frente de pessoas que estão aguardando há muito tempo, você teria um jeito de burlar o sistema (S.MMP-1.14).

Na percepção dos informantes, não há um efetivo atendimento de toda a população como preconizado pela constituição. Há, na verdade, uma estratégia que vincula saúde à lógica do mercado e do trabalho formal. Nesse sentido, calha uma expressiva participação do sistema privado de saúde, especialmente, o contratado por empresas que fornecem planos de saúde aos seus empregados e dependentes, viabilizando "acesso privilegiado" ao Sistema Único de Saúde para uma expressiva parcela da população, de certa maneira, já "privilegiada".

O pessoal usa o plano de saúde como acesso para burlar a fila do SUS. Pois os que têm planos, tem uma condição educacional melhor, até de brigar por seus direitos (S.MMP-1.15).

Acho que quem tem plano de saúde não podia ter SUS (S.MGP-1.16).

Meu município fica a vinte minutos de Frutal e a meia hora de Barretos. A minha região é circunvizinha por usinas, todo mundo tem algum tipo de plano de saúde. Então, vai nos médicos dos planos que as usinas oferecem e querem a medicação pelo SUS. Eu estou tendo esse problema. Por quê? Porque a população vai na rede privada e quer o medicamento do SUS (S.MMP-1.17).

São muitos os olhares sobre o problema, corroborando com o manifestado pelos gestores temos os estudos de Cordeiro, Conill, I.S. Santos e Bressan (2010), Fleury (2009), Gerschman e M.A.B. Santos (2006), Ibanhes et al. (2007) e Mendes (2001), o qual vai um pouco além e assevera: a iniquidade aumenta pela sobreposição unilateral de demanda entre os três subsistemas. Como consequência, os pobres só têm direito ao SUS, enquanto os usuários dos planos de saúde e dos serviços de desembolso direto podem, constitucionalmente, utilizar, também, o sistema público. O autor explica que isto ocorre porque a classe média e os ricos, mais informados e com conhecimentos e relacionamentos pessoais com profissionais, atuam como "caroneiros", tirando proveito das vantagens que o 
sistema público oferece, cobrindo riscos catastróficos, beneficiando-se de exames mais sofisticados, medicamentos e procedimentos de alto custo.

Outra coisa que eu acho que interfere muito no sistema é que o sistema como ele é único, ele é universal! Então ele tem que ter parceria público-privada, não tem jeito, tem que falar a mesma língua. Esse negócio de você ter a condição de fazer a "consultinha" de $R \$ 180,00 \mathrm{em}$ um médico privado e depois descarregar todos os exames que esse médico pediu dentro do SUS tá errado. Tem que rever isso, de alguma forma ou outra, não sei como, mas tem que rever isso. Tem se criar um fluxo adequado (S.MMP -1.18).

O atendimento é assim: a gente vai no consultório particular deles (dos médicos da cidade) $e$ se eu tiver que realizar algum exame aí eu vou ao hospital municipal, tiro RX, faço os exames laboratoriais e se tiver que internar, já interna pelo SUS ou se a pessoa tiver plano e quiser internar pelo particular já interna também (S.MMP-1.19).

Isso é fato. E agora? Quem paga a conta? O plano de saúde recebe a mensalidade dele e ele (usuário) utiliza o SUS. Existe uma lei ai! Que eu acho que é fajuta, me desculpa! Mas é fajuta! Uma lei que diz que o plano de saúde é obrigado a restituir o dinheiro para o SUS. Vai restituir quando? (S.MGP-1.20)

Entretanto, alguns aspectos importantes deste processo devem ser aqui levantados. Primeiro, em sua maioria, os planos de saúde empresariais contratados, bem como alguns individuais, cobrem serviços limitados que não atendem todos os níveis de atenção e necessidades de seus beneficiários. Assim, os beneficiários/usuários, para garantirem seu direito à saúde em prazo razoável, necessitam recorrer aos planos privados para conseguir a consulta com o profissional médico e aos serviços públicos para realizarem procedimentos e tratamentos não cobertos por seus planos e pelos quais não podem pagar.

Pesquisa da Associação Paulista de Medicina (APM), em parceria com o Instituto Datafolha, divulgada em outubro de 2013, revelou que 30\% dos clientes de planos de saúde recorreram ao SUS ou ao atendimento particular para receberem assistência adequada. O levantamento revelou ainda, que em relação à 2012, houve um incremento de $50 \%$ nesta procura (Associação Paulista de Medicina [APM], 2013).

A esse respeito A.M. Costa, Bahia e Scheffer (2013) alertam:

A cobertura privada suplementar jamais será uniforme e continuada, pois há diferenças abissais entre os produtos vendidos; a pessoa sai do emprego que garantia o plano; há exclusão pecuniária (idosos e doentes são expulsos porque gastam muito com saúde); há rescisão de contratos que não interessam mais às operadoras; e a agência reguladora, capturada pelo mercado que deveria controlar, faz vistas grossas ao crescimento dos planos de baixo preço (com rede restrita de prestadores) e planos "falsos coletivos" (contratados por pessoa jurídica, a partir de duas pessoas, e que escapam da regulamentação e ofertam serviços ruins). 
Em segundo lugar, o que pode estar acontecendo é que muitos "pacientes", cansados de esperar pelo atendimento na rede pública de saúde e mesmo nas seguradoras, optam pela consulta particular, utilizando-se de suas economias ou "ganhando" uma consulta por meio de “doação" de políticos ou empresários locais, garantindo, acesso mais rápido ao Sistema Único de Saúde do que pelas vias "normais". Da mesma maneira que na primeira situação, ter realizado a consulta em um médico particular não é garantia de que o usuário tenha condições financeiras para pagar pelos exames e medicamentos necessários, o que os levam a recorrerem ao SUS para efetivarem a continuidade de seus tratamentos.

Interessante registrar que apesar das críticas, quatro, dos cinco gestores que possuem planos de saúde relataram utilizar esta estratégia, ou seja, recorrem primeiramente aos planos de saúde e/ou ao sistema de desembolso direto e, de maneira complementar, especialmente para procedimentos e tratamentos mais complexos, ao SUS.

Eu utilizo os dois sistemas, o SUS: uso nas vacinas, uso nas urgências e emergências, numa cirurgia de alto valor né? Então aquele que diz que não usa o SUS está mentindo né? (S.MGP-1.21)

Independente das críticas ou justificativas dos caminhos ou descaminhos para o acesso e/ou garantia do direito à saúde, neste ponto, o que interessa reter das falas dos gestores distanciando-me das questões reificadas da Administração ou Gestão de Recursos do SUS, bem como da "visão 'economicista' e redutoramente quantitativa da realidade social” (J. Souza, 2009, p. 16) - é a legitimação do estigma de um SUS pobre para os pobres e complementar ao setor privado, sobretudo para os medicamentos e procedimentos de alto custo.

Para Parker \& Aggleton (2001), o estigma desempenha papel central na produção e reprodução das relações de poder e controle em todos os sistemas sociais, fazendo com que alguns grupos sejam desvalorizados e outros privilegiados. Em síntese, está se falando de desigualdade social.

A desigualdade social brasileira pertence ao núcleo da denominada "violência simbólica", que é aquele tipo de violência que não se apresenta como violência e que torna possível a naturalização de uma desigualdade social abissal como a brasileira (J. Souza, 2009).

O conceito de violência simbólica tem muito em comum com o conceito de hegemonia em Gramsci, que se obtém através de uma interação complexa entre forças políticas, sociais e culturais, organizando significados e valores dominantes no campo social 
para legitimar as estruturas da desigualdade, como algo que opera não penas sobre a estrutura econômica e a organização política da sociedade, mas também sobre o modo de pensar, sobre as orientações ideológicas e sobre o modo de conhecer. É o que Gramsci designa como "visão de mundo" (Chaui, 2000a; Gruppi, 1978).

Para J. Souza (2009), “como toda visão superficial e conservadora do mundo, a hegemonia do economicismo serve ao encobrimento dos conflitos sociais mais profundos e fundamentais da sociedade brasileira: a sua nunca percebida e menos ainda discutida 'divisão de classes"” (p. 18).

De acordo com J.A.F. Santos (2011, p. 27), "as divisões de classe social e seus efeitos nas chances de vida decorrem da distribuição desigual de poderes e direitos sobre os recursos produtivos relevantes de uma sociedade. A condição de classe é gerada por relações sociais assimétricas com os recursos ou ativos geradores de vantagens e desvantagens materiais" [itálicos nossos] (p. 27). Nesse sentido, "classe social representa justamente um condicionamento abrangente ou 'status predominante' que vincula os indivíduos à distribuição dos recursos econômicos e sociais e afeta suas oportunidades de saúde" (p. 36).

Em estudo realizado a partir dos dados da Pesquisa Nacional por Amostra de Domicílios - Pnad (IBGE, 2010b), relativo ao período de 1998 à 2008, Viacava (2010), analisa as desigualdades geográficas e sociais no acesso e uso dos serviços de saúde brasileiro e destaca que "as necessidades de saúde distribuem-se desigualmente entre os indivíduos das distintas classes de rendimento familiar mensal, sendo maiores nas classes de menor rendimento" (p. 13). O estudo demonstra que o percentual de pessoas que avaliam seu estado de saúde como ruim ou muito ruim é quase duas vezes maior entre as pessoas mais pobres que entre as mais ricas; para as pessoas de 50 anos ou mais, essa relação é três vezes maior; o autor destaca ainda que a magnitude das desigualdades não melhorou para a população total no período de 1998 a 2008.

A desigualdade em saúde também pode ser avaliada na Pnad pelo percentual de pessoas que referem alguma doença crônica, diagnosticada por médico ou outro profissional de saúde. No caso do diabetes e da hipertensão, o percentual de pessoas com mais de 20 anos que informaram ter recebido o diagnóstico dessas doenças por um profissional, foi sempre maior entre as pessoas de maior renda (Viacava, 2010). Vale destacar que este grupo além de acesso aos planos de saúde, também pode "consumir" serviços pelo SUS e pelo sistema de desembolso direto. 
Para Viacava (2010), outras análises da Pnad demostram que "as chances de doença crônica são sempre maiores nas pessoas com menor escolaridade, quando se controla o efeito de sexo e idade" (p. 14). Neste caso, importante lembrar que não é tanto a educação formal em si que favorece a saúde, mas o acesso que ela proporciona aos melhores empregos, maior renda, planos de saúde, etc.

De acordo com o Pnad (IBGE, 2010b), em 2008, 25,9\% da população brasileira, ou seja, 49,2 milhões de pessoas dispunham de pelo menos um plano privado de saúde. Dentre estas, $77,5 \%$ estavam vinculadas a planos de empresas privadas e $22,5 \%$ a planos de assistência ao servidor público. A cobertura por plano de saúde privado estava positivamente relacionada ao rendimento mensal domiciliar per capita, para as pessoas em domicílios com rendimento per capita de até $1 / 4$ do salário mínimo, apenas 2,3\% tinham plano de saúde, enquanto $82,5 \%$ dos que tinham rendimento de mais de 5 salários mínimos tinham plano de saúde. Considerando apenas os titulares dos planos de saúde privados, observou-se que 20,5\% deles tinham seus planos de saúde pagos integralmente pelo empregador, 43,2\% o pagavam através do trabalho atual ou do trabalho anterior, 28,1\% o pagavam diretamente à empresa do plano de saúde e $8,2 \%$ tinham seus planos pagos por outro morador do domicílio ou não morador do domicílio.

Em 2013, mais de 49 milhões de brasileiros tinham seguros privados de saúde e o gasto privado em saúde equivalia a $53 \%$ de todo o gasto do país com saúde. O setor faturou em 2012, segundo o site da Agência Nacional de Saúde Suplementar (ANS), R\$ 95.417 bilhões, 12,7\% mais do que em 2011 ( $\mathrm{R} \$ 84.657$ bilhões). Para se ter um termo de comparação com o gasto público, as despesas do Ministério da Saúde em 2011 foram de R 62.621 bilhões, $\mathrm{R} \$$ 22.036 bilhões a menos. Trata-se de um setor com forte poder econômico e financeiro, que gasta bilhões de reais ao ano em publicidade, o que certamente contribui para o resultado de pesquisa recente, que mostrou que $90 \%$ dos brasileiros queriam planos privados de saúde, colocando esse 'benefício' em primeiro lugar na lista de desejos da população (Diretoria Nacional do Cebes, 2014, p. 195).

"Os planos e seguros de saúde apropriaram-se das inseguranças societárias da classe média, que se sente ameaçada de cair na "vala comum da pobreza e abandono" (Barbosa, 1992, p. 9 citado por Sarreta, 2009, p. 99).

Eu não tinha plano de saúde, porque até então eu acreditava na política do SUS. Até no início, a gente queria uma emergência, a gente conseguia, a gente conseguia vaga, o máximo que acontecia era a maca da ambulância ficar presa lá no Hospital Escola, que é a história da maca! Mas você conseguia entrar no hospital. Hoje! Você tá lá na porta, eles chamam a 
polícia para você, se falaram para você não $\mathrm{ir}^{33}$. Eu vendo essa situação falei: "Gente! Se eu tiver uma emergência, alguma coisa, eu vou estar passando por isso?” Ai eu fiz o plano de saúde para mim, de medo de acontecer comigo o que eu vejo acontecendo com os meus pacientes (S.MPP-1.22).

Prevalece, neste contexto de salve-se quem puder, o discurso de crise na saúde, em que a ausência de recursos humanos e materiais, (sub)financiamento, falta de leitos, carência de medicamentos, longas filas, etc., representam alvos das investidas neoliberais em demonstrar a "(in)efetividade" do Sistema Único de Saúde e a suposta "eficiência" dos planos privados.

Adota-se o comportamento reificante individualista que determina a extinção da consciência do engajamento, impulsionada pelo esquecimento do pertencimento de classe e, portanto, da gênese do ser social. Em síntese, estamos falando do conceito de reificação em Lukács (1974).

O 'esquecimento' do social no individual é o que permite a celebração do mérito individual, que em última análise justifica e legitima todo tipo de privilégio em condições modernas. É esse mesmo 'esquecimento', por outro lado, que permite atribuir 'culpa' individual àqueles 'azarados' que nasceram em famílias erradas, as quais só reproduzem, em sua imensa maioria, a própria precariedade. Como, no entanto, o social, também nesse caso, é desvinculado do individual, o indivíduo fracassado não é discriminado e humilhado cotidianamente como mero 'azarado', mas como alguém que, por preguiça, inépcia ou maldade, por 'culpa', portanto, 'escolheu' o fracasso (J. Souza, 2009, pp. 43-44).

Na medida em que, como vimos, há uma naturalização da saúde como mercadoria e uma responsabilização dos sujeitos (individual e coletivos) pelo enfrentamento do processo saúde/doença, podemos afirmar que a função social saúde, ao sair paulatinamente da responsabilidade do Estado e da ética do direito universal e passar para a responsabilidade da imediaticidade cotidiana reificada e individual dos sujeitos na esfera da vida social, oculta a luta de classes, ou seja, a divisão entre privilegiados e desprivilegiados.

Como assevera Montaño (2010, p. 260),

\footnotetext{
${ }^{33}$ O Sistema Estadual de Regulação Assistencial em Minas Gerais, mais conhecido como SUSfácil, funciona da seguinte forma: Os hospitais ou Unidades de Pronto Atendimento solicitantes, enviam, através de um sistema informatizado, os laudos dos pacientes com informações de diagnóstico e evoluções clínicas. A partir desses dados, os médicos reguladores avaliam cada caso e fazem a busca pelo leito hospitalar mais adequado para cada paciente, visando sempre a unidade mais próxima, com melhor capacidade técnica e profissional para o atendimento especificado. Enquanto a Central de Regulação de leitos não autorizar e direcionar a transferência do usuário, o mesmo não pode ser encaminhado a nenhum hospital de maior densidade tecnológica, devendo permanecer no hospital ou unidade de origem até que uma vaga seja disponibilizada. Em tese nenhum usuário conseguirá dar entrada em outro hospital sem autorização da Central de Regulação de Leitos.
} 
o projeto neoliberal quer uma sociedade civil dócil, sem confronto, cuja cotidianidade, alienada, reificada, seja a da 'preocupação' e 'ocupação' (não a do trabalho e lutas sociais) em atividades criadoras nem transformadoras, mas voltadas para as (auto-) respostas imediatas às necessidades localizadas.

Entretanto, Minayo (1998) destaca que a saúde só pode ser entendida dentro de uma sociologia de classe, ou seja:

A saúde enquanto questão humana e existencial é uma problemática compartilhada indistintamente por todos os segmentos sociais. Porém as condições de vida e de trabalho qualificam de forma diferenciada a maneira pela qual as classes e seus segmentos pensam, sentem e agem a respeito dela. Isso implica que, para todos os grupos, ainda que de forma específica e peculiar, a saúde e a doença envolvem uma complexa interação entre os aspectos físicos, psicológicos, sociais e ambientais da condição humana e de atribuição de significados. Pois saúde e doença exprimem agora e sempre uma relação que perpassa o corpo individual e social, confrontando com as turbulências do ser humano enquanto ser total. Portanto, incluindo os dados operacionalizáveis e junto com o conhecimento técnico, qualquer ação de tratamento, de prevenção ou de planejamento deveria estar atenta aos valores, atitude e crenças dos grupos a quem a ação se dirige (pp. 15-16).

De acordo com R.L.C. Antunes (2009), “a vida cotidiana não se mostra, então, como o espaço por excelência da vida alienada, mas, ao contrário, como um campo de disputa entre a alienação e a desalienação" (p. 159). O cuidado realizado pela equipe da ESF rural de Sacramento, no período de 2003 a 2005, fornece exemplo desse embate, com uma configuração pouco comum no trabalho em saúde, tomando por base a participação da comunidade, inclui a lógica da determinação sócio-histórica no processo saúde/doença, viabilizando no cotidiano das famílias e comunidade o enfrentamento conjunto da atitude reificada de submissão e dependência, que individualiza e naturaliza os agravos à saúde (E.M. Oliveira, 2009; E.M. Oliveira et al., 2015).

Nessa perspectiva, consideramos o cotidiano como espaço de interação social, arena de lutas, espaço de negociação, onde é possível perceber e enfrentar as contradições e os conflitos que se escondem por debaixo da dicotomia público/privado e hegemonia neoliberal. A forma como essa dicotomia vai se resolver, vai depender das lutas sociais de grupos e classes para fazerem a balança pender, pelo menos assim espero, para a defesa e ampliação dos direitos e conquistas sociais e trabalhistas. 


\subsubsection{Judicialização da Saúde: "Desigualdade injusta”}

"A lei não é pacificação, pois, sob a lei, a guerra continua a fazer estragos no interior de todos os mecanismos de poder, mesmo os mais regulares"

Foucault, Em defesa da Sociedade

Em um contexto de hegemonia neoliberal e naturalização da saúde como mercadoria, o que se observa, em termos de garantia do Direito Universal à Saúde, é a negação de todos os princípios do SUS. Universalidade, integralidade, equidade, regionalização/hierarquização, complementariedade do setor privado e controle social, tornam-se, nos termos de Barbalet (1989, citado por Brito et al., 2011, p. 2), "basicamente políticos e apologéticos" ou, sob a perspectiva marxista, um fetiche.

Nesse contexto, a população cansada do fetiche do acesso como princípio e como direito, que não ultrapassa o universo da retórica, tem se valido do poder judiciário como forma de exigibilidade da garantia do direito de acesso aos serviços e recursos do Sistema Único de saúde.

Não há dúvidas que a Judicialização da Saúde foi o tema que mais afligiu os gestores, tamanha insegurança e vulnerabilidade que proporciona aos mesmos, vez que, como destaca Fleury (2012), são os gestores os “potenciais réus de toda falha do sistema” (p. 161).

Secretaria de saúde hoje no Brasil é um encargo pesado. É uma missão, em determinados aspectos, impossível, principalmente no que tange a nossa relação com o Ministério Público e com o Judiciário (S.MGP-1.23).

De acordo com Barroso (s.d.), o judiciário tem sido provocado a coagir a administração pública a cumprir o que a Constituição lhe determina, garantindo, assim, o direito à saúde dos usuários que solicitam a intervenção.

Para os Secretários Municipais a judicialização da saúde nega os princípios do SUS e, com base em "certo padrão de má-fé" (tanto por parte do judiciário quanto dos usuários que solicitam a intervenção), fura filas de espera e fortalece os interesses privados de profissionais liberais (especialmente médicos), indústria farmacêutica, laboratórios, etc., 
dificultando/inviabilizando a gestão, o acesso, a integralidade e principalmente a equidade dentro do Sistema Único de Saúde.

Na verdade, a judicialização simplesmente é.... E isso eu falei para a promotora! A judicialização na verdade nada mais é do que o fura fila, não tem discussão! O Ministério Público não está fazendo o papel dele, tá furando a fila do sistema que é nacional, que existe uma lei, uma ordem.... E cada vez mais o usuário está aprendendo a furar essa fila, então ele paga a consulta do cardiologista, a consulta do outro especialista, então ele vai para o promotor, então não tem jeito, eu tenho uma fila de espera, se você for judicializar a secretaria, tem que lembrar que tem gente que está a seis meses esperando lá! E o cara que está a um mês vai passar na frente? (S.MMP-1.24)

Eu não tinha controle se os pedidos vinham do particular ou do SUS, mas nós sabíamos, por exemplo, e isso é uma questão muito séria, que alguns medicamentos ou pedidos que eram feitos, não tinham nem o aval científico. Mas o advogado entra, por quê? Porque o médico, infelizmente, lê um trabalho científico que fala que já existia tal produto nos EUA, que estava sendo testado e ele queria testar aqui também. E atrás disso existe outras coisas muito perigosas para serem avaliadas. Por exemplo, porque certos medicamentos, de um determinado laboratório, são sempre pedidos por determinados médicos? Precisa ser questionado isso também? Você tem laboratórios que oferecem aos médicos salários extras, viagens, todos os custos de congressos, etc. E o SUS é obrigado a cobrir? (S.MGP-1.25)

Os médicos prescrevem o medicamento que está mais atualizado, que está mais na moda, mas que não entrou ainda no sistema público de saúde e manda o cara procurar a Secretaria de Saúde. Primeiro, o usuário não acha o medicamento na farmácia básica, procura o secretário, o secretário fala que não tem condições de adquirir, ele vai ao Ministério Público e o Ministério Público entra com uma ação contra mim. Então! Furou totalmente o Sistema, judicializou-se todo o Sistema (S.MMP-1.26).

Muitos são os estudos (Campos Neto et al., 2012; Chieffi \& Barata, 2010; M.A.A. Machado et al., 2011) que apontam para esta estratégia, ou seja, utilização da via judicial, por meio da associação de diversos atores - médicos, advogados, laboratórios, etc., com vistas a garantir o consumo pelo SUS de produtos médico-hospitalares sem considerar os altos custos, critérios de efetividade ou reais benefícios aos usuários, determinando o papel do Estado como principal consumidor da indústria farmacêutica.

Em estudo realizado no Rio de Janeiro, Messeder, Osorio-de-Castro e Luiza (2005) observaram que $36,8 \%$ dos autores de ações judiciais para acesso a medicamentos eram oriundos de hospitais universitários; $19,5 \%$ de clínicas conveniadas ao SUS; $11,1 \%$ de hospitais federais; $10,5 \%$ de postos de atendimento das Secretarias Municipais de Saúde; 10,5\% de médicos particulares; 5,4\% de clínicas não conveniadas ao SUS; 3,6\% de hospitais municipais; $1,3 \%$ de hospitais estaduais e 1,3\% sem informação sobre a origem do prescritor.

Não há dúvidas que esses hospitais são unidades que costumeiramente avaliam novas tecnologias, resultando, desse modo, em unidades prescritoras de fármacos ou de tratamentos inovadores. No entanto, no momento em que os hospitais universitários prescrevem 
medicamentos ou procedimentos ainda não padronizados pelo Sistema Único de Saúde e não os fornecem, geram, de facto, uma demanda não atendida. Situação que predispõe o uso dos mandados judiciais como recurso ao acesso (Messeder et al., 2005).

Em nosso estudo, tal situação pode ser exemplificada pela indicação dos stents farmacológicos $^{34}$ pelos especialistas da área de cardiologia e hemodinâmica do Hospital de Clínicas da Universidade Federal do Triângulo Mineiro (HC/UFTM). O Stent farmacológico é um dispositivo semelhante a uma mola, indicado para pacientes diabéticos com risco de reestenose (estreitamento) de alguma artéria coronária e/ou em condições as quais não há estrutura, diâmetro arterial compatível com o stent convencional. A questão é que o hospital não oferece este dispositivo aos usuários, o qual, pelo menos, até o término das entrevistas deste estudo, não era padronizado e nem disponibilizado pelo Sistema Único de Saúde.

Nesse sentido, em tons de pioneirismo, "sob orientação do Ministério Público" e "acordo entre a Secretaria Municipal de Saúde de Uberaba e os representantes da área de cardiologia e hemodinâmica do HC/UFTM", a Ouvidoria do Hospital de Clínicas "pactua" e "estabelece" as seguintes regras:

CONSIDERANDO que, o "Stent Farmacológico" não é padronizado pelo Sistema Único de Saúde-SUS, somente liberado via judicialização;

CONSIDERANDO que, o acordo entre Secretaria Municipal de Saúde e o HC/UFTM será disponibilizado via REQUERIMENTO ADMINISTRATIVO, elaborado por esta Ouvidoria que qualificará o paciente e anexarão os relatórios médicos e, encaminhará ao setor de Regulação e Departamento de Compras da SMS;

CONSIDERANDO que, pacientes de outras Comarcas que necessitarem de implante de "Stent Farmacológico" será feito por esta Ouvidoria requerimento com todas as informações médicas da necessidade do implante, orientando ao cliente protocolar junto ao Ministério Público de sua cidade;

Por fim, cabe ressaltar que, a atitude tomada pelo Secretário Municipal de Saúde e referendada pelo Conselho de Saúde enaltece os cuidados com os cidadãos uberabenses na valorização da saúde e sua melhoria. A Administração Pública demonstra com tal gesto a eficiência e eficácia na efetivação de Políticas Públicas na área da saúde, em que, o Município atendeu a 28 pacientes em Requerimento Administrativo, 05 via judicial. E esta Ouvidoria fez 07 Requerimentos a outros Municípios (E. Souza, 2014, pp. 1-2).

$\mathrm{Na}$ nossa visão, não desconsiderando os possíveis benefícios do "stent farmacológico", o que se observa nesta situação é, além da intenção mercadológica de

\footnotetext{
${ }^{34}$ Araújo, Lima e M. Ferraz (2007) analisaram o Impacto do Stent Farmacológico no Orçamento do Sistema Único de Saúde. Para os autores, os Stents farmacológicos representam opção adicional para o tratamento da doença arterial coronariana, sendo essa tecnologia considerada importante inovação, para a qual pode ser necessário financiamento adicional, no curto prazo, para permitir incorporação ao Sistema Único de Saúde brasileiro. Os autores ainda destacam, conforme dados do Ministério da Saúde, que no ano de 2003, o Sistema Único de Saúde (SUS) financiou a realização de 30.666 angioplastias coronarianas com implante de stent e de 19.909 cirurgias de revascularização do miocárdio, totalizando aproximadamente R \$ 281 milhões em despesas.
} 
incorporação da tecnologia, a naturalização/institucionalização da judicialização da saúde como único critério de acesso ao procedimento especificado. Ultrapassa, como já alertava Baptista, C. Machado e Lima (2009), o risco de se desenvolver a via judicial como principal meio para se garantir o acesso aos medicamentos ou procedimentos. Situação também verificada por Chieffi e Barata (2010), que observaram crescimento da demanda pela ação judicial de dois medicamentos, antecedendo a incorporação dos mesmos no programa do SUS.

Outra questão é a consequente responsabilização, via mandatos judiciais, dos municípios que legal e estruturalmente não são "responsáveis" pelo financiamento das ações terciárias. Nesta situação, o Poder Judiciário nega categoricamente os princípios de regionalização e hierarquização do SUS.

Teve um paciente que eu paguei quase noventa mil reais em stent farmacológico (S.MMP1.27).

Eu estou muito preocupada com a questão do stent farmacológico, que vai estourar para mim a qualquer momento e eu não tenho nenhum recurso, eu estou sabe? Quando você tá assim.... É hoje que eu vou ter que responder por isso? (S.MMP-1.28)

É isso que eu vou te falar, o que que acontece! A ouvidoria do Hospital Escola fez um relatório da situação do paciente, mas ela não tem que identificar o responsável, porque a ouvidoria tá careca de saber que, se é tripartite e se o alto custo não é responsabilidade do município, ele não teria que identificar ninguém, porque nesse momento eu poderia fazer minha negativa, fazendo a justificativa de que o stent farmacológico está dentro do procedimento da internação, automaticamente, se ele está num hospital de alta complexidade, então, teoricamente, o pagamento desse procedimento não é meu de forma alguma. Então eu poderia fundamentar a minha negativa e a defensoria poderia ter entrado apenas contra o Estado e a União, mas não! Como eles identificaram a Secretaria Municipal de Saúde, acabou que eu também tive que ser intimada e nessa intimação eu tive que fornece, porque o paciente estava internado lá e, com risco de vida. Foram vinte e quatro mil reais! Que eu não precisaria ter arcado com isso. O Estado poderia ter arcado, porque na verdade a gente sabe que o Estado acaba não aplicando cem por cento do que ele deveria aplicar em saúde, então, nós estamos aplicando. É isso que é confuso, porque as nossas próprias entidades acabam por fazer algumas coisas de forma.... De forma incorreta como foi esse caso, porque eles identificaram a Secretaria Municipal (S.MGP-1.29).

O Sistema Único de Saúde é organizado e orientado pelo conjunto das Leis 8.080/90 e 8.142/90 que, baseadas nos preceitos constitucionais, determinam os princípios e diretrizes do SUS. Somam-se a estas uma infinidade de normas operacionais, portarias, protocolos, critérios técnicos gerais e específicos para o funcionamento e ordenamento financeiro dos diversos serviços que o compõem. Na prática da gestão do SUS, tais critérios e normas precisam ser seguidos pelos gestores, a fim de promover a política pública de saúde. 
Entretanto, este não parece ser o entendimento do Poder judiciário, que nega os princípios e critérios do SUS reduzindo-os à noção de consumo, haja vista a ocorrência de judicialização de medicamentos já oferecidos pelas farmácias básicas das Secretarias Municipais de Saúde, atendendo prescrições de medicamentos pelo nome comercial. "Nessa concepção, o direito à saúde se resume à oferta de medicamentos, reduzindo-se às ações curativas e paliativas, sem considerar o caráter fundamental de promoção e prevenção de doenças e agravos" (F.S. Vieira, 2008, p. 2).

Tem hora que eu sou judicializado por medicamento que eu tenho na farmácia básica! (S.MMP-1.30)

Quando eu não tenho o medicamento de marca, aí complica todo o esquema. Faz auxílio, vai para o jurídico, alguns trocam receitas, a gente não tem como monitorar isso tudo, mas fornece todos os medicamentos que eles procuram, porque eles também tentam, vão no Ministério Público e a gente também fica numa situação difícil (S.MMP-1.31).

De acordo com Gomes et al. (2014), o excesso das ações judiciais nos últimos anos, à medida que impõe gastos inesperados aos orçamentos das Secretarias Municipais de Saúde, desorganiza a atividade administrativa e impede a alocação racional dos escassos recursos públicos.

Vou te citar um exemplo claro, eu gastei o ano passado (2012) 4 milhões e quinhentos mil reais com mandatos judiciais e gastei com a atenção básica, para a cesta básica de remédios (RMUME), dois milhões e oitocentos mil. É justo? Quer dizer, eu gastei dois milhões e oitocentos mil para atender 46 mil pacientes e 4 milhões e quinhentos mil para atender 500 pacientes (S.MGP-1.32).

Chegou um ponto em que o usuário chega na rua e fala: "eu só consegui o remédio porque eu fui na juiza” (S.MMP-1.33).

Para os gestores a judicialização da saúde é uma "desigualdade injusta”, pois acaba privilegiando segmentos de usuários que têm acesso a informação, planos de saúde, consultas particulares, advogados e recursos financeiros, em detrimento daqueles desprivilegiados de educação e destituídos de renda, que só podem contar com o sistema público de saúde. Percepção semelhante também foi encontrada nos estudos de Barroso (s.d.), Campos Neto et al. (2012), M. A.A. Machado et al. (2011) e F.S. Vieira (2008).

Eu conheço uma determinada família aqui no município, que eu fui obrigado a comprar hormônio de crescimento e é uma das famílias mais abastadas do município. Eu sei. Eu conheço a família (S.MGP-1.34). 
Eu acabei de receber agora, você viu! Uma intimação da promotora dizendo que não houve cumprimento de mandatos judiciais na compra de medicamentos. Agora! Esses medicamentos foram pedidos via judicial por intermédio de indivíduos que tinham condição de pagar advogado. Ele contratou um advogado para isso. Ora! Se esse indivíduo tem condição de pagar um advogado, você não acha que é injusto o que ele está fazendo com o resto do pessoal da nação que realmente necessita desse medicamento? Ele fura a fila! E no momento que ele fura a fila o que é que ocorre? Ele nos coloca em uma situação difícil, ou seja, eu deixo de atender 100 para atender 1, pelo mesmo valor. É uma "Escolha de Sofia", você tem que fazer (S.MGP-1.35).

No depoimento abaixo, podemos observar dois movimentos, primeiro, além da já observada institucionalização da via judicial como critério de acesso a recursos e procedimentos do SUS, observa-se aqui, a naturalização da judicialização como "instrumento de gestão" que "resguarda" o gestor de uma ação, muitas vezes, tomada em desfavor aos princípios e diretrizes do SUS. Segundo, constata-se a impossibilidade dos moradores dos pequenos municípios em partilhar dos mecanismos judiciários como defensorias públicas, advogados, fóruns, e até mesmo da própria judicialização como acesso a recursos no âmbito do SUS. Creio que esta situação de privação coletiva seja o que podemos denominar de exclusão social.

Então, acaba que a gente nunca chega a ter ação judicial, a gente sempre faz antes sabe? Por isso que eu não tenho demanda judicial. Não é o correto, até tem vez que eu falo "gente, entra judicialmente", que a gente fica até mais resguardado né? Quando entra judicialmente, quando você compra, você tem a ordem judicial, você está resguardado. Eu tenho medo dessas coisas, para fugir da judicialização, a gente acaba fazendo coisa errada, comprando sem licitação, compra um, outro! E aí vem a dificuldade, mais uma dificuldade, porque aqui não tem nada (Fórum, escritório de advocacia, etc.). Pra judicializar tem que ir na cidade vizinha e normalmente o usuário não vai (S.MPP-1.36).

Diante do exposto, observa-se que a proteção judiciária dos direitos sanitários, concebidos originalmente para serem operados como direitos de natureza coletiva, nega os princípios do SUS e acaba pulverizada em milhares de pedidos de tutelas individuais, ajuizados, via de regra, por advogados privados ou Defensoria Pública. Tais conflitos, originariamente de natureza coletiva, são individualizados na via processual e encontram tutela no sistema judiciário, multiplicando a Desigualdade Social no interior do Sistema Único de Saúde, dificultando ainda mais a gestão de uma saúde pública marcada historicamente pelo subfinanciamento (Bisol, 2009).

É central o papel do médico nos processos de judicialização, não como culpado, mas reificado como instrumento do mercado. O que se vê, é um conjunto de estratégias de extensão de mercado focalizadas especialmente neste profissional, principal agente a operar a 
certificação das necessidades de saúde e das modalidades legítimas de responder às mesmas (Camargo Junior, 2007).

Resta a toda sociedade o risco de se buscar a saúde por meio do consumo das “mercadorias propiciadoras de saúde”. Como assevera Bauman (2008b), em nossa sociedade neoliberal, "o consumo é tratado como vocação e ao mesmo tempo um direito e um dever humano universal que não conhece exceção" ${ }^{35}$ [itálicos nossos] (p. 73). A esse respeito o autor destaca: "a sociedade de consumidores não reconhece diferenças de idade ou gênero (embora de modo contrafactual) e não lhes faz concessões. Tampouco reconhece (de modo gritantemente contrafactual) distinções de classe" (p. 73).

Acreditamos que o maior problema da Judicialização da saúde esteja ligado ao fato de os conflitos de classe historicamente construídos na sociedade se estenderem ao Estado e à aplicação do Direito Sanitário, de modo a determinar a falta de alternativas à reprodução da desigualdade social dentro do Sistema Único de Saúde Brasileiro (J. Souza, 2009).

É em um contexto abrangente e multivariado dos determinantes sócio-históricos da saúde, baseado em um conhecimento ampliado advindo da prática, explicitando a construção do cuidado em saúde dentro de uma perspectiva de múltiplos enfoques, com vistas à garantia da resolutividade, que se deve interpretar o direito à saúde. "Não se trata apenas de determinar se o Estado deveria ou não fornecer determinado medicamento, cirurgia etc., mas sim se as políticas estatais são, em sua totalidade, adequadas para enfrentar os determinantes complexos da saúde da população em geral” (O.L.M. Ferraz \& F.S. Vieira, 2009, pp. 225-226).

\subsubsection{Anomia}

Considerada fora de qualquer contexto histórico particular, a anomia se refere aos problemas de controle social ${ }^{36}$. A coerção cultural é ineficaz: os valores estão ausentes ou em conflito, os fins não estão ajustados às oportunidades estruturais, ou, ao contrário, os indivíduos não estão adequadamente socializados às diretrizes culturais. Qualquer que seja seu significado particular, a anomia é um estado social de anarquia ou de ausência de normas; o conceito incide sempre na relação entre indivíduos e as forças coatoras do controle social. Durkheim

\footnotetext{
35 Sob a perspectiva neoliberal, qualquer semelhança ao Art. 196 da constituição ("A saúde é direito de todos e dever do Estado") não é mera coincidência. De certa forma, sob a hegemonia do neoliberalismo e da reificação, o consumo substitui a saúde, a qual deixa de ser um direito universal e transforma-se em uma mercadoria, que todos podem consumir. O consumo da saúde passa ser universal, ele não conhece exceção, desde que se possa pagar. É a famosa meritocracia.

${ }^{36}$ Vale destacar que neste ponto, a categoria controle social, foi entendida apenas como controle do Estado ou do empresariado sobre as massas, ou seja, no seu sentido coercitivo sobre a população.
} 
supunha que o egoísmo, a competição insaciável e a ausência de sentido e de objetivos poderiam ser as reações prováveis daqueles que vivem em uma sociedade anômica (Horton, 2004, p.79).

Para Horton (2004), a definição clássica de anomia, em Durkheim, apresenta uma condenação do individualismo e de sua racionalização nas doutrinas de classe média, do liberalismo econômico e político. O conceito descreve criticamente sociedades onde o interesse econômico individual não apenas foi reificado, mas elevado à categoria de um fim coletivo. "Como consequência desta situação, os valores e as atividades econômicas tornamse segmentados de todas as outras esferas da vida social, dominando-as” (p. 80).

$\mathrm{Na}$ nossa visão, a anomia refere-se aos obstáculos que existem para o funcionamento ordenado do Sistema Único de Saúde.

Nessa perspectiva, o primeiro obstáculo evocado pelos gestores foi a Regionalização da saúde, ou melhor, a "ineficiência" desta.

Na Norma Operacional Básica (NOB) de 1993, a regionalização é compreendida como “articulação e mobilização municipal que leve em consideração características geográficas, fluxo de demanda, perfil epidemiológico, oferta de serviços e, acima de tudo, a vontade política expressa pelos diversos municípios de se consorciar ou estabelecer qualquer outra relação de caráter cooperativo" (CONASS, 2011b, p. 103).

A implantação das ferramentas dessa regionalização, quando elas acontecem, elas estão acontecendo de formas pontuais e não são sistêmicas e aí o que que acontece? Essas formas pontuais depois elas se quebram e o sistema não funciona como um todo quando fica só uma parte, fatalmente, não vai dar certo, porque se aquela parte que está ali depende para funcionar bem de uma outra superior que depois não foi implantada, fatalmente é fatídico de não dar certo (S.MGP-1.37).

O problema maior que a gente tem é que você tenta resolver o teu problema dentro do município, mas quando dentro da sua competência você não consegue, tem que passar para a competência seguinte e você já não consegue. E aí você tem que partir para o jogo político, liga para o para o Superintendente da Regional, liga pra gestor da alta complexidade, porque o da alta você não tem acesso com nada, e.... A nossa referência de alta complexidade é Uberaba. E Uberaba não se acha responsável por ela (S.MMP-1.38).

Mas não funciona é pelo processo que foi criado, a sistematização da PPI, ela não funciona porque ela ocorre através de reunião de gestores junto com o Estado, aonde se faz pactuações (acordos) em uma sala fechada onde todo mundo é bonitinho e a cidade faz tudo. Pode deixar que eu faço, deixa que eu faço, eu tenho oftalmologista, eu tenho cirurgião, eu tenho cardiologista, eu tenho tudo! Pode deixar que eu faço. Aí fica tudo bonitinho, aprova-se isso em uma reunião Intergestores CIB, mas quando vai se jogar a prática, quando coloca o usuário o próprio município que se responsabilizou em fazer o procedimento ele não dá conta, aí cai à ficha, aí ele fala assim: eu não estou dando conta nem do meu usuário vou ter que atender usuário de outra cidade? Aí o prefeito chega e fala assim: "não! O cara da cidade vizinha não vota em mim! Você tem que atender o cara que vota em mim". Aí não funciona, se for desse jeito a regionalização está fadada a sumir e cada um olhar para seu 
umbigo. Aí não fica uma regionalização fica um sistema totalmente municipalizado mesmo (S.MMP-1.39).

O modelo implantado hoje exige que um município Médio, como no caso de Araxá, dê apoio a outros 7 municípios, ele não tem estrutura pra ele né? Então o mínimo de organização que eu consegui dava no máximo para atender Araxá, como em algumas áreas eu tinha folga aí dava para atender os outros (S.MGP-1.40).

Na Constituição Federal de 1988, o artigo 198 inscreve que “As ações e serviços públicos de saúde integram uma rede regionalizada e hierarquizada e constituem um sistema único, organizado de acordo com as seguintes diretrizes: descentralização, atendimento integral e participação da comunidade" [itálicos nosso] (CONASS, 2011b, p. 39).

Este artigo demonstra a interdependência entre o processo de regionalização e os processos de descentralização, integralidade e participação da comunidade.

Nesse sentido, seguramente, a não operacionalização da regionalização, identificada no cotidiano dos serviços de saúde, impõe a anomia aos gestores e desafios à concretização dos princípios de universalidade, descentralização e hierarquização, ou seja, do próprio SUS.

O segundo obstáculo evocado pelos gestores foi o Financiamento, e neste quesito a anomia pode ser observada no (sub) financiamento; na falta de autonomia para utilizar o recurso e na corrupção.

Agora a saúde precisa de mais recursos, os valores pagos pelo SUS tem que ser melhorados. O sistema fica capenga, tá faltando uma perna, porque precisa de pagar o material para fazer a cirurgia eletiva, eu não tenho recurso aí o município tem que subsidiar. Eu subsidio aqui, mas eu tenho que atender a micro que teoricamente cada prefeito dos outros municípios precisariam fazer o subsidio equivalente ao deles. Eles não fazem e eu não posso pagar para os outros. E o SUS só me cobra que eu atenda a micro, mas não me fala de subsidio e eu estou atendendo! Depois quem paga o déficit? E aí então isso se torna um círculo vicioso no processo (S.MGP-1.41).

S.F. Silva (2011) e Mendes (2013) reforçam que o financiamento atual é uma das principais dificuldades para que o sistema de saúde e, por conseguinte, as redes regionalizadas contem com recursos suficientes para atender as necessidades assistenciais.

Em relação a utilização dos recursos o que se observou, em todos os municípios, foi o centralismo burocrático. Detecta-se com facilidade a presença de uma configuração sociopolítica caracterizada pela centralidade no executivo municipal. Tal centralidade determina uma relação casuística, sob o ponto de vista hegemônico da política partidária, entre o secretário de saúde e o prefeito, bem como entre o prefeito e a população. 
Primeira é a interferência do executivo municipal na gestão financeira da saúde, essa ganha disparada, onde verbas carimbadas acabam indo pro caixa da prefeitura né? E outras mais como indicação do servidor que muitas vezes não tem perfil nenhum pro cargo (S.MGP-1.42)

Aqui nós chegamos a $26 \%$ no total. É lógico que tem muito "camuflamento" com os gastos da saúde, mas chegou a $25 \%$ em um ano e $26 \%$ no outro. Mais o transporte quase todo da prefeitura é bancado pela saúde, tem "camuflamento" ai!! Não é uma contabilidade legal. A contabilidade tem que ser feita dentro da secretaria da saúde, a partir do momento que é caixa único eu não acredito que funcione não (S.MGP-1.43).

Como a regionalização não funciona não há uma distribuição de vagas que é cumprido, obriga-se os gestores a pagar procedimentos de média e alta complexidade, mas para aqueles apadrinhados pelo prefeito (S.MMP-1.44).

Vinha à ordem do prefeito: "é pra fazer". Na parte de oftalmologia também eu paguei muita cirurgia de catarata, mesmo falando assim: prefeito, nós temos campanha, vamos aguardar! Era assim: "Não! Não pode esperar". E assim! O paciente vinha com o pedido de cirurgia de um consultório particular, eu dizia para o prefeito: mas tem outro médico que faz por um preço melhor. E ele dizia: "não! Mais é o médico dele e ele, e ele pediu tanto", então tinha que pagar (S.MMP-1.45).

Eu tive muitos problemas com os recursos destinados às verbas da dengue, porque o irmão do prefeito era secretário de obras e queria que todas as obras de melhorias de infraestrutura, de limpeza urbana, entrassem com recurso de dengue. Eu dizia: como é que eu vou justificar ao Ministério da Saúde que durante doze meses eu contratei um trator por $R \$ 3.800,00$; que é da família dele! Durante a administração inteira eu tive esse problema e no finalzinho eu vi que poderia ser penalizada (S.MMP-1.46).

Segundo Fernandes (1996, citada por Meireles, 2004), a sociedade

encontra-se provisoriamente incapacitada para exercer sua ação de colocar freios às paixões humanas. (...) (A anomia) não deriva da inexistência de regras de intercâmbio mas da ausência de freios. Já não indica a desordem de uma etapa no curso de uma evolução progressiva e automática em direção à solidariedade orgânica, mas é um mal que ameaça a sociedade moderna" (p. 74).

"É como se a sociedade obliquamente mandasse-nos uma mensagem - é necessário fechar os olhos para a imoralidade, pois o anseio por líderes íntegros é repetidamente frustrado - e, de outro lado, submetesse-nos a uma ética cada vez menos praticada por nossos pares" (Meireles, 2004, p. 84). 


\subsection{Perspectivas apontadas pelos usuários Conselheiros Municipais de Saúde sobre o Sistema Único de Saúde (SUS)}

\subsubsection{Caracterização sociodemográfica dos Conselheiros Municipais de Saúde (Representantes dos Usuários)}

Como se pode observar no quadro abaixo, dentre os entrevistados, houve predomínio de homens $(66,6 \%)$, em faixa etária mais avançada $(44,4 \%)$, com baixo grau de escolaridade $(33,3 \%)$ e aposentados $(44,4 \%)$.

Os entrevistados eram representantes de várias entidades da sociedade civil sendo, 22,2\% representantes de organizações religiosas, 33,3\% de associações de bairros, outros $33,3 \%$ eleitos diretamente e um $(11,1 \%)$ convidado pelo grupo político do prefeito e indicado pela associação comercial. Vale destacar que em apenas uma organização religiosa houve eleição para escolha do representante a ser indicado para o Conselho Municipal de Saúde. Na outra organização religiosa e em todas as associações, o critério utilizado para a escolha do representante no Conselho foi a indicação, na primeira pelo líder religioso e nas associações pelos seus respectivos presidentes. Em relação os conselheiros que se manifestaram eleitos diretamente e independentes de entidades, um $(11,1 \%)$ manifestou ter participado da conferência e ter se candidatado ao conselho a convite da gestora.

A maioria dos entrevistados $(55,5 \%)$ exerciam as atividades de conselheiro há mais de um mandato, destes $11,1 \%$ estavam no segundo mandato, $33,3 \%$ no terceiro e $11,1 \%$ no quinto mandato.

Em relação aos planos de saúde 33,3\% os possuíam e os utilizavam da mesma forma que os gestores, em complementariedade ao SUS ou vice-versa, tendo um deles destacado:

O SUS é até melhor que muito hospital particular você tá entendendo? Eu uso mais o SUS, porque o SUS já tá mais fácil de você ir. O bom do SUS é que eles dão cirurgia, exames que eles pagam e que a gente não dá conta, tomografia, essas coisas mais caras eles conseguem dá pra gente. Porque a gente não consegue! Uma consulta hoje é duzentos reais, duzentos reais e cinquenta, a gente pobre não consegue dar duzentos e cinquenta em uma consulta entendeu? (C.MGP) 


\begin{tabular}{|c|c|c|c|c|c|c|c|c|c|}
\hline \multicolumn{2}{|c|}{ Participantes } & \multirow{2}{*}{$\begin{array}{c}\text { Idade } \\
\bar{~} \overline{57}\end{array}$} & \multirow{2}{*}{$\begin{array}{c}\text { Sexo } \\
\bar{M}\end{array}$} & \multirow{2}{*}{$\begin{array}{c}\text { Estado } \\
\text { Civil }\end{array}$} & \multirow{2}{*}{$\begin{array}{c}\text { Ocupação } \\
\text { Aposentado }\end{array}$} & \multirow{2}{*}{$\begin{array}{c}\begin{array}{c}\text { Possui } \\
\text { Plano de } \\
\text { Saúde }\end{array} \\
\text { Sim }\end{array}$} & \multirow{2}{*}{$\begin{array}{c}\text { Escolaridade } \\
\begin{array}{c}\text { Ensino médio } \\
\text { completo }\end{array}\end{array}$} & \multirow{2}{*}{$\begin{array}{c}\text { Tempo de } \\
\text { Conselho } \\
\text { 8 anos }\end{array}$} & \multirow{2}{*}{$\begin{array}{c}\text { Indicado por alguma entidade } \\
\text { Organização religiosa }\end{array}$} \\
\hline 1 & C.MGP & & & & & & & & \\
\hline 2 & C.MGP & 57 & $\mathrm{~F}$ & Viúva & $\begin{array}{l}\text { Costureira } \\
\text { Pensionista }\end{array}$ & Não & $\begin{array}{l}\text { Ensino médio } \\
\text { completo }\end{array}$ & 8 anos & Não \\
\hline 3 & C.MGP & 51 & M & Divorciado & Autônomo & Sim & $\begin{array}{l}\text { Ensino médio } \\
\text { incompleto }\end{array}$ & 4 anos & Associação de Bairro \\
\hline 4 & C.MMP & 72 & M & Viúvo & Aposentado & Não & $\begin{array}{l}\text { Fundamental } \\
\text { completo }\end{array}$ & 10 anos & Não \\
\hline 5 & C.MMP & 70 & M & Casado & Aposentado & Não & $\begin{array}{l}\text { Ensino médio } \\
\text { completo }\end{array}$ & 2 anos & Associação de Bairro \\
\hline 6 & C.MMP & 70 & M & Casado & Aposentado & Não & $\begin{array}{c}\text { Ensino } \\
\text { fundamental } \\
\text { incompleto }\end{array}$ & 17 anos & Não \\
\hline 7 & C.MPP & 49 & M & Casado & Microempresário & Sim & $\begin{array}{l}\text { Ensino médio } \\
\text { completo }\end{array}$ & 2 anos & Associação comercial \\
\hline 8 & C.MPP & 28 & $\mathrm{~F}$ & Casada & Locutora & Não & $\begin{array}{l}\text { Ensino médio } \\
\text { incompleto }\end{array}$ & 9 meses & Associação de Bairro \\
\hline 9 & C.MPP & 35 & $\mathrm{~F}$ & Casada & $\begin{array}{c}\text { Auxiliar } \\
\text { Administrativo }\end{array}$ & Não & Secretariado & 3 anos & Organização religiosa \\
\hline
\end{tabular}

Figura 10 - Perfil sociodemográfico dos usuários conselheiros participantes do estudo 


\title{
3.2.2. Categoria 2 - Racionalidades do Controle Social
}

\author{
"Buscar a real identidade na aparente \\ diferenciação e contradição, e descobrir a \\ substancial diversidade por trás da aparente \\ identidade é a mais delicada, incompreendida e, \\ contudo, essencial capacidade do crítico das \\ ideias e do histórico do desenvolvimento social"
}

Gramsci.

De acordo com Correia (2008), o "controle social" tem origem na sociologia e de maneira geral "é empregado para designar os mecanismos que estabelecem a ordem social, disciplinando a sociedade e submetendo os indivíduos a determinados padrões sociais e princípios morais" (p.104).

Bravo (2001 citada por Bravo, 2006) destaca que:

Historicamente, a categoria controle social foi entendida apenas como controle do Estado ou do empresariado sobre as massas. É nessa acepção que quase sempre o controle social é usado na Sociologia, ou seja, no seu sentido coercitivo sobre a população. Entretanto, o sentido de controle social inscrito na Constituição é o da participação da população na elaboração, implementação e fiscalização das políticas sociais. Esta última concepção de controle social tem como marco o processo de redemocratização da sociedade brasileira com o aprofundamento do debate referente à democracia [itálicos nossos] (p. 3).

\section{Para Correia (2006),}

A área da saúde foi pioneira neste processo devido à efervescência política que a caracterizou desde o final da década de 70 e à organização do Movimento da Reforma Sanitária que congregou movimentos sociais, intelectuais e partidos de esquerda na luta contra a ditadura com vistas à mudança do modelo "médico-assistencial privatista" para um Sistema Nacional de Saúde universal, público, participativo, descentralizado e de qualidade. A participação da comunidade e a descentralização tornam-se diretrizes do novo Sistema Nacional de Saúde na Constituição Federal de 1988 (p. 01).

O que se pode observar historicamente, e de fato, é a construção de uma identidade coletiva, através das semelhanças pelas carências sociais, que balizou o esforço em torno da luta pela consolidação de direitos básicos do cidadão, voltados a imprimir na Constituição 
Federal de 1988, os fundamentos de uma moderna cultura social, ou seja, a cultura dos Direitos Sociais (Maciel, 2010).

Nessa perspectiva, abordaremos as Racionalidades do Controle Social no campo da complexidade que se apresentam, procurando identificar processos psicossociais implicados na constituição da identidade com a política pública de saúde e com a memória da luta de classes, conforme organograma abaixo.

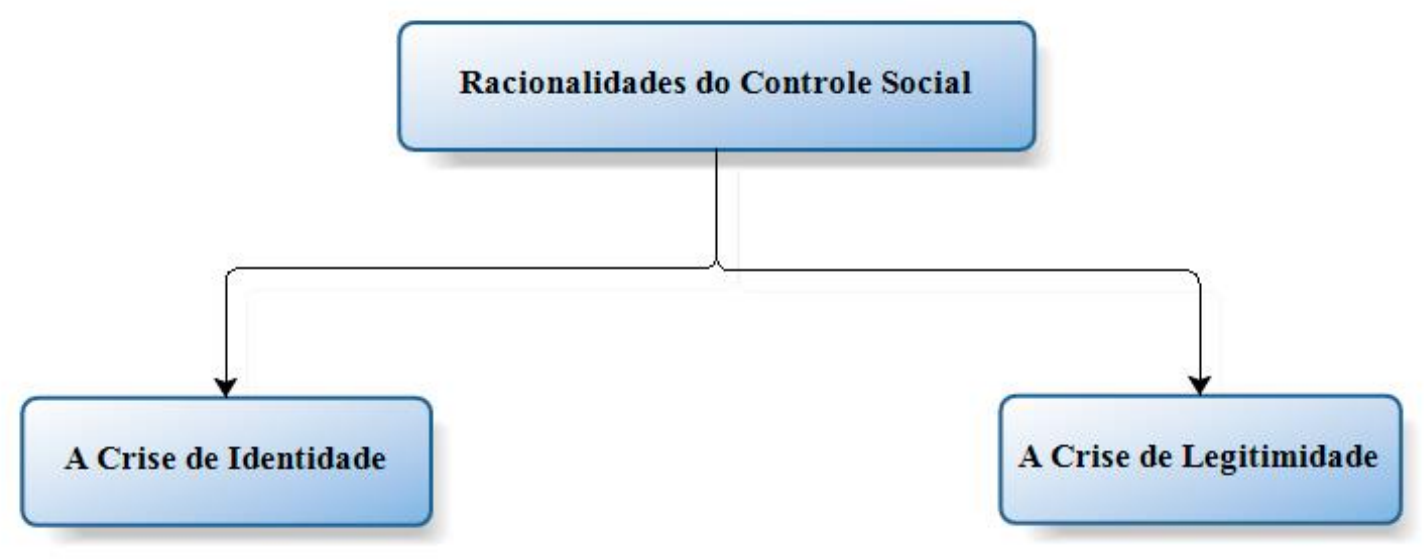

Figura 11 - Organograma demonstrativo das unidades temáticas da Categoria 2, Ribeirão Preto, 2015

\subsubsection{1 - A crise de Identidade}

Pelos depoimentos dos usuários conselheiros de saúde foi possível identificar que é na luta cotidiana pela manutenção das necessidades materiais de sobrevivência que surgem os atores que se envolvem nos espaços de participação popular. Entretanto, observou-se que grande parte das motivações para o ingresso e participação dos sujeitos nos Conselhos Municipais de Saúde (CMS) foram questões individuais como a dificuldade de acesso aos serviços e recursos do Sistema Único de Saúde ou manutenção do status quo para ganhos e benefícios de outras ordens.

Nossa, eu me tornei conselheira, através da minha luta, que eu tenho um filho especial. Então! Como eu não tinha um apoio de ninguém, vamos dizer assim né? Orientação de saúde, o serviço de saúde não me apresentava apoio até então! Foi através dessa minha corrida né? Com o meu filho, com as minhas buscas né? (C.MGP-2.1) 
Então! Como é que ele ia conseguir os tratamentos que ele consegue pra esposa dele se ele não tivesse no conselho? Eu falei - "como cidadão, pelo seu direito natural”. Isso não é justo! Muitas outras pessoas estão no conselho e usam dessa situação do conselho pra arrumar emprego pra filho, pra parente, isso é natural, isso acontece lá e aqui em menor grau, vamos dizer assim (C.MGP-2.2).

Trata-se de um contexto que revela a reificação, que ameaça à justiça social, que se encaixou perfeitamente em um liberalismo econômico que deseja acima de tudo reprimir a identidade e a memória das lutas de classe e dos Direitos Sociais, determinando que os problemas coletivos sejam tratados apenas em âmbito individual.

Sob esta perspectiva identificou-se que os conselheiros têm pouca compreensão de seu papel e consequentemente de todo arcabouço legal e prático que dele se origina. Desconhecem, quase que em sua maioria, o caráter deliberativo do conselho, não tendo assim a compreensão do poder que lhes é atribuído, nem mesmo identidade com a política pública de saúde e/ou com a memória da luta de classes.

Então! Tem um grupo de conselheiros que é conselheiro de reunião, eles vão todo mês na reunião, mas no dia a dia eles não fazem nada, e é um número muito grande, infelizmente (C.MGP-2.3).

Se a lei tá aqui, não é cumprida e eu não cobro, no direito isso tem um nome que é aceitação tácita, eu não te perturbo, você não me perturba e nós ficamos no zero a zero (C.MGP-2.4).

Os conselheiros têm se dedicado a ações burocráticas em detrimento da defesa dos interesses populares. Pressionados por prazos vencidos ou prestes a vencer, sentem-se obrigados a deliberarem por políticas e aprovarem prestações de contas mesmo sem o entendimento do descrito. O grande volume de documentos não permite que estes sejam analisados durante as reuniões. Via de regra, prestações de constas, projetos, etc., são aprovados com receio de que a não aprovação possa prejudicar a população e/ou captação de recursos futuros para o município, argumento sempre utilizado pela gestão quando se discute os diversos documentos que precisam ser avaliados pelo conselho.

Porque tem aquela situação, arruma tudo quanto é parafernália e põe pro conselheiro analisar (C.MGP-2.5).

Nós cobramos, mas, sempre, apresentam atrasado sabe? E há uma questão muito séria pela aprovação ou não do conselho né? Porque como você vai aprovar uma coisa que chega no atropelo. Mas às vezes o município perde verba por atraso na aprovação e você aprovar com ressalva é muito ruim pro município né? (C.MGP-2.6)

Tem muita demanda de urgência não programada, vamos dizer assim, urgência da secretaria que deixavam "acontecer" e levavam pro conselho aprovar correndo. Então isso gerava um 
transtorno, e às vezes a gente pedia vistas do conselho o que ficava meio complicado (C.MGP-2.7).

Outro aspecto importante, refere-se à postura de consentimento frente ao que lhes é apresentado pelo governo e certa "naturalização" das irregularidades, o que na verdade demonstra uma identidade com o poder burocrático. Como nos estudos de Bispo Júnior et al. (2006) e Bispo Júnior \& Sampaio (2008), o Conselho Municipal de Saúde apresenta-se mais como um espaço de homologação de decisões tomadas pelo executivo, do que um espaço democrático de formulação e proposição de políticas de saúde locais. Verifica-se ainda, em conformidade com o último estudo, "certa conivência e omissão em relação ao acompanhamento da gestão financeira, visto que, mesmo diante de irregularidades, as contas sempre são aprovadas" (p. 406).

Como se diz, o que ficar, assim, aprovado lá é o que a gente faz né. E não tem, assim, um que vem aqui reclama alguma coisa, que já sai de lá decidido (C.MPP-2.8).

Nós sabemos que a verba que é destinada pra saúde, nem sempre ela é usada na saúde. Geralmente ela tem algum "desviozinho" para alguma parte; igual da educação, nós somos carecas de saber disso, inclusive nos vemos em várias cidades muitos prefeitos estão sendo processados por causa desses desvios de verba, nós sabemos disso! (C.MMP-2.9)

Ou, ainda, utilizando a linguagem gramsciana, de acordo com Liguori (2003, p. 186, citado por Simionatto, 2009),

pode-se dizer que o Estado "educa o consenso", através dos "aparelhos privados de hegemonia", especialmente através dos meios televisivos e dos grandes monopólios privados da mídia, mecanismos fortalecedores da fragmentação social das classes subalternas, criando um novo "senso comum", "do qual são expelidos a política, a participação, a vida em relação aos outros, o sentido de comunidade" (pp. 42-43).

O que acontece de fato é a reificação da sociedade civil à esfera estatal, que ocorre através de diferentes mecanismos e "torna indistintas as diferenças de classe, fortalecendo a subalternidade" (Simionatto, 2009, p. 42). A reificação, portanto, está na base das decisões naturalizadas. Prevalece, neste contexto, o sentimento de desqualificação técnica para o questionamento de programas, projetos, ações, prestações de contas, dentre outros documentos que compõem uma estrutura burocratizada e pouco clara no processo de organização dos serviços de saúde. Tal contexto evidencia-se no relato que se segue, bem como em outros estudos (Bicalho, 2003; Bispo Júnior et al., 2006; Bispo Júnior \& Sampaio, 2008; Zambon \& Ogata, 2011). 
Então! O SUS hoje está pautado em planejamento. É o que está tomando o nosso tempo, Plano Municipal de Saúde, LDO, PPA, e a gente não tá conseguindo. A 141 jogou tanta responsabilidade que o conselho não tá conseguindo analisar tudo aquilo que a legislação colocou pra ele dar parecer. Então, estamos patinando, eu acho que vai ser uma coisa boa lá na frente, mas agora, precisa profissionalizar o conselho. $O$ conselho vai ter que ter um advogado, vai ter que ter um contador (C.MGP-2.10).

Agora! A secretaria de saúde nunca nos negou a prestar informações e fornecer técnicos que nos ajudem a pensar, mas quando tem pessoas que tem nível de conhecimento suficiente a coisa flui, quando não tem eles dirigem. Então os técnicos que vem nos apoiar pra esclarecer a situação, vem muito vinculado, eles vem direcionando tudo aquilo pra ajeitar, não vem dar um parecer isolado (C.MGP-2.11).

Eis que se apresenta o fetiche da ideologia da competência técnico-científica, que na prática, de acordo com Chaui (2000b), é a ideia de que há na sociedade os que sabem (os especialistas) e os que não sabem (os cidadãos), que os primeiros são competentes e têm o direito de mandar e de exercer poderes, enquanto os demais são incompetentes, devendo obedecer e ser mandados. Transfere-se o poder de decisão para aqueles que têm "conhecimento" e o Controle Social passa a ser coisa de técnicos, de especialistas e não de cidadãos.

Esta estrutura reificada, especializada e burocratizada de funcionamento dos conselhos favorece a desarticulação e a perda de identidade dos conselheiros, bem como a não compreensão dos processos ali apresentados e tratados pelo Estado como necessidades e prioridades para a saúde da população. Nesta dinâmica de funcionamento, tornam-se os conselhos espaços de manutenção da ordem social vigente, afastando-se de suas bases e perdendo seu caráter singular de apoio popular. Praticamente inexistem espaços de diálogo e escuta dos usuários conselheiros sobre suas percepções e demandas coletivas, originárias do contexto vivenciado cotidianamente pelos usuários do SUS. Tão pouco existem espaços de relação entre os representantes e seus representados para discussão e defesa das políticas públicas. Quando estes espaços, por ventura se apresentam, acabam sendo reificados a um caráter reivindicatório de resolução individual e imediatista.

Eu sou procurada na minha residência né? Eu virei mesmo, vamos dizer, um ponto de referência do meu setor. Procuram sabe pra saber como que consegue uma consulta, como consegue um encaminhamento, até mesmo pra levar até o pronto atendimento, pra levar num consultório, pra tá acompanhando um paciente no domicílio, eu acompanho sempre (C.MGP2.12).

De acordo com Fraser (2002), para neutralizar a ameaça da reificação precisamos de revisitar o conceito de reconhecimento/pertencimento. "Necessitamos de uma concepção nãoindenitária que desencoraje a reificação e promova a interação entre as diferenças, o que 
significa rejeitar as definições habituais de reconhecimento" (p. 14), ou seja, o individualismo, a meritocracia e o economicismo dominante. Para a autora, o reconhecimento é visto através da lente da identidade. Deste ponto de vista, o que se requer reconhecimento é a identidade sócio-histórico-cultural específica dos grupos, visando "a superação da subordinação, procurando instituir a parte subordinada como membro pleno da vida social, capaz de interagir paritariamente com os outros" (p. 16).

\subsubsection{2 - A crise de Legitimidade}

De acordo com Lima (2001), a defesa da participação da população nas deliberações sobre as políticas de saúde sempre esteve presente como um dos princípios da reforma sanitária brasileira. Postulava-se não só a democratização do acesso aos bens e serviços de saúde, mas também a democratização do acesso ao poder.

Nesse contexto, os Conselhos de Saúde devem ser compreendidos como instâncias de definição, decisão e controle das principais diretrizes e metas governamentais, "embora não quebrem com o monopólio estatal de produção e execução das políticas públicas, podem (e devem) obrigar o Estado a seguir as diretrizes elaboradas em cogestão com a sociedade civil” (Borba \& Lüchmann, 2010, p. 230).

Conforme Lei no 8.142/90, “a representação dos usuários nos Conselhos de Saúde e Conferências será paritária em relação ao conjunto dos demais segmentos" (CONASS, 2011b, p. 61). A paridade dos usuários em relação aos demais representantes é considerada importante indicador do nível de legitimidade, democratização e autonomia dos Conselhos de Saúde. A Resolução no 333/2003 determina a seguinte distribuição de vagas: $50 \%$ de entidades de usuários; $25 \%$ de entidades dos trabalhadores de saúde; $25 \%$ de representação de governo, de prestadores de serviços privados conveniados, ou sem fins lucrativos (Ministério da Saúde, 2003).

De acordo Lavalle, Houtzager e Castello (2006), observa-se, desta forma, "uma abertura do poder Executivo à participação de atores societários - organizações civis investidos juridicamente como representantes de determinados segmentos e interesses da população no desenho, na implementação e na supervisão de políticas públicas” (p. 43).

Nessa perspectiva, como destacam Santos e Avritzer (2002, citados por L.C. Oliveira \& Pinheiro, 2010), os conselhos de saúde não estão imunes aos riscos de perversão e 
cooptação empreendidos por aqueles interessados na manutenção do status quo, os quais representam os interesses hegemônicos da agenda neoliberal.

Como nos estudos de Bispo Júnior e Sampaio, 2008; Borba e Lüchmann, 2010 e Zambon e Ogata, 2011, o que se observa nos depoimentos dos sujeitos são situações de predomínio de métodos não democráticos de seleção dos conselheiros no âmbito das entidades da sociedade civil e indicação de aliados pertencentes à chamada rede sociopolítica de apoio ao governo, o que coarta a legitimidade dos conselhos e fere a determinação de paridade inscrita na lei 8.142/90.

O presidente (da Associação de Bairro) não podia participar, então ele me indicou (C.MGP2.13).

Eu fui indicada pela gestora. Aí eu fui eleita na conferência (C.MPP-2.14).

Eu fui convidado pelo grupo político atual para participar, como eu tenho um comércio aqui na cidade, sou conhecido por todo mundo e como eu sou representante da associação comercial eu fui indicado como membro da associação e dos usuários (C.MPP-2.15).

Não há dúvidas que o controle social na atualidade, em especial nos serviços públicos de saúde, deva ser compreendido no eixo Estado - Sociedade Civil, fundamentalmente, se considerarmos que a representação da sociedade nos espaços de participação social tem se legitimado por meio das diversas organizações da sociedade civil. Organizações estas, que de acordo com M.K. Silva (2006), deveriam canalizar para a esfera pública os "problemas societários" que nascem e emergem do cotidiano das pessoas, viabilizando a construção de novas relações com o sistema político-institucional, que possibilitariam uma real democratização, na medida em que garantissem que o "fluxo de poder" fosse direcionado da Sociedade Civil para o Estado e não o inverso, como ocorre na tradição política autoritária brasileira.

Tal legitimidade vem sendo construída, no caso brasileiro, desde os anos de 1980 e 1990, período em que se observa a afirmação neoliberal, a (des)responsabilização do Estado pelo desenvolvimento econômico e social e a emergência de movimentos sociais, ONGs e outras formas associativas pautadas na ênfase ao voluntariado, na solidariedade, na defesa dos excluídos e de causas públicas, desvinculadas da obtenção de lucros, ou seja, "privadas, porém públicas" (Borba \& Lüchmann, 2010; Bravo, 2006). Assim, parece que a "justificativa moral - pelas causas que defende - se justapõe à justificativa procedimental (eleições) como fonte de legitimidade. Com efeito, multiplicam-se não apenas os tipos e atores, como os 
critérios de legitimação, complexificando ainda mais o entendimento acerca do fenômeno da representação" (Borba \& Lüchmann, 2010, p. 235).

Para Ammann (1980, citada por L.C. Oliveira \& Pinheiro, 2010), as "formas de organização associativista existentes deixam intactas as estruturas básicas que determinam a distribuição e o consumo dos bens e serviços societários em questão” (p. 2457).

Associado a estas questões e ferindo de morte a legitimidade do controle social, observou-se a influência do autoritarismo político, que de acordo com Chaui (2001), encontra fundamento dentro da nossa própria história sociocultural.

O Conselheiro é um cargo que ninguém quer pegar. Porque ali! Ali envolve muita coisa! Se brincar dá até inimizade. Porque é muito grave. A gente tem que fiscalizar tudo, o dinheiro que tem e em cidade pequena a gente fica marcado (C.MGP-2.16).

Assim, três colegas que eu indiquei né, chamei pra ir pra conferência, mostrei o que era, foi, gostou, foi eleito e está no conselho, mas às vezes assim, tem medo. Porque na realidade, você acaba mexendo com os poderosos, como se diz! (C.MGP-2.17)

Nesse diapasão, também emergem como elementos que comprometem seriamente a legitimidade do Controle Social. 1) a falta de diálogo; 2) não reconhecimento da importância do conselho por parte das autoridades; 3) não regularidade das reuniões; 4) falta de acesso às informações; 5) falta de interesse pelas demandas dos usuários; 6) naturalização do Secretário de Saúde como presidente do conselho e 7) importância do papel do gestor para a participação popular.

1) Ah! O diálogo! O diálogo com a administração, com a gestão é intransigente, geralmente não acata né? Acha que o conselho não tem aquele poder que nós conselheiros temos né? (C.MGP-2.18).

2) Eles precisam do conselho ali. Precisa do conselho para ter assinatura. Caso contrário a opinião nossa não tem valor nenhum. Eu falo porque a gente sabe (C.MPP-2.19).

3) São poucos os conselheiros que participam, tem reunião que tem dois, três, nem dá para fazer a reunião (CMMP-2.20).

4) Eu fui descobrindo que há um desinteresse da informação. Eles não querem que os conselheiros, que a comunidade fique a par do que realmente acontece, do que é o SUS sabe. Porque não é interessante o povo ficar sabendo! Porque se o povo ficar sabendo vai cobrar mais sabe? E por desinformação as pessoas não cobram porque acham que o SUS é de graça (C.MGP-2.21).

5) A maioria dos gestores simplesmente estão pendurados em um cargo político certo? E não tem interesse na continuidade de abertura, de avanço no atendimento do usuário (C.MMP-2.22). 
6) Quem preside o nosso conselho geralmente é o Secretário de Saúde. Aqui sempre foi o secretário. Aqui sempre foi assim. Porque o que, que é! Tudo quanto é que ele vai repassar somos nós que pedimos. Então eu não vou dizer que ele vai influenciar contra (C.MMP-2.23).

7) A participação popular depende da vontade da gestão. Porque se a gestão quiser publicizar as situações você consegue público. Se você não caminhar, porque não tem como o grupo de conselheiros fazer as coisas acontecerem naturalmente. Se o governo quer levar a gente pra uma reunião, então ele põe a público, faz um palanque, chama os trabalhadores, chama toda a sociedade e tal e consegue mobilizar. Se ele não quer ele cala, ele calando fica só a gente na vontade e no laço. Então depende muito da vontade da gestão (C.MGP-2.24).

Portanto, o controle social não é do Estado nem da sociedade civil, mas das classes sociais. Por isso é contraditório, pode ser de uma classe ou de outra, pois a sociedade civil é espaço de luta de classes pela disputa de poder. É a partir da compreensão de que o Estado garante a dominação de classe pelos instrumentos de coerção/consenso, incorporando as demandas da população, que se abre a possibilidade das classes subalternas defenderem seus interesses equivalentes àqueles que até o momento têm sido exclusivos das classes dominantes.

Nessa perspectiva, foi possível observar nos depoimentos abaixo, a participação no sentido de contribuir conjuntamente com a coletividade na luta pela garantia do direito à saúde. Em tal participação, ao melhor estilo marxista, pode-se observar que "os interesses são objetivos, estruturais, isto é, determinados pela posição que um grupo possui na estrutura das relações de produção, pela sua posição de classe. Isso implica que o fundamental para ação política de um grupo seja seu interesse de classe" (Vaitsman, 1989, p. 145).

Tem a força desse coletivo né, porque um só pode até tentar e consegue alguma coisa né, mas eu acho que no coletivo surge, surte mais efeito né (C.MGP-2.25).

Eu acho assim, eu não digo principal, a responsabilidade do conselheiro ela é única. É em defesa do SUS e dos usuários. Quer dizer que quando você está em defesa do SUS, você não está sendo nem a favor e nem contra o gestor, nem contra governo, é o SUS. Você pega a política pública do SUS que é o Sistema Único de Saúde e você tem que ter aquele compromisso. E nos momentos, vamos dizer assim, como o conselho é cogestor, o conselheiro vai se posicionar em favor de situações que beneficia a sua comunidade (C.MGP-2.26).

Com efeito, o controle social precisa ser problematizado dentro das contradições da sociedade de classes. Deve materializar-se através da efetiva participação da sociedade civil ${ }^{37}$ na condução das políticas sociais públicas.

\footnotetext{
${ }^{37}$ Conselheiros, usuários, organizações civis, associações comunitárias, profissionais da saúde e universidades.
} 
Um controle social desarticulado, desmobilizado e despolitizado sugere a privatização da saúde ao negar este espaço político de mediação entre o poder executivo e a sociedade, correspondendo ao fortalecimento dos centros privados onde se dá a decisão hegemônica dos estados nacionais (Chaui, 1992).

Em síntese, o que queremos aqui destacar é o ponto zero ou de convergência entre a crise de identidade e a crise de legitimidade do controle social que, oculto pela reificação, nada mais é que o esquecimento da memória da luta de classes e consequente afastamento dos usuários conselheiros de suas bases e da defesa mais premente das necessidades de vida da população.

3.3. Perspectivas apontadas pelos Usuários sobre o Sistema Único de Saúde (SUS)

\subsubsection{Caracterização sociodemográfica dos Usuários}




\begin{tabular}{|c|c|c|c|c|c|c|c|c|c|}
\hline \multicolumn{2}{|c|}{ Participantes } & Idade & Sexo & $\begin{array}{c}\text { Estado } \\
\text { Civil }\end{array}$ & Ocupação & $\begin{array}{c}\text { Plano } \\
\text { Privado de }\end{array}$ & Escolaridade & $\begin{array}{l}\text { Número de } \\
\text { Filhos }\end{array}$ & Renda Familiar \\
\hline 1 & U.MGP & 23 & M & Casado & Web designer & Não & $\begin{array}{l}\text { Superior } \\
\text { incompleto }\end{array}$ & 3 & 4 salários mínimos \\
\hline 2 & U.MGP & 67 & $\mathrm{~F}$ & Divorciada & Aposentada & Ipsemg & $\begin{array}{l}\text { Fundamental } \\
\text { incompleto }\end{array}$ & 8 & 1 salário mínimo \\
\hline 3 & U.MGP & 63 & $\mathrm{~F}$ & Viúva & Pensionista & Não & $\begin{array}{l}\text { Fundamental } \\
\text { incompleto }\end{array}$ & 2 & 1 salário mínimo \\
\hline 4 & U.MMP & 52 & M & Casado & Aposentado & Não & $\begin{array}{l}\text { Fundamental } \\
\text { incompleto }\end{array}$ & 1 & 2 salários mínimos \\
\hline 5 & U.MMP & 26 & $\mathrm{~F}$ & Solteira & $\begin{array}{l}\text { Garota de } \\
\text { programa }\end{array}$ & Não & $\begin{array}{l}\text { Fundamental } \\
\text { incompleto }\end{array}$ & 3 & 1 salário mínimo \\
\hline 6 & U.MMP & 31 & $\mathrm{~F}$ & Casada & $\begin{array}{l}\text { Presidente de } \\
\text { sindicato }\end{array}$ & Não & $\begin{array}{l}\text { Fundamental } \\
\text { completo }\end{array}$ & 1 & 3 salários mínimos e meio \\
\hline 7 & U.MPP & 38 & $\mathrm{~F}$ & Divorciada & Cozinheira & Não & $\begin{array}{l}\text { Fundamental } \\
\text { completo }\end{array}$ & 1 & 1 salário mínimo \\
\hline 8 & U.MPP & 42 & $\mathrm{M}$ & Solteiro & Reflorestamento & Não & Alfabetizado & 3 & 2 salários mínimos \\
\hline 9 & U.MPP & 36 & $\mathrm{~F}$ & Casada & Doméstica & Não & $\begin{array}{l}\text { Fundamental } \\
\text { incompleto }\end{array}$ & 4 & 2 salários mínimos \\
\hline
\end{tabular}

Figura 12 - Perfil sociodemográfico dos usuários participantes do estudo 


\title{
3.3.2. Categoria 3 - Relatos de vidas marcadas pela reificação.
}

\author{
"Apesar de tudo o que se pode dizer e escrever \\ sobre a infelicidade, sempre há o que descobrir \\ neste domínio. Curioso paradoxo, que dá, \\ definitivamente, à Vivência alguns passos de \\ vantagem sobre a Palavra" \\ Christophe Dejours, A loucura do trabalho
}

Concordamos com J. Souza (2009) quando assevera que todo conflito social é dramatizado em uma falsa oposição entre mercado divinizado e Estado demonizado, onde os reais conflitos sociais que causam dor, sofrimento e humilhação cotidiana para dezenas de milhões de brasileiros são tornados literalmente invisíveis.

A categoria Relatos de vidas marcadas pela reificação é uma tentativa de conferir visibilidade, pela voz dos usuários, ao que não se quer ver. Esses vários exemplos são, pois, variedades de uma mesma espécie: a reificação da saúde.

\section{Estigma}

Eu acredito no SUS, porque a população de renda baixa, somos nós os pobres né? Porque eu não gosto da palavra pobre, porque pobre é o demônio, eu falo pessoas simples, humildes né? Se não fosse o SUS, fariam o quê? Não teria remédio, não teria tratamento, não teria nada (U.MPP).

\section{Vulnerabilidade}

Eu acredito no SUS, como eu trabalho com a população carente né, eu tenho trabalhadores que me procuram, como eu te falei, que são cortadores de cana, que são pessoas que trabalham no pau de arara, que são aqueles trabalhadores sem condição nenhuma. Então eles vêm aqui e reclama, reclama muito, que não adianta ter esse monte de PSF aberto, esse monte de casa aberta, esse tanto de número de gente trabalhando e não ter o principal, que é o médico (UMPP).

Geralmente não tem médico. Então quase todas as vezes não tem médico, não tem como utilizar o PSF do meu bairro. Inclusive até, só tem médico no Pronto Socorro, a demanda dentro do Pronto Socorro da minha cidade é muito grande, tanto pela 
aquela pessoa que quebrou uma simples unha até por um acidente grande. Tudo é direcionado no Pronto Socorro porque os PSFs não têm médico (UMMP).

Os médicos especialistas que vem, por exemplo, os pediatras e os ginecologista, eles atendem no posto de saúde e mesmo assim pra você conseguir uma consulta com eles, com os especialistas, você fica quase um ano na fila pra aguardar (UMPP).

Eu acho que a saúde ela tem que tá em primeiro lugar, ela tem que tá abaixo de Deus. Abaixo de Deus tem que ser a saúde, ela tem que ter uma condição melhor pro seus usuários, porque muitas das vezes, igual eu te expliquei, às vezes você tá com uma doença simples e ela se torna uma coisa maior porque não teve recurso. Eu conheço, eu tive dentro da minha família um caso de um cidadão que estava doente e que não conseguiu chegar até o final, por ser difícil o acesso (UMMP).

\section{Discriminação}

E aí quando falha este pacto social de que a Constituição tá ali e tem que ser atendida, de que a governança tá ali e tem que funcionar dentro das instituições e aí você tem que partir pra uma linguagem, inclusive do século XIX, que é a de quem tem o porrete maior e o porrete que eu tinha era bater na imagem deles, na opinião pública, que foi a única coisa que realmente foi temível pro sistema. E eu não acho que eu saí melhor nesse processo pela forma como foi visceral, porque virou guerra, foi tudo ou nada (UMGP).

No final é tudo dinheiro, no final é o quanto você pode pagar. É complicado você pensar nisso né? Sobre todas as promessas da Constituição, sobre todas as promessas que o Estado a partir de 1988 prega pra nós. De todas as lutas sociais que se faz, você vê que no final tudo continua sendo dinheiro, é mais valorizado quem tem dinheiro (UMGP).

\section{Exclusão social}

Há uma reclamação muito grande dos trabalhadores de que não tem médico, por exemplo. Se eles adoecem, eles faltam do serviço porque já trabalha como cortador de cana, trabalhador da herbicida, da irrigação, às vezes eles adoecem e falta do serviço pra procurar o médico e chega no PSF não tem médico, então aí eles tem que socorre é no Pronto Socorro. Chega lá o Pronto Socorro nega esse atestado pro paciente a pedido das empresas grande que tem aqui na cidade que é a usina, dentro do hospital ela manda (UMMP).

Eu volto a destacar que existe a não cidadania, a não dignidade no processo, porque cada dia a mais que os bebês não são atendidos nas necessidades deles é um dia que pesa para que eles não possam andar, não possam falar, porque eles têm uma 
deficiência e o não atendimento daquilo que é necessário para o tratamento pode estar privando eles dá chance de desenvolvimento (UMGP).

Nós muitas vezes ganhamos as batalhas somente naquele momento, as conquistas não são definitivas. Muitas vezes o gestor fala, vamos dar pra eles pra acabar com esse problema e isso significa que na próxima necessidade você vai ter que usar uma força ainda maior pra conseguir o próximo objetivo. Você vai ter que usar uma energia, uma estratégia ainda maior. E o mais triste de tudo, além desta questão de administração, de poder e tudo mais, é você lá na frente ter que falar pro seu filho, se você não conseguir ganhar, que ele talvez tem alguma deficiência, que talvez ele não ande direito, que talvez ele tem dificuldade de aprendizagem porque você não teve dinheiro (UMGP).

O SUS é um sistema de saúde pro pobre sem qualidade, pro rico com muita qualidade. Quando um rico precisa de um algo mais complexo que o seu plano de saúde não vai atender, a priori, ele recebe tratamento do SUS. Então nós temos um SUS que atende com excelência as camadas vamos dizer assim mais abastadas, que eu vou chamar das camadas dominantes, que pra eles funciona bem, pros deputados o SUS funciona bem. Nós temos grandes hospitais, que eu não vou citar o nome, que tem cotas para atender esta elite com dinheiro do sistema público de saúde. Então nós temos no SUS uma seleção, onde ainda existe as oligarquias que se privilegiam da coisa pública (UMGP).

\section{Pauperização}

O que a gente sente? É óbvio que o caso dos meus filhos não é isolado neste tipo de enfermidade, é lógico que alguns dentro de todo o sistema são atendidos, mas na grande maioria, ou a pessoa chega ao ponto de "hiperendividamento" da familia e não resolve o problema porque continua necessitando, ou reza por um milagre, ou morre (UMGP).

Então eu como usuária já reclamei na secretaria de saúde e já dentro de uma reunião que nós estávamos junto com os representantes da usina e com representantes da saúde eu questionei isso aí. Porque eles (Pronto Socorro) negam em dar o atestado alegando que o atestado tem que ser quando vai consultar, mas geralmente não tem o médico pra poder atender o trabalhador nos PSF. Aí esse trabalhador perde o dia e ainda perde a cesta dele, porque o sindicato negociou. E se quiser o atestado tem que pagar. Porque ele não escolhe ficar doente, mas igual, por exemplo, se ele não leva o atestado ele perde, porque a falta injustificada ela perde a cesta que é o benefício que a empresa dá pro trabalhador (UMMP). 


\section{Humilhação Social}

Na verdade, não tem outra palavra eu tive que brigar, porque aí nós tivemos vários meses em processo administrativo pra conseguir estes medicamentos e outras coisas que os bebês precisavam, como não consegui, nós fomos para o judiciário. $O$ judiciário inclusive acatou a liminar, saiu a liminar que era para a entrega das coisas e a prefeitura não foi, o estado também não comtemplou a necessidade principal, porque mandavam frasco, mas não mandava equipo, então mandava o que sobrava lá dentro da secretaria, mandava seringa, mas não mandava leite. Aí eu vi que não dava, fui pro tudo ou nada, pra imprensa, pras redes sociais e só assim conseguimos. Só mesmo desmascarando o processo de negligência, o processo de omissão e um processo até meio sadista por parte do governante, porque ele tem consciência e não tem pressa nenhuma de resolver. Algo até perverso, porque o cara sabe e aí ele vira e fala pra você, pode ficar tranquilo que daqui dois dias eu entrego pra você. E o menino internado, daqui dois dias eu entrego pra você e o menino piorando a situação e eles só passando mentira. E é um processo também de humilhação, ou seja, ele tira a dignidade das pessoas (UMGP).

Eles começam a enrolar pra não atender dizendo que não têm dinheiro em caixa, usaram até a teoria do mal maior dizendo que se atendessem as despesas com meus filhos colocariam em colapso a Secretaria Municipal de Saúde (UMGP).

Você tem que ir pra lá de madrugada pra aguardar a vaga, aí você fica lá o dia todo esperando a vaga. Aí eles vão, por exemplo, te passar que é por ordem de chegada, a vez que eu fui era assim, você ia bem cedinho de madrugada, o que chegasse primeiro, era por ordem de chegada (UMPP).

\section{Anomia}

Sem a participação social o controle social se torna uma peça maligna, porque o controle não é da sociedade é daqueles que participam que é geralmente quem está dentro da máquina, sobretudo da máquina pública (U.MGP).

Nós temos uma cultura de não participação que é transmitida de pai pra filho, e ainda existe o medo das pessoas enfrentarem, você sabe aquele ditado, manda quem pode obedece quem tem juízo. E isso só pode ser vencido com a educação, não essa educação que temos que é tutelada, doutrinária, sobretudo nas universidades federais, onde o governo utiliza instrumentos para manter o que aí está (U.MGP).

Agora nós temos os velhos vícios que é a manutenção de tudo que é hoje, existe uma grande força de manutenção. Existe um outro problema que também é cultural e aí que as pessoas não gostam de falar isso abertamente, porque tem medo de falar disso abertamente, que é das pessoas no país quererem crescer dentro desta regra, vale 
tudo pra crescer, se eu tiver lá eu vou replicar as mesmas coisas. Então o problema da saúde passa pela corrupção (U.MGP).

\section{Gestão casuística}

A exposição pública é a única linguagem de pressão que o poder público conhece hoje. O gestor, o político que ali se coloca à disposição pra poder resolver os problemas da sociedade, na realidade, faz somente administrar a máquina, administrar o problema e não resolver o problema (UMGP).

\section{"Pseudoética” profissional}

Então porque ele não tem uma clínica de atendimento pra poder atender essas gestantes, ele não tem um hospital pra poder operar elas, então ele opera elas que eu sei que ele cobra pra fazer a cirurgia, a cesariana. Inclusive até se sabe assim, o SUS ele opta mais por fazer o parto normal, a pessoa tem que dar ali o parto normal, se caso de última questão a pessoa não der o parto normal, aí ele vai fazer a cesariana, mas é em última hipótese. Então tem caso de mulheres que faz o pré-natal pelo SUS com aquele médico, aí o médico oferece pra ela, quando ele vê que ela tem um pouquinho mais de condição, aí eles paga pelo parto cesariano, ele paga ali pra poder fazer dentro do hospital (UMPP).

E de repente, ele tá ganhando dá mãe particular e tá ganhando pelo SUS. Ele ganha das duas formas, e a mãe também tem condição de ter um parto normal, ele retira essa condição pra ela ganhar dentro do SUS e faz a cesariana. É isso que tá acontecendo aqui. E até então, lembrando melhor também, ele tem a clínica dele particular, atende essas mulheres particular a vida inteira e depois joga essas pacientes pro SUS, pra poder usar o hospital, as enfermeiras do SUS, os material do SUS e não tem nenhum gasto (UMPP).

\section{Fetiche dos números}

Nós temos uma universalização, como diz o ditado, pra inglês ver. Na verdade nós criamos números, você abre não sei quantas UBS (s) no Brasil, quantos postos, quantos médicos você formou, quantos médicos estão empregados, se não tem médicos! Eu trago o Mais Médicos e coloca dentro do sistema, enfim você está colocando números. Você vai vender o seco, sem na verdade mostrar a profundidade do que foi atendido (UMGP). 
ALGUMAS CONSIDERAÇÕES FINAIS 



\title{
Por uma síntese necessária
}

"Onde vivemos:

Coragem é loucura;

Bondade é fraqueza;

Pobreza é preguiça;

Verdade é ameaça;

Mentira é defesa;

Riqueza é poder"

Marco Antonio de Castro Figueiredo

Trazer para o debate acadêmico as racionalidades e intencionalidades que norteiam a atuação de alguns atores sociais no fazer saúde bem como a vivência dos usuários acerca da cotidianidade do SUS não é mero exercício de retórica. Trata-se de uma experiência que consiste em fortalecer a cidadania, lutando contra a desigualdade social.

\begin{abstract}
A cidadania se constitui em um arcabouço de direitos, prerrogativas e deveres que configura um sistema de reciprocidades determinantes da natureza das relações entre os indivíduos entre si e com o Estado. Seu enraizamento na vida coletiva como sentimento, cultura e sistema de referências valorativas torna-se medida fundamental do grau de democratização alcançado por uma dada sociedade. Sua configuração política normativa mais ampla se expressa através de um conjunto de valores morais e regras jurídicas e sociais que sustentam as relações de reciprocidade e de interdependência entre os indivíduos e os diversos grupos sociais na concretude da ação coletiva (Rego, 2008, p. 149).
\end{abstract}

A análise dos depoimentos nos permitiu identificar que o processo de reificação da saúde pode ser considerado determinante, tanto para a desestruturação do Sistema Único de Saúde, como para a perda da subjetividade e cidadania dos indivíduos.

Acreditamos na centralidade da reificação como imperativo ao capital no sentido de manter e ampliar seus padrões de acumulação e dominação que, na prática dos serviços de saúde, tem substituído "trabalho vivo" por "trabalho morto". A consciência reificada transforma a atividade em saúde em ações desconexas, mediadas por motivações particulares, perdidas em um mundo subjetivo sem articulação entre a teoria e a prática, onde os problemas de saúde se apresentam como problemas individuais em um sistema fechado.

Concomitantemente, observa-se a reificação do ser humano, que se apresenta como um objeto físico (incompleto), privado de qualidades humanas, em um cenário de múltiplas 
individualidades, tornando-se diversas coisas, diversos objetos de consumo. Tal conjuntura coarta a percepção e permite que se naturalize esta condição. Desta forma, prevalece na ação em saúde uma relação entre coisas, clientes, leitos, vagas, exames, médicos, remédios, diagnósticos, doenças, recursos, falta de recursos, sistemas de informação, alta tecnologia, baixa tecnologia, quem pode comprar, quem não pode comprar, quem pode usar, quem não pode usar, dinheiro, etc. Os indivíduos e suas necessidades de vida deixam de ser o foco dos serviços de saúde.

A atenção em saúde passa a ser determinada pelo modelo biomédico, centrado na cura de doenças diagnosticadas exclusivamente por parâmetros biológicos e baseado na relação vertical médico paciente, onde os determinantes psicossociais são considerados competências de outras especialidades. Este modelo emblemático é hegemônico pela valorização excessiva da formação técnica especializada, medicalização e prevalência da tecnologia e consumo (E.M. Oliveira et al., 2015).

Em nosso entendimento, frente a reificação da saúde, para reversão do modelo assistencial vigente como objetiva o Ministério da Saúde (1997, p. 8), faz-se necessário, antes, a Ressignificação da Saúde, (re)focalizando os sujeitos no interior das relações sociais reificadas. Como assevera Dâmaso (1989):

Não se trata de melhorar o sistema, mas de transformá-lo estruturalmente, invertendo a lógica do seu funcionamento, introduzindo no planejamento de saúde a categoria das lutas de classes. Não se trata mais de assistir e de integrar os doentes, mas de atuar ao nível das condições sociais de produção das doenças (p. 72).

Outro aspecto a ser considerado no processo de Ressignificação da Saúde é a necessária desnaturalização do sentido de saúde como mercadoria para o seu único sentido possível, o de "premissa existencial humana" (Lefèvre, 1991). Temos para isso, como esfera de ação, a comunidade e a vida cotidiana, onde o modelo biomédico, fragmentado, dicotômico, consumista e hegemônico convive com outros modelos não consumistas, de base coletiva e popular. É neste espaço que acreditamos ser possível romper com os paradigmas atuais e deslocar a hegemonia.

Em outras palavras, as atividades reificadas em saúde podem ser enfrentadas a partir da formulação de estratégias de organização com a comunidade, cuja síntese realizada com os usuários, permite identificar critérios de enfrentamento com base no cotidiano, dentro do processo saúde/doença.

O desenvolvimento do capitalismo reifica as ciências em campos estanques, modificando-as a tal ponto que já não conseguem relacionar-se entre si, de maneira que se 
desenvolvam separadamente e que a evolução de uma não possibilite o avanço da outra. Para um processo de Ressignificação da Saúde faz-se necessário a eliminação das fronteiras especializadas. Assim, a aproximação do setor saúde a outros grupos, movimentos sociais e suas bandeiras de luta apresenta-se indispensável na defesa de transformações societárias profundas e de posicionamentos contrários as relações sociais capitalistas que estão na raiz da determinação social da saúde e da doença, que reproduzem desigualdades sociais e determinam a reificação da saúde. É vital colocar-se ao lado de todas as demais lutas dos trabalhadores e trabalhadoras com vistas à superação da sociedade capitalista, o que pressupõe a defesa intransigente de uma sociedade justa, sem discriminação de gênero, etnia, raça, orientação sexual e sem divisão de classes.

"A saúde é direito de todos e dever do Estado". O direito universal à saúde é uma bandeira do movimento social brasileiro desde os anos 70 . Há que se defender o direito universal aos serviços de saúde. A proposta de exclusividade do SUS para os pobres e do sistema suplementar de planos privados de saúde para ricos reproduz a fragmentação da própria sociedade, negligenciando a principal causa das desigualdades, ou seja, a luta de classes. A compreensão da saúde como premissa existencial humana pode contribuir para legitimar a participação social nos processos produtivos em saúde, diminuindo a influência do complexo médico-empresarial na elaboração e produção das práticas de saúde, fruto das relações sociais reificadas.

Quanto à participação popular, há que se trabalhar sob a perspectiva da conquista da "autonomia" dos sujeitos, a quem se deve dar condições de decidir entre alternativas possíveis, não há que se restringir a participação popular apenas ao instituído, Conselhos municipais e Conferências de Saúde. A participação popular se estende ao cotidiano, à politização e democratização da gestão em saúde, segundo as necessidades do enfrentamento do processo saúde/doença (E.M. Oliveira, 2009; E.M. Oliveira et al., 2015).

Em relação a "autonomia”, Mészáros (2006, p. 244) destaca:

Buscar o remédio na "autonomia" é estar no caminho errado. Nossos problemas não resultam de uma falta de "autonomia", e sim, ao contrário, de uma estrutura social - um modo de produção - que impões ao homem um culto dela, isolando-o dos outros homens. A pergunta vital, que deve ser formulada sobre a autonomia, é: o que se pode fazer com ela? Se apenas a "temos", como uma "faculdade psicológica", um aspecto da "estrutura do caráter", ou como um direito oco limitado à esfera da "privacidade", para todas as razões práticas isso equivale à mesma coisa que simplesmente não a ter.

Ser capaz de fazer alguma coisa por meio da 'autonomia' envolve necessariamente 'o outro'. Em consequência, a única forma de 'autonomia' que vale a pena examinar é a 'autonomia' não-autônoma. Em outras palavras: a 'autonomia' humanamente significativa não é, na realidade, diferente da reciprocidade social, no curso do qual os indivíduos envolvidos uns 
com os outros adaptam-se mutualmente às condições determinadas de intercâmbio e, ao mesmo tempo, conservam o poder de iniciativa. Se tal reciprocidade existe ou não, depende do caráter da estrutura social dada. É, portanto, muito enganoso reduzir esse problema - que envolve muitos fatores econômicos, políticos, sociais, educacionais etc. - ao slogan psicológico oco, da palavra 'autonomia' obscuramente sugerida.

Claramente o culto do indivíduo - ele mesmo um produto da alienação - não pode oferecer nenhum antidoto contra a alienação e reificação. Só pode ampliar o abismo que separa o homem, no capitalismo, de sua interação social [itálicos do autor].

Pensar em ações de fortalecimento do poder popular implica a incorporação dos espaços de lutas já existentes e a construção de outros espaços coletivos em um cenário onde os sujeitos possam construir a própria identidade a partir de suas necessidades e desejos.

Neste sentido, a conquista de um conhecimento crítico é essencial para a liberdade e a afirmação de um projeto político das classes subordinadas ou, em outras palavras, para a construção de uma vontade coletiva com responsabilidade social. As lutas desenvolvidas na sociedade civil e na sua cotidianidade precisam ser problematizadas dentro das contradições da sociedade de classes com vistas à emancipação humana, devendo materializar-se através da efetiva participação das classes subordinadas na condução das políticas sociais públicas. Somente desta maneira os conselhos poderão deixar de se constituir em mecanismos de legitimação do poder dominante e cooptação dos movimentos sociais, que em vez de controlar passam a ser controlados (Bravo \& Correia, 2012).

Há que se considerar a contribuição indispensável das universidades neste processo, socializando o conhecimento que hoje não extrapola os muros do meio acadêmico. Repensar a relação com o conhecimento enquanto instrumento de poder e luta que deve estar comprometido com a construção de uma nova ordem societária, que tenha como primazia a dignidade da vida humana e a emancipação do homem, é uma necessidade essencial para um processo de transformação e ressignificação do papel social da universidade. O conhecimento construído e socializado deve estar entrelaçado à vida cotidiana, à dor humana, às lutas de transformação social em favor daqueles que constroem a riqueza material do mundo e que são excluídos do acesso a ela.

Não se trata de privilegiar o 'prático' relativamente ao teórico, trata-se de dar um embasamento concreto à própria teoria [itálicos nossos] (Dowbor, 2007, p. 81).

Através dos diversos espaços de diálogo com a população é que se pode conhecer e reconhecer as demandas reais por saúde, sentidas e vividas no cotidiano das relações com os serviços de saúde. Dowbor (2007) coloca que ações como: mobilizar as capacidades científicas locais em torno da resolução dos problemas básicos enfrentados pela população, formando profissionais interessados e comprometidos com a realidade vivenciada 
cotidianamente pelas pessoas; criar instrumentos de representação por bairro e assegurar espaços de reuniões e debates que permitam discutir a atribuição de verbas, definir as prioridades, debater as próprias formas de participação, são alicerces essenciais para a construção do efetivo exercício do controle social e da cidadania.

O desenvolvimento desse estudo oportuniza a elaboração de programas de extensão universitária, investindo na formação de profissionais e novos pesquisadores na área, com uma abordagem multivariada advinda da relação com a comunidade, onde a intencionalidade permite uma resposta às necessidades de vida determinada pela síntese da ciência com o conhecimento informal. 


\section{REFERÊNCIAS $^{38}$}

${ }^{38}$ Universidade de São Paulo. Sistema Integrado de Bibliotecas. (2009). Diretrizes para apresentação de dissertações e teses da USP: Documento eletrônico e impresso Parte II (APA). 2. ed. São Paulo: SIBi/USP. 

Alves, A. R. C. (2010). O conceito de hegemonia: De Gramsci a Laclau e Mouffe. Lua Nova: Revista de Cultura e Política, (80), 71-96.

Althusser, L. (1980). Ideologia e aparelhos ideológicos do Estado (3a ed.). Lisboa, Portugal: Presença.

Antunes, A., \& Mathia, M. (2014). Cobertura Universal de Saúde, a nova aposta do capital. Recuperado de http://www.brasildefato.com.br/node/30769

Antunes, R. L. C. (2009). Os sentidos do trabalho: Ensaio sobre a afirmação e a negação do trabalho (2a ed.). São Paulo, SP: Boitempo.

Araújo, D. V., Lima, V. C., \& Ferraz, M. B. (2007). Análise de impacto do stent farmacológico no orçamento do Sistema Único de Saúde. Arquivos Brasileiros de Cardiologia, 88, 458-463.

Assmann, H. (1989). A idolatria do mercado: De como o mercado nos "revela" a verdade e a liberdade. In H. Assmann \& F. J. Hinkelammert, A idolatria do mercado: Ensaio sobre economia e teologia (pp. 236-249). São Paulo, SP: Vozes.

Associação Paulista de Medicina. (2013). Um terço dos usuários de planos de saúde recorre ao SUS ou paga consulta. Recuperado de http://www.apm.org.br/noticiasconteudo. $\operatorname{aspx}$ ?id=9835

Bakhtin, M. (2006). Marxismo e filosofia da linguagem (12a ed.). São Paulo, SP: Hucitec.

Baptista, T. W. F. (2005). O direito à saúde no Brasil: Sobre como chegamos ao sistema único de saúde e o que esperamos dele. In Escola Politécnica de Saúde Joaquim Venâncio (Org.), Textos de apoio em políticas de saúde (pp. 11-41). Rio de Janeiro, RJ: Editora Fiocruz.

Baptista, T. W. F., Machado, C. V., \& Lima, L. D. (2009). Responsabilidade do Estado e direito à saúde no Brasil: Um balanço da atuação dos Poderes. Ciência \& Saúde Coletiva, $14,829-839$.

Barroso, L. R. (s.d.). Da falta de efetividade à judicialização excessiva: Direito à saúde, fornecimento gratuito de medicamentos e parâmetros para a atuação judicial. Recuperado de http://www.conjur.com.br/dl/estudobarroso.pdf 
Barthes, R. (1991). Essais critiques. Paris, France: Seuil. Recuperado de http://www.aelib.org.ua/texts/barthes_essais_critiques_fr.htm

Baudrillard, J. (1991). Simulacro e simulação (M. J. C. Pereira, Trad.). Lisboa, Portugal: Relógio D’Água.

Baudrillard, J. (2011). A sociedade de consumo (A. Mourão, Trad.). Lisboa, Portugal: Edições 70.

Bauman, Z. (1997). Ética pós-moderna (J. R. Costa, Trad.). São Paulo, SP: Paulus.

Bauman, Z. (2008a). A sociedade individualizada: Vidas contadas e histórias vividas (J. Gradei, Trad.). Rio de Janeiro, RJ: Jorge Zahar.

Bauman, Z. (2008b). Vida para consumo: A transformação das pessoas em mercadorias (C. A. Medeiros, Trad.). Rio de Janeiro, RJ: Jorge Zahar.

Bauman, Z. (2010). Legisladores e intérpretes: Sobre modernidade, pós-modernidade e intelectuais (R. Aguiar, Trad.). Rio de Janeiro, RJ: Jorge Zahar.

Behring, E. R. (2008). Brasil em contra-reforma: Desestruturação do Estado e perda de direitos (2a ed.). São Paulo, SP: Cortez.

Behring, E. R., \& Boschetti, I. (2009). Politica social: Fundamentos e história (6a ed., Vol. 2). São Paulo, SP: Cortez.

Bertolli Filho, C. (2002). História da saúde pública no Brasil (4a ed.). São Paulo, SP: Ática.

Bicalho, M. S. (2003). Conselheiros de saúde construindo o controle social do SUS. Psicologia em Revista, 10, 149-154.

Bisol, J. (2009). Judicialização desestruturante: Reveses de uma cultura jurídica obsoleta. In A. B. Costa, J. G. Sousa Junior, M. C. Delduque, M. S. C. Oliveira, \& S. G. Dallari (Orgs.), O direito achado na rua: Introdução crítica ao direito à saúde (pp. 327-331). Brasília, DF: CEAD/UnB.

Bispo Júnior, J. P., \& Sampaio, J. J. C. (2008). Participação social em saúde em áreas rurais do Nordeste do Brasil. Revista Panamericana de Salud Pública, 23, 403-409. 
Bispo Júnior, J. P., Messias, K. L. M., \& Sampaio, J. J. C. (2006). Exercício do controle social em municípios de pequeno porte: O caso de Lafayete Coutinho (BA). Revista Baiana de Saúde Pública, 30, 248-260.

Bobbio, N., Matteucci, N., \& Pasquino, G. (1998). Dicionário de política (C. C. Varriale, G. L. Mônaco, J. Ferreira, L. G. P. Cacais, \& R. Dini, Trads., 11a ed., Vols. 1-2). Brasília, DF: Editora UNB.

Borba, J., \& Lüchmann, L. H. H. (2010). A representação política nos Conselhos Gestores de Políticas Públicas. Revista Brasileira de Gestão Urbana, 2, 229-246.

Borlini, L. M. (2010). Há pedras no meio do caminho do SUS: Os impactos do neoliberalismo na saúde do Brasil. Textos \& Contextos, 9, 321-333.

Bottomore, T. (Ed.). (2001). Dicionário do pensamento marxista (W. Dutra, Trad.). Rio de Janeiro, RJ: Jorge Zahar.

Bravo, M. I. S. (2006). Política de saúde no Brasil. In A. E. Mota, L. Gomes, M. I. S. Bravo, M. Teixeira, R. M. G. Marsiglia, \& Uchôa, R. Serviço social e saúde: Formação e trabalho profissional. Recuperado de http://www.saude.mt.gov.br/arquivo/2163

Bravo, M. I. S., \& Correia, M. V. C. (2012). Desafios do controle social na atualidade. Serviço Social \& Sociedade, (109), 126-150.

Brito, D. F., Miranda, D. S. M., Ferreira, S. I. T., Campos, S. A. G., \& Nunes, D. V. O. (2011). A "universalização excludente" da política de Saúde e sua Interface no campo dos direitos sociais. Trabalho apresentado no Décimo Quinto Encontro Latino Americano de Iniciação Científica e Décimo Primeiro Encontro Latino Americano de PósGraduação. Universidade do Vale do Paraíba. Recuperado de http://www.inicepg. univap.br/cd/INIC_2011/anais/arquivos/0073_0864_01.pdf

Camargo Junior, K. R. (2007). As armadilhas da "concepção positiva de saúde". Physis: Revista de Saúde Coletiva, 17, 63-76.

Campos, F. E., Aguiar, R. A. T., \& Oliveira, V., B. (2002). O desafio da expansão do Programa de Saúde da Família nas grandes capitais brasileiras. Physis: Revista de Saúde Coletiva, 12(1), 47-58.

Campos Neto, O. H., Acurcio, F. A., Machado, M. A. A., Ferré, F., Barbosa, F. L. V., Cherchiglia, M. L., \& Andrade, E. I. G. (2012). Médicos, advogados e indústria 
farmacêutica na judicialização da saúde em Minas Gerais, Brasil. Revista de Saúde Pública, 46, 784-790.

Capra, F. (1982). O ponto de mutação: A ciência, a sociedade e a cultura emergente (A. Cabral, Trad.). São Paulo, SP: Cultrix.

Carvalhosa, M. (2009). Comentários à lei de sociedades anônimas (3a ed., Vol. 4, Tomo II) São Paulo, SP: Saraiva.

Chaui, M. (1992). Público, privado, despotismo. In A. Novaes, Ética (pp. 345-390). São Paulo, SP: Companhia das Letras.

Chaui, M. S. (2000a). Cultura e democracia: O discurso competente e outras falas. São Paulo, SP: Cortez.

Chaui, M. (2000b). Convite à Filosofia. São Paulo, SP: Ática.

Chaui, M. (2001). Brasil: mito fundador e sociedade autoritária. São Paulo, SP: Perseu Abramo, 2001.

Chieffi, A. L., \& Barata, R. C. B. (2010). Ações judiciais: Estratégia da indústria farmacêutica para introdução de novos medicamentos. Revista de Saúde Pública, 44, 421-429.

Cohn, A. (2002). Mudanças econômicas e políticas de saúde no Brasil. In A. C. Laurell (Org.), Estado e políticas sociais no neoliberalismo (3a ed., pp. 225-244). São Paulo, SP: Cortez.

Cohn, A. (2005). A saúde na previdência social e na seguridade social: Antigos estigmas e novos desafios. In A. Cohn \& P. E. M. Elias. Saúde no Brasil: Políticas e organizações de serviços (6a ed., pp. 13-57). São Paulo, SP: Cortez/CEDEC.

Comisión Económica para América Latina y el Caribe. (2000). Equidad, desarrollo y ciudadanía. Mexico, DF: CEPAL Naciones Unidas. Recuperado de http://repositorio. cepal.org /bitstream/handle/11362/2686/S2006536_es.pdf?sequence=2

Conselho Nacional de Secretários de Saúde. (2011a). Sistema Único de Saúde (Coleção para Entender a Gestão do SUS, Vol. 1). Brasília, DF: CONASS. 
Conselho Nacional de Secretários de Saúde. (2011b). Legislação estruturante do SUS (Coleção para Entender a Gestão do SUS, Vol. 13). Brasília, DF: CONASS.

Conselho Nacional de Secretários de Saúde. (2011c). A gestão administrativa e financeira no SUS (Coleção para Entender a Gestão do SUS, Vol. 8). Brasília, DF: CONASS.

Constituição da República Federativa do Brasil. (1988). (Série textos básicos n. 67. 35a ed., Edições Câmara). Brasília, DF: Câmara dos Deputados. Recuperado de https://www.google.com.br/?gws_rd=ssl\#q=ISBN+978-85-736-5935-1

Cordeiro, H. A. (2001). Descentralização, universalidade e equidade nas reformas da saúde. Ciência \& Saúde Coletiva, 6, 319-328.

Cordeiro, H. A., Conill, E. M., Santos, I. S., \& Bressan, A. I. (2010). Por uma redução nas desigualdades em saúde no Brasil: Qualidade e regulação num sistema com utilização combinada e desigual. In N. R. Santos \& P. D. C. Amarante (Orgs.), Gestão pública e relação público privado na saúde (pp. 129-151). Rio de Janeiro, RJ: Cebes.

Correia, M. V. C. (2006). Controle Social na Saúde. In A. E. Mota, L. Gomes, M. I. S. Bravo, M. Teixeira, R. M. G. Marsiglia, \& Uchôa, R. Serviço social e saúde: Formação e trabalho profissional. Recuperado de http://www.ceap-rs.org.br/wp-content/uploads /2014/02/ Controle-social-na-saude.pdf

Correia, M. V. C. (2008). Controle Social. In I. B. Pereira \& J. C. F. Lima (Orgs.), Dicionário da educação profissional em saúde (2a ed., pp. 104-110). Rio de Janeiro, RJ: EPSJV.

Costa, A. M., Bahia, L., \& Scheffer, M. (2013). Onde foi parar o sonho do SUS? Le Monde Diplomatique Brasil. Recuperado de http://www.diplomatique.org.br/artigo.php?id=1395

Costa, N. R. (1985). Lutas urbanas e controle sanitário: Origens das políticas de saúde no Brasil. Petrópolis, RJ: Vozes.

Coutinho, C. N. (2007). Gramsci: Um estudo sobre seu pensamento político. Rio de Janeiro, RJ: Civilização Brasileira.

Crocco, F. L. T. (2009). Georg Lukács e a reificação: Teoria da constituição da realidade social. Kinesis, 1(2), 49-63.

Dalari, D. A. (1998a). Elementos da teoria geral do estado (2a ed.). São Paulo, SP: Saraiva. 
Dalari, D. A. (1998b). Direitos humanos e cidadania. São Paulo, SP: Moderna.

Dâmaso, R. (1989). Saber e práxis na reforma sanitária: Avaliação da prática científica no movimento sanitário. In S. F. Teixeira (Org.), Reforma sanitária: Em busca de uma teoria (pp. 61-90). São Paulo, SP: Cortez.

Debord, G. (2003). A sociedade do espetáculo: Comentários sobre a sociedade do espetáculo (E. S. Abreu, Trad.). Rio de Janeiro, RJ: Contraponto.

Demo, P. (1995). Metodologia científica em ciências sociais (3a ed.). São Paulo, SP: Atlas.

DeNavas-Walt, C., Proctor, B. D., \& Smith, J. C. (2010). Income, poverty, and health insurance coverage in the United States: 2009. Washington, DC: U.S. Government Printing Office. Recuperado de http://www.census.gov/prod/2010pubs/p60-238.pdf

DeNavas-Walt, C., Proctor, B. D., \& Smith, J. C. (2011). Income, poverty, and health insurance coverage in the United States: 2010. Washington, DC: U.S. Government Printing Office. Recuperado de http://www.census.gov/prod/2011pubs/p60-239.pdf

Diretoria Nacional do Cebes. (2014). Em defesa do direito universal à saúde: Saúde é direito e não negócio. Saúde em Debate, 38, 194-199.

Dowbor, L. (2007). Educação e apropriação da realidade local. Estudos Avançados, 21, 75-90.

Duarte, J., \& Barros, A. (Orgs.). (2006). Métodos e técnicas de pesquisa em comunicação (2a ed.). São Paulo, SP: Atlas.

Elias, P. E. (s.d.). Políticas de saúde: Reforma ou contra-reforma: Algumas reflexões sobre as políticas de saúde no Brasil. Recuperado de http://www.gesan.ndsr.org/ docmanualespecializacao05PoliticasdeSaude.pdf

Escorel, S. (2008). Equidade em saúde. In I. B. Pereira \& J. C. F. Lima (Orgs.), Dicionário da educação profissional em saúde (2a ed., pp. 202-210). Rio de Janeiro, RJ: EPSJV.

Escorel, S., Nascimento, D. R., \& Edler, F. C. (2005). As origens da reforma sanitária e do SUS. In N. T. Lima, S. Gerschman, F. C. Edler, \& J. M. Suárez (Orgs.). Saúde e democracia: História e perspectivas do SUS (pp. 59-81). Rio de Janeiro, RJ: Fiocruz. 
Faleiros, V. P. (2000). Natureza e desenvolvimento das políticas sociais no Brasil. In Capacitação em serviço social e política social: Política social (Mod. 3). Brasília, DF: CEAD/CFESS/ABEPSS/UnB, 2000.

Ferraz, O. L. M., \& Vieira, F. S. (2009). Direito à saúde, recursos escassos e equidade: Os riscos da interpretação judicial dominante. Dados, 52, 223-251.

Ferreira, A. A. (2006). Participação, sociedade civil e a capacidade de influenciar políticas sociais: $O$ caso do conselho municipal de educação da Serra (Dissertação de mestrado). Recuperado de http://web3.ufes.br/ppgps/sites/web3.ufes.br.ppgps/files/Andreza $\% 20$ A $\% 20$ Ferreira.pdf

Figueiredo, M. A. C. (1989). O trabalho alienado e o psicólogo do trabalho: Algumas questões sobre o papel do psicólogo no controle da produção capitalista. São Paulo, SP: EDICON.

Figueiredo, M. A. C. (1998). Escalas afetivo-cognitivas de atitude. Construção, validação e interpretação dos resultados. In G. Romanelli \& Z. M. M. Biasoli-Alves (Orgs.), Diálogos metodológicos sobre prática da pesquisa (pp. 51-70). Ribeirão Preto, SP: Legis-Summa.

Figueiredo, M. A. C. (2003). Avaliação de um programa de orientação e suporte psicossocial ao cuidado doméstico de pessoas que vivem com HIV/AIDS: Um estudo com base na tríade paciente/profissional/familiar (Relatório de Pesquisa). Ribeirão Preto, SP: CNPq.

Finkelman, J. (Org.). (2002). Caminhos da saúde pública no Brasil. Rio de Janeiro, RJ: Editora Fiocruz.

Fiori, J. L. (1990). Transição terminada: Crise superada? Novos Estudos CEBRAP, (28), 137151.

Fiori, J. L. (1995). Sonhos prussianos, crises brasileiras: Leitura política de uma industrialização tardia. In Em busca do dissenso perdido: Ensaios críticos sobre a festejada crise do Estado (pp. 57-84). Rio de Janeiro, RJ: INsight.

Fleury, S. (2009). Reforma sanitária brasileira: Dilemas entre o instituinte e o instituído. Ciência \& Saúde Coletiva, 14, 743-752.

Fleury, S. (2012). Judicialização pode salvar o SUS. Saúde em Debate, 36, 159-162. 
Fraser, N. (2002). A justiça social na globalização: Redistribuição, reconhecimento e participação Revista Crítica de Ciências Sociais, 63, 7-20.

Gerschman, S., \& Santos, M. A. B. (2006). O Sistema Único de Saúde como desdobramento das políticas de saúde do século XX. Revista Brasileira de Ciências Sociais, 21(61), 177190.

Giddens, A. (1991). As consequências da modernidade (R. Fiker, Trad.). São Paulo, SP: Editora UNESP.

Giddens, A. (2002). Modernidade e identidade (P. Dentzien, Trad.). Rio de Janeiro, RJ: Jorge Zahar.

Giddens, A., \& Pierson, C. (Orgs.). (2000). Conversas com Anthony Giddens: O sentido da modernidade (L. A. Monjardim, Trad.). Rio de Janeiro, RJ: Editora FGV.

Giovanella, L., \& Fleury, S. (1996). Universalidade da atenção à saúde: Acesso como categoria de análise. In C. Eibenschutz (Org.), Política de saúde: O público e o privado (pp. 177-198). Rio de Janeiro, RJ: Editora Fiocruz.

Gomes, F. F. C., Cherchiglia, M. L., Machado, C. D., Santos, V. C., Acurcio, F. A., \& Andrade, E. I. G. (2014). Acesso aos procedimentos de média e alta complexidade no Sistema Único de Saúde: Uma questão de judicialização. Cadernos de Saúde Pública, 30, 31-43.

Gramsci, A. (2001). Cadernos do cárcere (C. N. Coutinho, Trad., 2a ed., Vol. 2.). Rio de Janeiro, RJ: Civilização Brasileira.

Gramsci, A. (2011). Cartas do cárcere. Recuperado de http://estaleiroeditora.blogaliza. org/files/2011/08/cartas_do_carcere_gramsci_pant.pdf

Gruppi, L. O conceito de hegemonia em Gramsci (C. N. Coutinho, Trad.). Rio de Janeiro, RJ: Graal.

Guizardi, F. L., Pinheiro, R., Mattos, R. A., Santana, A. D., Matta, G., \& Gomes, M. C. P. A. (2004). Participação da comunidade em espaços públicos de saúde: Uma análise das conferências nacionais de saúde. Physis: Revista de Saúde Coletiva, 14(1), 15-39. 
Hinkelammert, F. J. (1989). Ensaio temático: O significado dos critérios de decisão econômica. In H. Assmam \& F. J. Hinkelammert, A idolatria do mercado: Ensaio sobre economia e teologia (pp. 178-197). São Paulo, SP: Vozes.

Hahn, E., \& Kosing, A. (1983). A filosofia marxista leninista: Curso básico. Lisboa, Portugal: Edições Avante!

Horton, J. (2004). Anomia e Alienação: Um Problema na Ideologia da Sociologia. In M. M. Foracchi \& J. S. Martins, Sociologia e Sociedade: Leituras de introdução à Sociologia (pp. 77-89). Rio de Janeiro, RJ: Livros Técnicos e Científicos Editora S. A.

Iamamoto, M. V. (1999). O trabalho do assistente social frente às mudanças do padrão de acumulação e de regulação social. In Universidade de Brasília, Capacitação em serviço social e política social: Módulo 01: Crise contemporânea, questão social e serviço social (pp. 111-128). Brasília, DF: CEAD.

Iamamoto, M. V., \& Carvalho, R. (2006). Relações sociais e serviço social no Brasil: Esboço de uma interpretação histórico-metodológica (19a ed.). São Paulo, SP: Cortez.

Ianni, O. (2001). Teorias da globalização (9a ed.). Rio de Janeiro, RJ: Civilização Brasileira.

Ibanhes, L. C., Heimann, L. S., Junqueira, V., Boaretto, R. C., Pessoto, U. C., Cortizo, C. T., Telesi, E., Jr. (2007). Governança e regulação na saúde: Desafios para a gestão na Região Metropolitana de São Paulo, Brasil. Cadernos de Saúde Pública, 23, 575-584.

Instituto Brasileiro de Geografia e Estatística. (2010a). Censo Demográfico 2010. Rio de Janeiro, RJ: IBGE.

Instituto Brasileiro de Geografia e Estatística. (2010b). Pesquisa Nacional por Amostra de Domicílios: Acesso e utilização dos serviços, condições de saúde e fatores de risco e proteção à saúde 2008. Rio de Janeiro, RJ: IBGE.

Instituto Brasileiro de Geografia e Estatística. (2011). Indicadores Sociais Municipais 2010: Incidência de pobreza é maior nos municípios de porte médio. Rio de Janeiro, RJ: IBGE.

Instituto Brasileiro de Geografia e Estatística. (2014). Estimativas da população residente no brasil e unidades da federação com data de referência em $1^{\circ}$ de julho de 2014 . Rio de Janeiro, RJ: IBGE. 
Jappe, A. (2014). Alienação, reificação e fetichismo da mercadoria. Limiar, 1(2), 1-16.

Lavalle, A. G., Houtzager, P. P., \& Castello, G. (2006). Representação política e organizações civis: Novas instâncias de mediação e os desafios da legitimidade. Revista Brasileira de Ciências Sociais, 21, 43-66.

Lefèvre, F. (1983). A função simbólica dos medicamentos. Revista de Saúde Pública, 17, 500-503.

Lefèvre, F. (1987). A oferta e a procura de saúde através de medicamento: Proposta de um campo de pesquisa. Revista de Saúde Pública, 21, 64-67.

Lefèvre, F. (1991). O medicamento como mercadoria simbólica. São Paulo, SP: Cortez.

Lefèvre, F. (1995). Saúde, mídia e reificação. In A. M. R. Pitta (Org.), Saúde e comunicação: Visibilidades e silêncios (pp. 138-147). São Paulo, SP: Hucitec.

Lefèvre, F. (1997). Saúde, este obscuro objeto de desejo. Saúde e Sociedade, 6(1), 3-9.

Lima, J. C. (2001). Representatividade e participação das bases na categoria dos usuários de um Conselho Municipal de Saúde. Saúde em Debate, 25, 29-39.

Londoño, J. L., \& Frenk, J. (1997). Pluralismo estructurado: Hacia un modelo innovador para la reforma de los sistemas de salud en América Latina (Documento de Trabajo 353). BID. Recuperado de http://www.iadb.org/es/investigacion-y-datos/detalles-depublicacion,3169.html?pub_id=WP-353

Löwy, M. (1991). Ideologias e ciência social: Elementos para uma análise marxista (7a ed.). São Paulo, SP: Pontifica Universidade Católica de São Paulo.

Lüdke, M., \& André, M. E. D. A. (1986). Pesquisa em educação: Abordagens qualitativas. São Paulo, SP: EPU.

Lukács, G. (1974). História e consciência de classe: Estudos de dialética marxista (T. Costa, Trad.). Porto, Portugal: Publicações Escorpião.

Luz, M. T. (1991). Notas sobre as políticas de saúde no Brasil de "Transição Democrática": Anos 80. Physis: Revista de Saúde Coletiva, 1, 77-96. 
Machado, M. A. A., Acurcio, F. A., Brandão, C. M. R., Faleiros, D. R., Guerra, A. A., Jr., Cherchiglia, M. L., \& Andrade, E. I. G. (2011). Judicialização do acesso a medicamentos no Estado de Minas Gerais, Brasil. Revista de Saúde Pública, 45, 590-598.

Maciel, C. A. B. (2010). Políticas Públicas e Controle Social: Encontros e desencontros da experiência brasileira. Revista Intercâmbio dos Congressos de Humanidades, 1, 1-18.

Malachias, I., Leles, F. A. G., \& Pinto, M. A. S. (2010). Plano Diretor de Regionalização da Saúde de Minas Gerais. Belo Horizonte, MG: Secretaria de Estado de Saúde de Minas Gerais.

Manzini Covre, M. L. (2002). O que é cidadania (3a ed.). São Paulo, SP: Brasiliense.

Martins, L. M. (s.d.). As aparências enganam: divergências entre o materialismo histórico dialético $e$ as abordagens qualitativas de pesquisa. Recuperado de http://www.histedbr.unir.br/downloads/3786_as+aparencias+enganam+_+divergencias + entre+o+mhd+e+as+abordagens+qualitativas.pdf

Martins, M. F. (2008). Sociedade civil e terceiro setor: Apropriações indébitas do legado teórico-político de Gramsci. Revista de Filosofia Aurora, 20, 75-100.

Marx, K. (1996). O capital: Crítica da economia política: O processo de produção do capital (Vol. 1, Tomo 1). São Paulo, SP: Nova Cultural.

Marx, K., \& Engels, F. (1998). A ideologia alemã (L. C. C. Costa, Trad.). São Paulo, SP: Martins Fontes.

Marx, K., \& Engels, F. (2001). Manifesto do partido comunista (S. T. B. Cassal, Trad.). Porto Alegre, RS: L\&PM.

Marx, K., \& Engels, F. (2007). A ideologia alemã: Crítica da mais recente filosofia alemã em seus representantes Feuerbach, B. Bauer e Stirner, e do socialismo alemão em seus diferentes profetas (1845-1846) (R. Enderle, N. Schneider, \& L. C. Martorano, Trads.). São Paulo, SP: Boitempo.

Matta, G. C. (2008). Universalidade. In I. B. Pereira \& J. C. F. Lima (Orgs.), Dicionário da educação profissional em saúde (2a. ed., pp. 465-469). Rio de Janeiro, RJ: EPSJV. 
Mayer, A. L. M. (2006). Reificação e barbárie: Crítica às relações sociais capitalistas (Tese de doutorado, Universidade Federal do Rio de Janeiro). Recuperado de http://www.dominiopublico.gov.br/download/texto/cp021759.pdf

McKinsey Global Institute. (2007). Accounting for the cost of health care in the United States. Recuperado de http://www.mckinsey.com/insights/health_systems_and_services/ accounting_for_the_cost_of_health_care_in_the_united_states

McKinsey Global Institute. (2008). Accounting for the cost of US health care: A new look at why Americans spend more. Recuperado de http://www.mckinsey.com/insights/health _systems_and_services/accounting_for_the_cost_of_us_health_care

Meireles, M. M. (2001). Anomia. Rio de Janeiro, RJ: Casa do Psicólogo.

Mendes, E. V. (1994). As políticas de saúde no Brasil nos anos 80: A conformação da reforma sanitária e a construção da hegemonia do projeto neoliberal. In E. V. Mendes (Org.), Distrito sanitário: O processo social de mudança das práticas sanitárias do Sistema Único de Saúde (2a ed., pp. 19-91). São Paulo, SP: Hucitec.

Mendes, E. V. (1999). O Sistema Único de Saúde: Um processo social em construção. In E. V. Mendes, Uma agenda para saúde (2a ed., pp. 57-98). São Paulo, SP: Hucitec.

Mendes, E. V. (2001). Os grandes dilemas do SUS: Tomo I. Salvador, BA: Casa da Qualidade.

Mendes, E. V. (2013). 25 anos do Sistema Único de Saúde: Resultados e desafios. Estudos Avançados, 27(78), 27-34.

Menicucci, T. M. G. (2010). A reforma sanitária brasileira e as relações entre o público e o privado. In N. R. Santos e P. D. C. Amarante (Orgs.), Gestão Pública e Relação Público Privado na Saúde (pp. 180-197). Rio de Janeiro, RJ: Cebes.

Messeder, A. M., Osorio-de-Castro, C. G. S., \& Luiza, V. L. (2005). Mandados judiciais como ferramenta para garantia do acesso a medicamentos no setor público: A experiência do Estado do Rio de Janeiro, Brasil. Cadernos de Saúde Pública, 21, 525-534.

Mészáros, I. (2006). A teoria da alienação em Marx (I. Tavares, Trad.). São Paulo, SP: Boitempo. 
Mészáros, I. (2011). Para além do capital: Rumo a uma teoria da transição (P. C. Castanheira \& S. Lessa, Trad.). São Paulo, SP: Boitempo.

Minayo, M. C. S. (1998). O desafio do conhecimento: Pesquisa qualitativa em saúde (5a ed.). São Paulo, SP: Hucitec.

Ministério da Saúde. (1986). Relatório final da Oitava Conferência Nacional de Saúde. Brasília, DF: Ministério da Saúde. Recuperado de http://conselho.saude.gov.br/ biblioteca/relatorios/relatorio_8.pdf

Ministério da Saúde. (1992). Relatório final: Municipalização é o caminho da Nona Conferência Nacional de Saúde. Brasília, DF: Ministério da Saúde. Recuperado de http://conselho.saude.gov.br /biblioteca/Relatorios/relatorio_9.pdf

Ministério da Saúde. Conselho Nacional de Saúde. (2003). Resolução n. ${ }^{\circ}$ 333, de 4 de novembro de 2003. Brasília, DF: Ministério da Saúde.

Ministério da Saúde. Coordenação de Projetos de Promoção de Saúde. (2001). O SUS e o controle social: Guia de referência para conselheiros municipais. Brasília, DF: Ministério da Saúde.

Ministério da Saúde. Secretaria de Assistência à Saúde. Coordenação de Saúde da Comunidade. (1997). Saúde da família: Uma estratégia para a reorientação do modelo assistencial. Brasília, DF: Ministério da Saúde.

Ministério da Saúde. Secretaria de Atenção à Saúde. Departamento de Atenção Básica. (2006a). Política nacional de atenção básica. Brasília, DF: Ministério da Saúde.

Ministério da Saúde. Secretaria de Gestão de Investimentos em Saúde. Departamento de Gerenciamento de Investimentos. (2002). Guia do conselheiro: Curso de capacitação de conselheiros estaduais e municipais de saúde. Brasília, DF: Ministério da Saúde.

Ministério da Saúde. Secretaria de Gestão Estratégica e Participativa. (2006b). A construção do SUS: Histórias da reforma sanitária e do processo participativo. Brasília, DF: Ministério da Saúde.

Ministério da Saúde. Secretaria Nacional de Assistência à Saúde. (1990). ABC do SUS: Doutrinas e princípios. Brasília, DF: Ministério da Saúde. 
Montaño, C. (2010). Terceiro setor e questão social: Crítica ao padrão emergente de intervenção social (6a ed.). São Paulo, SP: Cortez.

Musgrove, P. (1996). Public and private roles in health: Theory and financing patterns. Washington, DC: World Bank.

Nascimento, A. (2007). Propaganda de medicamentos: Como conciliar uso racional e a permanente necessidade de expandir mercado? Trabalho, Educação e Saúde, 5, 189-250.

Netto, J. P. (1981). Capitalismo e reificação. São Paulo, SP: Livraria Editora Ciências Humanas.

Nogueira, R. P. (2010). O desenvolvimento federativo do sus e as novas modalidades institucionais de gerência das unidades assistenciais. In N. R. Santos e P. D. C. Amarante (Orgs.), Gestão Pública e Relação Público Privado na Saúde (pp. 24-47). Rio de Janeiro, RJ: Cebes.

Noronha, J. C. (2013). Cobertura universal de saúde: Como misturar conceitos, confundir objetivos, abandonar princípios. Cadernos de Saúde Pública, 29, 847-849.

Noronha, J. C., \& Ugá, M. A. D. (1995). O sistema de saúde dos Estados Unidos. In P. M. Buss \& M. E. Labra (Orgs.), Sistemas de saúde: Continuidades e mudanças (pp. 177218). Rio de Janeiro, RJ: Editora Fiocruz.

Noronha, J. C., \& Soares, L. T. (2001). A política de saúde no Brasil nos anos 90. Ciência \& Saúde Coletiva, 6, 445-450.

O'Hara, B., \& Day, J. C. (2014, September 16). Married with health insurance coverage. U. S. Census Bureau. Recuperado de http://blogs.census.gov/2014/09/16/married-withhealth-insurance/

Oliveira, E. M. (2009). Processos de apropriação da prática na construção do cuidado em saúde, sob a perspectiva de usuários do Programa de Saúde da Família Rural de Sacramento/MG (Dissertação de Mestrado). Recuperado de http://www.teses.usp.br/ teses/disponiveis/59/59137/tde-13062013-110812/pt-br.php

Oliveira, E. M., Felipe, E. A., Santana, H. S., Rocha, I. H., Magnabosco, P., \& Figueiredo, M. A. C. (2015). Determinantes sócio-históricos do cuidado na Estratégia Saúde da Família: A perspectiva de usuários da área rural. Saúde e Sociedade, 24(3), 901-913. 
Oliveira, J. A. A., \& Teixeira, S. F. (1985). (Im)previdência social: 60 anos de história da Previdência no Brasil. Petrópolis, RJ: Vozes.

Oliveira, L. C., \& Pinheiro, R. (2010). A participação nos conselhos de saúde e sua interface com a cultura política. Ciência \& Saúde Coletiva, 15, 2455-2464.

Oliveira, V. C. (1995). Os mídias e a mitificação das tecnologias em saúde. In A. M. R. Pitta (Org.), Saúde \& comunicação: Visibilidades e silêncios (pp. 25-37). São Paulo, SP: Hucitec.

Organização Mundial da Saúde. (2010a). Financiamento dos sistemas de saúde: O caminho para a cobertura universal (Relatório mundial de saúde). Genebra, Suíça: OMS.

Organização Mundial da Saúde. (2010b). Redução das desigualdades no período de uma geração. Igualdade na saúde através da ação sobre os seus determinantes sociais (Relatório final da Comissão para os Determinantes Sociais da Saúde). Genebra, Suíça: OMS.

Organização Mundial da Saúde. (2013). Pesquisa para a cobertura universal de saúde (Relatório mundial da saúde). Genebra, Suíça: Organização Mundial da Saúde.

Parker, R., \& Aggleton, P. (2001). Estigma, discriminação e aids. Rio de Janeiro, RJ: Associação Brasileira Interdisciplinar de Aids.

Pestana, M., Tavares Júnior, F., \& Mendes, E. V. (2009). Bases conceituais e programáticas do choque de gestão na saúde em Minas Gerais. Painel apresentado no Segundo Congresso Consad de Gestão Pública. Recuperado de http://consad.org.br/wpcontent/uploads/2013/02/bases-conceituais-e-programaticas-do-choque-de-gestão-nasaúde-em-minas-gerais2.pdf

Piovesan A., \& Temporini, E. R. (1995). Pesquisa exploratória: Procedimento metodológico para o estudo de fatores humanos no campo da saúde pública. Revista de Saúde Pública, 29, 318-325.

Pope, C., \& Mays, N. (2005). Pesquisa qualitativa na atenção à saúde (A. P. Fajardo, Trad., 2a ed.). Porto Alegre, RS: Artmed.

Portela, G. Z., \& Ribeiro, J. M. (2011). A sustentabilidade econômico-financeira da Estratégia Saúde da Família em municípios de grande porte. Ciência \& Saúde Coletiva, 16, 17191732 . 
Puccini, P. T., \& Cecílio, L. C. O. (2004). A humanização dos serviços e o direito à saúde. Cadernos de Saúde Pública, 20, 1342-1353.

Q\&A: US healthcare reform. (2010, March 22). BBC News. Recuperado de http://news.bbc.co.uk/1/hi/8160058.stm

Rego, W. L. (2008). Aspectos teóricos das políticas de cidadania: Uma aproximação ao Bolsa Família. Lua Nova: Revista de Cultura e Política, 73, 147-185.

Rocha, R. (2009). A gestão descentralizada e participativa das políticas públicas no Brasil. Revista Pós Ciências Sociais, 6(11), 41-57.

Rondelli, E. (1995). Mídia e saúde: Os discursos se entrelaçam. In A. M. R. Pitta (Org.), Saúde \& comunicação: Visibilidades e silêncios (pp. 38-47). São Paulo, SP: Hucitec.

Rosa, A. M., \& Marcellino Junior, J. C. M. (2011). O Estado democrático de direito e os direitos fundamentais sociais: (In)efetividade em tempos de prevalência da lógica econômica. Unisul de Fato e de Direito, 1(2), 47-55.

Rozemberg, B., \& Minayo, M. C. S. (2001). A experiência complexa e os olhares reducionistas. Ciência \& Saúde Coletiva, 6(1), 115-123.

Sallum Júnior, B. (2003). Metamorfoses do Estado brasileiro no final do século XX. Revista Brasileira de Ciências Sociais, 18(52), 35-55.

Sanchez, R. M., \& Ciconelli, R. M. (2012). Conceitos de acesso à saúde. Revista Panamericana de Salud Pública, 31, 260-268.

Santos, J. A. F. (2011). Classe social e desigualdade de saúde no Brasil. Revista Brasileira de Ciências Sociais, 26(75), 27-55.

Santos, P. L. P. (2013). Mercantilização da saúde e cidadania perdida: O papel do SUS na reafirmação da saúde como direito social. Revista da UNIFEBE, 1(11), 1-18.

Santos, V. G. (1979). Do laissez-faire repressivo à cidadania em recesso. In Cidadania e justiça: A política social na ordem brasileira (Contribuições em ciências sociais, Vol. 1, pp. 71-82). Rio de Janeiro, RJ: Campus. 
Sarlet, I. W., \& Figueiredo, M. F. (2009). Algumas considerações sobre o direito fundamental à proteção e promoção da saúde aos 20 anos da Constituição Federal de 1988. In T. M. M. Keinert, S. H. B. Paula, \& J. R. A. Bonfim (Orgs.), As ações judiciais no SUS e a promoção do direito à saúde (Vol. 10, pp. 25-62) São Paulo, SP: Instituto de Saúde.

Sarreta, F. O. (2009). Educação permanente em saúde para os trabalhadores do SUS. São Paulo, SP: Editora UNESP.

Secretaria de Estado de Saúde de Minas Gerais. (2012). Plano Diretor de Regionalização $(P D R)$. Recuperado de http://www.saude.mg.gov.br/parceiro/regionalizacao-pdr2

Secretaria de Estado de Saúde de Minas Gerais. Superintendência Regional de Saúde de Uberaba. (2013). Diagnóstico situacional: Saúde: Macrorregião Triângulo Sul. Uberaba, MG: SES/MG/SRS/URA. Recuperado de http://www.mpmg.mp.br/lumis/ portal/file/fileDownload.jsp?fileId=8A91CFAA42E2BC3E0143720F01AA1DA7

Senna, M. C. M., Costa, A. M., \& Silva, L. N. (2010). Atenção à saúde em grandes centros urbanos: Desafios à consolidação do SUS. Sociedade em Debate, 16(1), 121-137.

Serrano, M. A. M. (2012). O Sistema Único de Saúde e suas diretrizes constitucionais (2a ed.). São Paulo, SP: Verbatim.

Silva, G. R. (1995). O SUS e a crise atual do setor público da saúde. Saúde \& Sociedade, 4, $15-21$.

Silva, M. K. (2006). Sociedade civil e construção democrática: Do maniqueísmo essencialista à abordagem relacional. Sociologias, 16, 156-179.

Silva, S. F. (2011). Organização de redes regionalizadas e integradas de atenção à saúde: desafios do Sistema Único de Saúde (Brasil). Ciência \& Saúde Coletiva, 16, 2753-2762.

Simionatto, I. (2009). Classes subalternas, lutas de classe e hegemonia: Uma abordagem gramsciana. Revista Katálysis, 12, 41-49.

Souza, E. (2014). Critérios para a liberação de "stent" farmacológico pela Secretaria Municipal de Saúde Comarca de Uberaba-MG. Recuperado de http://www.ebserh. gov.br/documents/147715/148046/relacao_de_solicitacao_de_stent_farmacologico_ano_ 2013.pdf/a038a511-130b-4db5-8219-e7d7bbe176f2 
Skalinski, L. M., \& Praxedes, W. L. A. (2003). A abordagem marxista aplicada aos métodos de investigação em saúde. Acta Scientiarum. Human and Social Sciences, 25(2), 305-316.

Souza, J. (2009). Ralé brasileira: Quem é e como vive. Belo Horizonte, MG: Editora UFMG.

Starr, P. (1992). The logic of health-care reform. In The Grand Rounds Press (pp. 43-51). Whittle Direct Books. Recuperado de https://www.princeton.edu/ starr/HealthReform /Logic92_Complete.pdf

Telles, V. S. (1998). Direitos sociais: Afinal, do que se trata? Revista USP, (37), 34-45.

Triviños, A. N. S. (1987). Introdução à pesquisa em Ciências Sociais: A pesquisa qualitativa em educação. São Paulo, SP: Atlas.

Turato, E. R. (2003). Tratado da metodologia da pesquisa clínico-qualitativa: Construção teórico-epistemológica, discussão comparada e aplicação nas áreas da saúde e humanas (2a ed.). Petrópolis, RJ: Vozes.

US healthcare law: Republicans bid to overturn reform. (2011, January 4). BBC News. Recuperado de http://www.bbc.co.uk/news/world-us-canada-12113273

Vaitsman, J. (1989). Corporativismo: Notas para sua aplicação no campo da saúde. In S. F. Teixeira (Org.), Reforma sanitária: Em busca de uma teoria (pp. 139-156). São Paulo, SP: Cortez.

Viacava, F. (2010). Acesso e uso de serviços de saúde pelos brasileiros. RADIS: Comunicação em Saúde, (96), 12-19.

Vianna, C. M. M. (2002). Estruturas do sistema de saúde: Do complexo médico-industrial ao médico-financeiro. Physis: Revista de Saúde Coletiva, 12, 375-390.

Vieira, F. S. (2008). Ações judiciais e direito à saúde: Reflexão sobre a observância aos princípios do SUS. Revista de Saúde Pública, 42, 365-369.

Vieira, L. (2001). Notas sobre o conceito de cidadania. Revista Brasileira de Informação Bibliográfica em Ciências Sociais - BIB, (51), 35-47. 
Weber, M. H. (1995). Comunicação: Estratégia vital para a saúde. In A. M. R. Pitta (Org.), Saúde \& comunicação: Visibilidades e silêncios (pp. 151-165). São Paulo, SP: Hucitec.

Wong Un, J. A. (2002). Visões de comunidade na saúde: comunalidade, interexistência e experiência poética. (Tese de doutorado, Fundação Oswaldo Cruz). Recuperado de http://portalteses.icict.fiocruz.br/pdf/FIOCRUZ/2002/wongunjad/capa.pdf

Zambon, V. D., \& Ogata, M. N. (2011). Configurações dos Conselhos Municipais de Saúde de uma região no Estado de São Paulo. Revista da Escola de Enfermagem da USP, 45, 890-897. 
APÊNDICES 

APÊNDICE A - TERMO DE AUTORIZAÇÃO PARA COLETA DE DADOS.

PROGRAMA DE PÓS-GRADUAÇÃO EM PSICOLOGIA

FACULDADE DE FILOSOFIA CIÊNCIAS E LETRAS DE RIBEIRÃO PRETO-USP

\section{Termo de Autorização para Coleta de Dados}

Eu, Prof. Dr. Valdemar Hial, Presidente Regional do Colegiado dos Secretários Municipais de Saúde (COSEMS) Uberaba e Secretário Municipal de Saúde do Municipio de Uberaba declaro estar ciente e de acordo com a pesquisa que será realizada na Macrorregião Triângulo Sul pelo aluno de doutorado da Faculdade de Filosofia Ciências e Letras de Ribeirão Preto (USP) Edward Meirelles de Oliveira, sob orientação do Prof. Dr. Marco Antonio de Castro Figueiredo com o tema "Gestão do Sistema Único de Saúde (SUS): um estudo em nove municípios do Triângulo Mineiro".

Declaro que tenho conhecimento sobre o projeto a ser desenvolvido e os procedimentos a serem realizados, estando ciente que não afetarão o desenvolvimento das atividades normais das Secretarias Municipais de Saúde dos municípios participantes, colocando o COSEMS e todas suas atividades (reuniões, atas, etc.) a disposição do aluno.

Por ser verdade, firmo o presente.

Uberaba, 04 de outubro de 2011.

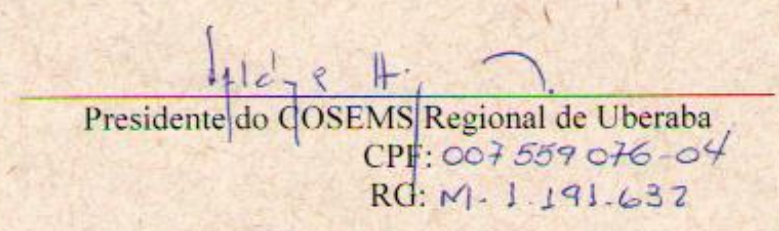




\section{APÊNDICE B - TERMO DE CONSENTIMENTO LIVRE E ESCLARECIDO, PARA ENTREVISTA FILMADA.}

Eu, Edward Meirelles de Oliveira, enfermeiro, RG: 33.964.623-8, vinculado à Faculdade de Filosofia, Ciências e Letras de Ribeirão Preto - USP, como aluno de doutorado do Programa de PósGraduação em Psicologia, sob orientação do Professor Doutor Marco Antonio de Castro Figueiredo, psicólogo e professor desta Faculdade, estamos realizando um estudo para compreender o ponto de vista das pessoas em relação à gestão do Sistema Único de Saúde - SUS. Para isso precisamos de sua colaboração e gostaríamos de poder contar com sua participação. Para participar você deve estar ciente de que:
A. Sua participação é inteiramente voluntária e dar-se-á por meio de uma entrevista;
B. Sua entrevista será filmada e posteriormente transcrita;
C. As informações que você fornecer serão utilizadas em trabalhos científicos;
D. O seu anonimato será garantido, nos resultados obtidos e no momento da produção dos textos;
E. Você terá acesso a todos os dados deste estudo (gravações e trabalhos realizados);
F. Não há nenhum risco em participar deste estudo;
G. Você estará livre para desistir da participação no trabalho em qualquer momento, por qualquer motivo, sem que isso implique em qualquer prejuízo, tendo suas informações excluídas do estudo;

H. Você ficará com uma cópia assinada desse termo de consentimento;

I. Este estudo foi aprovado pelo Comitê de Ética em Pesquisa com Seres Humanos da FFCLRP - USP.

J. Qualquer dúvida com relação a sua participação poderá ser esclarecida com o pesquisador responsável ou com o orientador da pesquisa nos seguintes endereços:

Rua Sílvio Crema, 414. CEP. 38190-000 - Sacramento - MG. Fones: (34) 3351- 3241/ (34) 88310464 - e-mail: edmeirelles@usp.br ou Faculdade de Filosofia, Ciências e Letras Departamento de Psicologia e Educação - Bloco 5 (C. P. A.) Av. Bandeirantes, ${ }^{\circ} .3900$ - CEP: 14040-901 - Ribeirão Preto/SP. Fone: (16) 3602 - 3726 ou 3602 - 3786.

Considerando as questões acima:

$\mathrm{Eu}$, estou ciente e

aceito participar voluntariamente do presente estudo.

Assinatura do Participante

Edward Meirelles de Oliveira

(Pesquisador Responsável)

Obrigado pela sua atenção e colaboração! 


\section{APÊNDICE C - TERMO DE CONSENTIMENTO LIVRE E ESCLARECIDO, PARA ENTREVISTA ÁUDIO-GRAVADA.}

Eu, Edward Meirelles de Oliveira, enfermeiro, RG: 33.964.623-8, vinculado à Faculdade de Filosofia, Ciências e Letras de Ribeirão Preto - USP, como aluno de doutorado do Programa de PósGraduação em Psicologia, sob orientação do Professor Doutor Marco Antonio de Castro Figueiredo, psicólogo e professor desta Faculdade, estamos realizando um estudo para compreender o ponto de vista das pessoas em relação à gestão do Sistema Único de Saúde - SUS. Para isso precisamos de sua colaboração e gostaríamos de poder contar com sua participação. Para participar você deve estar ciente de que:

A. Sua participação é inteiramente voluntária e dar-se-á por meio de uma entrevista;

B. Sua entrevista será áudio-gravada e posteriormente transcrita;

C. As informações que você fornecer serão utilizadas em trabalhos científicos;

D. O seu anonimato será garantido, nos resultados obtidos e no momento da produção dos textos;

E. Você terá acesso a todos os dados deste estudo (gravações e trabalhos realizados);

F. Não há nenhum risco em participar deste estudo;

G. Você estará livre para desistir da participação no trabalho em qualquer momento, por qualquer motivo, sem que isso implique em qualquer prejuízo, tendo suas informações excluídas do estudo;

H. Você ficará com uma cópia assinada desse termo de consentimento;

I. Este estudo foi aprovado pelo Comitê de Ética em Pesquisa com Seres Humanos da FFCLRP - USP.

J. Qualquer dúvida com relação a sua participação poderá ser esclarecida com o pesquisador responsável ou com o orientador da pesquisa nos seguintes endereços:

Rua Sílvio Crema, 414. CEP. 38190-000 - Sacramento - MG. Fones: (34) 3351- 3241/ (34) 88310464 - e-mail: edmeirelles@usp.br ou Faculdade de Filosofia, Ciências e Letras Departamento de Psicologia e Educação - Bloco 5 (C. P. A.) Av. Bandeirantes, $n^{\circ} .3900$ - CEP: 14040-901 - Ribeirão Preto/SP. Fone: (16) 3602 - 3726 ou 3602 - 3786.

Considerando as questões acima:

$\mathrm{Eu}$, estou ciente e

aceito participar voluntariamente do presente estudo.

Assinatura do Participante

Edward Meirelles de Oliveira

(Pesquisador Responsável)

Obrigado pela sua atenção e colaboração! 
APÊNDICE D - Recortes, unidades temáticas e notações relacionadas ao conteúdo das entrevistas analisadas. Perspectivas dos Secretários Municipais de Saúde (Gestores do Sistema Único de Saúde - SUS) - Síntese final.

Quadro 1. Unidades temáticas relacionadas à Categoria 1 - Racionalidades do Sistema Único de Saúde

\begin{tabular}{|c|c|c|c|}
\hline $\begin{array}{l}\text { UNIDADE } \\
\text { TEMÁTICA }\end{array}$ & ITEM & RECORTE & NOTAÇÃO \\
\hline \multirow{5}{*}{$\begin{array}{l}\text { Universalidade } \\
\text { Regulada }\end{array}$} & 1.1 & $\begin{array}{l}\text { Eu considero o SUS o melhor plano universal que nós temos. Melhor plano do mundo, } \\
\text { considerando o aspecto social! Porém já está na hora de repensarmos o SUS. (S.MGP) }\end{array}$ & \multirow{5}{*}{$\begin{array}{l}\text { Os critérios para "provisão" } \\
\text { do acesso universal ao SUS } \\
\text { parecem estar } \\
\text { limitados/regulados pelo } \\
\text { aspecto socioeconômico, } \\
\text { devendo-se garantir } \\
\text { universalidade de acesso } \\
\text { apenas àqueles que não podem } \\
\text { pagar pela assistência privada } \\
\text { (planos de saúde ou } \\
\text { desembolso direto); aos } \\
\text { demais, com suposta condição } \\
\text { econômica para pagar pelos } \\
\text { serviços de saúde ou } \\
\text { detentores de qualquer tipo de } \\
\text { plano privado de saúde, a } \\
\text { universalidade seria limitada, } \\
\text { regulada ou inaceitável. }\end{array}$} \\
\hline & 1.2 & O aspecto mais positivo do SUS é que ele atende a todos. (S.MPP) & \\
\hline & 1.3 & O mais importante no SUS é a universalidade, a equidade e a integralidade. (S.MGP) & \\
\hline & 1.5 & $\begin{array}{l}\text { Eu acho que a universalidade deveria ser direcionada, você não tem condições financeiras, tudo } \\
\text { bem. Se tem! Você teria que aguardar, não sei se eu estou conseguindo me expressar (S.MMP). }\end{array}$ & \\
\hline & 1.6 & $\begin{array}{l}\text { Há um grande erro na origem, a partir do momento em que se diz: a saúde é direito de todos e } \\
\text { dever do Estado, então o bacana que é milionário pode também requerer um atendimento? } \\
\text { (S.MGP) }\end{array}$ & \\
\hline
\end{tabular}


APÊNDICE D - Recortes, unidades temáticas e notações relacionadas ao conteúdo das entrevistas analisadas. Perspectivas dos Secretários Municipais de Saúde (Gestores do Sistema Único de Saúde - SUS) - Síntese final.

Quadro 2. Continuação - Unidades temáticas relacionadas à Categoria 1 - Racionalidades do Sistema Único de Saúde

\begin{tabular}{|c|c|c|c|}
\hline $\begin{array}{c}\text { UNIDADE } \\
\text { TEMÁTICA }\end{array}$ & ITEM & RECORTE & NOTAÇÃO \\
\hline \multirow{3}{*}{$\begin{array}{c}\text { Universalidade } \\
\text { Regulada }\end{array}$} & 1.9 & $\begin{array}{l}\text { De bom! Eu vejo que é um modelo que é exemplo no mundo, que veio contribuir muito pós- } \\
\text { Constituição Federal de 1988, trouxe um rumo para a saúde no país, principalmente para as } \\
\text { pessoas carentes, de menos recursos, menor renda, que não tinham assistência e viviam de } \\
\text { favores das Santas Casas, na época nem era INAMPS. (S.MGP) }\end{array}$ & \multirow{3}{*}{$\begin{array}{c}\text { Os critérios para "provisão" } \\
\text { do acesso universal ao SUS } \\
\text { parecem estar } \\
\text { limitados/regulados pelo } \\
\text { aspecto socioeconômico, } \\
\text { devendo-se garantir } \\
\text { universalidade de acesso } \\
\text { apenas àqueles que não podem } \\
\text { pagar pela assistência privada } \\
\text { (planos de saúde ou } \\
\text { desembolso direto); aos } \\
\text { demais, com suposta condição } \\
\text { econômica para pagar pelos } \\
\text { serviços de saúde ou } \\
\text { detentores de qualquer tipo de } \\
\text { plano privado de saúde, a } \\
\text { universalidade seria limitada, } \\
\text { regulada ou inaceitável. }\end{array}$} \\
\hline & 1.10 & $\begin{array}{l}\text { Eu sou bem mais velha que você, antigamente ou você tinha o INPS ou o Fundo Rural, se } \\
\text { você pagasse você consultava. Então eu acho que tinha que ser direcionado. Se você trabalha } \\
\text { em uma empresa particular, você contribui com o "INPS", é descontado no salário do meu } \\
\text { marido quase R\$ 500,00 né? Então? Porque todo mundo não pode pagar de acordo com seu } \\
\text { nível econômico? Contribuir de acordo com seu grupo. (S.MMP) }\end{array}$ & \\
\hline & 1.11 & $\begin{array}{l}\text { Assim! A universalidade foi boa num certo ponto, mas ela sobrecarregou o SUS, que é novo, } \\
\text { tá começando agora. Então! Essa demanda grande, você ficar na fila muito tempo esperando } \\
\text { vaga com o especialista, é por isso! Porque deixou ao livre acesso da população. Então, eu } \\
\text { acho que deveria ter uma contribuição. Por mais que a gente já pague os impostos, eu acho } \\
\text { que deveria. (S.MMP) }\end{array}$ & \\
\hline
\end{tabular}


APÊNDICE D - Recortes, unidades temáticas e notações relacionadas ao conteúdo das entrevistas analisadas. Perspectivas dos Secretários Municipais de Saúde (Gestores do Sistema Único de Saúde - SUS) - Síntese final.

Quadro 3. Unidades temáticas relacionadas à Categoria 1 - Racionalidades do Sistema Único de Saúde

\begin{tabular}{|c|c|c|c|}
\hline $\begin{array}{c}\text { UNIDADE } \\
\text { TEMÁTICA }\end{array}$ & ITEM & RECORTE & NOTAÇÃO \\
\hline & 1.12 & $\begin{array}{l}\text { Quantas pessoas têm plano de saúde e deixam de usar seu plano de saúde para usar o SUS? É } \\
\text { justo? É o problema da universalidade! Como o SUS é universal essas pessoas se sentem no } \\
\text { direito de usar o SUS. (S.MGP) }\end{array}$ & \\
\hline \multirow{3}{*}{$\begin{array}{c}\text { Desigualdade } \\
\text { Social via } \\
\text { Dicotomia } \\
\text { Público/Privado }\end{array}$} & 1.13 & $\begin{array}{l}\text { Estão tentando desestruturar o SUS e deixar o plano de saúde entrar. Isso seria um } \\
\text { contrassenso. Eu vejo pela UNIMED, não sei se esse é um problema geral, mas a UNIMED } \\
\text { aqui não vive sem o SUS, ela suga o SUS. Vou te dar um exemplo que eu sei de perto aqui, a } \\
\text { UNIMED funciona bem por quê? Porque o município paga o plantonista na Santa Casa e esse } \\
\text { mesmo plantonista atende a UNIMED. Se o município não pagar o plantonista, não tem } \\
\text { atendimento de UNIMED na Santa Casa. O cara (o médico) não vai lá pra receber só o valor } \\
\text { que o convênio paga. (S.MGP) }\end{array}$ & \multirow{3}{*}{$\begin{array}{l}\text { As dificuldades para } \\
\text { “provisão" do acesso universal } \\
\text { ao SUS, parecem estar } \\
\text { relacionadas à dicotomia } \\
\text { público/privado, necessitando, } \\
\text { na visão dos gestores, maior } \\
\text { controle/regulação desta } \\
\text { relação, em que o setor } \\
\text { privado além de não ser } \\
\text { complementar, mas sim } \\
\text { concorrente, invade o SUS } \\
\text { produzindo e reproduzindo } \\
\text { relações de desigualdades } \\
\text { sociais. }\end{array}$} \\
\hline & 1.14 & $\begin{array}{l}\text { O sujeito começa a fazer um tratamento particular por um plano de saúde, um tratamento de } \\
\text { hemodiálise, de câncer, por exemplo! O plano não dá suporte, aí o sujeito já vem pro SUS. } \\
\text { Então se o sujeito fez todo o tratamento particular! por que ele não paga uma taxa? Por que na } \\
\text { hora do alto custo, da alta complexidade, ele corre para o SUS? Não! Então o sujeito teria que } \\
\text { contribuir com isso, porque aí você vai passar na frente de pessoas que estão aguardando há } \\
\text { muito tempo, você teria um jeito de burlar o sistema. (S.MMP) }\end{array}$ & \\
\hline & 1.17 & $\begin{array}{l}\text { Meu município fica a vinte minutos de Frutal e a meia hora de Barretos. A minha região é } \\
\text { circunvizinha por usinas, todo mundo tem algum tipo de plano de saúde. Então, vai nos } \\
\text { médicos dos planos que as usinas oferecem e querem a medicação pelo SUS. Eu estou tendo } \\
\text { esse problema por quê? Porque a população vai na rede privada e quer o medicamento do } \\
\text { SUS. (S.MMP) }\end{array}$ & \\
\hline
\end{tabular}


APÊNDICE D - Recortes, unidades temáticas e notações relacionadas ao conteúdo das entrevistas analisadas. Perspectivas dos Secretários Municipais de Saúde (Gestores do Sistema Único de Saúde - SUS) - Síntese final.

Quadro 4. Continuação - Unidades temáticas relacionadas à Categoria 1 - Racionalidades do Sistema Único de Saúde

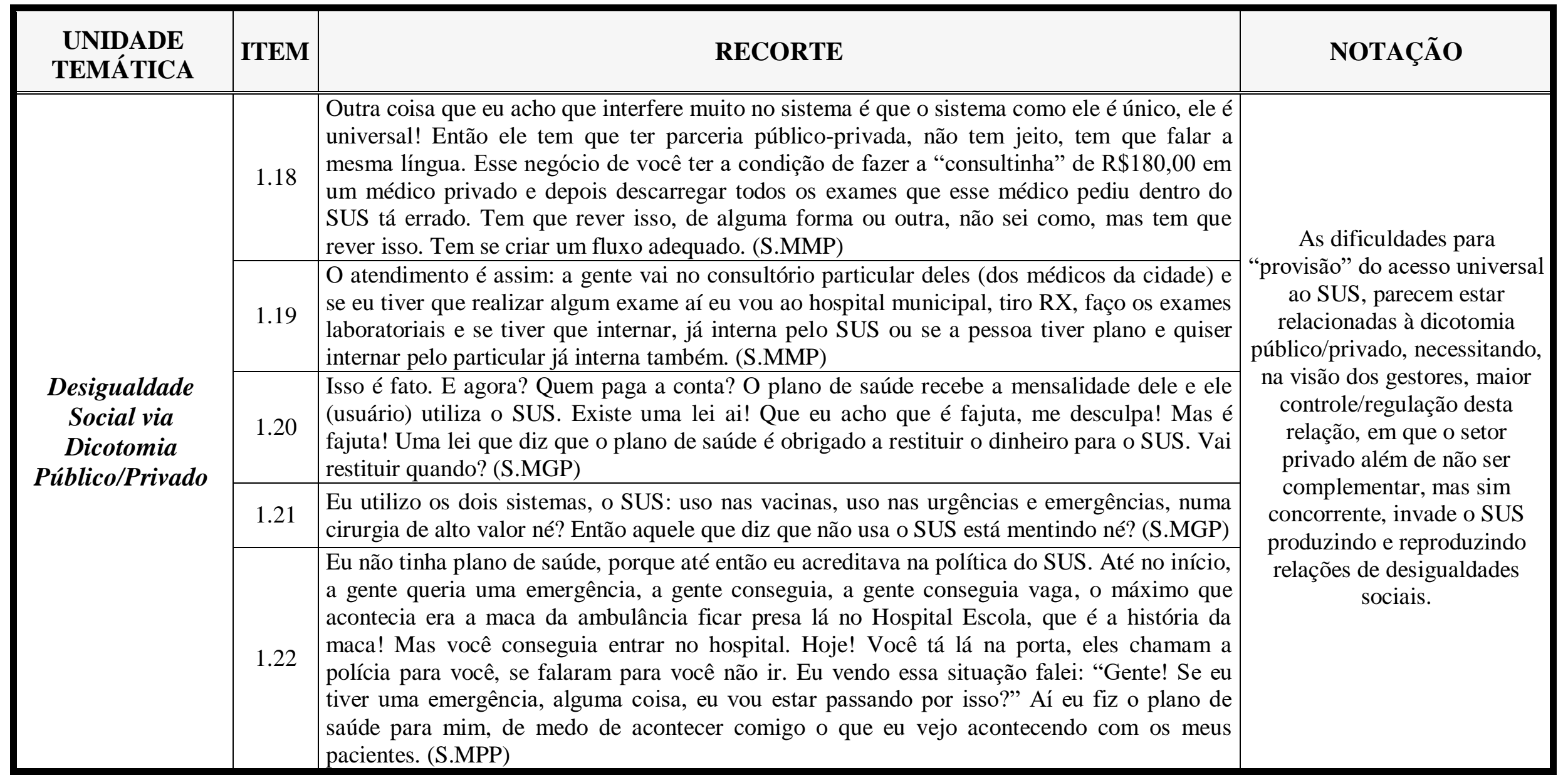


APÊNDICE D - Recortes, unidades temáticas e notações relacionadas ao conteúdo das entrevistas analisadas. Perspectivas dos Secretários Municipais de Saúde (Gestores do Sistema Único de Saúde - SUS) - Síntese final.

Quadro 5. Unidades temáticas relacionadas à Categoria 1 - Racionalidades do Sistema Único de Saúde

\begin{tabular}{|c|c|c|c|}
\hline $\begin{array}{c}\text { UNIDADE } \\
\text { TEMÁTICA }\end{array}$ & $\begin{array}{c}\text { ITE } \\
\text { M }\end{array}$ & RECORTE & NOTAÇÃO \\
\hline \multirow[b]{3}{*}{$\begin{array}{c}\text { Judicialização da } \\
\text { Saúde: } \\
\text { Desigualdade } \\
\text { injusta }\end{array}$} & 1.23 & $\begin{array}{l}\text { Secretaria de saúde hoje no Brasil é um encargo pesado. É uma missão, em determinados aspectos, } \\
\text { impossível, principalmente no que tange a nossa relação com o Ministério Público e com o } \\
\text { Judiciário. (S.MGP) }\end{array}$ & \multirow{3}{*}{$\begin{array}{l}\text { Judicialização - } \\
\text { privatização/individualizaç } \\
\text { ão da saúde. } \\
\text { Esta questão faz a } \\
\text { reificação ser colocada em } \\
\text { vários níveis. } \\
\text { Oculta a luta de classes que } \\
\text { permanece como um } \\
\text { critério de exclusão. } \\
\text { As questões de apropriação } \\
\text { têm que passar pelo } \\
\text { reconhecimento da } \\
\text { cidadania. } \\
\text { No ponto de vista geral } \\
\text { vemos que há um } \\
\text { contingente muito grande } \\
\text { de pessoas que estão no } \\
\text { limbo. }\end{array}$} \\
\hline & 1.24 & $\begin{array}{l}\text { Na verdade, a judicialização simplesmente é.... E isso eu falei para a promotora! A judicialização na } \\
\text { verdade nada mais é do que o fura fila, não tem discussão! O Ministério Público não está fazendo o } \\
\text { papel dele, tá furando a fila do sistema que é nacional, que existe uma lei, uma ordem.... E cada vez } \\
\text { mais o usuário está aprendendo a furar essa fila, então ele paga a consulta do cardiologista, a } \\
\text { consulta do outro especialista, então ele vai para o promotor, então não tem jeito, eu tenho uma fila } \\
\text { de espera, se você for judicializar a secretaria, tem que lembrar que tem gente que está a seis meses } \\
\text { esperando lá! E o cara que está a um mês vai passar na frente? (S.MMP) }\end{array}$ & \\
\hline & 1.25 & $\begin{array}{l}\text { Eu não tinha controle se os pedidos vinham do particular ou do SUS, mas nós sabíamos, por } \\
\text { exemplo, e isso é uma questão muito séria, que alguns medicamentos ou pedidos que eram feitos, } \\
\text { não tinham nem o aval científico. Mas o advogado entra, por quê? Porque o médico, infelizmente, lê } \\
\text { um trabalho científico que fala que já existia tal produto nos EUA, que estava sendo testado e ele } \\
\text { queria testar aqui também. E atrás disso existe outras coisas muito perigosas para serem avaliadas. } \\
\text { Por exemplo, porque certos medicamentos, de um determinado laboratório, são sempre pedidos por } \\
\text { determinados médicos? Precisa ser questionado isso também? Você tem laboratórios que oferecem } \\
\text { aos médicos salários extras, viagens, todos os custos de congressos, etc. E o SUS é obrigado a } \\
\text { cobrir? (S.MGP) }\end{array}$ & \\
\hline
\end{tabular}


APÊNDICE D - Recortes, unidades temáticas e notações relacionadas ao conteúdo das entrevistas analisadas. Perspectivas dos Secretários Municipais de Saúde (Gestores do Sistema Único de Saúde - SUS) - Síntese final.

Quadro 6. Continuação - Unidades temáticas relacionadas à Categoria 1 - Racionalidades do Sistema Único de Saúde

\begin{tabular}{|c|c|c|c|}
\hline $\begin{array}{c}\text { UNIDADE } \\
\text { TEMÁTICA }\end{array}$ & ITEM & RECORTE & NOTAÇÃO \\
\hline \multirow{3}{*}{$\begin{array}{c}\text { Judicialização da } \\
\text { Saúde: } \\
\text { Desigualdade } \\
\text { injusta }\end{array}$} & 1.27 & Teve um paciente que eu paguei quase noventa mil reais em stent farmacológico. (S.MMP) & \multirow{3}{*}{$\begin{array}{c}\text { Judicialização - } \\
\text { privatização/individualização } \\
\text { da saúde. } \\
\text { Esta questão faz a reificação } \\
\text { ser colocada em vários níveis. } \\
\text { Oculta a luta de classes que } \\
\text { permanece como um critério } \\
\text { de exclusão. } \\
\text { As questões de apropriação } \\
\text { têm que passar pelo } \\
\text { reconhecimento da cidadania. } \\
\text { No ponto de vista geral vemos } \\
\text { que há um contingente muito } \\
\text { grande de pessoas que estão } \\
\text { no limbo. }\end{array}$} \\
\hline & 1.29 & $\begin{array}{l}\text { É isso que eu vou te falar, o que que acontece! A ouvidoria do Hospital Escola é.... fez um } \\
\text { relatório da situação do paciente, mas ela não tem que identificar o responsável, porque a } \\
\text { ouvidoria tá careca de saber que, se é tripartite e se o alto custo não é responsabilidade do } \\
\text { município, ele não teria que identificar ninguém, porque nesse momento eu poderia fazer } \\
\text { minha negativa, fazendo a justificativa de que o stent farmacológico está dentro do } \\
\text { procedimento da internação, automaticamente, se ele está num hospital de alta complexidade, } \\
\text { então, teoricamente, o pagamento desse procedimento não é meu de forma alguma. Então eu } \\
\text { poderia fundamentar a minha negativa e a defensoria poderia ter entrado apenas contra o } \\
\text { Estado e a União, mas não! Como eles identificaram a Secretaria Municipal de Saúde, acabou } \\
\text { que eu também tive que ser intimada e nessa intimação eu tive que fornece, porque o paciente } \\
\text { estava internado lá e, com risco de vida. Foram vinte e quatro mil reais! Que eu não precisaria } \\
\text { ter arcado com isso. O Estado poderia ter arcado, porque na verdade a gente sabe que o Estado } \\
\text { acaba não aplicando cem por cento do que ele deveria aplicar em saúde, então, nós estamos } \\
\text { aplicando. É isso que é confuso, porque as nossas próprias entidades acabam por fazer } \\
\text { algumas coisas de forma.... De forma incorreta como foi esse caso, porque eles identificaram a } \\
\text { Secretaria Municipal. (S.MGP) }\end{array}$ & \\
\hline & 1.30 & $\begin{array}{l}\text { Tem hora que eu sou judicializado por medicamento que eu tenho na farmácia básica! } \\
\text { (S.MMP) }\end{array}$ & \\
\hline
\end{tabular}


APÊNDICE D - Recortes, unidades temáticas e notações relacionadas ao conteúdo das entrevistas analisadas. Perspectivas dos Secretários Municipais de Saúde (Gestores do Sistema Único de Saúde - SUS) - Síntese final.

Quadro 7. Continuação - Unidades temáticas relacionadas à Categoria 1 - Racionalidades do Sistema Único de Saúde

\begin{tabular}{|c|c|c|c|}
\hline $\begin{array}{l}\text { UNIDADE } \\
\text { TEMÁTICA }\end{array}$ & ITEM & RECORTE & NOTAÇÃO \\
\hline \multirow{5}{*}{$\begin{array}{l}\text { Judicialização da } \\
\text { Saúde: } \\
\text { Desigualdade } \\
\text { injusta }\end{array}$} & 1.31 & $\begin{array}{l}\text { Quando eu não tenho o medicamento de marca, aí complica todo o esquema. Faz auxílio, vai } \\
\text { para o jurídico, alguns trocam receitas, a gente não tem como monitorar isso tudo, mas } \\
\text { fornece todos os medicamentos que eles procuram, porque eles também tentam, vão no } \\
\text { Ministério Público e a gente também fica numa situação difícil. (S.MMP) }\end{array}$ & \multirow{5}{*}{$\begin{array}{c}\text { Judicialização - } \\
\text { privatização/individualização } \\
\text { da saúde. } \\
\text { Esta questão faz a reificação } \\
\text { ser colocada em vários níveis. } \\
\text { Oculta a luta de classes que } \\
\text { permanece como um critério } \\
\text { de exclusão. } \\
\text { As questões de apropriação } \\
\text { têm que passar pelo } \\
\text { reconhecimento da cidadania. } \\
\text { No ponto de vista geral vemos } \\
\text { que há um contingente muito } \\
\text { grande de pessoas que estão } \\
\text { no limbo. }\end{array}$} \\
\hline & 1.32 & $\begin{array}{l}\text { Vou te citar um exemplo claro, eu gastei o ano passado (2012) } 4 \text { milhões e quinhentos mil } \\
\text { reais com mandatos judiciais e gastei com a atenção básica, para a cesta básica de remédios } \\
\text { (RMUME), dois milhões e oitocentos mil. É justo? Quer dizer, eu gastei dois milhões e } \\
\text { oitocentos mil para atender } 46 \text { mil pacientes e } 4 \text { milhões e quinhentos mil para atender } 500 \\
\text { pacientes. (S.MGP) }\end{array}$ & \\
\hline & 1.33 & $\begin{array}{l}\text { Chegou um ponto em que o usuário chega na rua e fala: "eu só consegui o remédio porque eu } \\
\text { fui na juíza". (S.MMP) }\end{array}$ & \\
\hline & 1.34 & $\begin{array}{l}\text { Eu conheço uma determinada família aqui no município, que eu fui obrigado a comprar } \\
\text { hormônio de crescimento e é uma das famílias mais abastadas do município. Eu sei. Eu } \\
\text { conheço a família. (S.MGP) }\end{array}$ & \\
\hline & 1.35 & $\begin{array}{l}\text { Eu acabei de receber agora, você viu! Uma intimação da promotora dizendo que não houve } \\
\text { cumprimento de mandatos judiciais na compra de medicamentos. Agora! Esses medicamentos } \\
\text { foram pedidos via judicial por intermédio de indivíduos que tinham condição de pagar } \\
\text { advogado. Ele contratou um advogado para isso. Ora! Se esse indivíduo tem condição de } \\
\text { pagar um advogado, você não acha que é injusto o que ele está fazendo com o resto do pessoal } \\
\text { da nação que realmente necessita desse medicamento? Ele fura a fila! E no momento que ele } \\
\text { fura a fila o que é que ocorre? Ele nos coloca em uma situação difícil, ou seja, eu deixo de } \\
\text { atender } 100 \text { para atender 1, pelo mesmo valor. É uma "Escolha de Sofia", você tem que fazer. } \\
\text { (S.MGP) }\end{array}$ & \\
\hline
\end{tabular}


APÊNDICE D - Recortes, unidades temáticas e notações relacionadas ao conteúdo das entrevistas analisadas. Perspectivas dos Secretários Municipais de Saúde (Gestores do Sistema Único de Saúde - SUS) - Síntese final.

Quadro 8. Continuação - Unidades temáticas relacionadas à Categoria 1 - Racionalidades do Sistema Único de Saúde

\begin{tabular}{|c|c|c|c|}
\hline $\begin{array}{c}\text { UNIDADE } \\
\text { TEMÁTICA }\end{array}$ & ITEM & RECORTE & NOTAÇÃO \\
\hline $\begin{array}{c}\text { Judicialização da } \\
\text { Saúde: } \\
\text { Desigualdade } \\
\text { injusta }\end{array}$ & 1.36 & $\begin{array}{l}\text { Então, acaba que a gente nunca chega a ter ação judicial, a gente sempre faz antes sabe? Por } \\
\text { isso que eu não tenho demanda judicial. Não é o correto, até tem vez que eu falo "gente, entra } \\
\text { judicialmente", que a gente fica até mais resguardado né? Quando entra judicialmente, quando } \\
\text { você compra, você tem a ordem judicial, você está resguardado. Eu tenho medo dessas coisas, } \\
\text { para fugir da judicialização, a gente acaba fazendo coisa errada, comprando sem licitação, } \\
\text { compra um, outro! E aí vem a dificuldade, mais uma dificuldade, porque aqui não tem nada } \\
\text { (Fórum, escritório de advocacia, etc.). Pra judicializar tem que ir na cidade vizinha e } \\
\text { normalmente o usuário não vai. (S.MPP) }\end{array}$ & $\begin{array}{c}\text { Judicialização - } \\
\text { privatização/individualização } \\
\text { da saúde. } \\
\text { Esta questão faz a reificação } \\
\text { ser colocada em vários níveis. } \\
\text { Oculta a luta de classes que } \\
\text { permanece como um critério } \\
\text { de exclusão. } \\
\text { As questões de apropriação } \\
\text { têm que passar pelo } \\
\text { reconhecimento da cidadania. } \\
\text { No ponto de vista geral vemos } \\
\text { que há um contingente muito } \\
\text { grande de pessoas que estão } \\
\text { no limbo. }\end{array}$ \\
\hline
\end{tabular}


APÊNDICE D - Recortes, unidades temáticas e notações relacionadas ao conteúdo das entrevistas analisadas. Perspectivas dos Secretários Municipais de Saúde (Gestores do Sistema Único de Saúde - SUS) - Síntese final.

Quadro 9. Continuação - Unidades temáticas relacionadas à Categoria 1 - Racionalidades do Sistema Único de Saúde

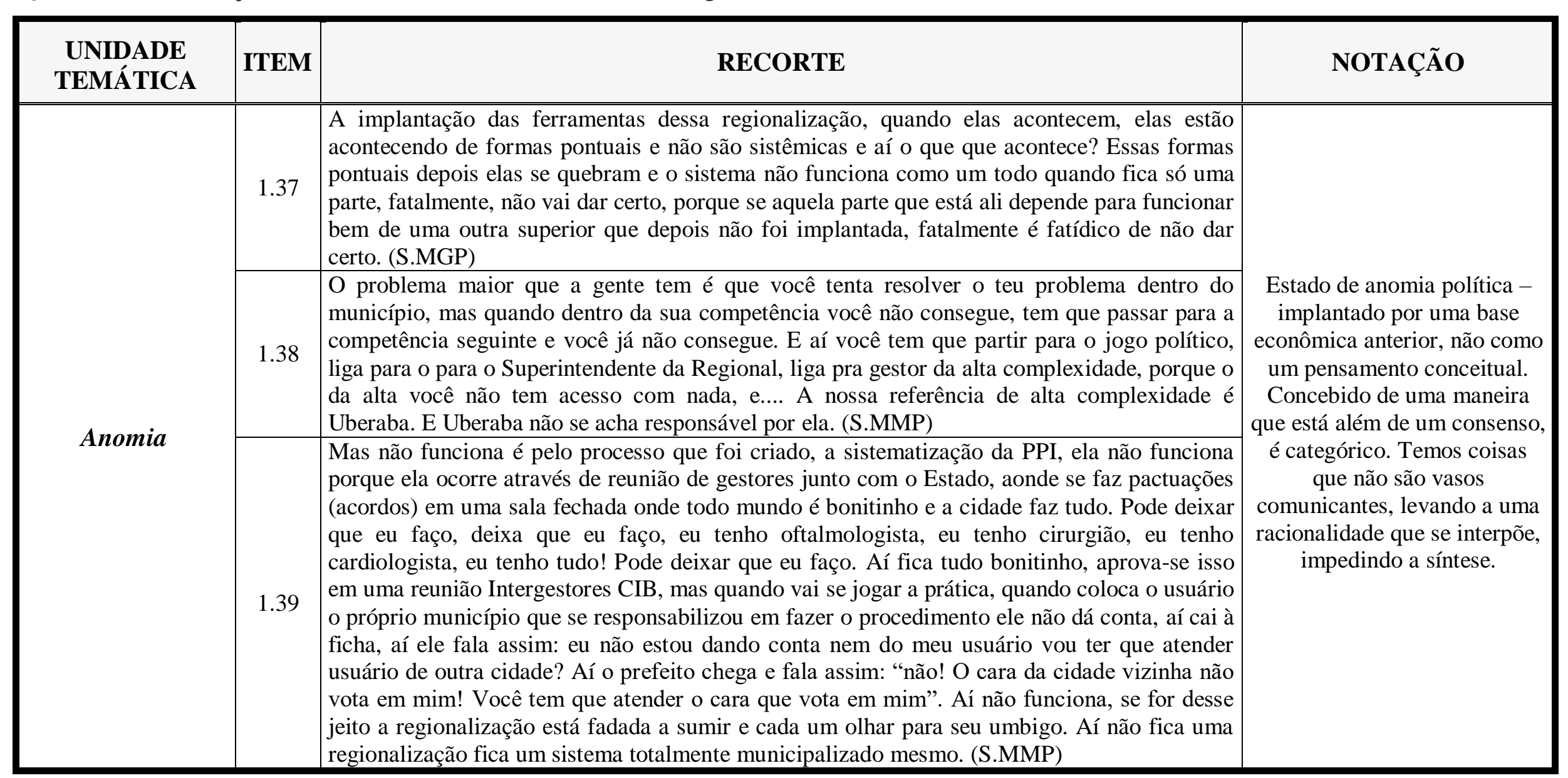


APÊNDICE D - Recortes, unidades temáticas e notações relacionadas ao conteúdo das entrevistas analisadas. Perspectivas dos Secretários Municipais de Saúde (Gestores do Sistema Único de Saúde - SUS) - Síntese final.

Quadro 10. Continuação - Unidades temáticas relacionadas à Categoria 1 - Racionalidades do Sistema Único de Saúde

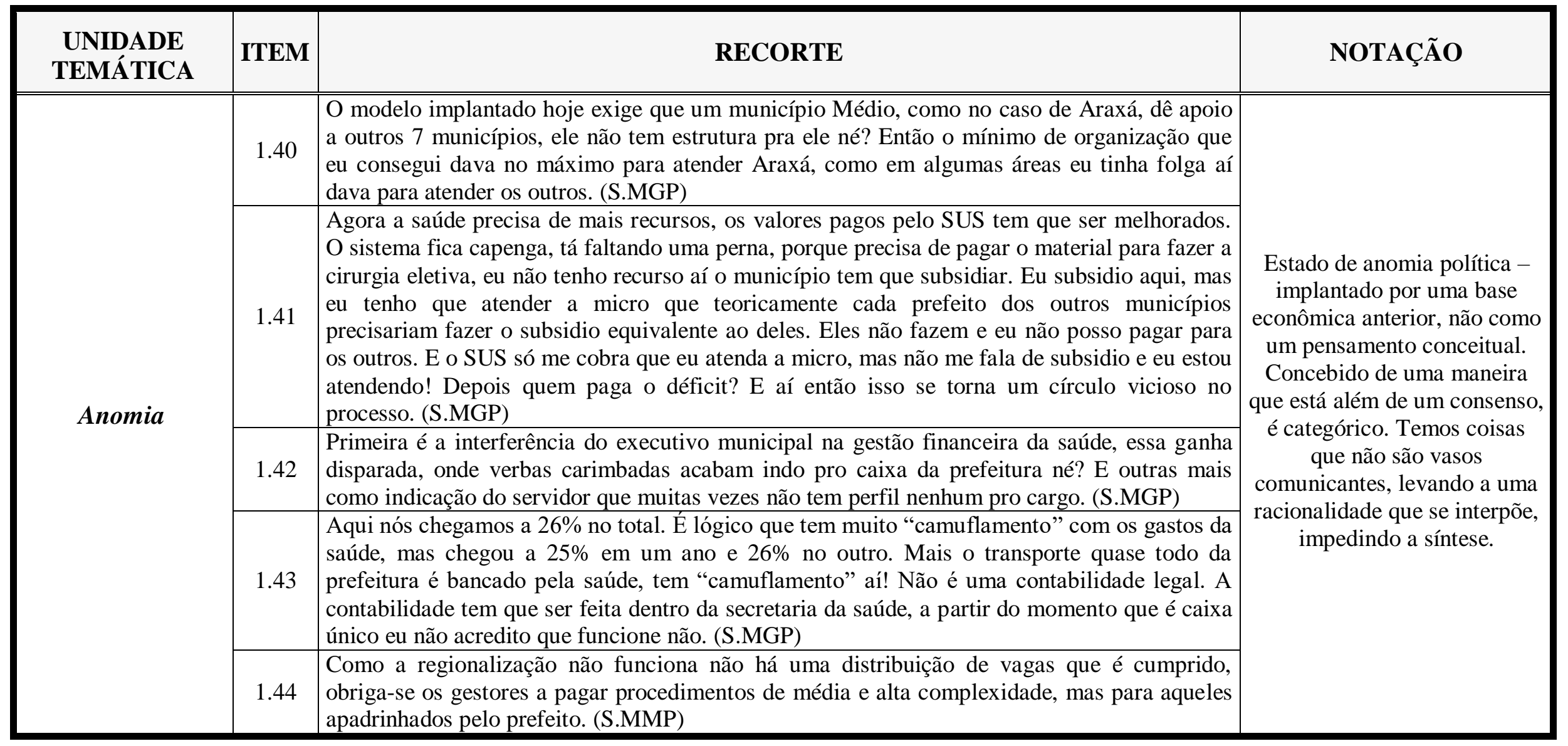


APÊNDICE D - Recortes, unidades temáticas e notações relacionadas ao conteúdo das entrevistas analisadas. Perspectivas dos Secretários Municipais de Saúde (Gestores do Sistema Único de Saúde - SUS) - Síntese final.

Quadro 11. Continuação - Unidades temáticas relacionadas à Categoria 1 - Racionalidades do Sistema Único de Saúde

\begin{tabular}{|c|c|c|c|}
\hline $\begin{array}{c}\text { UNIDADE } \\
\text { TEMÁTICA }\end{array}$ & ITEM & RECORTE & NOTAÇÃO \\
\hline Anomia & 1.45 & $\begin{array}{l}\text { Vinha à ordem do prefeito: "é pra fazer". Na parte de oftalmologia também eu paguei muita } \\
\text { cirurgia de catarata, mesmo falando assim: prefeito, nós temos campanha, vamos aguardar! } \\
\text { Era assim: "Não! Não pode esperar". E assim! O paciente vinha com o pedido de cirurgia de } \\
\text { um consultório particular, eu dizia para o prefeito: mas tem outro médico que faz por um } \\
\text { preço melhor. E ele dizia: "não! Mais é o médico dele e ele, e ele pediu tanto", então tinha que } \\
\text { pagar. (S.MMP) }\end{array}$ & $\begin{array}{l}\text { Estado de anomia política - } \\
\text { implantado por uma base } \\
\text { econômica anterior, não como } \\
\text { um pensamento conceitual. } \\
\text { Concebido de uma maneira } \\
\text { que está além de um consenso, } \\
\text { é categórico. Temos coisas } \\
\text { que não são vasos } \\
\text { comunicantes, levando a uma } \\
\text { racionalidade que se interpõe, } \\
\text { impedindo a síntese. }\end{array}$ \\
\hline
\end{tabular}


APÊNDICE D - Recortes, unidades temáticas e notações relacionadas ao conteúdo das entrevistas analisadas. Perspectivas apontadas pelos usuários Conselheiros Municipais de Saúde sobre o Sistema Único de Saúde (SUS) - Síntese final.

Quadro 12. Unidades temáticas relacionadas à Categoria 2 - Racionalidades do Controle Social

\begin{tabular}{|c|c|c|c|}
\hline $\begin{array}{l}\text { UNIDADE } \\
\text { TEMÁTICA }\end{array}$ & ITEM & RECORTE & NOTAÇÃO \\
\hline \multirow{6}{*}{$\begin{array}{l}\text { A crise de } \\
\text { Identidade }\end{array}$} & 2.1 & $\begin{array}{l}\text { Nossa, eu me tornei conselheira, através da minha luta, que eu tenho um filho especial. Então! } \\
\text { Como eu não tinha um apoio de ninguém, vamos dizer assim né? Orientação de saúde, o } \\
\text { serviço de saúde não me apresentava apoio até então! Foi através dessa minha corrida né? } \\
\text { Com o meu filho, com as minhas buscas né? (C.MGP) }\end{array}$ & \multirow{6}{*}{$\begin{array}{l}\text { Demonstra identidade com o } \\
\text { poder burocrático. } \\
\text { Afastamento de suas bases. } \\
\text { Esquecimento da memória da } \\
\text { luta de classes. }\end{array}$} \\
\hline & 2.2 & $\begin{array}{l}\text { Então! Como é que ele ia conseguir os tratamentos que ele consegue pra esposa dele se ele } \\
\text { não tivesse no conselho? Eu falei - "como cidadão, pelo seu direito natural". Isso não é justo! } \\
\text { Muitas outras pessoas estão no conselho e usam dessa situação do conselho pra arrumar } \\
\text { emprego pra filho, pra parente, isso é natural, isso acontece lá e aqui em menor grau, vamos } \\
\text { dizer assim. (C.MGP) }\end{array}$ & \\
\hline & 2.3 & $\begin{array}{l}\text { Então! Tem um grupo de conselheiros que é conselheiro de reunião, eles vão todo mês na } \\
\text { reunião, mas no dia a dia eles não fazem nada, e é um número muito grande, infelizmente. } \\
\text { (C.MGP) }\end{array}$ & \\
\hline & 2.4 & $\begin{array}{l}\text { Se a lei tá aqui, não é cumprida e eu não cobro, no direito isso tem um nome que é aceitação } \\
\text { tácita, eu não te perturbo, você não me perturba e nós ficamos no zero a zero. (C.MGP) }\end{array}$ & \\
\hline & 2.5 & $\begin{array}{l}\text { Porque tem aquela situação, arruma tudo quanto é parafernália e põe pro conselheiro analisar. } \\
\text { (C.MGP). }\end{array}$ & \\
\hline & 2.7 & $\begin{array}{l}\text { Tem muita demanda de urgência não programada, vamos dizer assim, urgência da secretaria } \\
\text { que deixavam "acontecer" e levavam pro conselho aprovar correndo. Então isso gerava um } \\
\text { transtorno, e às vezes a gente pedia vistas do conselho o que ficava meio complicado. } \\
\text { (C.MGP) }\end{array}$ & \\
\hline
\end{tabular}


APÊNDICE D - Recortes, unidades temáticas e notações relacionadas ao conteúdo das entrevistas analisadas. Perspectivas apontadas pelos usuários Conselheiros Municipais de Saúde sobre o Sistema Único de Saúde (SUS) - Síntese final.

Quadro 13. Continuação - Unidades temáticas relacionadas à Categoria 2 - Racionalidades do Controle Social

\begin{tabular}{|c|c|c|c|}
\hline $\begin{array}{c}\text { UNIDADE } \\
\text { TEMÁTICA }\end{array}$ & ITEM & RECORTE & NOTAÇÃO \\
\hline \multirow{2}{*}{$\begin{array}{l}\text { A crise de } \\
\text { Identidade }\end{array}$} & 2.8 & $\begin{array}{l}\text { Como se diz, o que ficar, assim, aprovado lá é o que a gente faz né. E não tem, assim, um que } \\
\text { vem aqui reclama alguma coisa, que já sai de lá decidido. (C.MPP) }\end{array}$ & \multirow{2}{*}{$\begin{array}{l}\text { Demonstra identidade com o } \\
\text { poder burocrático. } \\
\text { Afastamento de suas bases. } \\
\text { Esquecimento da memória da } \\
\quad \text { luta de classes. }\end{array}$} \\
\hline & 2.11 & $\begin{array}{l}\text { Agora! A secretaria de saúde nunca nos negou a prestar informações e fornecer técnicos que } \\
\text { nos ajudem a pensar, mas quando tem pessoas que tem nível de conhecimento suficiente a } \\
\text { coisa flui, quando não tem eles dirigem. Então os técnicos que vem nos apoiar pra esclarecer a } \\
\text { situação, vem muito vinculado, eles vem direcionando tudo aquilo pra ajeitar, não vem dar um } \\
\text { parecer isolado. (C.MGP) }\end{array}$ & \\
\hline
\end{tabular}


APÊNDICE D - Recortes, unidades temáticas e notações relacionadas ao conteúdo das entrevistas analisadas. Perspectivas apontadas pelos usuários Conselheiros Municipais de Saúde sobre o Sistema Único de Saúde (SUS) - Síntese final.

Quadro 14. Continuação - Unidades temáticas relacionadas à Categoria 2 - Racionalidades do Controle Social

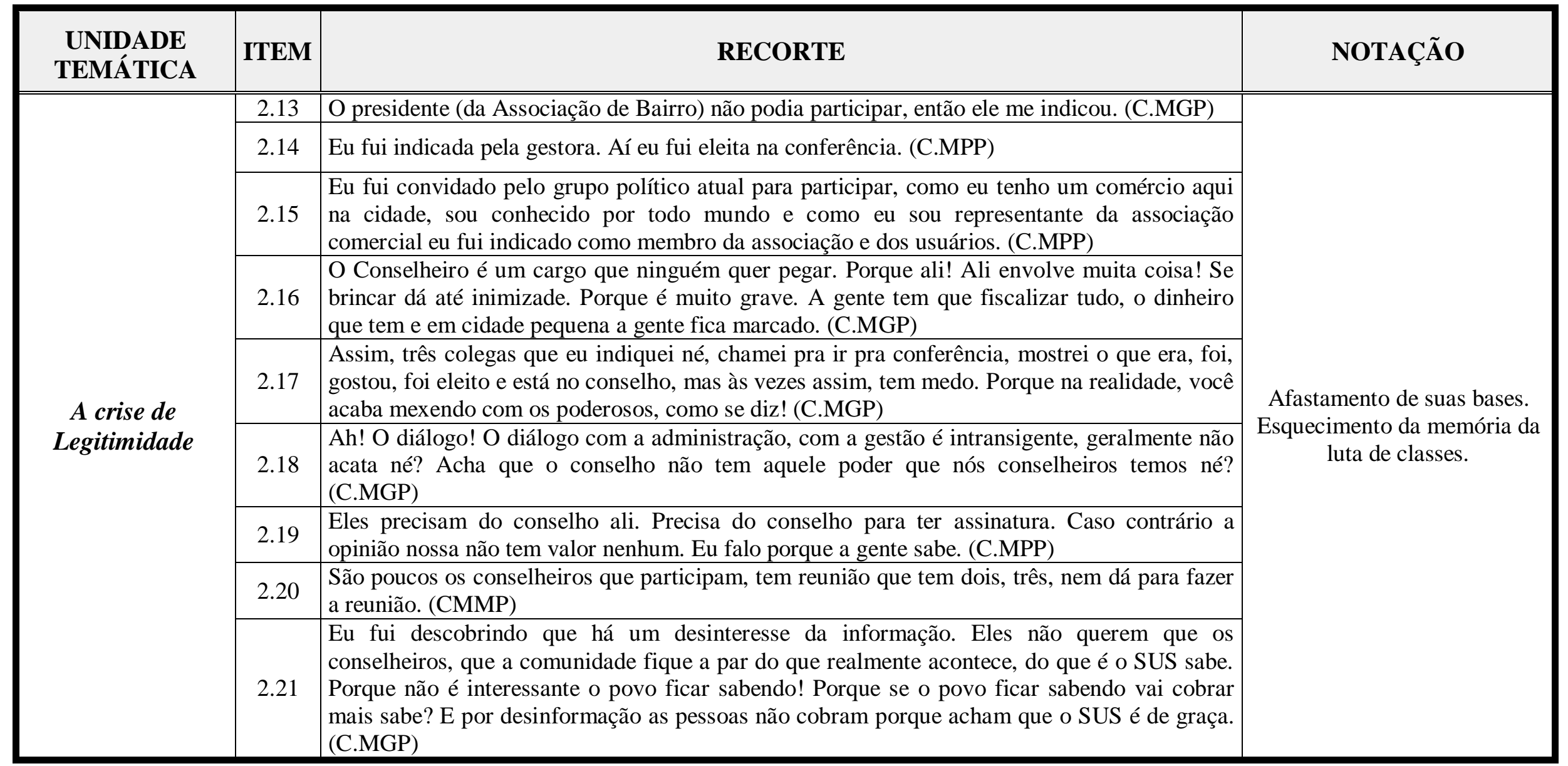


APÊNDICE D - Recortes, unidades temáticas e notações relacionadas ao conteúdo das entrevistas analisadas. Perspectivas apontadas pelos usuários Conselheiros Municipais de Saúde sobre o Sistema Único de Saúde (SUS) - Síntese final.

Quadro 15. Continuação - Unidades temáticas relacionadas à Categoria 2 - Racionalidades do Controle Social

\begin{tabular}{|c|c|c|c|}
\hline $\begin{array}{c}\text { UNIDADE } \\
\text { TEMÁTICA }\end{array}$ & ITEM & RECORTE & NOTAÇÃO \\
\hline \multirow{4}{*}{$\begin{array}{l}\text { A crise de } \\
\text { Legitimidade }\end{array}$} & 2.22 & $\begin{array}{l}\text { A maioria dos gestores simplesmente estão pendurados em um cargo político certo? E não } \\
\text { tem interesse na continuidade de abertura, de avanço no atendimento do usuário. (C.MMP) }\end{array}$ & \multirow{4}{*}{$\begin{array}{l}\text { Afastamento de suas bases. } \\
\text { Esquecimento da memória da } \\
\text { luta de classes. }\end{array}$} \\
\hline & 2.24 & $\begin{array}{l}\text { A participação popular depende da vontade da gestão. Porque se a gestão quiser publicizar as } \\
\text { situações você consegue público. Se você não caminhar, porque não tem como o grupo de } \\
\text { conselheiros fazer as coisas acontecerem naturalmente. Se o governo quer levar a gente pra } \\
\text { uma reunião, então ele põe a público, faz um palanque, chama os trabalhadores, chama toda a } \\
\text { sociedade e tal e consegue mobilizar. Se ele não quer ele cala, ele calando fica só a gente na } \\
\text { vontade e no laço. Então depende muito da vontade da gestão. (C.MGP) }\end{array}$ & \\
\hline & 2.25 & $\begin{array}{l}\text { Tem a força desse coletivo né, porque um só pode até tentar e consegue alguma coisa né, mas } \\
\text { eu acho que no coletivo surge, surte mais efeito né. (C.MGP) }\end{array}$ & \\
\hline & 2.26 & $\begin{array}{l}\text { Eu acho assim, eu não digo principal, a responsabilidade do conselheiro ela é única. É em } \\
\text { defesa do SUS e dos usuários. Quer dizer que quando você está em defesa do SUS, você não } \\
\text { está sendo nem a favor e nem contra o gestor, nem contra governo, é o SUS. Você pega a } \\
\text { política pública do SUS que é o Sistema Único de Saúde e você tem que ter aquele } \\
\text { compromisso. E nos momentos, vamos dizer assim, como o conselho é cogestor, o } \\
\text { conselheiro vai se posicionar em favor de situações que beneficia a sua comunidade. (C.MGP) }\end{array}$ & \\
\hline
\end{tabular}


ANEXOS 

ANEXO A - Carta de autorização para reprodução de imagem da obra Grupo com Homem Doente (1958) de Candido Portinari.

FFCLRP - USP

IImo(a). Sr(a):: Edward Meirelles

Setor de Iconografia

Rio de Janeiro, 05 de dezembro de 2014.

\title{
CARTA PADRÃO DE AUTORIZAÇÃO
}

Ref.: Reprodução de obra de Candido Portinari.

Prezado (a) Senhor (a):

Vimos pela presente informar a $\mathrm{V}$. Sa. que a autorização solicitada para reproduzir as obras de Candido Portinari descritas abaixo, em miolo de livro didático Gestão do Sistema de Saúde: um Estudo em Nove Municípios do Triângulo Mineiro, de autoria de Edward Meirelles, será concedida para publicação na forma impressa e digital, mediante as seguintes condições:

1 - Informação completa dos dados técnicos das obras a serem reproduzidas:

\author{
Candido Portinari \\ Grupo com Homem Doente \\ 1958 \\ FCO: 1689 \\ CR: 4352 \\ Desenho a lápis de cor / papel \\ $27 \times 38 \mathrm{~cm}$
}

2 - O Projeto Portinari se dispõe a, sem ônus adicional, rever o texto que acompanha a imagem autorizada, no que tange à exatidão das datas, nomes, dados técnicos e factuais, baseado no seu acervo de quase 5 mil obras e 30 mil documentos, resultado de um trabalho dedicado ao levantamento, catalogação e pesquisa sobre a vida, obra e época de Portinari, que teve início em 1979. Asseguramos ao autor/editor a mais estrita confidencialidade quanto aos textos eventualmente submetidos à nossa atenção.

3 - A presente autorização é concedida a titulo gratuito, podendo ser renovada.

4 - Que seja utilizada, preferencialmente, a imagem catalogada no acervo do Projeto Portinari, visando assegurar o máximo de fidelidade cromática e geométrica à reprodução aqui solicitada. 
Favor não utilizar imagem escaneada de livro, revista, ou qualquer tiragem em off-set, para evitar o efeito denominado Moiré, que afeta a qualidade da reprodução.

Parágrafo Único - A presente autorização está condicionada à comprovação do depósito do valor indicado no item 3 , através do envio do comprovante, pelo e-mail elizaseoud@portinari.org.br.

5 - Doação de 02 exemplares para Projeto Portinari e 01 exemplar para João Candido Portinari, a serem enviados para a Associação Cultural Candido Portinari, Rua Marquês de São Vicente, 225, sala 2, térreo, Gávea, Rio de Janeiro - RJ, CEP 22451-900

6 - Créditos dos direitos autorais para João Candido Portinari: Reprodução autorizada por João Candido Portinari.

7 - Créditos das imagens (cromo ou imagem digital) para o Projeto Portinari: Imagem do acervo do Projeto Portinari.

8 - Aprovação do layout da peça (pode ser enviada por e-mail, para agilizar o procedimento, para elizaseoud@portinari.org.br)

A presente autorização deve ser interpretada restritivamente, abrangendo tão somente a hipótese nela tratada. Na hipótese de futuras edições e/ou revisões da mencionada publicação, nova autorização deverá ser solicitada, elegendo-se o foro da cidade do Rio de Janeiro para dirimir quaisquer dúvidas oriundas da presente.

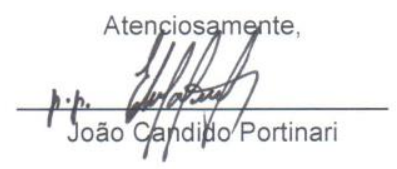

De acordo: assinatura e qualificação do representante legal da solicitante 
ANEXO B - Parecer de aprovação do comitê de ética em pesquisa da Faculdade de Filosofia,

Ciências e Letras de Ribeirão Preto da Universidade de São Paulo

Universidade de São Paulo
FFGLLP
Of.CEtP/FFCLRP-USP/169/-js|

Ribeirão Preto, 19 de dezembro de 2011

Prezado Pesquisador,

Comunicamos a V. Sa. que o trabalho intitulado "GESTÃo do SISTEMA ÚNICO de SAÚde: UM ESTUdo EM NOVE MUNICIPIOS do TRIÂNGULO MINEIRO" foi analisado pelo Comitê de Ética em Pesquisa da FFCLRP-USP, em sua 103 Reunião, realizada em 15.12.11, e enquadrado na categoria: APROVADO, de acordo com o Processo CEP-FFCLRP n 619/2011 - 2011.1.2526.59.2.

\section{Atenciosamente,}

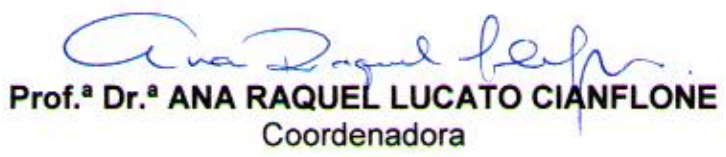

Ao Senhor

Edward Meirelles de Oliveira

Doutorando do Programa de Pós-Graduação em Psicologia da FFCLRP - USP

Com cópia para o orientador:

Prof. Dr. Marco Antonio de Castro Figueiredo

Docente do Departamento de Psicologia da FFCLRP - USP

CEP - Comitê de Ética em Pesquisa da FFCLRP

Fone: (16) $3602-4811$

Fax: (16) 3633-2660 (direto) ou 3633-5015

Avenida Bandeirantes, 3900 - bloco 3 - sala 16 - 14040-901 - Ribeirăo Preto - SP - Brasil

Homepage: http //www .ffcirp. usp.br - e-mail: coetp@ffclip.usp.br 